UNIVERSIDADE DE SÃO PAULO - FACULDADE DE ARQUITETURA E URBANISMO EVY HANNES

Infraestrutura verde como estratégia para comunidades ecológicas: um plano para a Vila Amélia

São Paulo | 2018 


\section{Infraestrutura verde como estratégia para comunidades ecológicas: um plano para a Vila Amélia}

EXEMPLAR REVISADO E ALTERADO EM RELAÇÃO À VERSÃO ORIGINAL, SOB RESPONSABILIDADE DO(A) AUTOR(A) E ANUÊNCIA DO(A) ORIENTADOR(A). A versão original, em formato digital, ficará arquivada na Biblioteca da Faculdade. São Paulo, 24 de Janeiro de 2018.

Dissertação apresentada à Faculdade de Arquitetura e Urbanismo da Universidade de São Paulo para obtenção do título de Mestre em Arquitetura e Urbanismo. Área de concentração: Paisagem e Ambiente.

Orientadora: Prof.a. Dra. Maria de Assunção Ribeiro Franco 
Autorizo a reprodução e divulgação total ou parcial deste trabalho, por qualquer meio convencional ou eletrônico, para fins de estudo e pesquisa, desde que citada a fonte.

Catalogação na Publicação

Serviço Técnico de Biblioteca

Faculdade de Arquitetura e Urbanismo da Universidade de São Paulo

Hannes, Evy

Infraestrutura verde como estratégia para

comunidades ecológicas: um plano para a Vila Amélia /

Evy Hannes; orientadora Maria de Assunção Ribeiro

Franco. - São Paulo, 2018

$190 \mathrm{f}$.

Dissertação (Mestrado) - Faculdade de Arquitetura e Urbanismo da Universidade de são Paulo. Área de concentração: Paisagem e Ambiente

1. Planejamento Ambiental. 2. Infraestrutura Verde. 3. Bairros Ecológicos. I. Franco, Maria de Assunção Ribeiro, orient. II. Título.

Elaborada eletronicamente através do formulário disponível em: $\langle$ http://www.fau.usp.br/fichacatalografica/ $>$ 
Evy Hannes

INFRAESTRUTURA VERDE COMO ESTRATÉGIA PARA COMUNIDADES ECOLÓGICAS:

UM PLANO PARA A VILA AMÉLIA

Dissertação apresentada à Faculdade de Arquitetura e Urbanismo da Universidade de São Paulo para obtenção do título de Mestre em Arquitetura e Urbanismo.

Aprovado em:

\section{Banca Examinadora}

Prof. Dr. Instituição:

Julgamento: Assinatura:

Prof. Dr. Instituição:

Julgamento: Assinatura:

Prof. Dr. Instituição:

Julgamento: Assinatura:

Prof. Dr. Instituição:

Julgamento: Assinatura: 
Aos meus pais, Howard e Mariza (in memorian), que desde cedo me mostraram o valor do estudo.

Ao meu companheiro, Rodrigo, pelo apoio e entendimento do momento de entrega.

Ao meu amado filho Gael, que acompanhou o desenvolvimento desse trabalho dentro e fora do ventre. Que lhe sirva como inspiração. 


\section{Agradecimentos}

À orientadora prof.a. Dra. Maria de Assunção Ribeiro Franco por ter despertado o interesse na pesquisa ambiental e pelo constante incentivo e apoio nessa jornada do desenvolvimento do saber.

Aos professores Catharina Pinheiro Cordeiro dos Santos Lima, Eugênio Quiroga, Caio Boucinhas, Paulo Pellegrino e todos os professores da Universidade de São Paulo que participaram desse prazeroso processo de aprendizado e aperfeiçoamento. Ao professor José Guilherme Schutzer que se mostrou sempre muito atencioso na conferência dos mapas relativos ao seu método de análise, por seus valiosos comentários na banca de qualificação.

Aos queridos amigos feitos durante essa jornada, que além de dividir angústias, ansiedades, risadas e muitos cafés no Benjamim também se tornaram companheiros no caminho acadêmico. Um obrigada especial à Juliana e Sarah que contribuíram com a revisão de algumas partes dessa pesquisa.

A todos os amigos que direta ou indiretamente contribuíram para a conclusão desse trabalho.

Ao meu esposo Rodrigo, que hoje é quase um expert no tema dessa pesquisa e ao meu pequeno Gael. Cada sorriso seu funcionou como um enorme incentivo! 
É nossa obra o aproveitamento dos montes e das planícies; os rios e os lagos estão em nosso poder, somos nós que semeamos os cereais, que plantamos as árvores, que fecundamos os terrenos com obras de canalização e de irrigação, que detemos, que canalizamos, que desviamos o curso dos rios, que nos esforçamos, em última análise, para construir no seio da natureza uma espécie de segunda natureza.

Marco Túlio Cícero, De natura deorum, 45 a.C. 


\section{RESUMO}

HANNES, Evy. Infraestrutura verde como estratégia para comunidades ecológicas: um plano para a Vila Amélia. 2017. 201p. Dissertação (Mestrado) - Faculdade de Arquitetura e Urbanismo, Universidade de São Paulo, São Paulo, 2017.

Orientadora: Prof. ${ }^{a}$. Dra. Maria de Assunção Ribeiro Franco

A infraestrutura verde surge como ferramenta capaz de transformar o espaço urbano e reconectar o homem com os espaços verdes da cidade. Coloca os elementos naturais como provedores de benefícios fundamentais à vida e os processos ecológicos como estruturadores de um novo pensamento que usa os sistemas fluviais e os fragmentos verdes como espinha dorsal e conectores da malha urbana. Trabalhando em rede, prevê espalhar esses benefícios a pequenas e grandes escalas, melhorando a qualidade ambiental e a vida nas cidades. A dissertação explora a possibilidade de usar a infraestrutura verde como ferramenta para criação de comunidades ecológicas e através de estudos de casos de bairros ecológicos e ecovilas nos Estados Unidos e Europa busca as boas práticas já implantadas nas mesmas. A pesquisa foca na região norte de São Paulo, na bacia hidrográfica do córrego do Índio e na Vila Amélia, agrupamento residencial inserido em meio à área do Parque Estadual Alberto Lofgren, o Horto Florestal. A área foi escolhida por apresentar contexto único e grande potencial de transformação através da aplicação de princípios ecológicos. Para finalizar, o estudo propõe algumas diretrizes que podem contribuir para a criação de uma ecocomunidade que respeite suas características e processos naturais, a capacidade de suporte de seus ecossistemas e que contribua para a construção de uma cidade mais equilibrada, sustentável e resiliente.

Palavras-chave: Infraestrutura verde, Planejamento ambiental, Bairros ecológicos, Ecovilas, Córrego do Índio, Vila Amélia. 


\begin{abstract}
HANNES, Evy. Green infrastructure as a strategy for ecological communities: a plan for Vila Amélia. 2017. 201p. Dissertation (Academic Master Degree) College of Architecture and Urbanism, University of São Paulo, São Paulo, 2017.
\end{abstract}

Dissertation Advisor: Prof.a. Dra. Maria de Assunção Ribeiro Franco

The green infrastructure emerges as a tool capable of transforming the urban space and reconnecting man with cities green spaces. It places natural elements as providers of fundamental benefits to life and ecological processes as builders of a new thinking that uses river systems and green fragments as the backbone and connectors of the urban fabric. Working in a network, it plans to spread these benefits to small and large scales, improving environmental quality and city life. The dissertation explores the possibility of using green infrastructure as a tool to create ecological communities and through case studies of econeighborhoods and ecovillages in the United States and Europe seeks their good practices. The research focuses on the northern region of São Paulo, the stream basin of Indio stream and Vila Amélia, a residential group placed in the middle of the area of the Alberto Lofgren State Park, the Horto Florestal. The area was chosen because it presents an unique context and great transformation potential through the application of ecological principles. To conclude, the study proposes some guidelines that can contribute to the creation of an ecocommunity that respects its natural characteristics and processes, the support capacity of its ecosystems and that contributes to the construction of a more balanced, sustainable and resilient city.

Key-words: Green infrastructure, Environmental planning, Ecological neighborhoods, Ecovillages, Índio stream, Amélia Village. 


\section{LISTA DE FIGURAS}

Figura 01. Larguras recomendadas de corredores ecológicos ................ 48

Figura 02. Dinâmica de fluxos ecológicos dos corpos d'água .................. 49

Figura 03. Cinco funções dos corredores de biodiversidade .................... 50

Figura 04. Forma ideal de uma mancha ............................................ 52

Figura 05. Modelo de bairro de Clarence Perry …............................. 78

Figura 06. Modelo de bairro da DPZ ................................................. 78

Figura 07. Modelo de bairro de Douglas Farr …….................................... 79

Figura 08. Plano geral de Vauban .................................................... 83

Figura 09. Linha de VLT de Vauban .................................................. 84

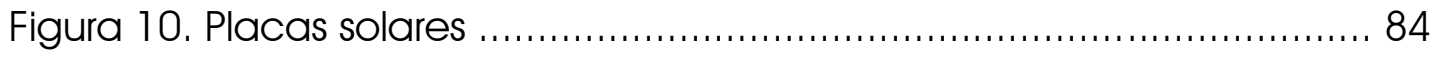

Figura 11. Área de lazer interior às quadras das cohousings .................... 85

Figura 12. Biovaletas de drenagem natural ........................................ 85

Figura 13. Pequeno parque entre edifícios residenciais ........................... 85

Figura 14. Ciclista nas ruas de Vauban ........................................... 86

Figura 15. Woonerf com sua característica sinalização em azul ............... 86

Figura 16. Plano geral da proposta de intervenção para o Ecobairro de

Southwest, Washington D.C ......................................................... 88

Figura 17. Cenário comparativo antes e depois da implantação do plano geral para o Ecobairro de Southwest

Figura 18. Perspectiva de corte da rua mostrando fachada ativa,

infraestrutura verde e ciclovia

Figura 19. Perspectiva mostrando terminal intermodal previsto no projeto 90

Figura 20. Plano de captação de energia solar na escala da quadra ..... 90

Figura 21. Plano de captação de águas pluviais .................................... 90

Figura 22. Plano de infraestrutura verde ............................................ 91

Figura 23. Jardins de chuva responsáveis pela captação, filtragem e escoamento das águas pluviais .......................................................... 91

Figura 24. Mapa de localização de espaços e atividades em Findhorn .. 97

Figura 25. Máquina viva 
Figura 26. Hélices de energia eólica ............................................ 98

Figura 27. Jardins comunitários ......................................................... 98

Figura 28. Casas com placas solares no telhado ……............................ 98

Figura 29. Casa construída com madeira de barris de whiskey ................ 99

Figura 30. Casa construída com madeira e tratamento térmico .............. 99

Figura 31. Panorama de uma rua em Findhorn ........................................ 99

Figura 32. Panorama de uma rua em Findhorn ..................................... 100

Figura 33. Plano geral do projeto …............................................... 102

Figura 34. Imagem aérea do Google ............................................ 102

Figura 35. Esquema mostrando as ligações de pedestres e ciclovias em meio às áreas verdes

Figura 36. Imagem do Google mostrando o momento em que uma via de pedestres encontra a rua local, bem como a arborização das vias locais .................................................................................... 103

Figura 37. Cinturão voltado à plantação de frutas e hortaliças .............. 104 Figura 38. Área verde com valeta e bacia de detenção ........................ 105 Figura 39. Biovaleta de pedra e valeta gramada para drenagem de águas pluviais ............................................................................... 105

Figura 40. Crianças brincam em área verde onde é possível ver o sistema de drenagem natural .......................................................... 106

Figura 41. Área destinada à produção de alimentos .............................. 106

Figura 42. Jardim de chuva na cidade de Seattle ................................ 119

Figura 43. Biovaleta na cidade de Los Angeles ..................................... 119

Figura 44. Lagoa pluvial em Frieburg …......................................... 120

Figura 45. Córrego renaturalizado ........................................................... 120

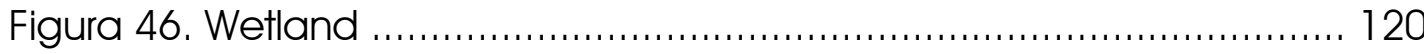

Figura 47. Teto verde com horta ................................................. 120

Figura 48. Parede verde próxima ao minhocão, São Paulo ……............. 120

Figura 49. Localização da bacia hidrográfica do córrego Cabuçu de Baixo

Figura 50. Bacia hidrográfica do córrego Cabuçu de Baixo e suas 
sub-bacias constituintes

Figura 51. Bacia do Guaraú e sub-bacia do Índio

Figura 52. Sub-bacia do Índio, Vila Amélia, Horto Florestal e limite de subprefeituras em laranja

Figura 53. Mapa de distribuição da vegetação do Atlas Ambiental do Município de São Paulo com demarcação da bacia hidrográfica do córrego do Índio

Figura 54. Mapa da Vegetação Significativa do Município de São Paulo com demarcação da bacia hidrográfica do córrego do índio

Figura 55. Córrego do Índio correndo a céu aberto, mas isolado por Grade do contato com os usuários do Parque do Horto Florestal

Figura 56. Córrego do Índio correndo em calha de concreto em viela entre residências

Figura 57. Córrego do Índio correndo em calha de terra, não natural, entre residências

Figura 58. Possível localização de nascente na esquina das Ruas Torre da Alfândega e Said Saad

Figura 59. Marcas de infiltração nos muros do edifício e água corrente no passeio na esquina das Ruas Torre da Alfândega e Said Saad

Figura 60. Possível localização de nascente na curva da R. Dr. Alcides

Cintra Bueno Filho

Figura 61. Foto da área da possível localização de nascente na curva Da R. Dr. Alcides Cintra Bueno Filho

Figura 63. Mapa da topografia da bacia hidrográfica do córrego do Índio

Figura 64. Mapa da topografia mostrando as declividades da bacia hidrográfica do córrego do Índio

Figura 65. Mapa mostrando a Vila Amélia inserida em meio à vegetação do Horto Florestal

Figura 66. Mapa mostrando a bacia do córrego Índio e sua composição geológica 
Figura 67. Seção geomorfológica da Serra da Cantareira 140

Figura 68. Mapa mostrando a bacia do córrego do Índio sobre o Mapa Sara Brasil

Figura 69. Mapa mostrando a bacia do córrego do Índio e suas unidades climáticas urbanas

Figura 70. Mapa mostrando a bacia do córrego Índio sobre mapa das Ilhas de Calor

Figura 71. Mapa mostrando o zoneamento ambiental do córrego do Índio

Figura 72. Foto de Rua na Vila Amélia que faz limite com a vegetação do Horto Florestal

Figura 73. Foto de Rua na Vila Amélia mostrando o visual da vegetação do Horto Florestal ao fundo

Figura 74. Bacia do córrego do Índio sobre imagem Sara Brasil de 1930

Figura 75. Bacia do córrego do Índio sobre imagem de 1943

Figura 76. Mapa das Macrozonas do Plano Diretor da cidade de São

Paulo

Figura 77. Mapa das Macroáreas do Plano Diretor da cidade de São

Paulo 153

Figura 78. Padrão de ocupação residencial da Vila Amália 154

Figura 79. Padrão de ocupação residencial da Vila Amália 154

Figura 80. Imagem do Geosampa - uso e ocupação do solo 155

Figura 81. Parte de residência transformada em bar e loja de conveniências 155

Figura 82. Lote com residência em situação precária 155

Figura 83. Residência padrão médio-alto 155

Figura 84. Residência padrão médio-alto 155

Figura 85. Mapa de zoneamento 156

Figura 86. Mapa de densidade demográfica

Figura 87. Áreas de vulnerabilidade social 
Figura 88. Núcleo de lazer do Horto Florestal com acesso pela Vila Amália

Figura 89. Núcleo de lazer Arboreto Vila Amália do Horto Florestal com acesso pela Vila Amélia

Figura 90. Despejo de esgoto residencial no córrego do índio

Figura 91. Despejo de esgoto residencial no córrego do índio 159

Figura 92. Zoneamento ambiental do córrego do Índio 162

Figura 93. Plano de infraestrutura verde para a bacia do córrego do Índio

Figura 94. Plano de infraestrutura verde para a bacia do córrego do Índio

Figura 95. Zoneamento ambiental da Vila Amélia

Figura 96. Plano de infraestrutura verde para a Vila Amélia 173

Figura 97. Corte de rua que será transformada em woonerf 174

Figura 98. Corte ilustrando o cenário pretendido com a implantação do parque fluvial do córrego do Índio

\section{LISTA DE TABELAS}

Tabela 01. Tabela mostrando funções, processos e seus respectivos serviços ecossistêmicos 64

Tabela 02. Lista de parâmetros e princípios do urbanismo ecológico ...... 75 Tabela 03. Tabela dos princípios do urbanismo ecológico mostrando os pontos atendidos no projeto de Vauban

Tabela 04. Tabela dos princípios do urbanismo ecológico mostrando os pontos atendidos no projeto do Southwest District

Tabela 05. Tabela dos princípios do urbanismo ecológico mostrando os pontos atendidos no projeto de Findhorn

Tabela 06. Tabela dos princípios do urbanismo ecológico mostrando os pontos atendidos no projeto de Village Davis 
Tabela 08. Tabela dos princípios do urbanismo ecológico mostrando sua ligação com conceitos de infraestrutura verde e sua utilização nos estudos de caso.

\section{LISTA DE ABREVIATURAS E SIGLAS}

AM - Avaliação Ecossistêmica do Milênio

AMOVA - Associação de moradores da Vila Amélia

ASLA - Associação Americana dos Arquitetos Paisagistas

BID - Banco Interamericano de Desenvolvimento

CAEM - Conselho de Avaliação Ecossistêmica do Milênio

CBD - Convenção sobre a Diversidade Biológica

CETESB - Companhia Ambiental do Estado de São Paulo

DAEE - Portal do Departamento de Águas e Energia Elétrica do Estado de São Paulo

DEPAVE - Departamento de Parques e Áreas Verdes

FAU - Faculdade de Arquitetura e Urbanismo da Universidade de São Paulo

GEN - Global Ecovillage Network

MAB - Programa Homem e Biosfera

ODM - Objetivos de Desenvolvimento do Milênio

ONU - Organização das Nações Unidas

PDE - Plano Diretor Estratégico da cidade de São Paulo

UNCED - Conferência das Nações Unidas para o Meio Ambiente e Desenvolvimento

UNESCO - Organização das Nações Unidas para a Educação, Ciência e Cultura

WECD - Comissão Mundial sobre Meio Ambiente e Desenvolvimento 


\section{SUMÁRIO}

INTRODUÇÃO

CAPÍTULO 1. ○ PLANEJAMENTO DA PAISAGEM ................................... 24

1. 1. A arquitetura da paisagem desenhando o espaço livre ................... 27

1.2. Desenho ambiental: respeito às dinâmicas naturais da paisagem ... 31

1.3. Ecologia e os processos da paisagem ..................................... 35

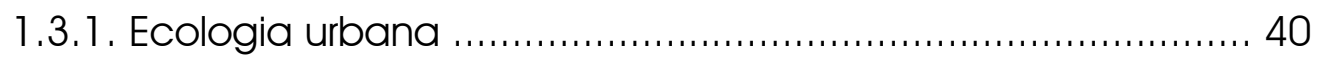

1.3.2. Ecologia da paisagem ....................................... 44

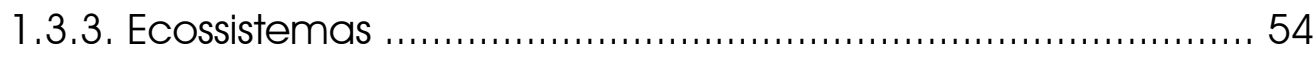

1.3.4. Senviços ecossistêmicos ........................................... 59

1.4. Desenvolvimento sustentável para a cidade resiliente ...................... 65

CAPÍTULO 2. ECOVILAS E BAIRROS ECOLÓGICOS $\ldots \ldots \ldots \ldots \ldots \ldots \ldots \ldots \ldots \ldots \ldots \ldots . \ldots$

2.1. O movimento do ecourbanismo .......................................... 71

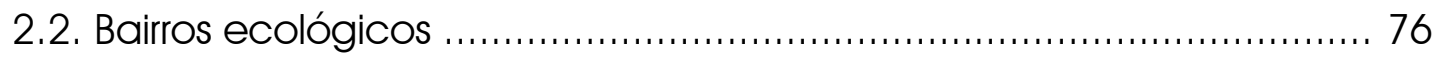

2.2.1. Definição de bairro ecológico ........................................ 76

2.2.2. Vauban - Freiburg (Alemanha) ..................................... 82

2.2.3. SW Ecodistrict - Washington D.C. (EUA) ............................ 87

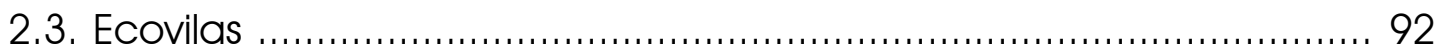

2.3. 1. Definição de Ecovila ................................................. 93

2.3.2. Findhorn Foundation - Forres (Escócia) ............................ 96

2.3.3. Village Holmes, Estados Unidos .................................. 101

CAPÍTULO 3. INFRAESTRUTURA VERDE COMO FERRAMENTA PARA O PLANEJAMENTO AMBIENTAL E ECOLÓGICO DA PAISAGEM ....................... 108

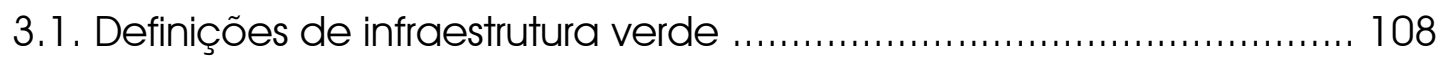

3.2. Princípios da Infraestrutura verde .......................................... 111 
3.3. Funções da Infraestrutura verde

3.3. 1. Ambiental: os serviços ecossistêmicos e a paisagem como máquina

3.3.2. Paisagística: a revalorização da paisagem

3.3.3. Social - urbana: rede de espaços livres e mobilidade sustentável

3.4. Paisagens naturais $x$ paisagens construídas

3.5. Escalas da infraestrutura verde

3.6. Infraestrutura verde como ferramenta potencial para comunidades ecológicas

PARTE II. ANÁLISE TERRITORIAL DA PAISAGEM: BACIA DO CÓRREGO DO ÍNDIO E VILA AMÉLIA

CAPÍTULO 4. CARACTERIZAÇÃO FíSICO AMBIENTAL DO TERRITÓRIO

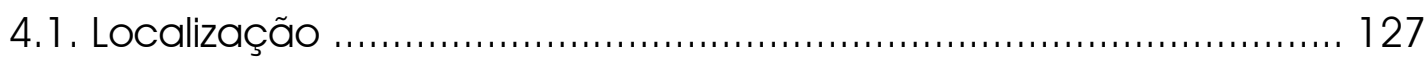

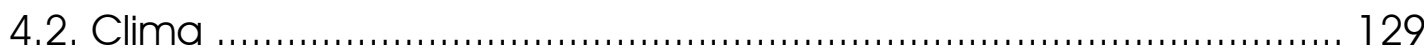

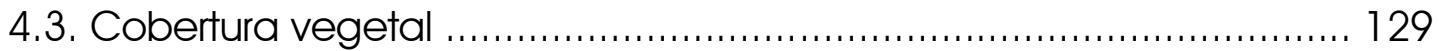

4.4. Nascentes e cursos d'água …............................................... 132

4.5. Geomorfologia e compartimentação da paisagem ...................... 136

4.6. Estrutura superficial ....................................................................... 139

4.7. Fisiologia da paisagem …................................................... 142

4.8. Zoneamento ambiental: potencialidades naturais e funções ambientais na bacia do córrego do Índio ........................................... 145

CAPÍTULO 5. CARACTERIZAÇÃO MORFOLÓGICA E URBANA DA OCUPAÇÃO: O CÓRREGO DO ÍNDIO E A VILA AMÉLIA ...................................................... 150

5.1. Histórico de ocupação …........................................................ 150

5.2. Usos e ocupação territorial ........................................................... 151

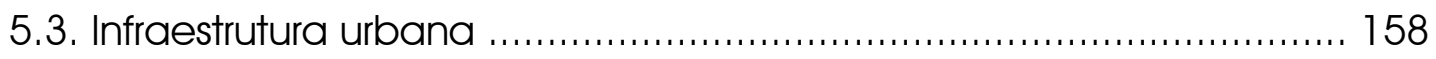


PARTE III. PLANO ECOLÓGICO PARA A BACIA DO ÍNDIO E PARA A VILA AMÉLIA

CAPITULO 6. DIRETRIZES DE INFRAESTRUTURA VERDE PARA A BACIA

DO CÓRREGO DO ÍNDIO

6. 1. Zoneamento urbano ambiental para a bacia do córrego do Índio 161 6.2. Plano de infraestrutura verde para a bacia do córrego do índio ..... 165

CAPÍTULO 7. DIRETRIZES DE INFRAESTRUTURA VERDE PARA A ECOVILA AMÉLIA

7.1. Zoneamento urbano ambiental para a Vila Amélia 170

7.2. Plano de infraestrutura verde para a Ecovila Amélia. 172 


\section{INTRODUCÃ̃O}

O crescimento acelerado pelo qual as grandes cidades passaram no último século e a impossibilidade dos governos municipais de acompanhar e fiscalizar de perto esse processo gerou graves consequências à produção do espaço urbano. Isso se reflete na qualidade dos serviços de infraestrutura e dos espaços públicos oferecidos aos seus moradores bem como nas transformações exercidas pelo homem na paisagem natural, muitas vezes extrapolando sua capacidade de suporte e alterando drasticamente e de forma irreversível suas dinâmicas naturais. O bem estar humano, a qualidade de vida e o desenvolvimento sustentável estão diretamente relacionados à gestão desses ecossistemas e dos serviços que fornecem.

O panorama atual das cidades, num contexto mundial, carece de intervenções urbanas que considerem a interdependência dos fenômenos biológicos, psicológicos, sociais e que sejam geridos por ferramentas do urbanismo ecológico. (CAEM, 2005; CAPRA, 1982). Em busca de melhores condições de vida e de maior contato e respeito com a natureza, a sociedade se articula na criação de ecovilas e ecocomunidades, o setor imobiliário produz, cada vez mais, empreendimentos com selos verdes, ditos sustentáveis. Governos locais buscam medidas para solucionar os conflitos derivados do eterno embate entre urbano e natural, aplicando soluções inovadoras e engenharia ambiental para mitigar alguns desses problemas e também prover melhor qualidade de vida.

É nesse cenário que a infraestrutura verde surge como instrumento de transformação do espaço, articulando desenho urbano e as características do espaço natural, suas dinâmicas e a capacidade de suporte dos ecossistemas. Coloca os sistemas de elementos naturais e áreas verdes como fornecedores de serviços ambientais fundamentais à vida dos seres humanos, espécies vegetais e animais e também como 
infraestrutura que mitiga impactos urbanos danosos à saúde e à vida nas cidades, provendo benefícios ecológicos, sociais, econômicos e contribuindo para a criação de comunidades mais vibrantes, equilibradas e resilientes.

A Vila Amélia e a bacia do córrego do Índio foram escolhidos como área de estudo, pois se apresentam como interessante oportunidade de pesquisa acerca da qualidade ambiental dos bairros situados nas bordas da cidade, próximas ao seu limite político e legislativo, mas não tão próximas dos limites da urbanização metropolitana. Tal configuração os coloca como área de urbanização consolidada, mas que apresenta ainda grandes áreas vegetadas, fragmentos de mata nativa, terrenos não construídos, córregos não canalizados, nascentes preservadas e proximidade com a matriz ecológica da Serra da Cantareira, o que the conferem grande interesse como área de estudos da ecologia da paisagem. O fato de a Vila Amélia estar localizada em meio à área do Parque Estadual Alberto Lofgren, o Horto Florestal, também realça seu valor e potencial como comunidade ecológica que possa servir de modelo a ser replicado em outras regiões da cidade.

Trata-se de uma zona de grande potencial paisagístico e ambiental onde suas particularidades não foram abordadas ainda de forma estrutural e assertiva. A grande motivação dessa pesquisa se expressa na intenção de fazer aflorar esse potencial e na possibilidade de estabelecer relações que propiciem a apreciação da paisagem e o convívio entre elementos urbanos e naturais de forma equilibrada, criando uma situação de qualidade ambiental e urbana traduzidas em qualidade de vida para os moradores da região.

Como objetivo geral desta pesquisa pretende-se desenvolver o estudo do conceito de infraestrutura verde, apoiado nas teorias de desenho ambiental e ecologia da paisagem, analisando a sua aplicabilidade ao bairro da Vila Amélia e sua potencialidade como ferramenta para a construção de uma comunidade ecológica. Como 
seus objetivos específicos, apontamos: o estudo da relação entre os conceitos de infraestrutura verde, desenho ambiental, ecologia da paisagem e ecologia urbana; a exploração do conceito de ecovilas e bairros ecológicos, suas características, fundamentos e diferenças relativas à escala; a análise da estrutura ambiental e urbana da Vila Amélia e bacia hidrográfica do córrego do Índio através da aplicação do método de leitura de José Guilherme Schutzer; a discussão da possibilidade de implantação de um sistema de infraestrutura verde na área analisada, bem como sua potencialidade como ferramenta para a formação de uma comunidade ecológica e a proposição de diretrizes para a bacia do córrego do Índio e para o bairro da Vila Amélia que auxiliem na construção de espaços mais sustentáveis e resilientes.

Este trabalho foi estruturado em três partes que se subdividem em sete capítulos. A primeira parte do trabalho tratará de toda a conceituação teórica que embasa a dissertação e que é necessária ao seu bom entendimento. Na parte 2 será dado enfoque à leitura da área estudada, a bacia hidrográfica do córrego do Índio e a Vila Amélia. Na última parte serão apresentadas as diretrizes de infraestrutura verde para a área estudada e que contribuirão para o desenvolvimento desses locais em espaços que funcionem em consonância com os processos naturais e que possam se desenvolver no caminho de formação de núcleos ecológicos e do desenvolvimento sustentável.

No capítulo 1 são colocados conceitos básicos ao planejamento da paisagem e ecologia que vão embasar o entendimento dos capítulos subsequentes. Começa com uma análise do conceito da arquitetura da paisagem, historicamente um dos primeiros nomes dados à arte de projetar os espaços livres e lidar com os elementos naturais e o território e desenvolve uma sequência de outros conceitos derivados deste ou que o complementam, traçando um panorama do desenvolvimento científico dessa arte. Inicia com um breve histórico do relacionamento entre homem e paisagem e mostra o desdobramento dos ideais do desenho ambiental, 
com seus fundamentos de respeito às dinâmicas naturais da paisagem. Na sequência parte para a colocação fundamental de sua relação com a ecologia e os processos da paisagem, abordando as teorias da ecologia urbana, ecologia humana e ecologia da paisagem. Explica o que são ecossistemas e serviços ecossistêmicos, conceitos muito importantes para $\mathrm{O}$ entendimento posterior das ideias relativas à infraestrutura verde. O capítulo finaliza com um estudo sobre a compreensão do desenvolvimento sustentável, sua ligação com os ecossistemas e com a criação de cidades mais resilientes.

No capítulo 2 são abordados os bairros e vilas ecológicas e analisados casos na Europa e América que abordem toda a diversidade de ideias envolvidas pelas práticas do ecourbanismo e que senvirá de base para o desenvolvimento das diretrizes do final desse projeto. Essa escala de conceituação foi escolhida, pois é a que mais se aproxima da área estudada nesse trabalho, a Vila Amélia, vila ou pequeno bairro situado na zona Norte da cidade de São Paulo. Aborda os fundamentos apontados pelos autores que mais se destacam nessa área de estudo bem como estudos de caso que possam contribuir para o entendimento desses conceitos e também evidenciar as boas práticas adotadas nos projetos já implantados ou ainda em desenvolvimento.

O capítulo 3 trata do tema central dessa dissertação, a infraestrutura verde. Nele será feita uma compilação dos conceitos de infraestrutura verde, serão colocados seus princípios mais importantes como a conexão, respeito ao contexto, seus benefícios às pessoas e à natureza. Serão salientadas suas funções principais como a ambiental, ligada ás questões de preservação e serviços ecossistêmicos, a paisagística que trata da composição da paisagem e a cívica, já que trata de espaços de grande valoração e utilização diversa pelos seus usuários. Coloca a questão dos espaços naturais e suas funções e dos elementos de infraestrutura verde totalmente construídos pelo homem, com base nos processos naturais e serviços ecossistêmicos, para gerar infraestrutura de alto desempenho que 
trabalhe a favor da cidade. Aborda a questão da multiescalaridade do conceito, que pode ser tratado em grandes planos nacionais bem como em elementos individuais em varandas de edifícios. Por fim, aborda a infraestrutura verde como ferramenta para a formação de comunidades ecológicas, usando como base os estudos abordados no capítulo 2.

O capítulo 4 desenvolve a análise física da área estudada dividindoa em duas escalas de análise: a bacia hidrográfica do córrego do Índio e a Vila Amélia. Serão identificadas as relações entre as dinâmicas físicas e ambientais do território e os processos ecológicos, mostrando como fatores como o clima, a vegetação e as águas se comportam em diferentes estruturas superficiais e compartimentos de paisagem. Como base metodológica será utilizado o livro Cidade e Meio Ambiente, do geógrafo José Guilherme Schutzer.

O capítulo 5 faz análise da forma urbana da área estudada, mantendo as escalas adotadas no capítulo anterior. Abordará as questões urbanas mais importantes para $\bigcirc$ entendimento do espaço como questões relativas à infraestrutura urbana, uso do solo e ocupação.

No capítulo 6 apresentamos o zoneamento ambiental urbano da bacia do córrego do Índio e as diretrizes de infraestrutura verde para a esse espaço. As diretrizes terão como base os conceitos de infraestrutura verde e planejamento da paisagem estudados nos capítulos anteriores, bem como o entendimento das dinâmicas da área estudada.

O capítulo 7 conclui o estudo desenvolvido nessa dissertação, apresentando as ferramentas da infraestrutura verde que, implantadas na Vila Amélia, podem contribuir para a sua transformação em um núcleo que conviva equilibradamente com o rico entorno do Horto Florestal, construindo as bases para a criação de uma ecovila e, consequentemente, de um modelo para uma cidade mais sustentável e resiliente. 


\section{PARTE I. MARCO TEÓRICO}




\section{CAPÍTULO 1}

\section{MARCO TEÓRICO: O PLANEJAMENTO DA PAISAGEM}

Esse capítulo pretende esclarecer alguns dos conceitos mais importantes relativos ao planejamento da paisagem. Começa com uma análise do conceito da arquitetura da paisagem, historicamente um dos primeiros nomes dados à arte de projetar os espaços livres e lidar com os elementos naturais e o território e após isso desenvolve uma sequência de outros conceitos derivados deste ou que o complementam, traçando um panorama do desenvolvimento científico dessa arte. Mostra a importância da relação com a ecologia, o desdobramento dos ideais do desenho ambiental, bem como conteúdo relacionado ao desenvolvimento sustentável e resiliência urbana. Para entender esse pensamento, os conceitos citados acima e sua importância nas discussões contemporâneas sobre cidade, é preciso entender a relação estabelecida entre o homem e o território que habita e a forma como eles vêm interagindo ao longo dos últimos séculos.

Intervir no território faz parte da história do homem desde que este deixou de ser nômade, estabelecendo-se em povoados, por volta do século VIII a.C., quando acontece a Revolução Agrícola. Com a possibilidade de cultivar seu próprio alimento, os antigos nômades iniciam a transformação da terra e a construção de cidades. No vale dos rios Tigre e Eufrates surge a primeira civilização que se tem registro, a Mesopotâmia. A paisagem local se transforma com a construção desse assentamento, canais são criados com fins de irrigação e transporte, contenções às enchentes são montadas juntamente a casarios, ruas e os famosos Zigurates com seus jardins suspensos. A agricultura mais se assemelhava a jardins do que a campos de cultivo e assume importante papel estético na criação das cidades. (JELLICOE, 1987; LAURIE, 1975). 
Paisagem e arquitetura se articulam no decorrer do desenvolvimento da história humana através da associação entre cultura e arquitetura. A paisagem é inspiração e criação humana. A arte de domesticar a natureza em espaços reservados para o prazer e o ócio dá origem ao desenvolvimento do jardim e sua história acompanha a evolução da história da civilização humana. Originado da agricultura, agrega valores estéticos e reflete os valores da sociedade de seu tempo, funcionando como espaço de socialização, encontro, discussões políticas, lazer e práticas esportivas. Com o decorrer do tempo assume funções complexas e variações de escalas evoluindo do jardim de cultivo doméstico aos sistemas ecológicos regionais.

Essa cronologia tem pontos de destaque que marcam a história da arquitetura e planejamento da paisagem e refletem as práticas dos dias atuais. $O$ jardim clássico da antiguidade e sua racionalidade exercem forte influência na criação dos jardins do renascimento italiano, no séc. XVI e na Escola Francesa da paisagem nos sécs. XVI e XVII. Os suntuosos jardins franceses, representados pelos jardins de Versailles, consagram a introdução da perspectiva no projeto das áreas externas a arquitetura e que pretende mostrar o poder do homem sobre a natureza. Sua influência chega à escala urbana e é percebida nas reformas da cidade de Paris desenhadas pelo Barão Haussmann em 1850. (JELLICOE, 1987; NEWTON, 1971).

Já no séc. XVIII e início do XIX, na sociedade inglesa pós industrial, há uma inversão de valores e a natureza perdida devido à rápida expansão das cidades passa a ser valorizada em um movimento de reintrodução da natureza na cidade, que culmina na criação dos parques urbanos ingleses e a "revolução dos jardins paisagísticos" (NEWTON, 1971). Essas áreas mimetizam os elementos naturais e traduzem desenhos que mostram as forças da natureza, o jardim pictórico derivado das pinturas da paisagem e colocam os jardins em patamar de áreas públicas com a criação dos parques públicos urbanos. (JELLICOE, 1987). 
A Escola Inglesa da paisagem inspirou a criação de jardins naturalescos em todo o mundo, mas uma de suas obras em especial, o Birkenhead Park (1834) de Londres, teve grande influência no despertar de uma das figuras mais importantes na história da arquitetura e planejamento da paisagem, Frederick Law Olmsted. Olmsted é um dos mais importantes nomes relacionados ao assunto e seus projetos inovadores estão à frente de seu tempo. Com o projeto do Central Park de Nova lorque (1857), desenvolvido em parceria com o inglês Calvert Vaux, "introduz um novo conceito de paisagismo urbano" (JELLICOE, 1987) criando, em espaço na escala da cidade, ambientes introspectivos e ricos em detalhes. Já no projeto do Emerald Necklace (1886), o Sistema de Parques de Boston, eleva a arquitetura da paisagem a um nível que agrega conceitos de engenharia da paisagem, criando o corredor verde ao longo do Rio Muddy como um complexo sistema de contenção de cheias e áreas de lazer. (JELLICOE, 1987; NEWTON, 1971). Olmsted agrega valores sociais e ecológicos a seus projetos e entende que a natureza pode influenciar positivamente a saúde física e mental das pessoas.

Como decorrência da criação dos parques urbanos e do Parks Movement ${ }^{1}$ surgiram, na transição do séc. XIX para $\circ \mathrm{XX}$, as Cidades Jardim de Ebenezer Howard. Howard pretendia criar espaços que acabassem com a dualidade entre campo e cidade, unindo-os como imã (CHOAY, 2005) que exaltasse "a busca de um ambiente de vida mais belo e saudável" (PANZINI, 2013, p.520) e que fizesse um contraponto perante as condições insalubres da cidade industrial inglesa. As cidades jardim propunham baixa densidade demográfica e muito verde, unindo o melhor da cidade e do campo, com um limite populacional de 35 mil habitantes e cercado por um grande cinturão verde de agricultura. (PANZINI, 2013; HOWARD, 1996).

\footnotetext{
' Parks Movement foi o movimento conservacionista americano que, inspirado pelas obras de George Perkins e Henry Thoureau, deu início a criação dos parques nacionais e estaduais nos estados Unidos da América com intuito de proteger áreas naturais de grande valor.
} 
Após os desdobramentos das duas grandes guerras mundiais e do intenso êxodo rural ocorrido em grande parte do planeta, a sociedade passa a voltar sua atenção para as questões ambientais. Diversos congressos e encontros internacionais chamam a atenção para a questão da finitude dos recursos naturais, da degradação do meio ambiente e para a necessidade de se rumar na direção do desenvolvimento sustentável. Os projetos relacionados à paisagem tomam um rumo holístico, baseados nas premissas da ecologia e pensamento ecossistêmico, que abrange todos os elementos da natureza, incluindo o homem, como parte de um todo que funciona em conjunto. (FRANCO, 1997). Surgem diversas teorias baseadas na ecologia, como a ecologia da paisagem e a ecologia urbana e o enfoque se desloca da composição do espaço exterior para seu funcionamento. A paisagem passa a ser avaliada pelos seus processos, desempenho, características de infraestrutura em uma nova forma de pensar que a coloca como estruturadora de todo o espaço urbano.

\subsection{ARQUITETURA DA PAISAGEM}

Paisagismo tem sido, não cientificamente, o termo mais utilizado no Brasil para traduzir todo tipo de intervenção realizada nos espaços livres e exteriores ao edifício. Profissionais com formação nas áreas da agronomia, biologia, ecologia, meio ambiente e outros o utilizam para designar o trabalho que trata do arranjo de elementos vegetais e manipulação da terra, principalmente para criação de jardins. Por ser muitas vezes relacionado exclusivamente à arte da jardinagem não é adotado entre os representantes da arquitetura que trabalham a paisagem, sendo que estes preferem o termo arquitetura da paisagem, que deriva da tradução da expressão em inglês landscape architecture. 
Acredita-se que esse termo tenha sido usado pela primeira vez no início do séc. XIX, em 1828 em Londres, no título do texto Na arquitetura da paisagem dos grandes pintores da Itália, onde o escocês Gilbert Laing Meason propunha desenvolver uma maior integração entre as residências de campo e os parques ao redor da área metropolitana de Londres. (PANZINI, 2013, p.13).

Em terras americanas, foi usado em 1858 por Frederick Law Olmsted e Calvert Vaux, quando declarados vencedores do concurso para 0 projeto do Central Park. (NEWTON, 1971). Em 1863, em uma carta para a Comissão de Parques de Nova lorque, onde Olmsted e Vaux se auto denominam arquitetos paisagistas, dá-se o primeiro registro histórico oficial que se tem do uso da expressão na América. (MANN, 1993). Por esse motivo, além do incomparável legado de obras que deixou, Olmsted é considerado o pai da arquitetura paisagística.

Newton (1971, p.xxi) define arquitetura da paisagem como "(...) a arte, ou ciência se preferível, de manipular a terra, juntamente com seus espaços e objetos, para o uso seguro, eficiente, saudável e agradável do ser humano." A colocação, apesar de parecer inicialmente simplista, mostra a amplitude e abrangência da temática que trabalha a "terra com seus espaços e objetos" deixando claro sua abrangência multiescalar.

A Associação Americana de Arquitetos Paisagistas (ASLA), mais antiga organização responsável pela representação dos profissionais da área e criadora oficial da profissão, fundada em 1899 na cidade americana de Nova Iorque, utilizou como uma definição inicial da arquitetura da paisagem: "a ciência ou a arte que abrange o planejamento de terras e o projeto dos espaços livres, com a finalidade de criar lugares mais úteis, seguros e agradáveis, bem como a presenvação dos recursos naturais." (ASLA, 1981). Tal definição é bem próxima da que Newton usou em 1971. Alguns anos mais tarde, já com um entendimento mais amplo do tema, a mesma instituição passou a descrevê-la de forma 
mais específica, mostrando a ampla gama de atividades que podem ser abarcadas pela mesma:

"Arquitetura da paisagem é a profissão que aplica princípios artísticos e científicos para a investigação, planejamento, concepção e gestão dos ambientes naturais e construídos. Os praticantes desta profissão aplicam sua habilidade criativa, técnica, conhecimento científico, cultural e político no arranjo planejado de elementos naturais e construídos sobre a terra com uma preocupação com o manejo e conservação dos recursos naturais, construídos e humanos. Os ambientes resultantes devem servir fins úteis, estéticos, seguros e agradáveis. A arquitetura da paisagem pode, para efeitos da preservação da paisagem, desenvolvimento e aperfeiçoamento incluir: investigação, seleção e alocação de terra e recursos hídricos para o seu uso adequado; desenvolver estudos de viabilidade; formular critérios gráficos e escritos para direcionar o planejamento e concepção de programas de construção; elaborar, revisar e análisar planos diretores para $\mathrm{O}$ uso do solo e desenvolvimento; produzir planos gerais para terras, classificar a paisagem e criar planos de drenagem, irrigação, plantação e detalhes construtivos; especificar acabamentos; estimar custos e desenvolver relatórios de desenvolvimento urbano; colaborar na concepção de estradas, pontes e estruturas com respeito aos requisitos funcionais e estéticos da área no qual elas serão colocadas; negociar o arranjo para execução de projetos de áreas de terras; observar o campo e realizar inspeção de construção de área de terra, manutenção e restauração." (ASLA, 1990-91, p. 1, tradução nossa).

Já segundo Panzini:

"É a arte de intervir com elementos naturais, de remodelar os lugares para torná-los aproveitáveis e esteticamente agradáveis; em sentido amplo, compreende as atividades por meio das quais o ambiente, modificado e interpretado pelo homem, torna-se paisagem." (2013, p. 14).

Catharina Lima (2016) entende que a arquitetura da paisagem:

" Trata da construção coletiva da paisagem que se dá através das formas de apropriação, construção e transgressão que as pessoas dão ao espaço e coloca a paisagem como totalidade que se expressa a partir do ponto em que esta (a paisagem) me afeta, eu a percebo, sinto, vivencio (...) nem está fora de mim e nem totalmente 
no meu interior, está no ponto de encontro entre um e outro, em uma relação sujeito - sujeito. "

GIROT (1999) salienta que é vista como amortizadora de danos ecológicos e urbanos causados aos sistemas naturais tendo como a restauração um de seus objetivos principais, já que este mostra a preocupação do homem com a qualidade do seu ambiente imediato. Essa restauração não trata apenas de proteger e recuperar os sistemas naturais, mas também de resguardar a integridade dos registros culturais impressos na paisagem através da construção e evolução da história humana.

Tais explicações explicitam mais detalhadamente o escopo da profissão e a variedade de ações relacionadas à mesma. Além de novamente mostrar a faceta multiescalar da arte de arquitetar a paisagem, que pode se materializar de pequenos projetos residenciais a grandes planos de ordenamento regionais, ganhando expressão nessa última quando permite a perpetuação dos processos ecológicos (SWAFFIELD, 2002), coloca funções que se estendem e entrelaçam com outros campos do conhecimento e outras disciplinas de projeto como as engenharias, a gestão ambiental, a biologia, a geografia, a história, a sociologia, a arte, o patrimônio histórico e a ecologia, compreendendo toda a gestão e planejamento da terra.

Aborda questões estéticas, sociais, econômicas e culturais, pois trata da construção do espaço onde o homem vive e desenvolve suas relações sociais, espaços esses que devem ser projetados de forma a promover e preservar a beleza da paisagem natural e construída, o conforto, a conveniência e a saúde da população. Tais questões reforçam os ideais de Olmsted que entendia que o contato com a natureza é fator importante na manutenção da saúde física, mental e alegria do homem. (LAURIE, 1975). 
Um ponto importante é destacado por Garret Eckbo, em apontamento que destaca a relação do homem com a natureza e a paisagem:

"Uma porção de terra que é desenvolvida ou conformada pelo homem, que vai além dos edifícios, estradas ou utilitários, até a natureza selvagem, projetado principalmente como um espaço para a vida humana (não incluindo a agricultura e a silvicultura). É $O$ estabelecimento das relações entre construção, pavimentação e outros elementos ao ar livre como a terra, a forma das rochas, os corpos d'água, as plantas e espaço aberto, e a forma geral e caráter da paisagem, mas com ênfase principal no conteúdo humano, na relação entre pessoas e paisagem, entre os seres humanos e a tridimensionalidade do espaço ao ar livre, quantitativa e qualitativamente." (1950, p. 1).

Como fica claro na definição proposta por Eckbo, trata da relação entre homem e espaço, das formas como o homem cria e transforma os espaços, imprimindo no mesmo as marcas da cultura de cada tempo. Devido a todos os fatores colocados anteriormente, fica comprovada a importância da disciplina e seu papel fundamental na direção de projetos relacionados ao trato do solo. Com o passar dos anos sua prática se tornou tão diversa que alguns autores já apontam sua fragmentação e criação de diversas outras subdisciplinas (SWAFFIELD, 2002) como o desenho ambiental, desenho urbano ambiental, o planejamento ambiental e toda expansão interdisciplinar que originou disciplinas nos cursos de ecologia ligadas à arquitetura como a ecologia urbana e a ecologia da paisagem.

\subsection{DESENHO AMBIENTAL}

O desenho ambiental surge como uma das vertentes da arquitetura da paisagem que é voltada ao projeto que toma como base de intervenção o funcionamento dos elementos naturais, seus processos, dinâmicas e a interação destes com os processos humanos, "exprimindo 
uma intenção de projeto que transcende as questões estéticas, culturais e funcionais de que trata o paisagismo." (FRANCO, 1997).

Visa a criação de espaços onde o meio biótico e abiótico convivam em harmonia, considerando a conservação das características ambientais locais, originando ordem e equilíbrio ecossistêmico, onde "natureza e sociedade fundem-se numa totalidade organizada" ${ }^{2}$. A colocação fica evidente na explicação de Franco em seu livro Desenho Ambiental: uma Introdução à Arquitetura da Paisagem com o Paradigma Ecológico:

"O Desenho Ambiental distancia-se do Paisagismo quando envolve a ideia não apenas de um projeto, mas a ideia de um processo". Para isso o Desenho Ambiental pressupõe o conceito ecossistêmico em que a ação antrópica esteja incluída, bem como a ideia de nega-entropia inserida na reciclagem dos recursos, na preservação e na conservação ambientais. Isso no plano sócio cultural se traduz na otimização dos recursos energéticos e participação comunitária, tanto no processo de criação das propostas para o ambiente quanto no monitoramento e na gestão destas na fase posterior, ou pré-projeto (uso e avaliação pós ocupação)". (1997, p. 11).

Trata de projetar a cidade em conjunto com a natureza (SPIRN, 1984) entendendo que o suporte físico, ponto de interação entre meio natural e construído, tem uma dinâmica que sofre interferência através das intervenções humanas, que transformam essas características, alterando a intensidade dos processos naturais. Esses processos são vitais para a manutenção do equilíbrio dos ecossistemas e do funcionamento de toda uma rede composta pelos elementos naturais que atua como suporte e provedora de recursos necessários a desenvolvimento da vida na terra.

Em condições naturais, ou sem grandes perturbações, cada elemento do conjunto da natureza funciona como parte do todo exercendo atividades fundamentais ao seu equilíbrio. A essas funções dáse o nome de serviços ecossistêmicos. O solo exerce importante papel na drenagem das águas pluviais, infiltração e recarga das águas subterrâneas, base para desenvolvimento das espécies vegetais,

\footnotetext{
${ }^{2}$ Expressão utilizada por Franco, 1997.
} 
agricultura e suporte para as construções que abrigam o homem. A água é o principal elemento no suporte da vida e tem todo um ciclo, o ciclo hidrológico, que é responsável pela manutenção das águas subterrâneas, dos corpos d'água e dos reservatórios para consumo humano. A vegetação, que depende do solo e da água para se desenvolver, é responsável pela filtragem da água e do ar, umidificação do ar, produção de alimentos, combate à erosão do solo, proteção do solo, amenização das temperaturas e provimento de habitat. Essas funções devem ser preservadas para a garantia do bom funcionamento e equilíbrio do ecossistema. (SCHUTZER, 2013; SPIRN, 1984; CAEM, 2005).

Para isso, os projetos de Desenho Ambiental abordam critérios embasados em princípios de preservação e recuperação dos recursos naturais que consideram as características intrínsecas às regiões estudadas. Dentre essas diretrizes podemos colocar:

- A conservação de áreas verdes e cursos d'água existentes;

- A recuperação de cursos d'água degradados;

- A regulação do ciclo hidrológico (prevenção contra cheias urbanas, permeabilidade do solo, recarga do lençol freático);

- Criação de conectividade ${ }^{3}$ e mobilidade entre áreas verdes através da criação de uma estrutura verde urbana;

- Criação de "buffer zones" (áreas de amortecimento de impactos);

- Criação de condições de habitabilidade e desenvolvimento da vida silvestre;

- Manutenção da biodiversidade;

- Regulação bioclimática;

- Considerações sócio-culturais da população residente e flutuante;

- Regulamentação do crescimento da mancha urbana e da emissão de resíduos poluentes;

\footnotetext{
${ }^{3}$ A conectividade é fundamental para manter o equilíbrio dos ecossistemas e um dos princípios chave dos conceitos de ecologia da paisagem (DRAMSTAD; FORMAN; GODRON, 1996) e infraestrutura verde (BENEDICT; MACMAHON, 2006).
} 
- Organização do tráfego de veículos;

- Priorização do transporte público, de energia limpa e do pedestre;

- Ligação com a educação ambiental e envolvimento da comunidade;

- Abordagem multidisciplinar de questões;

- Sustentabilidade;

- Resiliência urbana e outros. (HANNES, 2008).

O Desenho Ambiental surge na segunda metade do séc. XX, em um momento onde o mundo percebe a escala dos problemas gerados pela degradação ambiental e utilização irracional dos recursos naturais, embalado pela aprovação do NEPA ${ }^{4}$ nos Estados Unidos (1969) e pelas novas teorias de base ambiental desenvolvidas pelos arquitetos paisagistas Ian McHarg e Lawrence Halprin. (FRANCO, 1997). McHarg desenvolve sistema de análise da paisagem que aborda questões geomorfológicas em um sistema de camadas que se tornou referência como método de análise no campo da arquitetura e urbanismo. Halprin, por sua vez, se destaca através dos trabalhos com participação comunitária e é um dos primeiros arquitetos paisagistas a se preocupar com o conceito de qualidade ambiental urbana.

O desenho ambiental mescla conhecimentos técnicos, ecológicos, arquitetônicos, urbanos, biológicos, geográficos, econômicos, sociais, culturais e estéticos que se relacionam na produção de soluções com eficiência de longo prazo. Tem papel estratégico na busca de uma conexão entre ambiente natural e urbano e responde às preocupações da sociedade atual relativas às interferências humanas no meio ambiente e à escassez de recursos, dirigindo ideias e propostas de intervenção que abordem fundamentos de integração para um futuro que caminhe na direção da construção de edifícios, bairros, cidades e territórios sustentáveis.

\footnotetext{
${ }^{4}$ NEPA é a sigla que representa o National Environmental Policy Act, assinado em $1^{\circ}$ de Janeiro de 1970, pelo Congresso Americano que estabelece os pincípios da política ambiental desse país.
} 


\subsection{ECOLOGIA E OS PROCESSOS DA PAISAGEM}

As teorias ambientais, em toda sua variedade de conceituação e aplicação, tem como fundamentação básica a ecologia, que estuda as relações dos seres vivos com seu habitat. Seus princípios datam do século XIX, quando o geógrafo Alexander Humboldt (1769-1859) começou a estudar os vínculos existentes entre os seres vivos e o que ele chamava de "natureza inanimada", os elementos naturais. Humboldt pretendia criar uma nova ciência, a Física do Globo, que integrava diversas disciplinas relacionadas ao estudo do meio natural e às forças que atuam sobre este e mantém a harmonia da natureza. Cria, em 1805, o termo geobotânica para expressar as relações entre as plantas e o ambiente. Ainda no mesmo século, o biólogo alemão Ernest Heinrich Haeckel (1834-1919), seguidor das ideias darwinistas, investiga a relação das espécies com seu habitat e sugere, constatando a dependência dos primeiros em relação ao segundo, o termo "oecologia" para definir essa relação. Colocava a ecologia como a ciência que estuda a fisiologia das relações. (CAPEL, URTEAGA, 1991; NUCCl, 2007).

Pode-se definir ecologia como:

"O estudo científico dos processos que influenciam a distribuição e abundância dos organismos, a interação entre organismos e as interações entre os organismos e as transformações e fluxos de energia e matéria." (LIKENS, 1992, p.8, tradução nossa).

Um dos mais respeitados estudiosos da área foi Eugene Odum (1913-2002). Em seu livro Fundamentos da Ecologia, Odum explica a senilidade da relação homem e natureza, que data dos primórdios da civilização, mostrando que desde a sociedade primitiva era necessário conhecer o ambiente, as plantas, os animais e as forças naturais para que fosse possível habitá-lo. Conta que filósofos gregos como Aristóteles e Hipócrates, apesar de não terem uma palavra específica para nomear essa relação do homem com seu habitat, produziram material 
relacionado à mesma. Como ciência, a Ecologia surge por volta do ano 1900, como disciplina ligada à biologia e hoje é reconhecida como indispensável para o estudo da manutenção da qualidade da vida cotidiana do homem. (ODUM, 2001). Odum, define ecologia como:

"o estudo dos organismos em sua casa, (...) o estudo das relações dos organismos ou grupos de organismos com seu ambiente $e(.$.$) o estudo da estrutura e do$ funcionamento da natureza, considerando que a humanidade é uma parte dela". (ODUM, 2001, p. 4).

Seus conceitos tem abordagem sistêmica com uma nova visão da realidade e da vida, que caminha no sentido da percepção holística. Essa visão deriva da necessidade de entender a complexidade dos processos dos sistemas vivos e dos organismos e deu origem à Teoria Geral de Sistemas, criada por Bertalanffy em 1968, que coloca o Universo como uma estrutura constituida do agrupamento de elementos menores, que conformam uma cadeia complexa, onde essa complexidade é fundamental já que expressa propriedades únicas advindas do relacionamento das partes menores. Propõe uma organização da natureza e de seus elementos com base em hierarquia. (BERTALANFY, 1993 apud $\mathrm{NUCCl}$ 2007). O pensamento sistêmico:

"é pensamento de processo; a forma torna-se associada ao processo, a inter-relação à interação, e os opostos são unificados por meio da oscilação. A construção de uma concepção sistêmica da vida deverá também ser subsidiada pelo conhecimento intuitivo que se baseia em uma experiência direta, não-intelectual, da realidade, tendendo a ser sintetizador, holístico e não-linear." (CAPRA, 1982 apud NUCCl, 2007, p. 79).

Ainda de acordo com Bertalanffy:

"Se definirmos convenientemente o conceito de sistema nós encontraremos os modelos, princípios e leis que podem ser aplicáveis aos sistemas em geral (...), por exemplo, a lei de crescimento exponencial pode ser aplicada para células de bactérias até populações de bactérias, de animais ou de humanos (...) O mesmo tipo de equação, que descreve a competição de animais e plantas na natureza, pode ser aplicado para descrever a competição no campo da economia. Esta 
correspondência é devida ao fato dessas entidades poderem ser consideradas como sistemas, isto é, um complexo de elementos em interação" (BERTALANFFY, 1993 apud NUCCl, 2007, p. 86).

Para entender a ecologia, ciência da natureza, e sua aplicação, não basta explorar seu conceito, é necessário entender sua dinâmica e composição. A ecologia trabalha com a compreensão de que grupos de organismos da mesma espécie são tratados como população, as populações de diferentes espécies que habitam uma mesma área, ou hábitat, são entendidas como comunidade e comunidade e ambiente juntos trabalham como um ecossistema. A dinâmica dessas relações aponta para a fragilidade da vida de organismos individuais, que sozinhos não conseguem sobreviver e para as necessidades das comunidades do ciclo de troca de energia e materiais do ecossistema. Hábitat é o local onde um organismo vive e pode também ser utilizado para definir o local ocupado por uma comunidade completa, incluindo seus componentes bióticos, vivos, e abióticos, não vivos. (ODUM, 2001). A qualidade do habitat varia conforme o tamanho, a largura e a qualidade da vegetação presentes, sendo que quanto mais biodiversas as espécies da flora, maior a chance de variedade das espécies da fauna. Densidade da vegetação e a presença de manchas próximas e cursos d'água são fatores importantes que agregam valor aos habitats, concentrando maior diversidade de espécies animais. (Forman, 1995).

É importante entender como os fluxos de energia e outros elementos como água e nutrientes interagem com os organismos afetando sua existência e interação com o ecossistema. A energia é fundamental para o funcionamento dos processos ecológicos e é adquirida principalmente através da conversão solar pela fotossíntese. Fatores como clima, hidrologia e nutrientes também são significativos para os ecossistemas. $\bigcirc$ clima, temperatura e umidade determinam as espécies que podem sobreviver em determinados ambientes e não em outros, a hidrologia trata da quantidade de água disponível e ela é fundamental à sobrevivência 
de plantas e animais, exercendo também importante papel no transporte de nutrientes e energia. Nutrientes também são essenciais à vida e sua existência é determinada pela capacidade de reciclagem de entrada e saída dos sistemas. (ADLER, TANER, 2015; ODUM, 2001).

No ecossistema, a energia necessária para o seu funcionamento é medida em termos de entradas e saídas e isso determina seu metabolismo. O metabolismo de um ecossistema consiste na quantidade de energia que é utilizada para seu funcionamento e na quantidade de resíduos produzida pelo mesmo. Esse pensamento vale para o meio natural e também para o meio construído. Uma cidade, para seu funcionamento, consome energia, comida e água, elementos necessários para a sobrevivência humana e desenvolvimento de suas atividades e esse metabolismo produz resíduos como lixo e poluição.

As comunidades e seus padrões de biodiversidade são afetados por alterações no sistema ecológico. Perturbações no ambiente obrigam populações, animais ou vegetais, a se comportar de forma diferente, a se deslocar para outro local ou acabam com as indivíduos das mesmas. A inserção de espécies exóticas e disponibilidade de recursos e nutrientes também funciona como fator de perturbaçãos das comunidades. (ADLER, TANER, 2015).

Katl Ritter, em pesquisa de caráter inovador desenvolvida no séc. $X V I I$, estuda as relações entre o meio físico e as atividades humanas, colocando a terra como um teatro onde se desenrola a vida humana. Seus estudos deram origem a uma corrente, derivada da geografia, que ficou conhecida como Ecologia Humana. Tais estudos foram consagradas nas primeiras décadas do séc. XX pelos pesquisadores da Escola de Chicago: Robert E. Park, Ernest W. Burgess que defendiam o estudo da "distribuição espacial dos fenômenos sociais" através das teorias biológicas, da ecologia vegetal e animal. Eles colocam a disputa pelo espaço como uma característica da existência humana que fica mais

\footnotetext{
${ }^{5}$ Termo utilizado por Capel e Urtega em As Novas Ecologias, pg. 32.
} 
evidente na formatação da sociedade urbana industrial, destacando o impacto gerado pela urbanização no espaço e nas dinâmicas sociais. Em estudo de 1925, Burgess compara a cidade a um organismo vivo e os processos de desenvolvimento urbano ao seu metabolismo. (CAPEL, URTEAGA, 1991).

A ecologia humana deriva da geografia e da antropologia, que sempre se preocuparam com os impactos causados pelas ações humanas sobre a paisagem. Tais disciplinas desenvolveram diversos estudos que analisam o poder transformador da cultura humana sobre a natureza e também a força da natureza sobre o estabelecimento das construções humanas. A sociologia também contribui para a disciplina tratando essa relação com enfoque na urbanização e suas consequências sobre a qualidade de vida. (ODUM, 2001).

A disciplina da ecologia deu origem a algumas correntes de pensamento que diferem em entendimento e abordagens sobre a questão ambiental. A mais tradicional delas, e muito seguida por estudiosos ligados à paisagem, é conhecida como Ecologia profunda "b $\mathrm{e}$ teve origem com pensadores e filósofos que consideravam o cosmos em seu todo, animais, plantas e seres humanos como uma unidade integrada e inteligente que estaria sempre apta a buscar sua organização e equilíbrio. (SAHTOURIS, 1991). Dessa visão é que foi derivada a conhecida Hipótese Gaia, de James Lovelock, que tem visão holística e entende o Planeta Terra como um grande organismo vivo onde perturbações pontuais geram desequilíbrios no todo. (CIDADE, 1993; FRANCO, 2000).

As questões referentes à relação entre homem e meio ambiente são de extrema importância para que se possa buscar alternativas de remediação e combate à atual crise ecológica. O modelo de desenvolvimento econômico baseado no consumo, exploração dos bens naturais, necessidade crescente de energia e matéria-prima representa uma ameaça à qualidade de vida do homem na medida em que produz

\footnotetext{
${ }^{6}$ Ecologia profunda é a tradução do termo original em inglês Deep Ecology.
} 
poluentes, lixo tóxico e degrada o meio ambiente de forma irreversível. O ritmo de crescimento da população mundial aponta para um cenário de superlotação das cidades e escassez de alimentos e recursos básicos como água e energia. (CAPEL, URTEAGA, 1991; CIDADE, 1993). Essa situação ressalta a importância de se rediscutir os modelos de desenvolvimento adotados pelo urbanismo e a necessidade de se seguir em uma outra direção, com novos moos de ocupação que respeitem a lógica de funcionamento e a capacidade de suporte do meio físico e dos sistemas naturais.

\subsubsection{ECOLOGIA URBANA}

O estudo da ecologia urbana surge da tentativa de entender os processos relativos às interações entre homem, demais seres vivos e a cidade. Após a identificação, pela Escola de Chicago, da associação entre as relações do homem e seus semelhantes com as relações das comunidades animais, surge o termo ecologia urbana, que trata dos aspectos relacionados às formas de vida de animais, plantas, seres humanos e outros organismos vivos nos diferentes ambientes ou hábitats urbanos, sejam eles naturais, modificados ou construídos. (ADLER, TANER, 2015).

O interesse pelo seu estudo como ciência deriva da percepção de que as cidades são ecossistemas próprios e de que a maior parte dos seres humanos vive hoje em cidades (VITOUSEK et al., 1997), transformando os hábitats naturais e construídos, alterando seus padrões e processos naturais. Vai contra a ideia de que apenas os ambientes naturais devem ser valorizados e que o homem e a cidade são vilões que somente deterioram a natureza, entendendo que diversidade cultural e biológica, trabalhadas conjuntamente, caminham em direção à resiliência e sustentabilidade, (BERKES et al., 2003) já que as cidades, com toda sua diversidade e densidade populacional (vegetal, animal e humana) podem 
ser o local de construção de soluções resilientes e duradouras. (NIEMELÃ et al., 2011).

Trabalha com a ecologia na cidade e com a ecologia da cidade sendo que a primeira trata dos processos ecológicos que acontecem dentro das cidades e a segunda, de como esses processos se transformam no ambiente urbano devido a sua relação com seus elementos e com o homem, (WU, 2008). Wu ainda destaca que um dos principais focos da ecologia urbana é entender as relações temporais e espaciais entre os processos urbanos e os processos ecológicos.

Por assim ser, a ecologia urbana se coloca na interdisciplinaridade entre a ecologia, ecologia humana, o planejamento urbano, a arquitetura, a geografia, a economia, as ciências políticas, a engenharia, a sociologia, os senviços sociais, a antropologia, a psicologia e as ciências da saúde (ALBERTI, 2008; MCDONNEL, PICKET, 1993), sendo que a primeira pesquisa integrada na área data de 1970 com o programa da UNESCO "O homem e a biosfera", MAB, que trabalha conjuntamente com as ciências naturais, as ciências humanas, a engenharia e o planejamento. Com base nessas definições, podemos entender que integra a pesquisa das ciências naturais e sociais, de seus fundamentos e conhecimento aplicado, para explorar e esclarecer as múltiplas dimensões dos ecossistemas urbanos. (MCDONNELL, 2001). Alberti sugere que "(...) ecologia urbana é o estudo das formas em que os sistemas humanos e ecológicos evoluem conjuntamente em áreas urbanizadas." (ALBERTI, 2008, p. XIV).

Um dos novos conceitos que a ecologia urbana apresenta é a quebra do "paradigma do equilíbrio". Durante o último século, os estudos ambientais se basearam na ideia de que o planeta terra vive em um equilíbrio que pode ser alterado por ações humanas, como a poluição e emissão de gases que contribuem com o efeito estufa, e naturais como terremotos e tsunamis. Esse equilíbrio veio se mantendo devido à capacidade de resiliência do planeta de se adaptar às mudanças, mas estaria em risco devido aos efeitos produzidos pela urbanização excessiva 
e destruição dos recursos naturais ocorridas nos dois últimos séculos. (PICKETT et al., 1992). O novo entendimento parte da concepção de que não existe um equilíbrio mantido pela capacidade de resiliência do Planeta Terra e sim um processo em constante evolução que reage com toda a sorte de impactos, alterações, entrada e saída de materiais, energia e que, portanto, a ecologia do planeta é um sistema aberto, regulado por forças externas que estão em constante processo de transformação e desenvolvimento. A partir desse entendimento fica clara a importância de se adicionar o elemento humano como fator que integra, interage e altera os ecossistemas. (PICKETT et al., 1992; MCDONNEL, PICKET, 1993; MCDONNELL, 2001).

Assim como o corpo humano, a cidade e os ecossistemas urbanos possuem um metabolismo, um ciclo de funcionamento que pode ser chamado de metabolismo urbano. Esse metabolismo urbano tem vias de entrada, saída e um sistema de processamento de materiais e energia. Para viver, os seres humanos necessitam de água, alimento e da energia necessária para o desenvolvimento de suas atividades diárias como deslocamentos, construção de moradias, que demanda tipos específicos de materiais, aquecimento, refrigeração, energia elétrica e outros. Como resposta a essas atividades são produzidos resíduos de diversas formas como lixo, calor e gases. (ADLER, TANER, 2015)

A sociedade pós industrial tem valores de entrada e de saída muito mais altos que nos tempos antigos. Conforme os costumes se alteram e novas necessidades do mundo contemporâneo são estabelecidas, mais entrada de energia e insumos são necessárias para criar o suporte necessário à vida no mundo contemporâneo. A comunicação via internet, a crescente demanda por meios eficazes de transporte, o consumismo típico da sociedade capitalista e a demanda cada vez maior por conforto impactam fortemente os números de entrada e saída dos processos que regulam o funcionamento da vida urbana. Alimentos industrializados necessitam de mais energia e matéria prima para serem produzidos e 
produzem maior quantidade de lixo e resíduos. Jardins privativos demandam uma enorme quantidade de água para irrigação e produtos manufaturados são transportados de longas distâncias, consumindo mais combustível e gerando mais poluição e gases nocivos, que contribuem para o efeito estufa. (ADLER, TANER, 2015)

Esses fatores colocam a importância do entendimento dos elementos que formam o ambiente urbano e de sua integração através dos processos existentes nos sistemas citadinos. Esse sistema de elementos é composto pela vegetação, sendo ela formada pela vegetação urbana, pelos fragmentos naturais e manchas florestais, pelos jardins projetados, telhados e paredes verdes, pelos ambientes marinhos e corpos de água doce, pelos impactos na saúde pública e nos aspectos estéticos, comunitários e recreativos dos ambientes urbanizados. (FLORGARD, 2004; GASTON et al. 2005; FELSON, PICKETT, 2005; OBERNDORFER et al. 2007; CHAPMAN, UNDERWOOD, 2009; PAUL, MYERS, 2001; FRUMKIN et al. 2004 apud MCDONNELL, 2001). Esse ecossistema urbano tem como grande motor o ser humano, que o altera, e o tempo e local dos ciclos da natureza, apresentando "novos desafios à antiga batalha da sobrevivência e da reprodução". (ADLER, TANER, 2015).

Para produzir os bens necessários à sua sobrevivência o homem altera os ciclos e os elementos que compõe o espaço urbano. O solo é recortado, aterrado e impermeabilizado para a construção das cidades e seus nutrientes esgotados através das práticas agrícolas que produzem o alimento. As atividades industriais, agrícolas e meios de transporte poluem o solo, a água e o ar com seus excrementos. Cursos de rios são alterados e canalizados para a construção de vias e edifícios, barramentos são construídos para obtenção de energia. Matas são derrubadas para implantação de campos agrícolas, pastagens e construção de edifícios. (SPIRN, 1984; SCHUTZER, 2012; HERZOG, 2013). Essas alterações nos elementos que formam o ecossistema urbano geram impactos em seu funcionamento, em seus processos e alteram toda a estrutura de 
relacionamento entre os seres orgânicos e inorgânicos, os animais, as espécies vegetais e o homem. Como consequência dessas alterações surgem efeitos como a emissão de gases do efeito estufa que contribuem para o aquecimento global, o assoreamento dos leitos dos rios que prejudica o desenvolvimento da vida silvestre, perda da biodiversidade e extinção de espécies, entre outros. É por isso que planejadores urbanos, arquitetos, organizações governamentais e tomadores de decisão precisam entender como funcionam os processos ecológicos e sociais, para que estejam habilitados a desenvolver projetos e intervenções que possam resolver os conflitos ecológicos presentes nas cidades e restabelecer a ordem de seus processos naturais.

\subsubsection{ECOLOGIA DA PAISAGEM}

A ecologia da paisagem surge, no século $X X$, como uma tentativa de incluir o homem e a sociedade nos estudos ecológicos sobre o meio físico. Ela tem origem na Europa, em especial Alemanha e Holanda. Como termo científico foi utilizado inicialmente por Troll, em 1939, que através da utilização de fotos aéreas desenvolveu estudo sobre o uso do solo e das paisagens, em uma tentativa de aproximar estudos geográficos e da biologia. O termo paisagem, em seus estudos históricos, deriva do entendimento da geografia que engloba a totalidade do espaço, cultura, sociedade e ações humanas. (NUCCl, 2007). Segundo os autores Naveh e Lieberman (1984), a Ecologia da Paisagem coloca o homem como esfera totalmente integrada ao seu meio físico, geográfico, espiritual e mental.

A escola americana se desenvolveu em um rumo diferente, excluindo o homem de seus estudos e focando nas interações entre os próprios elementos da natureza e processos naturais na composição da paisagem. O estudo de maior impacto no campo é o de Richard Forman e Michel Godron (1986) intitulado Ecologia da Paisagem. O conceito surge da ausência de estudos específicos sobre o arranjo, processos e 
dinâmicas ecológicas entre os diferentes elementos e manchas de paisagem. Segundo Richard Forman, pode ser entendido:

"simplesmente como a ecologia das diversas paisagens como as florestas, os subúrbios, os desertos e as áreas agrícolas. Isso significa o estudo das interações entre organismos e seu ambiente (ecologia) em áreas onde os ecossistemas locais e usos da terra são repetidos em formas similares (paisagens)." (FORMAN, 2016, p.1, tradução nossa).

Para Pickett e Cadenasso (1995) a Ecologia da Paisagem trata dos efeitos causados pelos padrões espaciais nos processos ecológicos. Wu e Hobbs colocam a ecologia da paisagem como: "a ciência que estuda e aprimora as relações dos padrões espaciais e dos processos ecológicos (e socioeconômicos) nas múltiplas escalas." (2013, p.39, tradução nossa). Aspectos econômicos e culturais se fazem presentes também no conceito já que representam a integridade de fatores que movem a sociedade e suas dimensões estéticas, comunitárias, seus padrões recreativos, de transporte e de manutenção de descarte de resíduos. (DRAMSTAD, OLSON, FORMAN, 1996).

Parte do entendimento de que o meio físico funciona como um grande mosaico que integra fragmentos de paisagem. Esses fragmentos podem ser pequenas áreas vegetadas, cursos d'água, florestas e outras áreas onde a natureza se faça presente, sendo estas naturais ou criadas pelo homem (FORMAN, 1995). O mosaico ganha força e permite o pleno funcionamento dos processos ecológicos quando funciona de forma integrada, formando um grande sistema que perpetua os fluxos de matéria e energia necessários ao equilíbrio do ecossistema. Esse sistema, ou mosaico, é formado por três elementos principais: a matriz ecológica, as manchas e os corredores ecológicos, onde cada elemento tem função específica. Os diferentes arranjos e formas de comportamento entre esses elementos é que dão origem aos distintos modelos de paisagens presentes no espaço e esses arranjos podem ser alterados tanto pela 
atividade humana quanto pelos processos naturais. (DRAMSTAD, OLSON, FORMAN, 1996).

A importância da leitura dos elementos como sistema integrado e não como simples conjunto decorre do fato de que a fragmentação de hábitats é a maior ameaça à vida silvestre e que esta depende da qualidade desses hábitats, que dependem consecutivamente de seu tamanho, forma e conectividade. Esses fatores afetam a qualidade dos processos ecológicos desses ecossistemas, interferindo em sua estabilidade e funcionamento, bem como de seus elementos componentes como vegetação, terra, água e a própria vida silvestre. (Forman; Godron, 1986; Kihslinger; Wilkinson; McElfish, 2013). Quanto mais fragmentado um mosaico for, maior é a importância da qualidade de suas conexões. A conectividade pode ser estrutural, referindo-se apenas à estrutura da paisagem, sem considerar sua população, e funcional, quando considera as respostas de seus organismos ou população. (ROCHA et al., 2006).

Muita diversidade é apresentada na conceituação do termo matriz, que aparece, na maioria dos casos, como o modelo formado pela conexão entre corredores e manchas. Esse trabalho vai tratar como matriz ecológica, o maior e mais importante elemento do mosaico, que funciona como núcleo e exerce papel dominante no funcionamento do sistema ecológico (FORMAN, GODRON, 1986). A matriz é o berço de espécies animais e vegetais e representa um ecossistema em equilíbrio, onde suas principais características são a heterogeneidade e a biodiversidade de vida animal e vegetal. Trataremos o conjunto formado pelas diversas manchas e suas conexões pelo nome de mosaico, como inicialmente sugerido por Forman e Godron (1986).

Corredores ecológicos, ou de biodiversidade, são os elementos de formação linear com a função de conectar os núcleos e fragmentos de vegetação e que funcionam como áreas de deslocamento de espécies, permitindo assim o fluxo gênico entre as espécies vegetais e animais. 
(Forman, 1986; Hobbs, 1992; JONGMAN \& KAMPHORST, 2002). São de grande importância para a manutenção do equilíbrio ecológico e conexão entre paisagens fragmentadas. São frequentemente compostos por áreas marginais de cursos d'água, cumeeiras e trilhas animais, de origem natural, corredores verdes ao longo de rotas de veículos e ferrovias, áreas sob linhas de alta tensão, valas e trilhas de caminhadas, criadas pelo homem.

Como alguns dos serviços ecológicos providos por eles podemos citar a proteção à biodiversidade; a manutenção do ciclo das águas atuando como áreas de controle de cheias, sedimentação, qualidade da água e vida animal; proteção agroflorestal onde podem atuar como barreiras de vento e erosão do solo. Também podem atuar como área de recreação como trilhas de caminhada e ciclovias; provedores de sentido de identidade à comunidade através de sua composição como cinturões verdes nas cidades, que também tem papel importante na biodiversidade e qualidade e vida, possibilitando diferentes rotas às espécies entre áreas fragmentadas. (Forman, 1995).

Dados relativos ao design, forma espacial e as características de seus elementos são fundamentais para determinar sua funcionalidade como conector ecológico, que pode ser indicada pela sua competência como área de passagem, transição com hábitats adjacentes, limite de amortecimento e proteção da área núcleo. Exercem papel de condutores quando responsáveis pelo deslocamento de elementos e como barreiras quando impedem seu cruzamento. (Forman, 1995; Dramstad; Olson; Forman, 1996).

Para os corredores ecológicos, sua largura é muito importante, pois pode determinar sua funcionalidade, ou não, como passagem de espécies animais, como mostra a figura 01 que apresenta as larguras necessárias de passagem para diversos tipos de espécies. Interrupções no corredor podem afetar o movimento de espécies no seu interior. O padrão conhecido como trampolim, traduzido do termo em inglês stepping stone, 
pode ser positivo quando o corredor não pode se configurar por completo ou quando apresenta quebra de continuidade. A distância entre esses trechos de trampolim influem visualmente no movimento das espécies e também são utilizadas conforme seus padrões de deslocamento. Quantidade de trampolins e distanciamento entre eles podem interferir na conectividade entre manchas. (Dramstad; Olson; Forman, 1996).

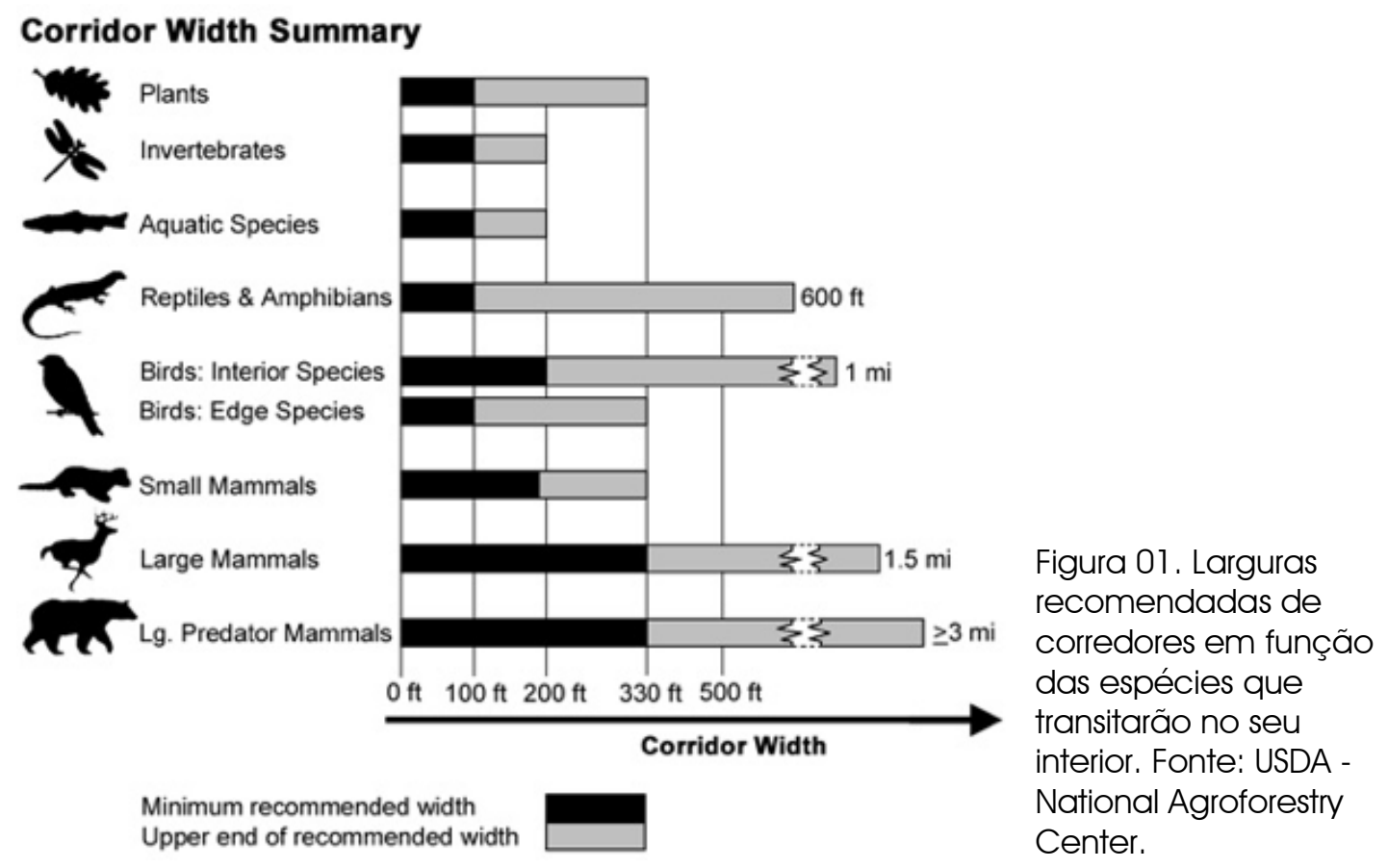

Cursos d'água são exímios corredores ecológicos e tem importante função como filtro de poluentes derivados do escoamento superficial sendo que suas margens devem ser largas o suficiente para abrigar as áreas de várzea, elemento tão importante no controle do ciclo hidrológico e manutenção de diversas espécies da fauna e flora. (Dramstad; Olson; Forman, 1996; Hannes; Suassuna, 2016). Esses corredores de vegetação ripária natural formam os mais dinâmicos, diversos e complexos hábitats terrestres, contemplando diversos processos naturais e funcionando como elemento paisagístico e ecológico fundamental para os ecossistemas. (Naiman; Décamps; Pollock, 1993). Ver figura 02. 


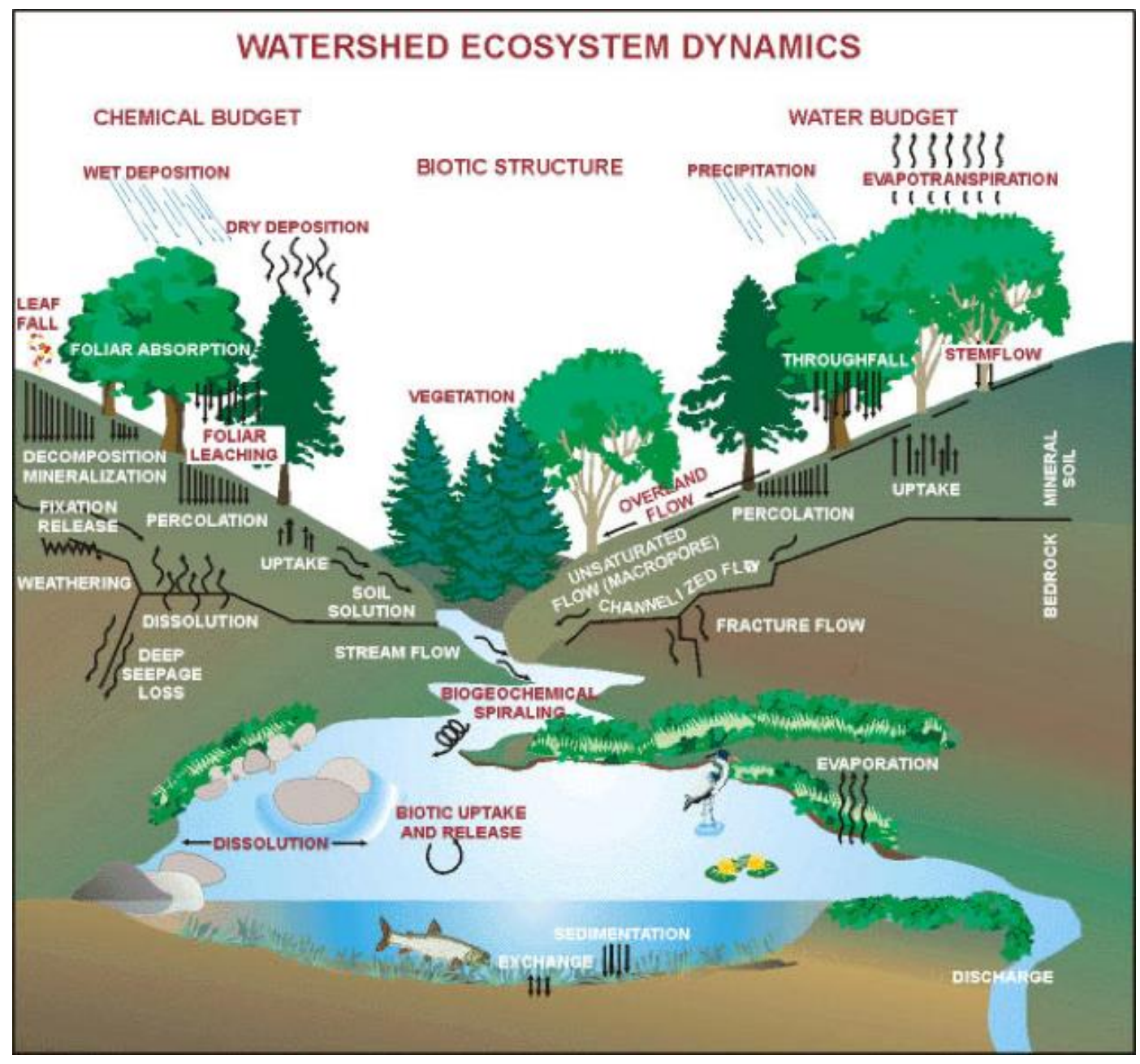

Figura 02. Dinâmica de fluxos ecológicos dos corpos d'água. Fonte: United States Environmental Protection Agency.

Forman (1995) descreve as cinco funções básicas dos corredores ecológicos, como mostra a figura 03. São elas: a promoção de hábitat, condução de movimento e fluxo entre manchas, promoção de fluxo gênico com a matriz ecológica, filtrar perturbações e contribuir como depósito temporário de material orgânico e outros elementos.

É importante destacar as diferenças conceituais entre corredores ecológicos e corredores verdes, termos muitas vezes usados no mesmo sentido. Esse trabalho adota para corredores verdes as definições de Franco e Ahern, já que é consenso no Brasil que os corredores verdes não têm foco principal em suas funções ecológicas. Ahern (1996) coloca que são redes de espaços planejados com funções recreativas ecológicas, 
culturais, estéticas e outras, mostrando sua função ecológica, mas não dando destaque à mesma. Franco salienta suas funções como corredores de mobilidade segura que podem resgatar a memória de trilhas que incorporam valores paisagísticos.

\section{FIVE CORRIDOR FUNCTIONS}

\section{(al Habitat}

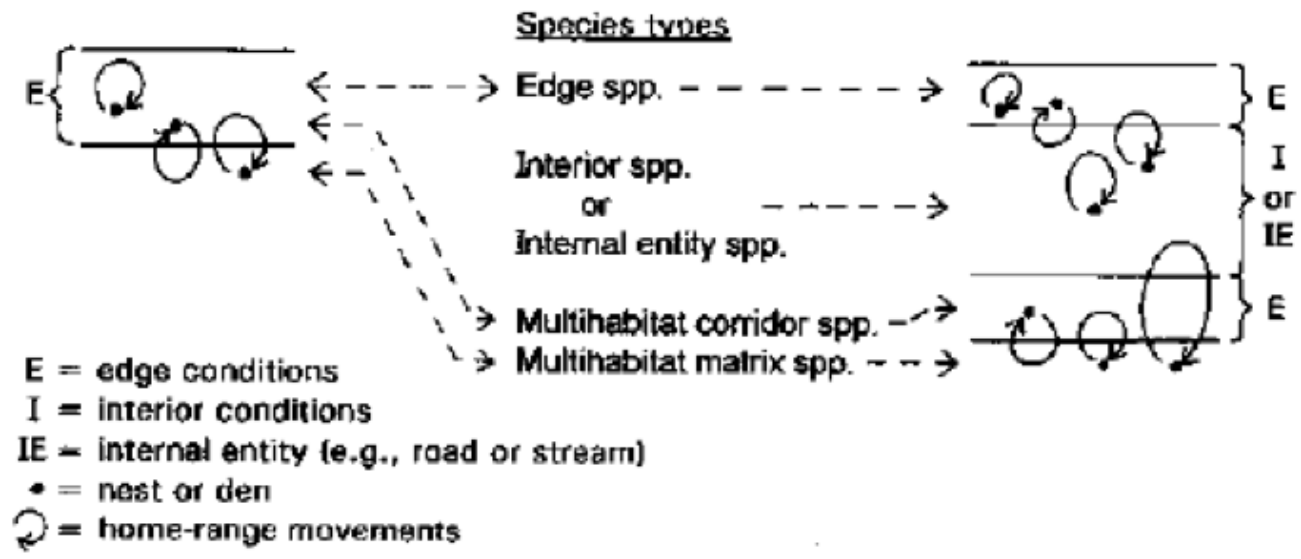

(b) Conduit

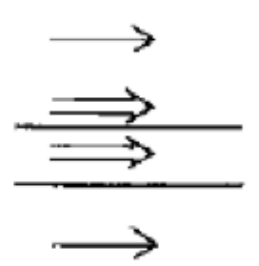

(c) Filter

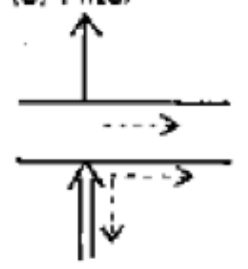

(d) Source

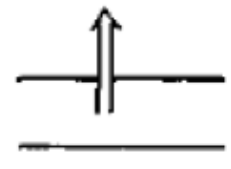

(e) Sink

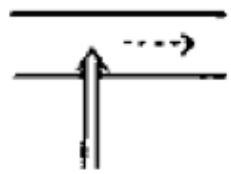

Figura 03. Cinco funções dos corredores de biodiversidade. Fonte: Forman, 1995.

Manchas são amostras, fragmentos de paisagem, com certa composição estrutural, habitadas por comunidades específicas. (FORMAN; GODRON 1981). São às vezes chamadas de ilhas de biodiversidade, devido a conformarem áreas que apresentam certo grau de isolamento e fragmentação. Podem ser originadas devido a quatro causas: à fragmentação de áreas maiores como as interferências humanas e urbanas em áreas de mata e introdução de estradas, à introdução de áreas verdes pelo homem como a criação de praças e parques, pela perturbação de áreas maiores que descola fragmentos ou ilhas destas 
devido às queimadas ou tempestades de vento e por questões ambientais específicas como a formação de oásis nos desertos. (Dramstad; Olson; Forman, 1996).

Dependendo de sua origem, apresentam diferenças em sua estrutura e estabilidade e podem causar impactos positivos ou negativos no mosaico ecológico. Por exemplo, a introdução de vegetação exótica próxima á área sensível de wetland pode ser prejudicial à mesma já que vai alterar seus processos ecológicos naturais, já a manutenção de área vegetada remanescente de floresta em área de práticas agrícolas é positiva, pois representa a conservação da biodiversidade natural de parte da floresta suprimida. (Dramstad; Olson; Forman, 1996; Forman \& Godron, 1981).

Assim como nos corredores, a estrutura, a forma, o tamanho e as dinâmicas entre as manchas, geram diferentes influências no seu funcionamento. Dividir uma mancha em duas gera maior área de borda e perda de hábitat interno, diminuindo as espécies do hábitat interior e aumentando as da borda, o que altera o funcionamento desse ecossistema como um todo. Manchas maiores tem maior probabilidade de abrigar mais espécies e manchas muito pequenas podem levar à extinção de espécies, probabilidade que também é acentuada em manchas com hábitats de baixa qualidade. Manchas maiores também propiciam maior biodiversidade, protegem aquíferos, cursos d'água e fornecem abrigo a animais de maior porte. A divisão de manchas nem sempre é benéfica, mas pode trazer benefícios quando cria barreiras a fatores de distúrbio. (Dramstad; Olson; Forman, 1996; Forman \& Godron, 1981).

Em relação ao número de manchas em um mosaico sabe-se que a perda de manchas do mosaico gera perda de hábitat e biodiversidade do ecossistema, bem como a redução da meta população, que é população que consegue viver em manchas separadas. Duas manchas de tamanho grande são necessárias para manter a riqueza de espécies e 
um número ideal seria entre 4 e 5. Algumas espécies conseguem sobreviver em hábitat separados em manchas próximas. A probabilidade de extinção de espécies é maior em uma mancha isolada do que em uma mancha inserida em um mosaico, bem como uma mancha próxima a uma área de maior biodiversidade ou à matriz ecológica tem maior chance de ser recolonizada por diferentes espécies. É por isso que a seleção de áreas de conservação em um projeto tem que levar em conta fatores como sua contribuição para o sistema como um todo, seu tamanho e localização. Considera-se ideal, manchas arredondadas que protegem seu centro, com bordas não lineares e que derramem pontas que façam o papel de dispersores de materiais e espécies, como mostra a figura 04. (Dramstad; Olson; Forman, 1996; Forman \& Godron, 1981).

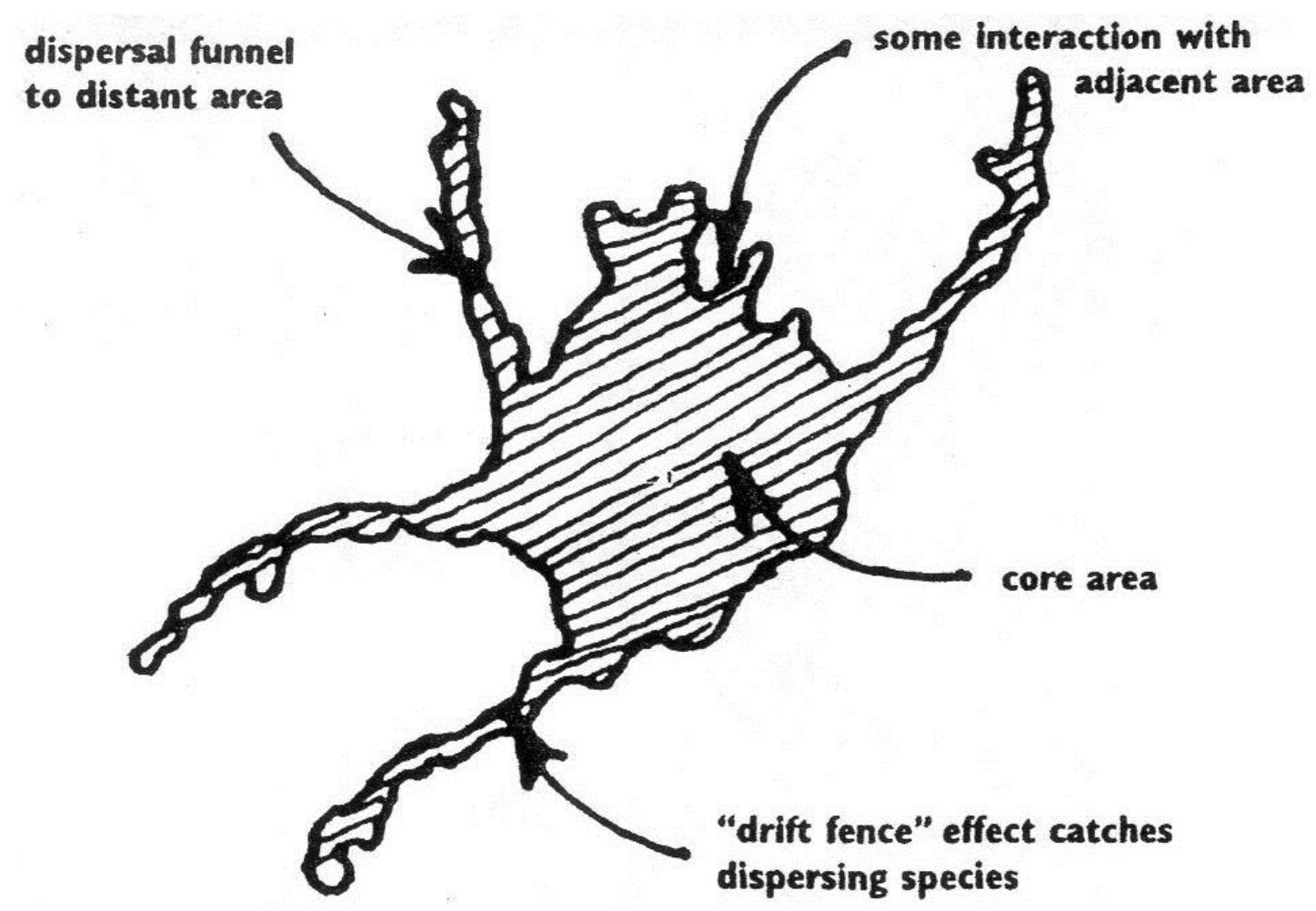

Figura 04. Forma ideal de uma mancha. Fonte: Dramstad; Olson; Forman, 1996.

Outro ponto muito importante a ser considerado nos elementos do mosaico ecológico são suas áreas de borda e fronteiras. As áreas de borda possuem características diferentes do que as porções centrais 
desses elementos e sofrem maior influência e perturbações já que estão em maior contato com o meio externo. As bordas podem ter tamanho diferenciado ao longo das manchas e sua largura regula quanta perturbação chegará ao interior do sistema, já que funcionam como barreiras e filtros. Formato e diversidade de componente da borda também são fatores importantes. Fronteiras curvilíneas propiciam maior movimento de espécies e incremento de biodiversidade, pois interagem mais com o exterior. (Dramstad; Olson; Forman, 1996; Forman \& Godron, 1981).

Wu e Hobbs (2007) apontam dez pontos principais a serem considerados nos estudos e projetos de ecologia da paisagem: (1) fluxos de energia nos mosaicos de paisagem; (2) as causas, processos e consequências do uso da terra e mudanças na cobertura vegetal; (3) as dinâmicas não lineares e as complexidades dos sistemas de paisagens; (4) diferentes escalas e suas especificidades; (5) desenvolvimento metodológico; (6) relação das métricas da paisagem com os processos ecológicos; (7) integração dos seres humanos e suas atividades na ecologia da paisagem; (8) otimização dos padrões naturais; (9) conservação da paisagem e sustentabilidade e (10) busca de dados concretos para desenvolvimento de análise. (WU, HOBBS, 2002; 2002).

Cada um desses pontos se desenvolve para o entendimento da complexidade das abordagens da disciplina. Quando é colocada a questão dos fluxos de energia é importante entender como energia, matéria e organismos se movimentam, relacionam e afetam o padrão de composição que forma o mosaico da paisagem. Além disso, deve-se ter conhecimento de que esse sistema de trocas e as dinâmicas dos ecossistemas funcionam de formas diferentes e tem diferentes efeitos de acordo com a escala em que estão inseridos. (WU, HOBBS, 2007).

Dramstad, Forman e Olson ressaltam três características importantes para o andamento das atividades e desempenho dos sistemas vivos dos

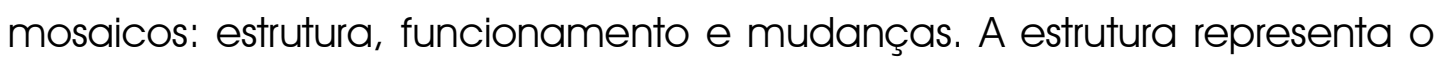


padrão espacial ou o arranjo dos elementos do mosaico. $\bigcirc$ funcionamento aborda os movimentos de energia, materiais, organismos, ventos, plantas e animais no sistema. As mudanças representam as alterações dos padrões espaciais e de funcionamento no tempo. (DRAMSTAD, OLSON, FORMAN, 1996).

Os últimos pontos expostos expressam a importância do entendimento do conceito e dinâmicas da ecologia da paisagem para o planejamento urbano e da paisagem. Só entendendo a implicação de suas ações e as consequências de suas intervenções na paisagem, arquitetos e urbanistas serão capazes de projetar de forma menos impactante e fragmentadora no espaço urbano.

\subsubsection{ECOSSISTEMAS}

Arthur Tansley, ecólogo britânico, propõe em 1935 o termo ecossistema para definir a organização das comunidades bióticas e o sistema formado pelo conjunto dos "organismos e dos fatores inorgânicos". O ecossistema passa a ser entendido como o elemento que exprime "as unidades fundamentais da natureza na terra". Esse entendimento altera o estabelecido por Darwin anteriromente, que colocava a espécie como unidade mínima de sobrevivência, em uma concepção mais holística e sistêmica. (NUCCl, 2007, p. 83-84). Esse é o princípio da teoria dos sistemas da ecologia, que coloca a unidade mínima de sobrevivência como a relação indivíduo - habitat, elementos interdependentes que funcionam em conjunto e garantem sua sobrevivência e funcionamento do todo. Dessa definição surge a noção de ecossistema, que pode ser definido como:

"Qualquer unidade que inclua a totalidade dos organismos de uma área determinada interagindo com o ambiente físico e forme uma corrente de energia que conduza (...) a uma diversidade biótica e ciclos de materiais claramente definidos dentro do sistema ecológico ou ecossistema" (ODUM, 1988, p.11). 
Ainda segundo Odum (1988), o ecossistema é formado por 6 componentes: susbtâncias inorgânicas envolvidas nas trocas de materiais; compostos orgânicos que conectam meio biótico e abiótico; regime climático, que compreende a temperatura e outros elementos físicos; produtores, organismos capazes de produzir alimento através de substancias inorgânicas; macroconsumidores, organismos que ingerem outros organismos ou matéria orgânica e microconsumidores, organismos que fazem a decomposição de outros organismos. Em relação à funcionalidade, são 6 as funções desempenhadas pelos elementos dos ecossistemas: "(...) circuitos de energia; cadeias alimentares; diversidade de padrões no tempo e no espaço; ciclos nutritivos; desenvolvimento e evolução; e controle." (p. 11, 12). Os componentes citados apresentam diferentes funções, dentre as 6 relacionadas e essa dinâmica entre estrutura e funcionamento é que determina a característica de cada ecossistema, ressaltando que a interpedependência dos elementos e o fato de que "as partes são operacionalmente inseparáveis do todo" são a chave desse conceito. (p.13).

Pickett e McDonnell (1993) sugerem que os humanos são parte integrante dos ecossistemas e também um de seus agentes, assim como outras forças externas como alagamentos e queimadas, que podem alterar e regular sua estrutura e função. O Conselho de Avaliação Ecossitêmica do Milênio confirma tal colocação quando define ecossistema como:

"um complexo dinâmico de comunidades de plantas, animais, microorganismos e o meio ambiente inorgânico, que interagem como uma unidade funcional. Os seres humanos são parte integrante dos ecossistemas, que fornecem grande variedade de benefícios às pessoas (...). Os ecossistemas variam enormemente em tamanho; tanto uma poça d'água temporária na cavidade de uma árvore como uma bacia oceânica são exemplos de ecossistemas." (AM, 2005, p. 29). 
Os ecossistemas abrangem uma variada gama de hábitats, sendo estes naturais ou alterados pelo homem, onde as cidades apresentam hábitats profundamente alterados e muito próximos uns aos outros. Esses hábitats apresentam profunda diferenciação em seus ecossistemas e dinâmicas específicas que determinam, por exemplo, quais espécies conseguem sobreviver, qual o nível de perturbação que suportam e quais serviços fornecem à sociedade. (ADLER \& TANNER, 2015).

A biodiversidade é um conceito muito importante para a ideia de ecossistemas e os dois estão relacionados, sendo a diversidade parte da estrutura dos ecossistemas. A Convenção sobre Diversiadde Biológica, $\mathrm{CBD}$, decreto do Ministério do Meio Ambiente, define biodiversidade como:

"(...) a variabilidade entre organismos vivos de todas as origens, englobando, entre outros, os ecossistemas terrestres, os marinhos e outros ecossistemas aquáticos e os complexos ecológicos de que fazem parte. Isso inclui a diversidade intra-espécies, interespécies e dos ecossistemas". (BRASIL, MMA, 1994, artigo 2).

Os processos ecológicos e os ciclos do ecossistema dependem de energia para funcionar. A maior fonte produtora de energia no meio natural é "a conversão de luz solar em energia química através da fotossíntese". (ADLER \& TANNER, 2015, p.35). Água, nutrientes e alimento também são fontes de energia sendo que as plantas obtém água e nutrientes principalmente do solo e os animais os conseguem no próprio ambiente e nos alimentos. (AM, 2005). Os fluxos de energia, água, nutrientes e outros materiais no ecossistema determinam seu grau de estabilidade, seu funcionamento e até sua estrutura física. Entender esses fluxos é primordial para tratar asuntos relacionados ao ecossistema. $O$ clima, que determina temperatura e índices pluviométricos, estabelece os limites de sobrevivência dos organismos e onde estes conseguirão sobreviver. A água, além de ser fundamental à vida de espécies animais e vegetais, também está relacionada ao transporte de nutrientes e, portanto, é de grande importância aos processos ecológicos. Nutrientes como o 
carbono e o nitrogênio são essenciais à vida e, portanto sua disponibilidade também tem papel regulador no ecossistema. (ADLER \& TANNER, 2015). Com base nesses princípios, o que diferencia os ecossistemas naturais dos urbanos é a grande quantidade de energia de entrada e saída dos ambientes urbanos, necessárias aos processos relativos à vida nas cidades, bem como a modificação de hábitats e produção de resíduos poluentes. O homem modifica o ambiente natural para a construção das cidades, represa rios, altera as condições do solo, constrói edifícios e derruba vegetação. Para exercer suas atividades diárias, para se locomover, produzir materiais e manter um nível de conforto térmico satisfatório ele utiliza energia, na maior parte das vezes advindas da queima de combustíveis fósseis. Essa queima e essas atividades produzem resíduos, muitos deles poluentes, que contaminam o ar, água e o solo. Toda essa dinâmica faz parte do ecossistema urbano que tem ciclos e processos diferenciados dos naturais. (ADLER \& TANNER, 2015; AM, 2005; SPIRN, 1984; SCHUTZER, 2012).

Essas alterações nos ecossistemas afetam seu funcioanmento e sua produção de serviços ao homem e esses fatores de mudança são denominados na ecologia de impulsores, sendo definidos como "qualquer fator natural ou induzido pelo homem que, direta ou indiretamente, causa uma mudança em um ecossistema". (AM, 2005, p. 49). Os impulsores podem ser diretos, quando impactam diretamente nos processos ecossistêmicos ou indiretos, quando produzem causas que terão ação indireta nos mesmos. Podem ser classificados, de acordo com suas características de impacto em: demográficos, quando relativos às variações nas taxas populacionais e seus impactos no ambiente; econômicos, que regulam crescimento econômico, padrões de estilo de vida e consumo; sociopolíticos, como o papel do público nas tomadas de decisão e a descentralização nas tomadas de decisão; científicos e tecnológicos, como o aumento de pesquisas e conhecimento, a crença de que a tecnologia pode suprir os serviços ecossistêmicos e a mudança 
no estilo de vida provocada por esse desenvolvimento tecnológico; culturais e religiosos, como condicionadores das percepções, valores e ações da sociedade sobre a natureza e, por último, impulsores físicos, qúimicos e biológicos, como a radiação solar e os eventos climáticos.

Em termos de valoração, podemos dizer que os ecossistemas têm valor intrínseco aos seres humanos e este deriva de sua valoração cultural, ética, estética, religiosa, filosófica e ecológica e estes podem ser exemplificados através de casos como a utilização de uma espécie vegetal como símbolo de uma cidade, a associação de espécies a locais sagrados e a definição de regras sociais relacionadas ao seu uso. Seu valor também pode ser medido de acordo com os serviços que presta à sociedade, como abastecimento de água, filtragem do ar e outros. Esse valor e suas propensões econômicas têm sido altamente reconhecidos nos últimos anos, o que fica evidente através do mercado de venda de créditos de carbono. (AM, 2005).

A abordagem ecossistêmica é estratégica para a manutenção integrada da terra, recursos naturais e assentamentos humanos e o entendimento de como os ecossistemas se comportam, suas dinâmicas e seus limites, especialmente nos ambientes urbanos, são fundamentais para se entender as ações necessárias, em termos de conservação e intervenção, que devem ser aplicadas sobre os mesmos. (ELMQVIST, 2011; AM, 2005). A avaliação também é ferramenta importante e pode colaborar na compreensão de diversos pontos como:

- A relação dos vínculos entre ecossistemas e bem-estar humano;

- Seu potencial para contribuir com a redução da pobreza e o aumento do bem-estar;

- A compatibilidade das políticas públicas implantadas;

- Integração de objetivos sociais, econômicos e ambientais;

- A facilitação do gerenciamento integrado. (AM, 2005).

A Teoria dos Ecossistemas tem enfoque interdisciplinar, passando por diversos campos que abordam as questões naturais como a biologia, a 
geografia, a física e a ecologia. Quando inseridas em contexto urbano passam a abranger outras disciplinas relacionadas ao planejamento da cidade, que são a arquitetura e o urbanismo, a arquitetura da paisagem (ou paisagismo) e as engenharias. Essa interface permitiu o surgimento e novas teorias que trabalham no limiar do ambiental com o urbano e das relações entre um e outro, como a Ecologia da Paisagem e o Desenho Ambiental, que por sua vez deram origem a novos conceitos como Ecologia Urbana e Infraestrutura Verde. Baseia-se no entendimento de que homem e natureza, ambiente natural e construído, fazem parte de um todo interdependente onde os ecossistemas sofrem impactos decorrentes das ações humanas, que afetam seu funcionamento, a produção dos serviços ecossistêmicos, o bem estar humano e sua própria sobrevivência. Sobre esse assunto e sobre os serviços ecossistêmicos, trataremos adiante.

\subsubsection{SERVIÇOS ECOSSISTÊMICOS}

O entendimento de que o homem se beneficia do ecossistema vem de longa data e foi expresso em dizeres de Aldo Leopold em 1864 e George Perkins Marsh em 1949. O termo "senviços do ecossistema" é relativamente recente e foi usado pela primeira vez em 1966 quando King, preocupado com as interações ecológicas e econômicas do homem, definiu 6 valores associados à vida selvagem que seriam positivos para as pessoas, sendo estes comerciais, recreativos, biológicos, estéticos, científicos e sociais. Dessa data em diante, diversos outros estudiosos passaram a dar maior enfoque ao assunto, sendo que na década de 1990 foi dada ênfase a estimar sua valoração econômica. (ORTEGA et al., 2015). Esse desenvolvimento do conceito, ligado à sua abrangência de interesses desencadeou sua conexão à economia e diversas formas de avaliá-los em termos de valores financeiros foram criadas. Esse mercado dos serviços ecossistêmicos, que cresceu rapidamente e sem muita 
discussão crítica acabou tirando o foco da questão ambiental e os transformando em commodities. (BAGGETHUN et al., 2009).

Segundo a Avaliação Ecossistêmica do Milênio, que é considerada como ponto chave para a popularização do conceito de serviços ecossistêmicos (ORTEGA et al., 2015), estes podem ser entendidos como os benefícios que as pessoas recebem através dos processos e ciclos do ecossistema que incluem a produção de alimento, água, combustíveis, serviços de regulação do clima, das enchentes, ciclos de nutrientes, benefícios estéticos, de lazer, culturais e espirituais. Segundo a AM: "mudanças nesses serviços afetam o bem estar humano por meio de impactos na segurança, nos bens materiais necessários para uma boa vida, na saúde e nas relações sociais e culturais." (2005, p.30).

Daily tem definição muito referenciada do assunto e entende que:

"Os serviços ecossistêmicos são as condições e processos por meio dos quais os ecossistemas naturais e as espécies que os compõem sustentam e completam a vida humana. Eles mantêm a biodiversidade e a elaboração de produtos do ecossistema, como frutos do mar, madeira para forragem, combustíveis de biomassa, fibras naturais e muitos produtos farmacêuticos, industriais e seus precursores". (DAlLY, 1997 apud AM, 2005, p. 104).

Constanza ressalta que os benefícios advindos dos ecossistemas tem origem direta ou indireta:

"Os produtos dos ecossistemas (como os alimentos) e os serviços (como a assimilação de refugos) representam os benefícios que as populações humanas recebem, direta ou indiretamente, das funções dos ecossistemas." (1997, p. 253, tradução nossa).

A demanda pelos serviços dos ecossistemas, em um cenário futuro próximo, só tende a aumentar e cresce conjuntamente ao aumento da população mundial e às mudanças em seus padrões de vida. Mais gente no planeta significa maior necessidade de alimentos e água limpa, estima-se que até o ano de 2050 a população aumentará em 3 bilhões, chegando a 9 bilhões de pessoas. (GOLDMAN, 2010). O padrão de sobrevivência da sociedade pós-industrial, baseado no consumo, 
demanda cada vez mais quantidade de combustíveis, energia e matéria prima para a produção de bens de consumo e isso impacta diretamente sobre os ecossistemas e seus serviços, não considerando ou avaliando sua capacidade de suporte. (AM, 2005; ROMEIRO, ANDRADE, 2009).

Dados mostram que $40 \%$ do solo agrícola foi deteriorado pela compactação, erosão, poluição e esgotamento de nutrientes, exemplificando o uso insustentável dos recursos naturais. Mudanças na temperatura, geradas pelo aumento da produção de gases do efeito estufa, geram alterações na ecologia dos organismos e nos processos que influenciam a oferta de serviços ecossistêmicos. (ADLER, TANER, 2015). Além de ir na contramão do desenvolvimento sustentável, essas ações afetam o bem-estar humano e colocam algumas comunidades em situação de alta vulnerabilidade, potencializando o risco de secas, inundações e enfermidades, recaindo mais fortemente sobre a parcela menos favorecida da população, já que os mais favorecidos tem acesso mais facilmente à tecnologia e substitutos dos serviços ecossistêmicos. (AM, 2005).

O Conselho de Avaliação Ecossistêmica do Milênio divide os serviços do ecossistema em 4 categorias, sendo elas: serviços de abastecimento, incluindo a produção de produtos às pessoas como alimento e energia; serviços de regulação, que cuidam de regular os processos naturais como controle do clima e manutenção do ciclo da água; serviços culturais, que abrangem os benefícios relacionados ao lazer, estética e enriquecimento espiritual e serviços de apoio, que ajudam a manter os outros serviços com a formação de matéria prima, como o oxigênio. (AM, 2005).

Como colocado pela AM (2005), os serviços de abastecimento são responsáveis pela oferta de produtos ao homem como: alimentos e fibras que abrangem uma ampla oferta de produtos alimentícios derivados das plantas e animais, bem como materiais providos pelas espécies vegetais, como madeira, fibras para produção de tecidos e outro bens, que são importantes como matéria prima na construção de abrigo, móveis, roupas 
e outros produtos; combustível como madeira, biomassa e outros produtos que podem ser utilizados diretamente como energia ou indiretamente na produção da mesma; produtos bioquímicos e medicamentos naturais como as plantas medicinais e outros componentes do ecossistema que são fundamentais na composição de medicamentos e suplementos para a melhoria da saúde humana e água doce, que é elemento fundamental à vida de todas as espécies e também papel de regulação nos ciclos e processos ecossistêmicos. (AM, 2005; DAllY et al., 1997; ANDRADE, ROMEIRO, 2009; GROOT et al., 2002). Os serviçOs de abastecimento podem ser responsáveis pela base de certas economias locais, como a de comunidades pesqueiras ao longo do litoral. (COMMITTE ON ASSESSING AND VALUING THE SERVICES OF AQUATIC AND RELATED ECOSSYSTEMS, 2004).

Os serviços de regulação são responsáveis pela manutenção dos ciclos ecológicos e entre estes podemos citar o ciclo do ar e sua filtragem através da fotossíntese. Em relação ao clima, vários são os fatores que influenciam sua regulação, como cobertura do solo que afeta a taxa de precipitação e temperatura e o sequestro e emissão de gases do efeito estufa que estão relacionados ao aumento das temperaturas na Terra. A regulação do ciclo da água é outro importante serviço dos ecossistemas. Aqui os elementos dos ecossistemas são responsáveis por drenar água das chuvas, abastecer os aquíferos subterrâneos, mananciais e lençol freático e umidificar o ar. O controle de erosão é também um de seus serviços, sendo efetuado pelas plantas nas bordas de rios e morros, que os mantém estáveis. Também ajudam na filtragem das águas que percolam no solo ou que passam pelas matas ciliares e áreas de wetland. Outros serviços de regulação dos ecossistemas são o controle biológico de pragas nas colheitas, doenças do gado, controle de vetores e insetos, como a dengue, a polinização das flores que é necessária para produção de frutos, a dispersão de sementes e a proteção contra tempestades exercida por ecossistemas como os manguezais. (AM, 2005; GOLDMAN, 2010; DAILY et al., 1997; ANDRADE, ROMEIRO, 2009; GROOT et al., 2002). 
Os senviços culturais são aqueles relacionados às experiências de recreação, estéticas e espirituais que incluem valores como a diversidade cultural e sua relação com os ecossistemas locais; valores espirituais, religiosos e folclóricos associados aos ecossistemas como as lendas do boto cor de rosa e outras; a inspiração que fornecem para a arte, folclore, símbolos nacionais, arquitetura e outras atividades; valores estéticos ligados à paisagem, às árvores e às águas; herança cultural; recreação e ecoturismo que são atividades ligadas à natureza e variam conforme o tipo de bioma onde estão inseridas, contribuindo também para a saúde e bem estar humanos. Como esses valores são ligados à percepção e ao comportamento humano, variam muito conforme a cultura de cada povo e local. (AM, 2005; ANDRADE, ROMEIRO, 2009; GROOT et al., 2002).

Os serviços de apoio são aqueles que dão suporte aos demais e que são necessários para que esses aconteçam e têm impacto indireto sobre o homem, como a formação e recomposição da fertilidade do solo que é base para a produção de alimentos, para o ciclo da água e nutrientes, mas que não tem relação direta com as atividades humanas. Outros exemplos de serviços de apoio são a formação de oxigênio, o ciclo de nutrientes, o ciclo da água, a decomposição de resíduos e a manutenção da biodiversidade. (AM, 2005; DAllY et al., 1997; ANDRADE, ROMEIRO, 2009).

Algumas dessas funções, os processos ecossistêmicos que as originam e seus senviços podem ser observados na tabela 01 (GROOT, 2002). Dessa lista, 6 funções são consideradas de maior importância para as áreas urbanas: filtragem do ar (regulação de gases), regulação do micro-clima, redução de barulho (regulação de perturbações), drenagem das águas urbanas (regulação das águas), tratamento de resíduos e valores culturais e recreativos. (BOLUND, HUNHAMMAR, 1999). 


\begin{tabular}{|c|c|c|}
\hline FUNÇÃo & PROCESSO ECOSSITÊMICO & SERVIÇO ECOSSISTÊMICO \\
\hline Funções de regulação & $\begin{array}{l}\text { Manutenção de processos ecológicos essenciais e suporte dos } \\
\text { sistemas vivos. }\end{array}$ & \\
\hline Regulação do ar & Ciclos bioquímicos. & $\begin{array}{l}\text { Proteção gases UV, manutenção da qualidade do ar e } \\
\text { manutenção climática. }\end{array}$ \\
\hline Regulação do clima & Participação na cobertura do solo e nos ciclos biológicos. & $\begin{array}{l}\text { Manutenção de climas amenos que propriciam a perpetuação } \\
\text { da vida, afetando saude dos seres vivos e da vegetação. }\end{array}$ \\
\hline Prevenção distúrbios & $\begin{array}{l}\text { Influencia a estrutura do ecossistema e amortecimento de } \\
\text { distúrbios nos mesmos. }\end{array}$ & Proteção contra tempestades, alagamentos e outros. \\
\hline $\begin{array}{l}\text { Regulação do ciclo da } \\
\text { água }\end{array}$ & $\begin{array}{l}\text { Processo da cobertura da terra na regulação do escoamento } \\
\text { superficial e descarga nos cursos d'água. }\end{array}$ & $\begin{array}{l}\text { Drenagem e irrigação naturais, meio de transporte, água para } \\
\text { consumo. }\end{array}$ \\
\hline Retenção do solo & Processo da matriz de raiz da vegetação na retenção de solo. & Segurança e chão para construções. \\
\hline Formação do solo & Acúmulo de material orgânico e mineral. & $\begin{array}{l}\text { Manutenção da fertilidade do solo e dos produtos dele } \\
\text { produzidos. }\end{array}$ \\
\hline Regulação de nutrientes & Papel da biota em armazenar e reciclar nutrientes. & Manutenção da terra fértil, prevenção de erosão. \\
\hline Regulação de nutrientes & Processo da biota em estocar e reciclar nutrientes. & $\begin{array}{l}\text { Controle de poluição, filtragem do ar, controle poluição } \\
\text { sonora. }\end{array}$ \\
\hline Polinização & Movimento entre material genético vegetal. & Polinização de espécies vegetais e plantações. \\
\hline Controle biológico & Controle de população e relações trópicas. & $\begin{array}{l}\text { Controle de pestes e doenças, manutenção da diversidade } \\
\text { vegetal. }\end{array}$ \\
\hline Funções de habitat & Prover habitat para espécies animais e vegetais & \\
\hline Refúgio & Espaço apropriado para espécies vegetais e animais. & Manutenção da diversidade biológica e genética. \\
\hline Berçário & Prover habitat propício a reprodução. & Caça, pesca e colheita d efrutas. \\
\hline Funções de produção & Provisão de produtos naturais & \\
\hline Alimentos & Conversão da energia solar em plantas comestiveis e animais. & $\begin{array}{l}\text { Produtos para construção e manufatura, combustivel e } \\
\text { energia. }\end{array}$ \\
\hline Materiais naturais. & Conversão da energia solar em biomassa para usos diversos. & Combustivel. \\
\hline Recursos genéticos & Material genético e evolução. & Produtos farmaceuticos. \\
\hline Recursos medicinais & $\begin{array}{l}\text { Variedade de substâncias bioquímicas e outros usos } \\
\text { medicinais. }\end{array}$ & $\begin{array}{l}\text { Organismos de testes e ensaios, recursos para moda, jóias, } \\
\text { decoração e outros. }\end{array}$ \\
\hline Funções de informação & Provisão de oportunidades para o desenvolvimento cognitivo & \\
\hline Informaçṍes estéticas & Paisagens atrativas. & Desfrute de cenários. \\
\hline Recreação & Variedade de paisagens com usos recretaivos. & Ecoturismo, esportes e outros. \\
\hline Culturtal e artistica & Variedade de paisagens com valores culturais e artisticos. & $\begin{array}{l}\text { Uso da natureza em histórias e livros, filmes, pinturas, } \\
\text { folclore, arquitetura e outros. }\end{array}$ \\
\hline Espiritual e histórica & Variedade de paisagens com valores históricos e espirituais. & Uso da natureza para fins religiosos e históricos. \\
\hline Ciência e educação & Variedade de paisagens com valores cientificos e educacionais. & $\begin{array}{l}\text { Uso dos sistemas naturais para excursões de ewscola e } \\
\text { pesquisa científica. }\end{array}$ \\
\hline
\end{tabular}

Tabela 01. Tabela mostrando funções, processos e respectivos serviços ecossistêmicos. Adaptada de GROOT, 2002.

A economia da civilização humana depende dos serviços oferecidos gratuitamente pelo ecossistema e eles são avaliados anualmente em trilhões de dólares. (DAlLY et al., 1997). A falta de consciência desses valores por parte da civilização humana vem cada vez mais transformando ambientes naturais em sistemas dominados pelo homem, onde os ecossistemas perdem ou diminuem drasticamente sua capacidade de produção de serviços, o que acarreta na perda do bem 
estar humano e na criação de graves problemas para a sobrevivência da vida no planeta.

\subsection{DESENVOLVIMENTO SUSTENTÁVEL PARA A CIDADE RESILIENTE}

Desenvolvimento sustentável tem sido um tema muito discutido e bastante controverso, para não dizer polêmico, nos últimos anos, tendo sido utilizado por instituições e programas das mais diversas áreas e com diferentes propósitos. (KATES et al., 2005). A polêmica reside sobre a suposta indefinição e ambiguidade do significado da expressão e a possibilidade do termo ser usado mesmo não significando o todo do seu conceito e cair no lugar comum, tornando-se um clichê. (LELÉ, 1991; GIOVANNONI; FABIETII, 2014; KATES et al., 2005; GALLOPIN, 2003; MEBRATU, 1998). É um conceito controverso já que exige mudanças fundamentais no comportamento humano, nas formas de viver e principalmente de consumir e produzir, embasando-se, segundo Franco, em três princípios fundamentais:

\footnotetext{
"a conservação dos sistemas ecológicos sustentadores da vida e da biodiversidade; a garantia da sustentabilidade dos usos que utilizam recursos renováveis e manter ações humanas dentro da capacidade de carga dos ecossistemas sustentadores." (2001, p.26).
}

Sua definição mais aceita é a de 1987, do relatório denominado Nosso Futuro Comum, da WCED (Comissão Mundial sobre Meio Ambiente e Desenvolvimento), mais conhecido como Relatório Brundtland, que coloca o desenvolvimento sustentável como: "aquele que atende as necessidades presentes sem comprometer a habilidade das gerações futuras atenderem suas próprias necessidades." (BRUNTLAND, 1987, tradução nossa). Surge em um momento de crescente preocupação com os problemas ambientais e da consciência sobre a situação de super exploração dos recursos naturais e da necessidade de protegê-los para o 
bem-estar e sobrevivência das atuais e futuras gerações, como apontado no mesmo relatório:

"Muitos de nós vivemos além dos recursos ecológicos, por exemplo, em nossos padrões de consumo de energia... No mínimo, o desenvolvimento sustentável não deve pôr em risco os sistemas naturais que sustentam a vida na Terra: a atmosfera, as águas, os solos e os seres vivos." (BRUNTLAND, 1987, p42).

Apesar de estar ligado à ideia de sutentabilidade e de seus três pilares: o ambiental, o social e o econômico, o desenvolvimento sustentável é distinto deste já que desenvolvimento significa mudança de direção, processo e o movimento é contrário ao conceito de sustentabilidade, que se baseia no equilíbrio. Outro problema de má interpretação do conceito deriva do entendimento distorcido da palavra desenvolvimento, que comumente é associado ao contexto de crescimento quantitativo, priorizando a questão econômica, quando na verdade o que se busca com o desenvolvimento sustentável é a "melhora da condição humana e dos sistemas sócio ecológicos de que participam os seres humanos". (GALLOPIN, 2003). Como colocado pelo Relatório Brundtland:

\footnotetext{
"a palavra desenvolvimento tem sido reduzida por alguns a um foco muito limitado, no sentido de o que as nações pobres têm que fazer para se tornar ricas (...) meio ambiente é onde vivemos e desenvolvimento é o que todos fazemos para melhorar nossa sorte nessa morada. Os dois são inseparáveis." (WECD, 1987, tradução nossa).
}

Segundo Sartori (et al, 2014), no guarda-chuva de princípios do desenvolvimento sustentável estão fundamentos diversos como: o implemento das normas de proteção ambiental, o desenvolvimento humano, a erradicação da pobreza, o equilíbrio entre produção e consumo, o incentivo à educação, a eficiência na alocação de recursos, a cooperação entre governança e sociedade civil, a avaliação e aprimoramento permanentes, visão holística, a participação da ciência e tecnologia, entre outros. Essas colocações apresentam conteúdo holístico, 
multidimensional, com foco na equidade intergeracional e em um processo de crescimento econômico em harmonia com as demais esferas da sociedade, respeitando os princípios de preservação ambiental e justiça social. (BID, 2001; SARTORI et al., 2014).

Indo na mesma direção, a Organização das Nações Unidas (ONU), após o sucesso do programa de Avaliação Ecossistêmica do Milênio (AM), lança o programa Objetivos de Desenvolvimento do Milênio (ODM), em 2015, que estabelece 17 metas para o desenvolvimento sustentável, tendo como foco geral a garantia da vida com dignidade. Entre esses 17 princípios encontramos:

1. Erradicação da pobreza;

2. Fome zero e agricultura sustentável;

3. Saúde e bem-estar;

4. Educação de qualidade;

5. Igualdade de gênero;

6. Água potável e saneamento;

7. Energia limpa e acessível;

8. Trabalho decente e crescimento econômico;

9. Indústria, inovação e infraestrutura;

10. Redução de desigualdades;

11. Cidades e comunidades sustentáveis;

12. Consumo e produção responsáveis;

13. Ação contra a mudança global do clima;

14. Vida na água;

15. Vida terrestre;

16. Paz, justiça e instruções eficazes;

17. Parcerias e meios de implementação.

A maior parte desses princípios está prevista na Agenda 21, documento elaborado em 1992, no encontro internacional A Cúpula da 
Terra (UNCED - Conferência das Nações Unidas para o Meio Ambiente e Desenvolvimento), ou a Rio 92, onde foram estabelecidos pontos, acordados entre as nações participantes, sobre as mudanças climáticas e a biodiversidade. $\mathrm{O}$ documento reflete $\mathrm{O}$ entendimento da importância das cidades e dos processos urbanos para o desenvolvimento sustentável e estabelece conselhos e boas práticas para a conquista do mesmo. Segundo Franco (2001, p.27), os princípios expressos na Agenda 21 poderiam funcionar como um "princípio regulador dos efeitos da globalização perversa" e são base para o desenvolvimento do conceito e paradigma do desenvolvimento sustentável, que considera a ecologia inseparável da economia, como apontado por Odum (1983), em uma "íntima simbiose entre gestão ambiental e desenvolvimento econômico."

O desenvolvimento sustentável depende em grande parte da sustentabilidade das cidades. (AHERN, 2011). O cenário da cidade sustentável se apoia no desenvolvimento urbano que integra os processos sociais, econômicos, ambientais e institucionais, considerando que a cidade é formada por sistemas que se relacionam, mas que funcionam separadamente, gerando impactos sobre os demais. Como exemplo podemos citar o uso de transporte sustentável que impacta diretamente sobre a qualidade de vida e da saúde pública, diminuindo tempo de deslocamento e reduzindo emissões poluentes. (BID, 2001, p.8).

$\mathrm{Na}$ perspectiva urbana do desenvolvimento sustentável, novas teorias foram criadas, como o novo urbanismo e o crescimento inteligente. Esses pensamentos visam criar situações de equilíbrio e sustentabilidade paradoxas ao conceito de desenvolvimento, que como visto anteriomrente, prevê constante evolução. (AHERN, 2011 ). Para ajustar esse descompasso surge o conceito de resiliência urbana.

Ser sustentável é um fundamento essencial à resiliência das cidades. Por resiliência podemos definir a capacidade que um sistema tem de se reorganizar e adaptar às mudanças sofridas após disturbios. A ideia não é de voltar a um estado de pré-equilíbrio, e sim de criar novos padrões de 
funcionamento baseados em novos cenários. O conceito está ligado aos princípios de flexibilidade e adaptatividade, que nos levam a enfatizar a ideia da dinâmica, que por sua vez é fudamental ao entendimento dos sistemas naturais e também urbanos. Ambos se baseiam na dinâmica de seus elementos, em sua estrutura e funcionamento. (PICKETT et al., 2004). No urbanismo e planejamento ambiental, a resiliência requer prever como as cidades podem adequar sua estrutura e funcionamento, bem como sua capacidade de responder a esses distúrbios, prevenindo imprevistos, problemas e até catástrofes, nas esferas social, econômica e ambiental. (AHERN, 2011). Requer um tipo diferente de pensamento e planejamento, adaptável, participativo, experimental, que considera as dinâmicas específicas de cada local, integrando suas escalas. (PICKET et al., 2004).

Jack Ahern propõe 5 estratégias para o planejamento de cidades resilientes, sendo elas: multifuncionalidade; redundância e modularização; diversidade; conectividade e trabalho intraescalar; projeto e planejamento adaptativo. Para a aplicação desses princípios, muito da infraerstrutura convencional da cidade deverá ser revista e trocada por modelos mais eficientes. (AHERN, 2011). É nesse cenário que a infraestrutura verde ganha força e desponta como novo modelo de estrutura e infraesrtutura ecológica, baseada nos serviços ecossistêmicos, fundamental para a criação de cidades mais resilientes e sustentáveis. Como apontado por Niemelä:

"a abordagem ecossistêmica para o planejamento urbano, que inclui acesso equitativo aos serviços ecossistêmicos e planejamento em escalas relativas, são a chave para as cidades sustentáveis do futuro." (NIEMELÄ et al., 2011 , p. 2, traduçao nossa). 


\section{CAPÍTULO 2}

\section{ECOVILAS E BAIRROS ECOLÓGICOS}

A terminologia eco nunca foi tão usada como nos tempos atuais. A preocupação com o aquecimento global, as mudanças climáticas e a exploração dos recursos naturais tem levado a sociedade e suas organizações a buscarem novas ferramentas e saídas para o projeto do território, o que levou a frutificação de termos acompanhados do sufixo eco e dos adjetivos verde e ecológico. Ecodistritos, ecobairros, ecovilas, ecocidades, ecocomunidades, ecopolis, cidades verdes, bairros verdes, bairros sustentáveis, cidades solares, bairros zero carbono, entre outros, são alguns dos mais utilizados na literatura.

Existem hoje cerca de 178 políticas no mundo de apoio à construção desses territórios ecos (JOSs et. al., 2013), na China mais de 100 municípios tem propostas de construção de ecocidades (BAEUMIER at al., 2013) e em 2009 foram contabilizados 33 ecobairros na França. (CHARLOT; OUTREQIN, 2009). Na Europa existem cerca de 250 bairros ecológicos, dos quais 150 estão na Alemanha. (D'AVILA, 2007). Um projeto português chegou a identificar 420 ecobairros pelo mundo. (HOLDEN et. al, 2015). Novas cidades sustentáveis no meio do deserto, como Masdar, são projetadas a cada ano.

Essas terminologias e nomes acabam sendo utilizados, reservadas questões relativas à escala do espaço tratado, significando coisas diferentes, nomes diferentes também são usados para definir coisas similares, o que gera uma grande confusão de conceitos, como acontece também com o caso da sustentabilidade, citado no capítulo 1 desse trabalho, colocando a ideia dos territórios ecológicos em um patamar de descrédito e desconfiança, que carece de uma conceituação mais clara. 
Eco, ecológico e verde tem sido utilizados para adjetivar e nomear tanto projetos com foco na sustentabilidade como para os que tem um foco ambiental e conservacionaista mais elevado. De forma geral percebe-se que na Europa e Ásia os projetos denominados eco tem caráter sustentável, sendo que o modelo norte europeu, em países como a Suíça, Alemanha e Holanda enfatizam questões ambientais e no sul da Europa, França, Itália e Espanha, revitalização de edifícios históricos e patrimônio são muito importantes. (HOLDEN et al., 2015). Os projetos na América tem foco mais ambiental, não abrangendo tanto questões relativas à sustentabilidade e ao transporte coletivo, apoiando-se em preceitos ligados ao ecourbanismo e novo urbanismo ${ }^{7}$.

Não há um concenso sobre o modelo ideal para um ecobairro ou ecovila, mas de qualquer forma, cada um desses projetos são amostras importantes de experimentações que representam o desenvolvimento do urbanismo no caminho do desenvolvimento sustentável e resiliência das cidades.

\subsection{O MOVIMENTO DO ECOURBANISMO}

Os números citados acima mostram o tamanho do crescimento dos pensamentos e movimentos ligados ao ecorbanismo pelo mundo. Sua popularidade deve-se ao fato de, mesmo com divergências e certa indefinição no seu conceito, que varia entre diferentes países, culturas e instituições, tratar de um conjunto de ferramentas de planejamento e projeto que propõe um novo paradigma urbano, com maior equilíbrio entre natural e construído, mais saudável e que porporcione melhor qualidade de vida às pessoas.

O movimento emerge com base nos princípios conservacionistas da década de 1960, que tinha como objetivo limitar a destruição ambiental

${ }^{7}$ O novo urbanismo é um movimento que surge na década de 1980 nos Estados Unidos da América. 
causada pelo rápido crescimento das cidades e exploração dos recursos naturais. Essa década marca o ponto de mudança do paradigma ecológico mundial. (LÓPEZ, 2015). Descrições de formas de planejamento mais humano e compreensivo, sensível ao ambiente natural, já vinham sendo discutidas desde o início do século nas obras de Ebenezer Howard (Cidades jardim do amanhã, 1902) e posteriormente em Lewis Mumford (A rodovia e a cidade, 1964), Jane Jacobs (Morte e vida das grandes cidades americanas, 1961), Ian McHarg (Projetar com a natureza, 1969), James Lovelock (Gaia: uma nova visão da vida na Terra, 1987), Michael Hough (A forma da cidade e os processos naturais, 1989) a Ann Spirn (O jardim de granito, 1984). (LÓPEZ, 2015; HOLDEN et. al., 2015).

Manuel Ruano diz ter usado o termo ecourbanismo pela primeira vez em 1999 definindo-o como "o desenvolvimento de comunidades humanas sustentáveis, multi dimensionais, com ambientes construídos em equilibrio e harmonia". (RUANO, 1999, pg 10-11). Como teoria, abordando modos de equilibrar ecologia e urbanismo em um estilo de vida mais saudável, o conceito é creditado à Richard Register que, em 1975, juntamente a parceiros da Universidade de Berkeley, cria a organização Ecocity Builders, tendo como objetivo "reconstruir as cidades em equilíbrio com a natureza". (HOLDEN et. al., 2015; CHULA, 2014; ROSELAND, 1997). A obra Eco-city Berkeley, publicada em 1987, a criação do jornal The Urban Ecologist e a realização, a partir de 1990, da International Eco-city Conference, vem contribuir para a ampliação do campo científico do ecourbanismo e de sua divulgação pelo mundo. (CHULA, 2014).

Register recomenda, como princípios do ecourbanismo: o uso misto, o desenvolvimento compacto, a priorização do pedestre, a priorização do transporte público de massa, a restauração de ambientes naturais deteriorados, a agricultura local, a redução da poluição, a proteção dos recursos naturais, abordando também ideias de justiça social e desenvolvimento econômico. (HOLDEN et. al., 2015; ROSELAND, 1997). 
Traz consigo o ideal de mudança de estilo de vida e ideias de mudança nas formas de organização da sociedade e governança.

Segundo Akinaga:

"O urbanismo ecológico surge como uma forma de reconciliar a paisagem com a ocupação urbana, pautado pelas potencialidades e limitações dos recursos naturais. As áreas verdes não exercem a função somente do embelezamento e da melhoria da qualidade visual e ambiental, elas se transformam em verdadeiros artefatos de engenharia e elementos de uma infraestrutura verde de alto desempenho. A arborização viária ganha força $e$ escala ao conectar fragmentos de florestas urbanas $\mathrm{e}$ áreas verdes imersas no tecido urbano." (AKINAGA, 2014).

Ann Spirn (2011) coloca o urbanismo ecológico como interdisciplinar abrangendo a climatologia, hidrologia, geografia, psicologia, história, arte e como prática crucial para o futuro das cidades, pois tem as ferramentas necessárias para combater as ameaças que desafiam o futuro da humanidade e para a criação de cidade mais sustentáveis e resilientes. Como citado pela autora:

"A sobrevivência dos seres humanos como espécie depende da adaptação de nós mesmos e de nossos assentamentos em novas maneiras de sustentar a vida, moldando contextos que reconhecem conexões com o ar, a terra, a água, a vida e que nos ajudem a sentir e compreender essas conexões e as paisagens que são funcionais, sustentáveis, significativas e artísticas." (SPIRN, 1998, p.26).

Já O autor Douglas Farr, coloca O urbanismo ecológico como urbanismo sustentável (AKINAGA, 2014), definindo-o como aquele que apresenta "um bom sistema de transporte público e com a possibilidade de deslocamento a pé integrado com edificações e infraestrutura de alto desempenho", sendo que a conectividade, a compacidade e a biofilia são seus valores centrais. Sua visão tem como ponto principal o urbano, mesmo que abordando questões ambientais como a biofilia e infraestrutura verde. 
Em 2010, os professores da Universidade de Harvard, Mohsen Mostafavi e Gareth Doherty, organizaram no livro Urbanismo Ecológico, os trabalhos apresentados na conferência realizada em 2009 na mesma instituição: Urbanismo Ecológico - Cidades Alternativas e Sustentáveis do Futuro, que colocou o ecourbanismo no centro das discussões ambientais e urbanas mundiais, trazendo uma visão muito mais abrangente sobre seu conceito e divulgando diversos trabalhos e ideias relativos à temática que vem sendo desenvolvidos em vários países. Os autores propõem que "a associação entre ecologia e urbanismo pode fornecer o conhecimento, os métodos e as pistas sobre o que $O$ urbanismo pode vir a ser nos próximos anos" (MOSTAFAVl; DOHERTY, 2010). Abordam conceitos como a interdisciplinaridade, diversidade de escalas, uso consciente dos recursos naturais e eficiência energética em novos modelos e em um novo pensar criativo que exigem uma nova sensibilidade e que acomodem os conflitos existentes entre ecologia e urbanismo. A tabela 02 , a seguir, mostra a reunião dos parâmetros colocados pelos autores citados nesse capítulo.

Com base nesses novos paradigmas, surgem modelos e conceitos relativos a ecocidades, ecobairros e ecovilas, ecomodelos relativos a diversas escalas do urbano, todos carregando conceitos referentes a tecnologia verde, desenvolvimento econômico social, ecologia humana, bioregionalismo, projetos focados na escala do pedestre, participação comunitária e desenvolvimento sustentável.

As ecovilas e os ecobairros surgem devido a busca de uma outra forma de vida, mais próxima à natureza e com o desejo de maior integração entre a comunidade. Inicialmente, muitos projetos foram criados por comunidades hippies e grupos espirituais em busca de uma maior conexão com a terra e a natureza. Na Alemanha, país onde a prática de ecourbanismo é muito difundida, as primeiras intervenções ocorreram na década de 1980 e visavam a sustentabilidade da fase completa da obra. Nesse país, as comunidades ecológicas geralmente tem economia coletiva, forte senso de grupo e sociedade, produção 
própria de alimentos e uso de tecnologias verdes como energia limpa, reciclagem e reuso. (D'AVILA, 2007; BEATLEY, 2012). Na China, surgem como novas ocupações, geralmente nas franjas urbanas, com questões ambientais de preservação e infraestrutura verde como prioritárias. Nos Estados Unidos e Canadá, mesclam questões relativas ao ambiental e urbano, com grande influência dos conceitos de crescimento inteligente e cidade compacta, sendo aplicados para restauração de bairros degradados e terrenos contaminados ou para proteção de áreas verdes. (GIRLING; KELLETT, 2005).

\begin{tabular}{|c|c|c|c|c|c|c|}
\hline \multirow{9}{*}{ 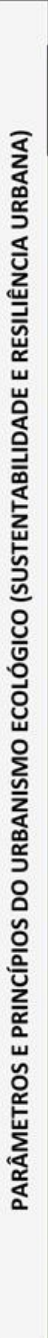 } & \multicolumn{6}{|c|}{ AUTOR } \\
\hline & DOUGLAS FARR & PATRÍCIA AKINAGA & ANN SPIRN & $\begin{array}{l}\text { MOHSEN MOSTAFAVI } \\
\text { GARETH DOHERTY }\end{array}$ & TIMOTHY BEATLEY & $\begin{array}{l}\text { CYNTHIA GIRLING } \\
\text { RONALD KELLETT }\end{array}$ \\
\hline & $\begin{array}{l}\text { Aumento da } \\
\text { sustentabilidade } \\
\text { por meio da } \\
\text { densidade urbana. }\end{array}$ & Densidade. & $\begin{array}{l}\text { As cidades são } \\
\text { parte do mundo } \\
\text { natural. }\end{array}$ & $\begin{array}{l}\text { Interdisciplinaridade, } \\
\text { adaptabilidade, } \\
\text { flexibilidade, } \\
\text { perspectiva holística e } \\
\text { planejamento } \\
\text { participativo. }\end{array}$ & $\begin{array}{l}\text { Mobilidade } \\
\text { sustentável. }\end{array}$ & $\begin{array}{l}\text { Planejar a floresta } \\
\text { urbana como elemento } \\
\text { do sistema de áreas } \\
\text { verdes que contribui } \\
\text { para a manutenção do } \\
\text { ciclo hidrológico. }\end{array}$ \\
\hline & $\begin{array}{l}\text { Corredores de } \\
\text { sustentabilidade. }\end{array}$ & $\begin{array}{l}\text { Corredores } \\
\text { sustentáveis. }\end{array}$ & $\begin{array}{l}\text { Cidades são } \\
\text { hábitats. }\end{array}$ & $\begin{array}{l}\text { Projetar de acordo com } \\
\text { a escala do espaço. }\end{array}$ & $\begin{array}{l}\text { Cidades } \\
\text { caminháveis. }\end{array}$ & $\begin{array}{l}\text { Diversidade de usos e } \\
\text { ofertas de } \\
\text { oportunidades. }\end{array}$ \\
\hline & $\begin{array}{l}\text { Bairros } \\
\text { sustentáveis. }\end{array}$ & Bairros ecológicos. & $\begin{array}{l}\text { Cidades são } \\
\text { ecossistemas. }\end{array}$ & $\begin{array}{l}\text { Ecologia projetiva- } \\
\text { trabalhar com os } \\
\text { processos naturais. }\end{array}$ & $\begin{array}{l}\text { Mudanças climáticas } \\
\text { e energia renovavel. }\end{array}$ & Priorizar o caminhar. \\
\hline & Biofilia. & $\begin{array}{l}\text { Espaços livres, } \\
\text { elementos de } \\
\text { infraestrutura verde. }\end{array}$ & $\begin{array}{l}\text { Ecossistemas } \\
\text { urbanos são } \\
\text { conectados e } \\
\text { dinâmicos. }\end{array}$ & $\begin{array}{l}\text { Ambientes urbanos } \\
\text { produtivos. }\end{array}$ & Cidades biofilicas. & $\begin{array}{l}\text { Crescimento compacto } \\
\text { e densidade. }\end{array}$ \\
\hline & $\begin{array}{l}\text { Edificação e } \\
\text { infraesrtutura } \\
\text { urbana de alto } \\
\text { desempenho. }\end{array}$ & $\begin{array}{l}\text { Edifícios verdes e } \\
\text { infraestrutura de } \\
\text { alto desempenho. }\end{array}$ & $\begin{array}{l}\text { Cada cidade tem } \\
\text { uma estrutura } \\
\text { profunda ou um } \\
\text { contexto } \\
\text { duradouro. }\end{array}$ & $\begin{array}{l}\text { Densidade como } \\
\text { padrão determinante. }\end{array}$ & Governança verde. & $\begin{array}{l}\text { Preservar manchas } \\
\text { verdes e árvores de } \\
\text { grande porte. }\end{array}$ \\
\hline & & & $\begin{array}{l}\text { O desenho } \\
\text { urbano é } \\
\text { ferramenta } \\
\text { poderosa de } \\
\text { adaptação. }\end{array}$ & $\begin{array}{l}\text { Edifícios e sistemas de } \\
\text { infraestrutura de alto } \\
\text { desempenho que } \\
\text { funcione junto à } \\
\text { natureza - } \\
\text { infraestrutura } \\
\text { ecológica/verde. }\end{array}$ & $\begin{array}{l}\text { Metabolismo urbano } \\
\text { sustentável: cidades } \\
\text { como sistemas e } \\
\text { fluxo de matérias e } \\
\text { recursos. }\end{array}$ & \\
\hline & & & & $\begin{array}{l}\text { Respeito à cultura e } \\
\text { identidade local. }\end{array}$ & & \\
\hline
\end{tabular}

Tabela 02. Lista de parâmetros e princípios do urbanismo ecológico segundo autores tratados no capítulo. 
Como dito no capítulo 1 desse trabalho, a ecologia contemporânea enfatiza as ideias de mudanças e processos (SPIRN, 2011) e esse entendimento é fundamental para o desenvolvimento do conceito de ecourbanismo ou urbanismo ecológico, que concebe a cidade como parte da natureza. Ele acredita que quando o homem constrói a cidade, gera interferências nos processos naturais e como resposta a esses distúrbios podemos ter resultados positivos ou negativos. É aí que está a semente do Urbanismo Ecológico, no trabalhar as cidades, a forma e os processos urbanos em consonância com os processos da natureza, gerando respostas sempre positivas e obtendo as melhores performances dos dois sistemas, que trabalharão não mais como concorrentes, mas como parceiros.

\subsection{BAIRROS ECOLÓGICOS}

Os ecobairros surgem como modelo que busca uma resposta aos desafios ambientais, econômicos, sociais e que propiciem a criação de ecocidades (BASCH, 2016), podendo apresentar-se como alternativa viável para os problemas relativos à alimentação, transportes, habitação e infraestrutura urbana enfrentados pelas grandes cidades do século XXI. Silva (2013) coloca as cidades como "parasitas do ecossistema" e acredita que os ecobairros podem contribuir para a reversão desse quadro e, assim como Chula (2014), que são fundamentais para reduzir a pegada ecológica das cidades.

\subsubsection{Definição de bairro ecológico}

Bairro é o lugar onde as pessoas vivem e o ambiente mais possível de ser influenciado pelas decisões de seus habitantes. Geralmente são definidos como os blocos que formam as cidades. Abriga a ocupação 
diária das pessoas, deve apresentar distâncias convenientes para caminhar, fazer as comprar diárias, levar as crianças à escola. São áreas altamente identificáveis da cidade, que as pessoas referenciam como o lugar onde vivem, trabalham, estudam ou vão se divertir. (GIRLING; KELLET, 2005, BARTON, 2000).

O modelo de bairro, ou unidade de vizinhança, mais reconhecido pelo urbanismo moderno é o de Clarence Perry, de 1929. Perry coloca que o bairro deve ter cerca de 648.000 m2 (160 acres), população suficiente para abrigar uma escola infantil (com localização central na área). 10\% da área deve ser reservada a pequenos parques e áreas de recreação que devem estar locadas, assim como a escola, à distância caminhável a todos seus moradores. Os limites do bairro devem ser marcados por grandes avenidas, para que estas não atrapalhem a circulação das pessoas no seu interior, que possui ruas menores e com menor tráfego de veículos, como mostra a figura 05 . O modelo de bairro de Perry influenciou a criação de um padrão nacional de planejamento, nos Estados Unidos da América, que perdurou até o final do século XX. (GIRLING; KELLETT, 2005, AKINAGA, 2014).

Alguns anos adiante, em 1997 no Congresso do Novo Urbanismo, no mesmo país, Andres Duany e Elizabeth Plater-Zyberk, do escritório americano DPZ, propõem uma alteração do modelo de Perry. Eles propõem comércio, serviços e instituições não apenas no centro, mas próximos a uma parada do trânsito, com apartamentos e lojas em suas maiores intersecções, aumentando a densidade e diversificando o comércio nos bairros. Ruas interiores mais estreitas, ruas de uso misto com comércio, instituições em locais de destaque, escolas nas extremidades para que possam atender também a vizinhança próxima e uma área de lazer infantil em cada quadra, como é possível observar na figura 06. Nesse modelo, o bairro é desenhado para permitir sua extensão. (GIRLING; KELLET, 2005). O modelo da DPZ foi considerado, na época, como uma melhoria em relação ao anterior, mas para as questões discutidas nesse 
trabalho, ainda carece de alternativas ambientais, e como dito no início desse capítulo, os bairros ecológicos vem atender a essas falhas.

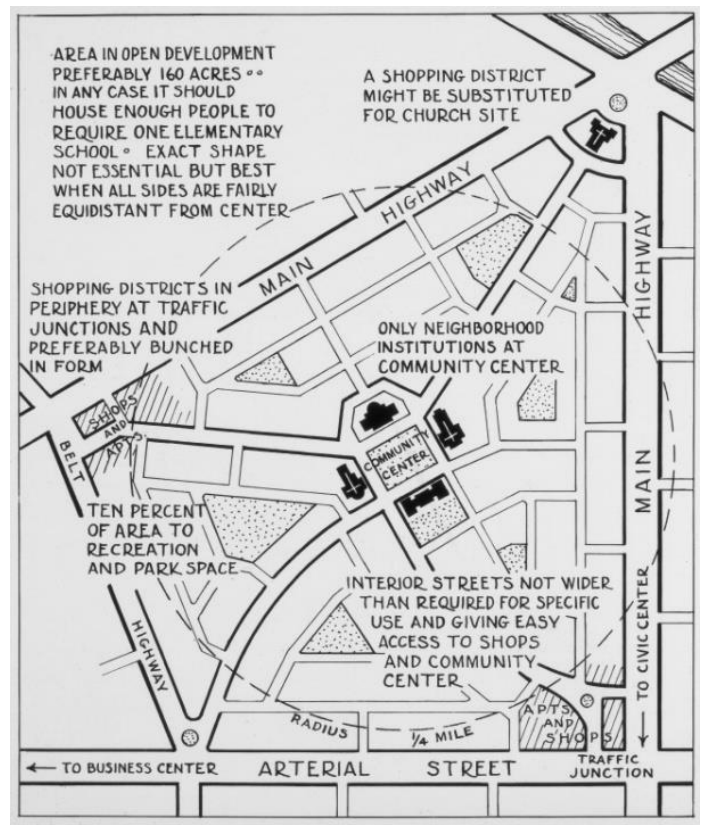

Figura 05. Modelo de bairro de Perry onde a linha tracejada marca 0 raio de caminhada de 5 minutos. Fonte: Gunderson Planning and Design, 2017.

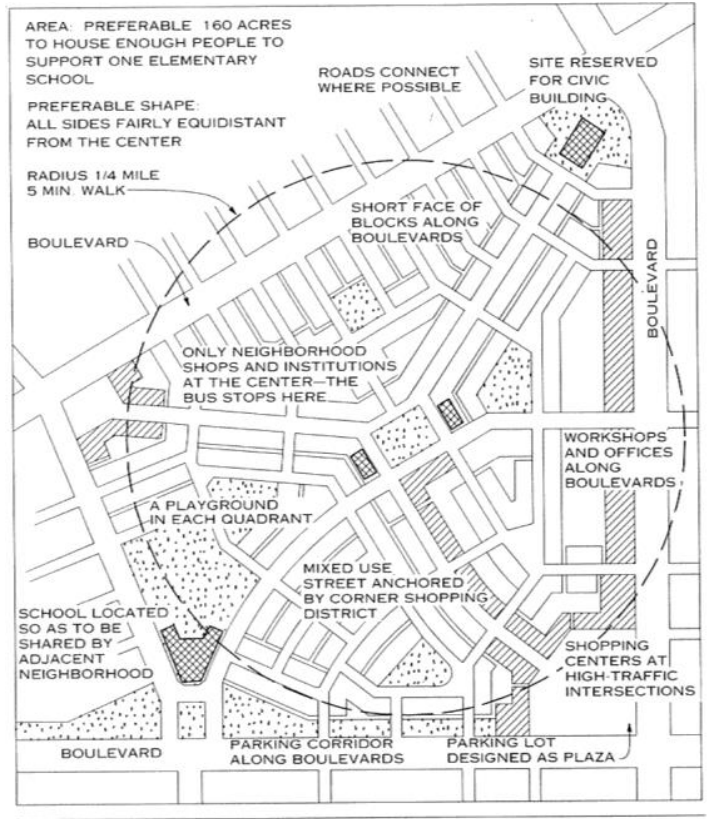

Figura 06. Modelo de bairro da DPZ onde a linha tracejada marca 0 raio de caminhada de 5 minutos. Fonte: Placemakers, 2017.

Em 2013, Farr propõe uma revisão desses modelos com o acréscimo de elementos de ecologia urbana e infraestrutura verde, resultando em um modelo com 5 diferenças em relação aos modelos anteriores: o bairro é baseado em um corredor de transporte público; a parada central proposta pela DPZ é substituída por um multimodal de transporte; é utilizada infraestrutura de alto desempenho; há mistura de usos e de densidades e os limites do bairro são definidos por corredores verdes de habitat. (FARR, 2013). Esses pontos podem ser vistos na figura 07.

Em 2010, Andrés Duany propõe novas diretrizes para a criação de bairros que possuem muitas características encontradas nos bairros ecológicos já implantados na Europa, Ásia e América do Norte e poderiam formar uma base inicial de princípios para a formação de comunidades ecológicas. São elas: preservação e celebração da natureza, preservação da arborização urbana, valorização dos mirantes, redução de corte e 
aterro no solo, manutenção do ciclo de chuvas, preservação das áreas úmidas e das águas urbanas, criação de parques, pocket parks, jardins comestíveis e corredores ecológicos. Para as questões não ecológicas desses bairros prevê uso misto, diversidade de oferta de moradia, oferta de trabalho próximo à moradia, escolas e instituições, serviços de suporte a vida cotidiana, aumento da densidade, criação de espaços abertos e produção de alimentos, comunidades abertas e estrutura orientada no trânsito (TOD).

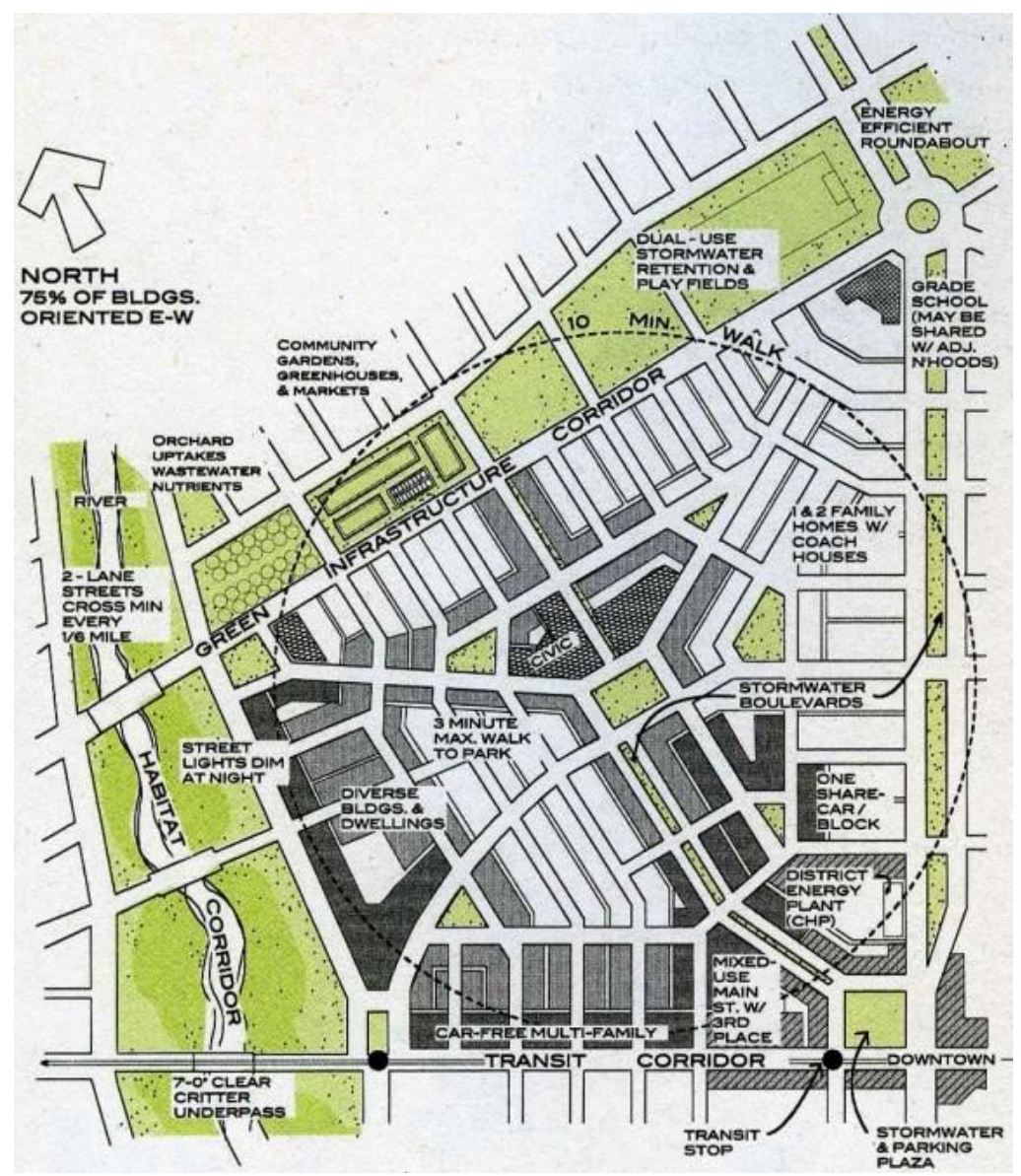

Figura 07. Modelo de bairro de Farr, onde a linha tracejada marca o raio de caminhada de 5 minutos. Fonte: Better Cities and Towns, 2017.

As diretrizes propostas por Duany vão de encontro aos objetivos dos bairros ecológicos, que são promover maior qualidade de vida em comunidades mais humanas que respeitem o meio ambiente e os recursos naturais. Roseland (1997) coloca que o movimento gerado pelos 
Ecocity Builders de Berkeley, que ficou conhecido como Ecologia Urbana, tinha a missão de criar comunidades ecológicas que seguissem esses 10 princípios (Urban Ecology, 1996):

1. Revisão das prioridades de uso do solo para criar comunidades compactas, diversas, verdes, seguras, agradáveis e vivas, próximas a pontos importantes do trânsito e de transporte;

2. Revisão das prioridades de transporte para favorecer o caminhar, as bicicletas e outras modalidades verdes de transporte não motorizado priorizando o acesso pela proximidade de localização dos serviços;

3. Restaurar os ambientes urbanos degradados, especialmente córregos, praias e áreas úmidas;

4. Criar oferta de habitação diversificada e acessível em comunidades seguras e democráticas;

5. Fomentar a justiça social criando oportunidades para os menos favorecidos, mulheres e pessoas com deficiência;

6. Apoiar a agricultura local, projetos de ecologia urbana, jardins e hortas comunitárias;

7. Promover a reciclagem, inovação da tecnologia e conservação dos recursos reduzindo a poluição e os descartes;

8. Trabalhar com empresas no sentido de promover atividades econômicas ecológicas que desencorajem o desperdício, o descarte de poluentes e uso de materiais contaminantes;

9. Promover a simplicidade e o combate ao consumo excessivo;

10. Encorajar a percepção e valoração do meio ambiente local através de projetos e atividades educacionais que aumentem o entendimento sobre questões ligadas à sustentabilidade.

Essa é a lista mais divulgada e conhecida que coloca uma definição do que um bairro ecológico deve ter, podendo perceber-se que seus princípios são seguidos pelos preceitos de Duany colocados acima. Algumas outras definições de bairro ecológico estão disponíveis na literatura científica, mas todas giram em torno, e muitas fazem referência, 
a lista de Roseland aqui apresentada. Soares e Langner (2014), o considera como exemplo de boa prática de desenvolvimento sustentável que busca "o baixo impacto social e a autossustentabilidade através da geração de trabalho, conforto, saúde e educação." Bach (2016), o coloca como projeto multidisciplinar e complexo que procura responder aos desafios do desenvolvimento sustentável.

Roseland (1997) aponta a unidade social como primordial para 0 desenvolvimento de ecobairros, sua escala mais humana, com assentamento baseado na sustentabilidade, equilíbrio ecológico e democracia própria. Basch (2016) coloca o aspecto social como chave do sucesso para o desenvolvimento de bairros ecológicos. D'Avila (2007), desenvolvendo estudos de caso nas cidades alemãs, aponta que o envolvimento com a criação e manutenção de projetos de comunidades ecológicas inclui "processos participativos e pedagógicos, mudança de hábitos e costumes".

Segundo López (2015), as experiências com diferentes ecobairros distinguem-se devido a divergências em suas escalas e também às características de seu modelo. Bairros menores possibilitam maior envolvimento da população em sua gestão do que os de maior escala. Modelos criados através da restauração de comunidades degradadas também apresentam características diferentes dos que são criados do zero.

Ainda em relação à escala e forma de organização, os ecobairros se diferenciam das ecovilas, pois por tratarem de uma escala maior de intervenção, estão mais focados em questões urbanas, ambientais, de infraestrutura e menos ligados a questões ligadas à autogestão e economia coletiva. Algumas questões são decididas em comum, mas elas geralmente dizem respeito apenas às áreas comuns dos empreendimentos e mesmo assim, apenas quando estas são comportadas pela escala do mesmo. 
Nos dois estudos de caso analisados a seguir, Vauban, já implantado na cidade de Freiburg, Alemanha e SW Ecodistrict, projeto em desenvolvimento na cidade de Washington D.C., capital americana, os conceitos colocados acima são tratados de forma com que se adaptem à escala, objetivos e contextos locais de cada lugar, focando na construção de espaços mais humanos, eficientes, que ofereçam maior qualidade de vida a seus usuários e que respeitem o limite de suporte dos ecossistemas locais.

\subsubsection{Vauban - Freiburg (Alemanha)}

No sudoeste do país, próximo à divisa com a Suíça, está o bairro de Vauban, localizado na cidade de Freiburg. Pioneira na produção de energia renovável, especialmente solar, modos de transporte coletivo e planejamento ambiental, Freiburg é reconhecida mundialmente como líder global de desenvolvimento sustentável, possuindo diversos bairros ecológicos como Rieselfeld, Wiehre Bahnhof e Vauban, que será apresentado nesse capítulo. (BEATLEY, 2012)

O terreno de 42 hectares, antigamente ocupado pelo exército francês, foi comprado pela cidade que, em 1992, lançou um concurso para o desenvolvimento do plano geral de Vauban, que pode ser visto na figura 08. O concurso tinha certas exigências, de caráter ecológico, econômico, social e cultural, prevendo que o bairro devesse ser implantado de forma participativa. Para garantir a articulação entre governança e comunidade foi criado o Fórum Vauban, uma organização não governamental que coordenou o processo de participação popular. (BEATLEY, 2012; SILVA, 2013).

O projeto previa a acomodação de 5.500 habitantes e 600 postos de trabalho, teve início em 1998 e foi finalizado em 2010. Em sua construção participaram instituições ligadas à cidade e ao governo federal, grupos privados e cooperativas de moradores. (BEATLEY, 2012; 
SILVA, 2013; SCHEURER, 2001). Como elementos chave do projeto e determinantes de seu sucesso podemos colocar seu conceito inovador de mobilidade, a eficiência energética, as diretrizes urbanas de uso misto, compacto e a participação pública em todo o processo de planejamento. (SILVA, 2013).

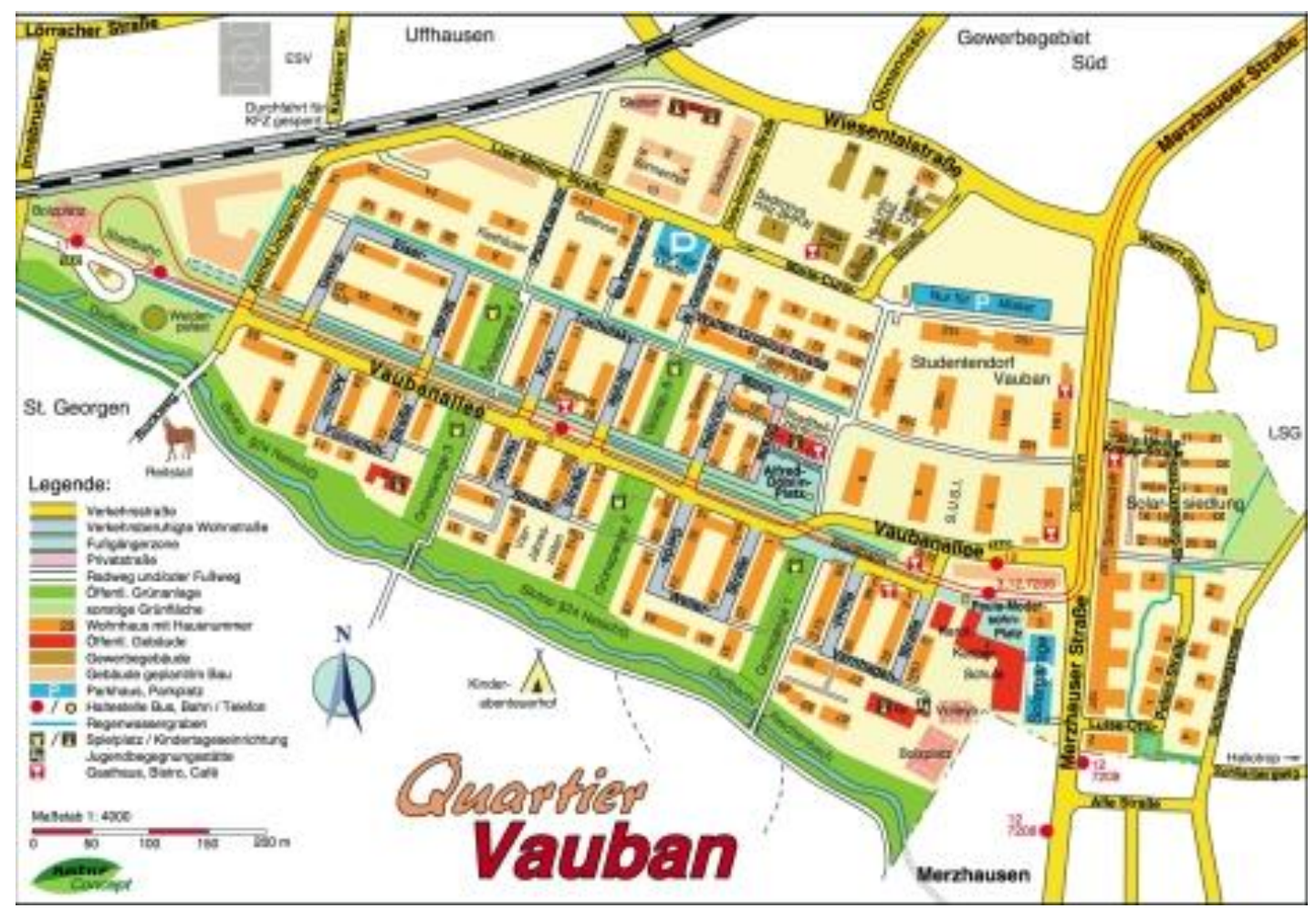

Figura 08. Plano geral de Vauban. Fonte: Always Greener, 2009.

A estratégia relativa à mobilidade teve foco no movimento cidade sem carro, tornando o uso de alternativas sustentáveis mais interessantes do que o uso do automóvel. Para atingir esse objetivo foi implantada, anterior à finalização do projeto, uma linha de VLT (veículo leve sobre trilhos) que liga o bairro ao centro de Freiburg, a $3 \mathrm{~km}$ de distância. (figura 09). (SCHEURER; NEWMAN, 2006; SILVA, 2013). Outra alternativa foi a implantação de uma estação de veículos compartilhados que, em parceria com a companhia de transportes públicos locais, ofereceu desconto aos moradores. Em relação aos automóveis particulares, adotou-se um tipo de estacionamento coletivo nas áreas periféricas do 
bairro, desincentivando o uso do mesmo pelos moradores. $O$ uso desse estacionamento está vinculado à compra da vaga e a uma taxa mensal de uso do mesmo. (SILVA, 2013, BEATLEY, 2012).

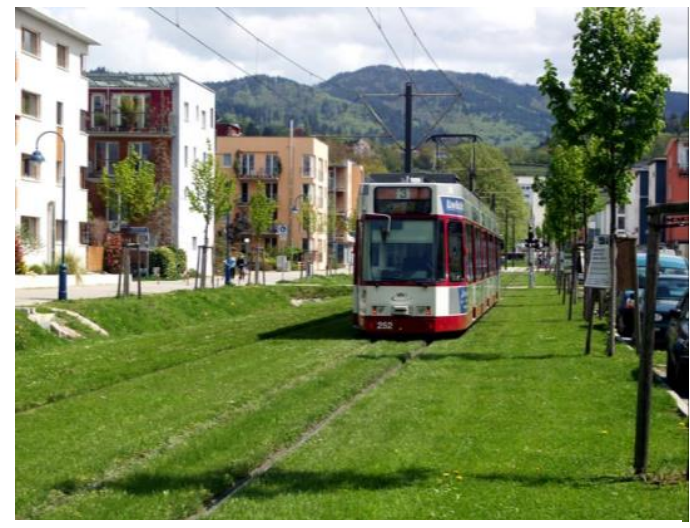

Figura 09. Linha de VLT de Vauban sobre chão gramado que permite a infiltração das águas no solo. Fonte: Tramtom, 2017.

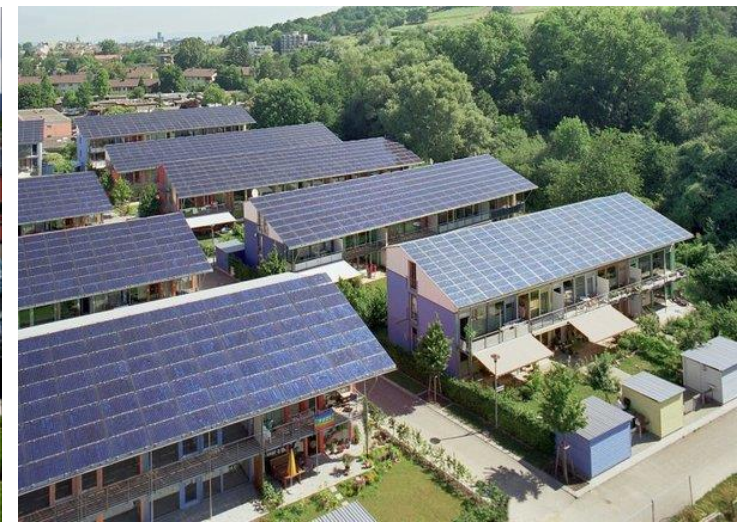

Figura 10. Placas solares sobre a cobertura das residências. Fonte: Solaripedia, 2017.

Os altos padrões de eficiência energética foram alcançados mediante $\mathrm{o}$ uso de estratégias que unem tecnologia de ponta e boas práticas da arquitetura bioclimática. Para a produção de energia foi utilizado um sistema de produção combinado de calor, abastecido a base de resíduos florestais e a utilização extensiva de placas de captação de energia solar. (SILVA, 2013). Os edifícios foram obrigados a cumprir com o código de eficiência de energia local que estabelece o consumo máximo de $65 \mathrm{kWh} / \mathrm{m} 2$ por ano. Para atingir esses objetivos, as residências e edifícios se utilizam de placas solares e sistema de ventilação inteligente com recuperação de calor fazendo uso da aplicação de vidros triplos, bom isolamento térmico e setorização sul dos ambientes de maior utilização, como mostra a figura 10. (SCHEURER; NEWMAN, 2006).

O bairro também oferece diversificada oferta de moradia, parte desta subsidiada pelo governo e também cohousing para 1.200 residentes, com áreas de lazer compartilhadas, como é possível observar na figura 11. Possui acesso a comércio e diversos tipos de senviços, uso misto, escolas e áreas de recreação. A preservação dos espaços naturais 
foi valorizada e o sistema de drenagem natural, ilustrado na figura $12 \mathrm{com}$ as biovaletas laterais às ruas, interligado à rede de sistema de águas pluviais naturais de Rigolden-Mulden. (BEATLEY, 2012). Foram preservadas as árvores mais antigas da área e criados miniparques entre as edificações (figura 13) que, além de oferecer espaços de lazer aos moradores, contribuem com o escoamento superficial e infiltração das águas. (HERZOG, 2013).

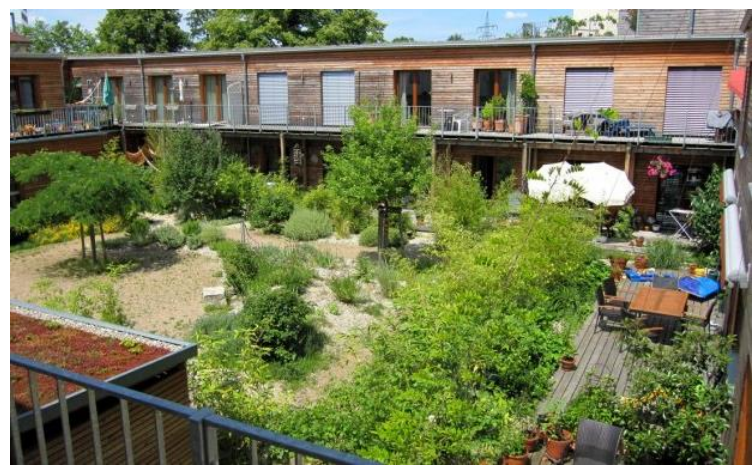

Figura 11. Área de lazer interior às quadras das cohousings ou moradias compartilhadas. Fonte: Pinterest, 2017.

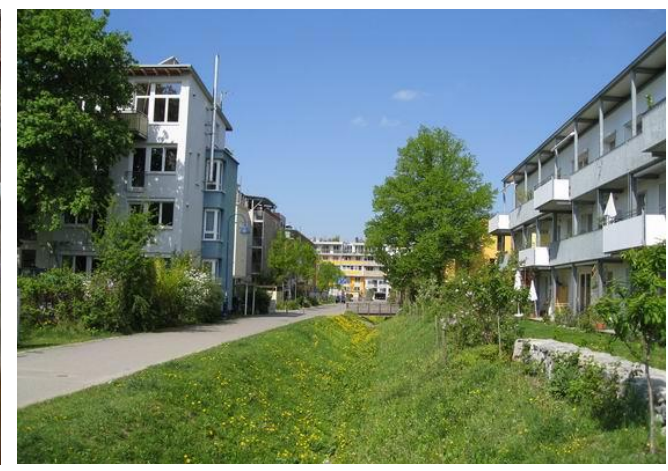

Figura 12. Biovaletas de drenagem natural. Fonte: Pinterest, 2017.

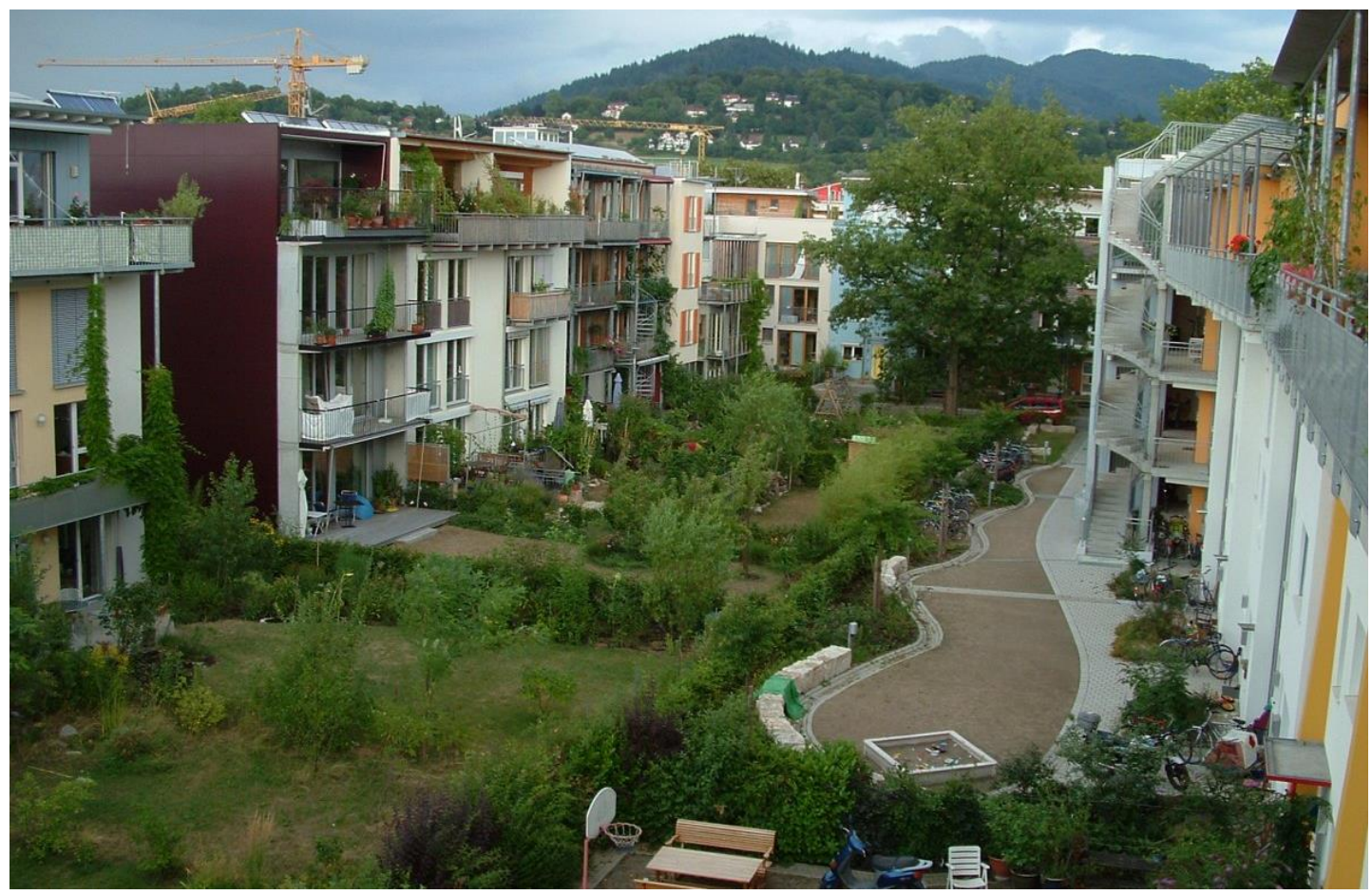

Figura 13. Pequeno parque entre edifícios residenciais enaltecendo o caráter coletivo e a vida em comunidade. Fonte: Making Lewes Organization, 2014. 
O sistema viário teve suas ruas locais estreitadas, diminuindo assim a velocidades dos automóveis e priorizando o tráfego de bicicletas (figura 14). Também foram implantadas woonerfs, que são ruas onde "pedestres, ciclistas e automóveis convivem em harmonia sem a necessidade do desenho normal que separa leito carroçável e passeio por meio de guias em desnível." (HANNES, 2016). As woonerfs estão ilustradas na figura 15, onde é possível avistar a placa azul que marca o uso especial da rua. Hoje o bairro é tido como um dos mais populares da região é reconhecido mundialmente como bairro ecológico de sucesso, tendo sido já referido como o bairro mais sustentável do mundo.

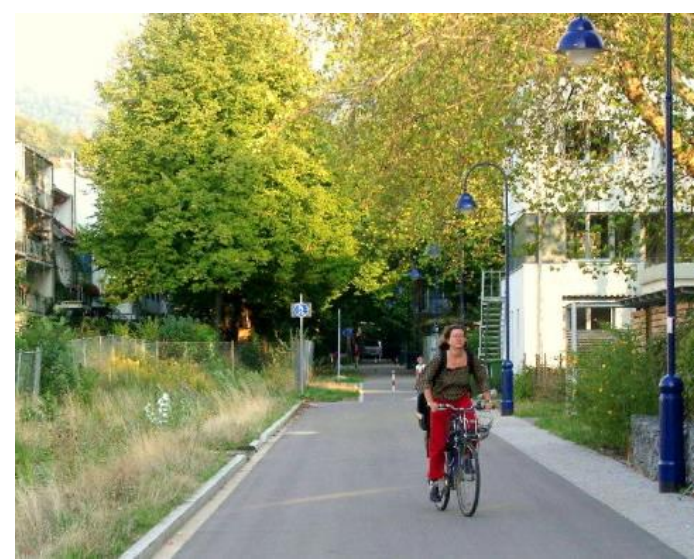

Figura 14. Ciclista nas ruas de Vauban. Fonte: Sustentarqui, 2017.

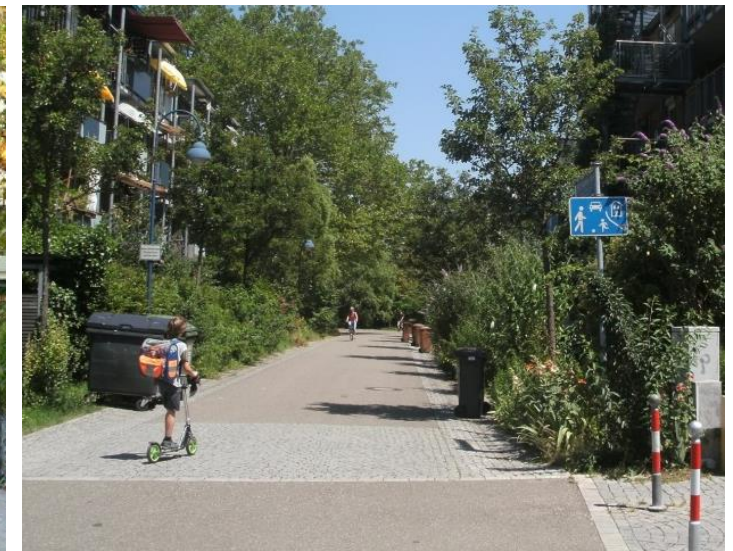

Figura 15. Woonerf com sua característica sinalização em azul. Fonte: Cycling christ church, 2015.

Analisando o projeto de Vauban em relação à tabela 02, que mostra os princípios do planejamento ecológico, podemos perceber que ela atende a quase todos esses princípios, marcados em verde na tabela 03. Isso acontece apenas porque as questões naturais não são a tônica do projeto, que foca em questões de energia limpa e mobilidade sustentável. Se trabalhados melhor esses pontos, relativos a ecologia urbana, poderíamos dizer que Vauban é exímio exemplo do que chamamos conceitualmente de bairro ecológico, onde seus princípios podem ser utilizados como modelo de boa prática para as outras comunidades. 


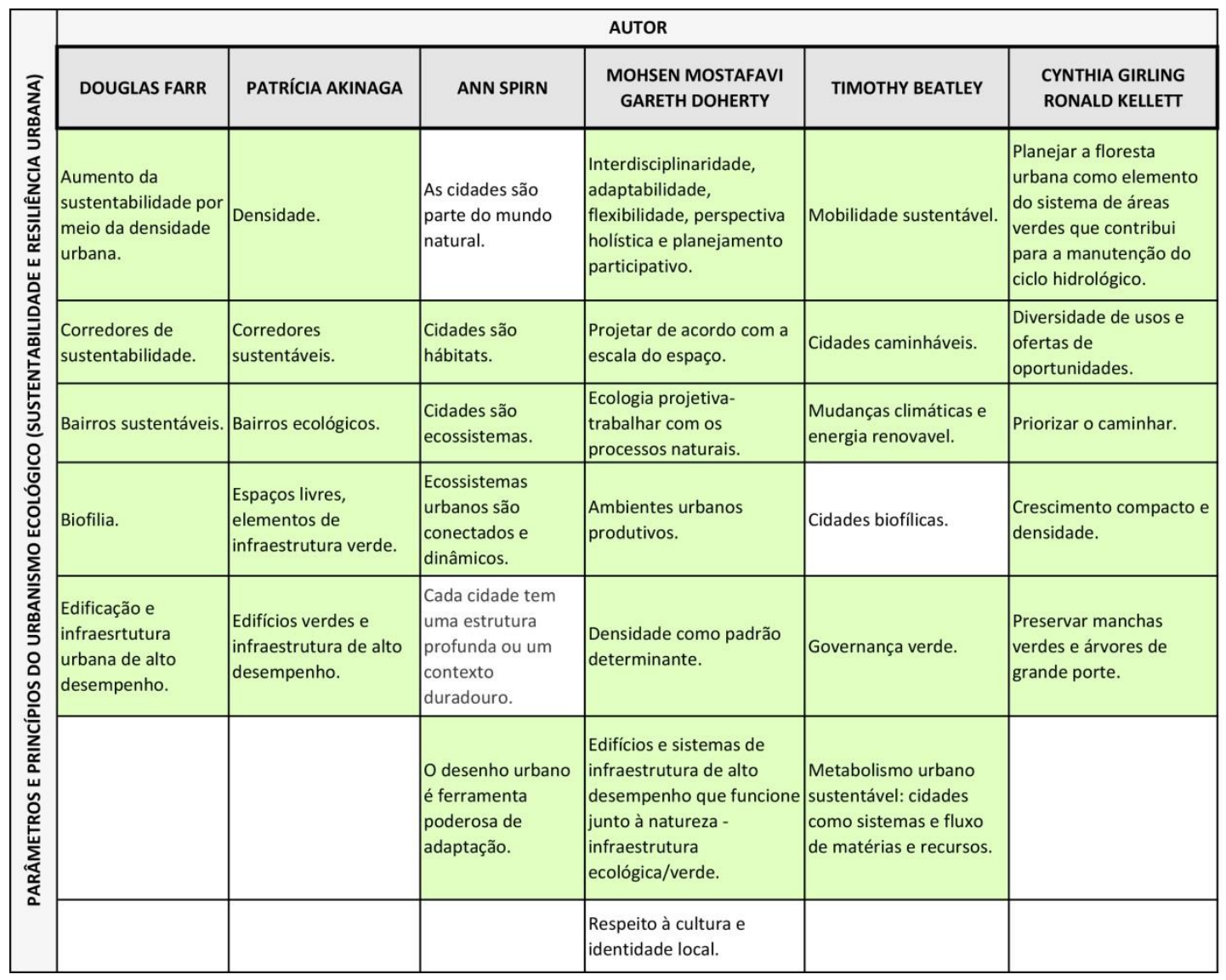

Tabela 03. Tabela dos princípios do urbanismo ecológico mostrando em verde os pontos atendidos no projeto de Vauban.

\subsubsection{Southwest Ecodistrict - Washington D.C. (EUA)}

O projeto do Southwest Ecodistrict, está localizado na cidade de Washington D.C. junto ao centro do governo americano, em uma área de enorme valor cívico de 445 mil m2, ou 110 acres, contendo 15 quarteirões, 8 edifícios federais, 8 edifícios privados e 3 parques federais. As informações fornecidas abaixo foram retiradas do Plano Oficial divulgado pela Comissão de Planejamento Nacional no ano de 2013. (NATIONAL CAPITAL PLANNING COMISSION, 2013).

O plano denominado de SW Ecodistrito: um plano visionário para um futuro mais sustentável, nasceu da parceria criada, no ano de 2010, entre organizações federais, privadas e a Comissão de Planejamento Nacional, que pretendia avaliar como transformar o corredor da Av. Maryland e da 
Rua 10 em uma comunidade de uso misto, vibrante e sustentável através da utilização de infraestrutura, edifícios e paisagismo de alta performance. O plano também pretende tornar o bairro um destino cultural e turístico, bem conectado com o entorno. O plano geral da proposta pode ser visto na figura 16 e a melhoria prevista após implantação do mesmo na figura 17 do plano original.

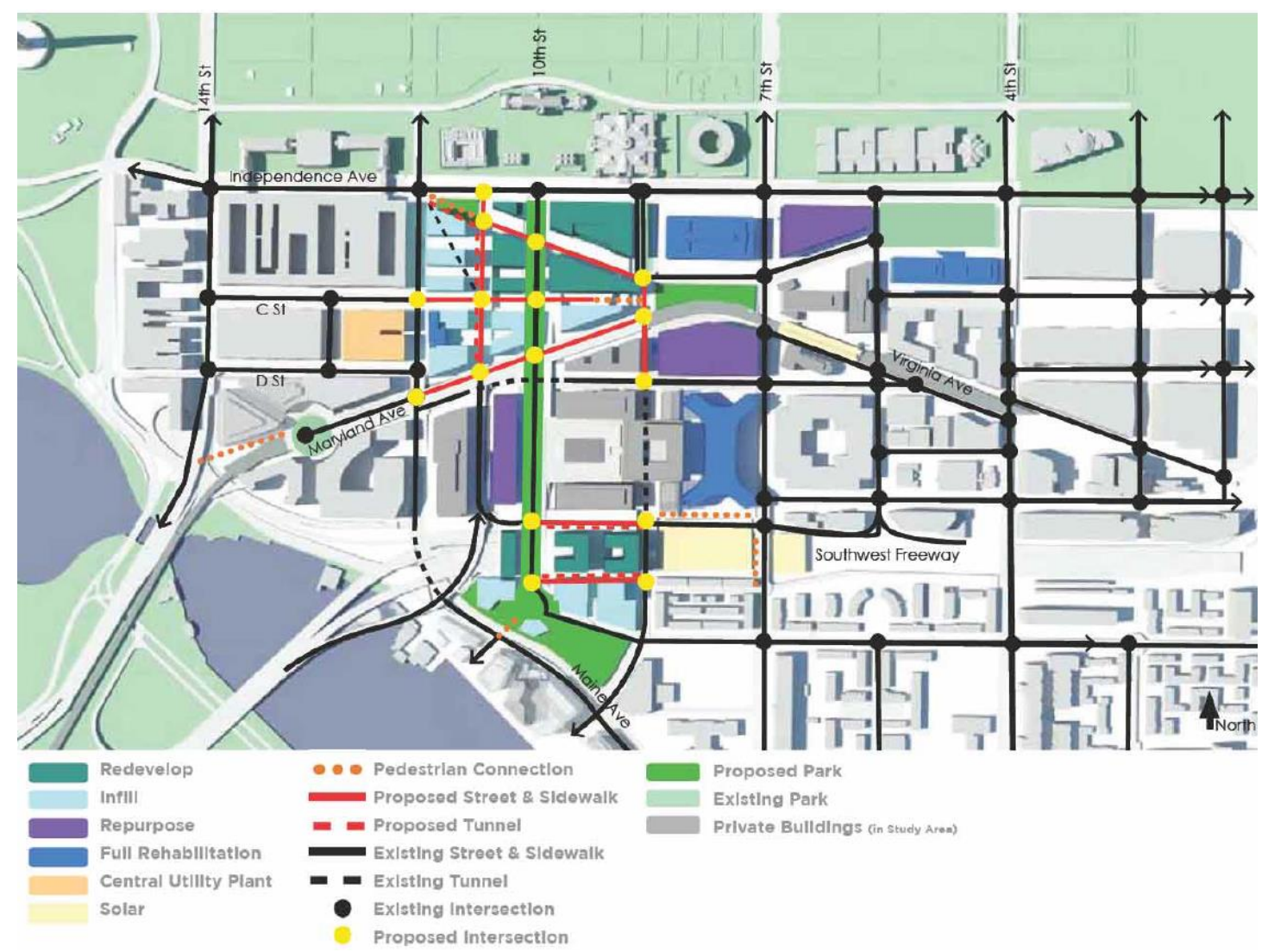

Figura 16. Plano geral da proposta de intervenção para o Ecobairro de Southwest, Washington D.C. Fonte: National Capital Planning Comission, 2013.

A estratégia em relação ao uso do solo consiste em manter o espaço de segurança federal, aumento sua densidade e acomodando usos culturais, educacionais, residenciais, comerciais e hoteleiro, criando uso mais misto e trazendo vitalidade ao bairro através da instalação de fachada ativa nesses edifícios, como mostra a figura 18. 


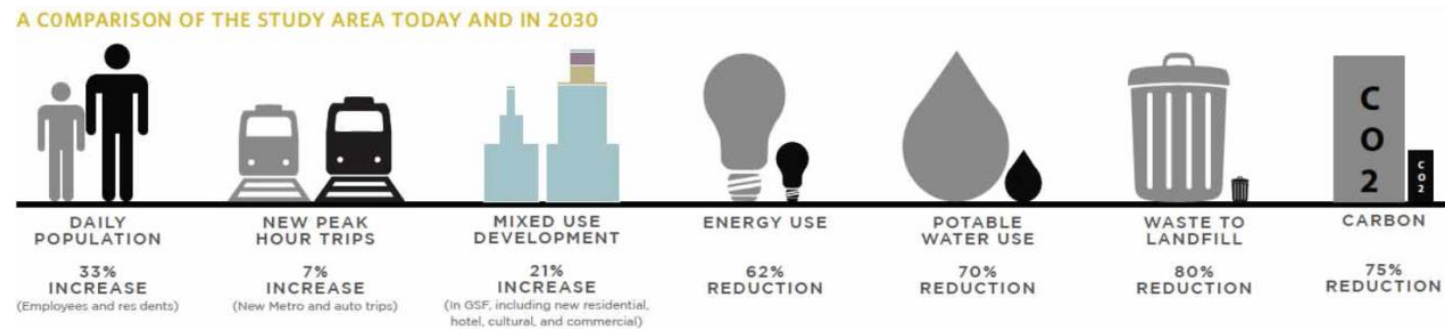

Figura 17. O cenário comparativo antes e depois da implantação do plano geral mostra como a integração entre estratégias ambientais e de sustentabilidade podem atingir os objetivos do plano para o bairro ecológico. Fonte: National Capital Planning Comission, 2013.

O caráter cívico da área será alavancado através da criação de uma variedade de espaços abertos de qualidade e ofertas culturais como museus e memoriais. Os espaços abertos contarão com a criação de parques e praças com acessibilidade universal, segurança e que convidem os pedestres à recreação, aumentando a qualidade dos ambientes existentes. As ruas e avenidas tirarão proveito dos eixos de perspectiva e vistas cênicas, criando pontos focais de grande interessa à paisagem local. A ideia é de criar ruas que sejam caminháveis, belas, verdes, seguras e vibrantes.

Para melhorar a circulação na área, as superquadras serão transformadas em quarteirões menores, mais apropriados à escala do pedestre, criando novas conexões na malha viária. Serão implantadas ciclovias, calçadas e ruas que liguem aos modais de transporte, como ônibus e metrô, já existentes, que terão suas malhas expandidas, como se pode observar na figura 19. A Avenida Maryland será transformada em um boulevard intermodal de transporte e será o elemento central do projeto. Também será incentivado o uso de veículos elétricos, aluguel de carros e bicicletas para que o uso do automóvel particular diminua com o tempo e aceitação dos usuários. 


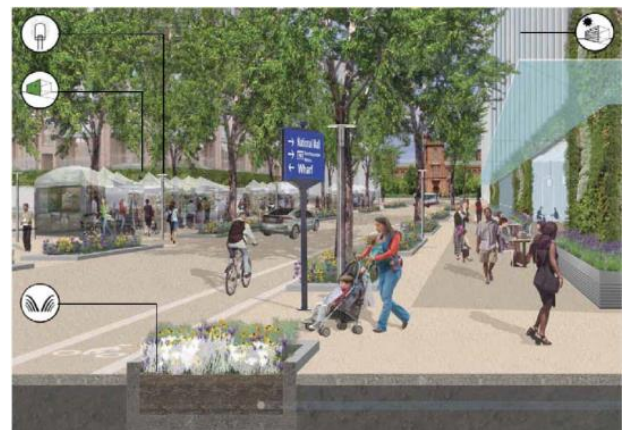

Figura 18. Perspectiva de corte da rua mostrando fachada ativa, infraestrutura verde e ciclovia. Fonte: National Capital Planning Comission, 2013.

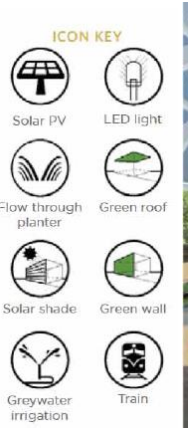

Figura 19. Perspectiva mostrando terminal intermodal previsto no projeto. Fonte: National Capital Planning Comission, 2013.

Os edifícios existentes serão reformados para que se tornem mais eficientes em questões de aproveitamento energético e energia renovável, principalmente de origem solar, será produzida na área e distribuída por toda ela. (figura 20). Toda água da chuva será capturada, limpa e reservada em cisternas para uso posterior em sanitários, sistemas mecânicos e irrigação, como se vê na imagem 21. Programas de reciclagem e compostagem serão implantados.

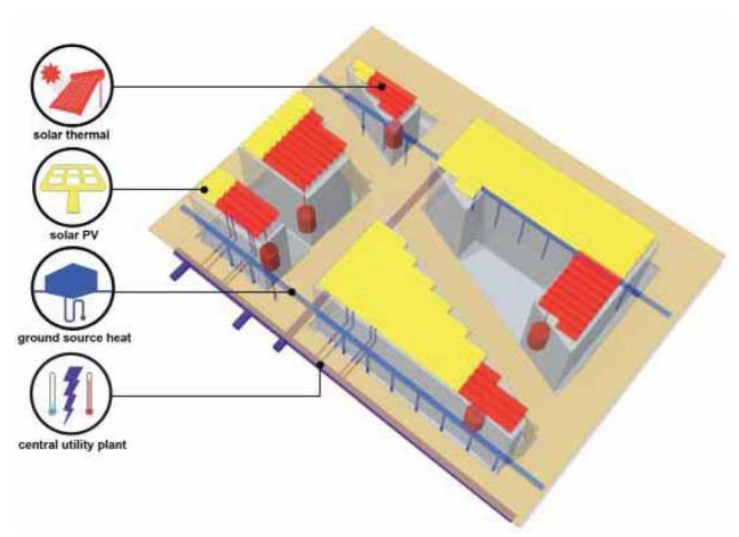

Figura 20. Plano de captação de energia solar na escala da quadra. Fonte: National Capital Planning Comission, 2013.

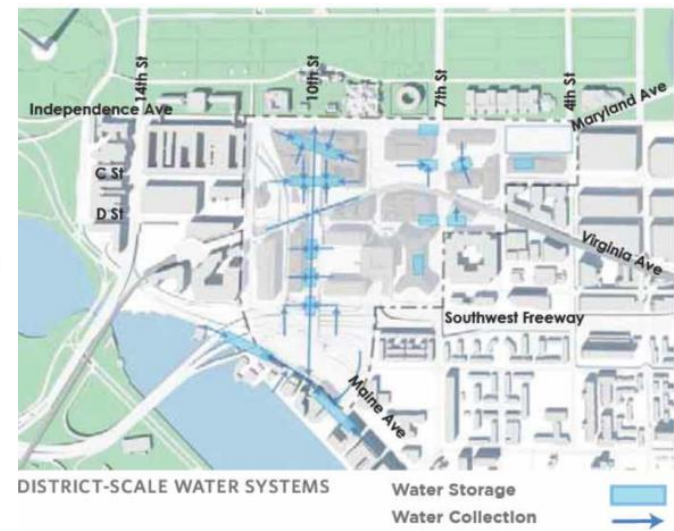

Figura 21. Plano de captação de águas pluviais. Fonte: National Capital Planning Comission, 2013.

O projeto também conta com diretrizes de infraestrutura verde, apresentadas na figura 22, que contarão com telhados verdes, parques, biovaletas e paredes verdes que ajudarão a reduzir o efeito da ilha de calor, criando conforto para os pedestres. O sistema também vai criar 
corredores ecológicos interligados ao Canal de Washington. As ruas serão projetadas para reter, filtrar e transportar as águas pluviais através de jardins de chuva (figura 23) e biovaletas e serão parte importante de todo o sistema de tratamento de águas. Nos tetos verdes será incentivada a criação de jardins comestíveis. Parques e praças contarão com vegetação nativa e terão a missão de criar espaços de socialização que colaborem com a reconexão do homem à natureza.

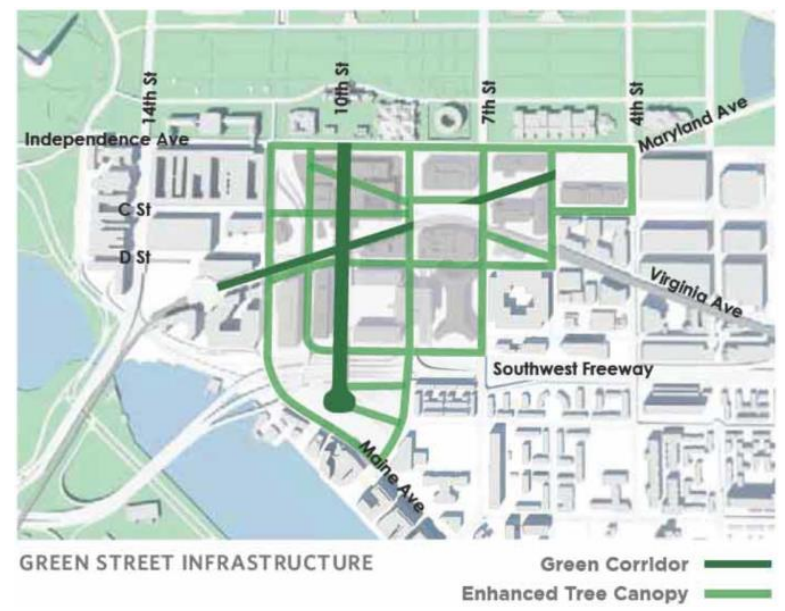

Figura 22. Plano de infraestrutura verde mostrando em verde escuro os corredores verdes ecológicos e em verde claro a melhoria da arborização urbana. Fonte: National Capital Planning Comission, 2013.

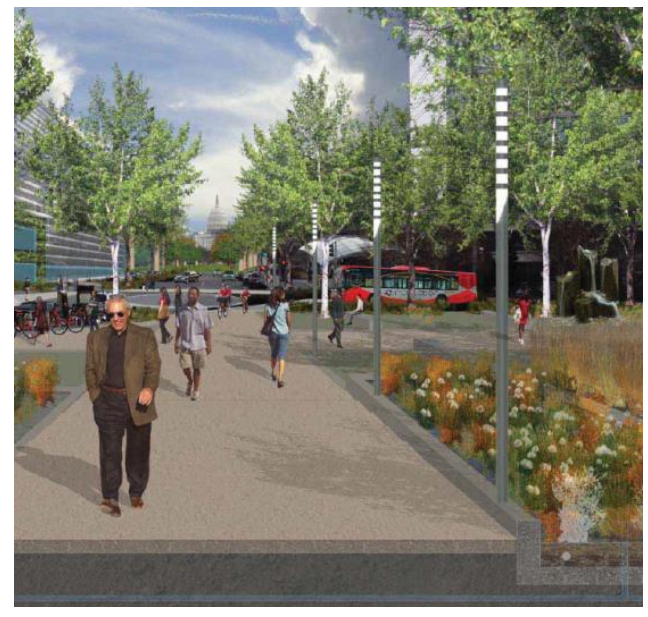

Figura 23. Jardins de chuva responsáveis pela captação, filtragem e escoamento das águas pluviais. Fonte: National Capital Planning Comission, 2013.

Trabalhando com a parceria público-privada e reuso dos edifícios mal aproveitados, o plano pretende melhorar a eficiência das operações federais e oferecer ao setor privado oportunidades de desenvolvimento, criando até o ano de 2030 um ecobairro sustentável e de alta eficiência que ofereça maior qualidade de vida a seus usuários.

Analisando a tabela 04, que marca em verde os princípios do urbanismo ecológico atendidos pelo projeto, vemos que apenas alguns não são evidenciados como o planejamento participativo, priorização do pedestre e governança verde. Os demais como aumento da densidade e diversidade de usos, transporte sustentável, corredores verdes e outros são 
considerados no projeto a agregam ao mesmo grande potencial para se tornar um bairro ecológico.

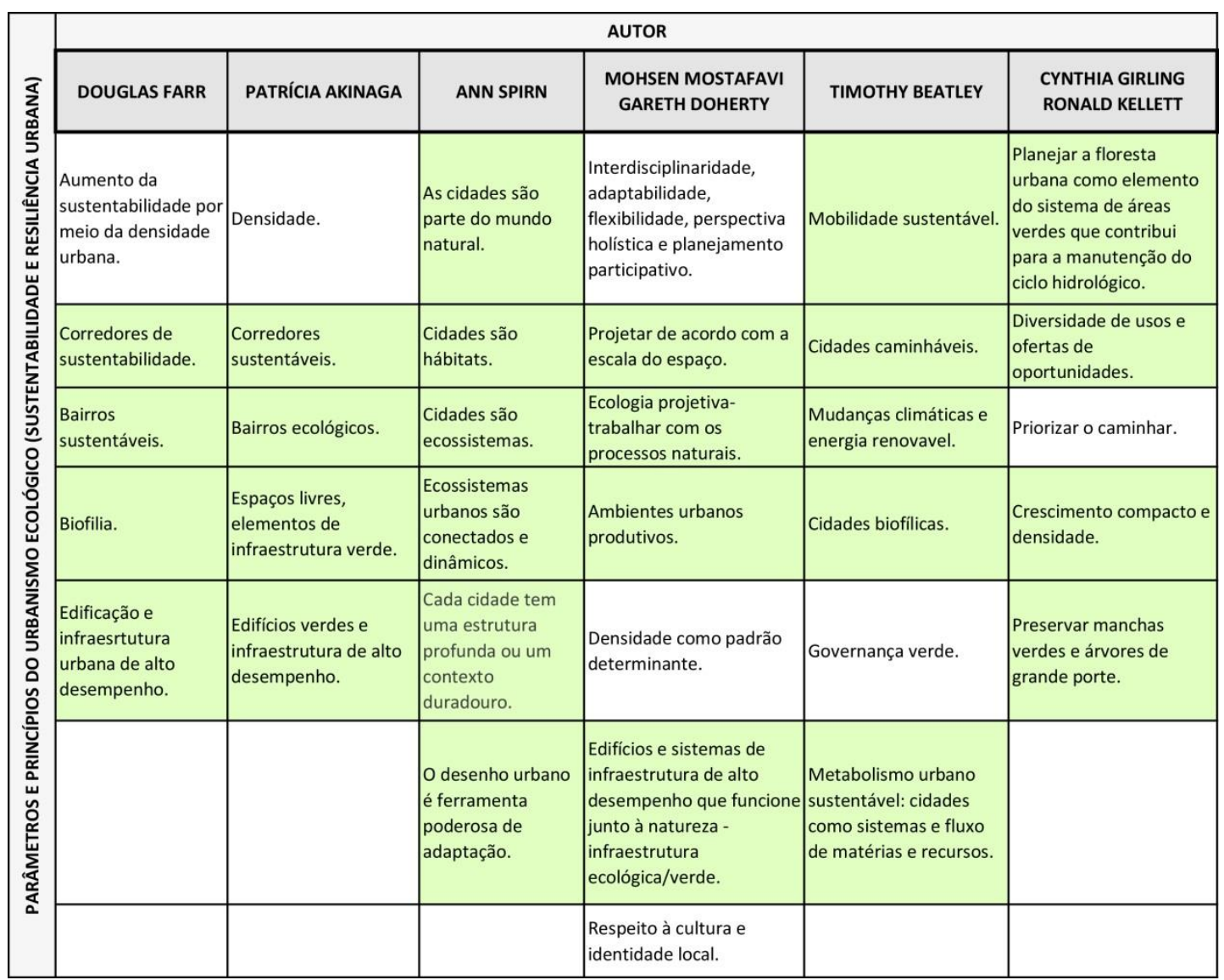

Tabela 04. Tabela dos princípios do urbanismo ecológico mostrando em verde os pontos atendidos no projeto do Southwest District.

\subsection{ECOVILAS}

Como colocado anteriormente, a distinção entre ecobairros e ecovilas é muito sutil e muitas vezes um pode ser chamado pelo nome do outro por uma mera questão de indefinição de classificação entre essas categorias. Para esse trabalho, que se apoia na literatura dsponível e leitura dos projetos construídos e em desenvolvimento, adotar-se-á o entendimento de que a ecovila abrange as práticas geridas pela própria comunidade em grupos de menor escala com menores pretensões urbanas que o ecobairro. Isso quer dizer que elas não vão atingir todos os 
objetivos e princípios urbanísticos colocados anteriormente como melhoria do sistema de transportes, uso misto com oferta de escolas, comércio, serviços e outros pontos de caráter mais ligado ao planejamento urbano. Com base nos modelos em funcionamento, percebe-se na ecovila um caráter muito mais vernacular, naturalista, de comunhão com a natureza e a sociedade.

\subsubsection{Definição de Ecovila}

De acordo com Soares e Langner (2014), "a ecovila é uma modalidade de comunidade intencional classificada entre as melhores práticas de desenvolvimento sustentável do mundo." D'Avila (2007), coloca que as ecovilas abrangem questões relativas à auto-gestão e economia coletiva. São, de forma geral, comunidades formadas intencionalmente por grupos organizados em busca de uma proposta comum que abrange questões relativas ao respeito à natureza e aos recursos naturais, o baixo impacto ambiental, a vida em comunidade, a espiritualidade, a sustentabilidade e a qualidade de vida. Para Robert Gilman (1991) ecovilas, ou ecoaldeias, são:

"assentamentos em escala humana, completos, em que as atividades humanas são inofensivamente integradas ao mundo natural de forma que apoiem o desenvolvimento humano saudável e que possa prosseguir com êxito para o futuro indefinitivamente". (GILMAN, 1991, p. 10).

Segundo Braga e Gonçalves:

"O conceito de ecovilas foi definido em 1995, durante um encontro de representantes de diferentes grupos do gênero em Findhorn, ao norte de Edinburgo, capital da Escócia. Passaram a levar esse título apenas os assentamentos que se sustentam no âmbto social, ecológico, econômico e visão de mundo." (BRAGA; GONÇALVES, 201 1).

A definição divulgada pela Rede Global de Ecovilas (traduzido do inglês Global Ecovillage Network - GEN) é:

"Uma ecovila é uma comunidade intencional ou tradicional que é conscientemente projetada através de 
processos participativos locais para holisticamente integrar as dimensões ecológica, econômica, social e cultural, a fim de regenerar seus ambientes sociais e naturais. Ecovilas abraçam o conceito de simplicidade, celebrando e recriando estilos de vida de baixo impacto que expandem um senso de cuidado, responsabilidade e bem-estar." (GEN, 2017, tradução nossa).

A organização GEN oferece cursos e consultorias em todo o mundo, propondo suporte às ecovilas existentes e aos cidadãos que se interessam em desenvolver o modelo. Com especialistas em diversas áreas do conhecimento e grande experiência prática no planejamento e gerenciamento de vilas ecológicas, como Robert Alfred, membro do Conselho Consultor da Fundação Findhorn", promove cursos e soluções nas áreas de projeto integrado para ecovilas e escolas verdes, processo participativo, governança e tomada de decisão, estratégias para aprimoramento de economias e comunidades locais, desenvolvimento humano sustentável e construção de comunidades sustentáveis, alagados construídos para purificação de águas, administração da fertilidade do solo, permacultura e produção de alimentos orgânicos e arquitetura com a terra.

O tamanho de uma vila ecológica pode variar, mas geralmente são projetos de pequena escala, que variam de apenas um bando de casas até comunidades maiores que quase conformam bairros, onde muitas das hoje existentes são evoluções de experiências comunitárias, como citado por Sizemore (2004), que aponta as experiências de moradia compartilhada de Ithaca em 1960 (Nova York, EUA), as comunidades hippies como The Farm (Tennessee, EUA), assentamentos antroposóficos como a Comunidade Camphill (Vallersund, Noruega) e assentamentos de permacultura, como Crystal Waters (Brisbane, Austrália). Outras comunidades com foco espiritual também originaram ecovilas por todo o mundo.

\footnotetext{
${ }^{8}$ Fundada em 1972 na baía de Findhorn, Escócia, é tida como a primeira ecovila do mundo.
} 
Muitos desses projetos foram implantados inicialmente em áreas rurais, devido a seu caráter experimental, mas nos últimos anos, muitos têm aparecido no contexto urbano, principalmente nas franjas da urbanização ou remodelando cidades históricas. Nos Estados Unidos e países da África, muitas ecoaldeias foram criadas com o intuito de combater a pobreza, violência infantil, desemprego e outros problemas sociais. (SIZEMORE, 2004)

Algumas das práticas mais comuns dessas comunidades incluem a produção de alimento, a utilização de energia renovável, como energia solar, construção com técnicas biossustentáveis, incluindo soluções alternativas para o sanemaento, a permacultura, a economia solidária e a habitação compartilhada. (SOARES; LANGNER, 2014; D'AVILA, 2007). São alternativas que ajudam a produzir recursos para as necessidades básicas dos moradores. (SIZEMORE, 2004).

As relações sociais também são um ponto fundamental quando se fala de vilas ecológicas. A proximidade entre os habitantes e a filosofia comum que levou à criação do projeto estreita os vínculos entre os moradores e contribui para aumentar o sentimento de comunidade e auto-ajuda entre os mesmos. (D'AVILA, 2007).

Criar uma ecovila é um processo e não algo com começo, meio e fim (SIZEMORE, 2004) e por isso o planejamento das ações em todas as etapas desse processo de preparação são importantes para garantir o sucesso e a longevidade da comunidades. (SOARES; LANGNER, 2014). Esses processos são baseados nas características do lugar e entendidos e administrados de forma holística e integrada.

A Rede Global de Ecovilas coloca que, através da divulgação das boas práticas, das soluções inovadoras e honrando o conhecimento historicamente adquirido das comunidades tradicionais, pode-se criar um conjunto de conceitos e conhecimentos para um viver sustentável em escala global, já que as ecovilas representam estilos de vida que podem prosseguir com sucesso por um futuro indefinido, tendo sido colocadas, 
em 1998, na lista da ONU de 100 Melhores Práticas como excelente modelo de vida sustentável. (GEN, 2017).

\subsubsection{Ecovila Findhorn Foundation - Forres (Escócia)}

Fundada em 1972 por Peter e Eileen Caddy e Dorothy Maclean, na baía de Findhorn, Escócia, é tida como a primeira ecovila do mundo e autodefinida como comunidade espiritual, ecovila e centro internacional de ensino holístico, com profunda ligação aos elementos naturais que visa o desdobramento da consciência humana para criar um futuro mais positivo e sustentável. Apresenta o conceito de educaçao vivenciada, através da experiência da vida comunitária e suas atividades, também possuindo uma escola infantil com método baseado em Rudolf Steiner/Waldorf e também conta, desde 2011, com educação especiaizada que oferece cursos de inglês, vida em comunidade e mestrado em projetos de comunidades sustentáveis. (SOARES; LANGNER, 2014, RIDDELL, 1990, FINDHORN FOUNDATION, 2017).

A comunidade não tem um projeto urbanístico, tendo surgido espontaneamente, então sua forma é resultado natural de seu tipo de ocupação inicial e expansão, como mostra a figura 24. Ela nasceu e cresceu do sucesso dos fundadores em plantar vegetais, quando desempregados. Abriga cerca de 400 moradores, recebendo em torno de 14 mil pessoas por ano que são atraídas pelos cursos de vivência em comunidade e pelas práticas espirituais. Abrange hoje os espaços conhecidos como o Parque (espaço original onde os fundadores se instalaram), a colina Cluny e Findhorn, todos adquiridos através de angariação de fundos coletivos. (GREEN BUILDING BLOG, 2013). 


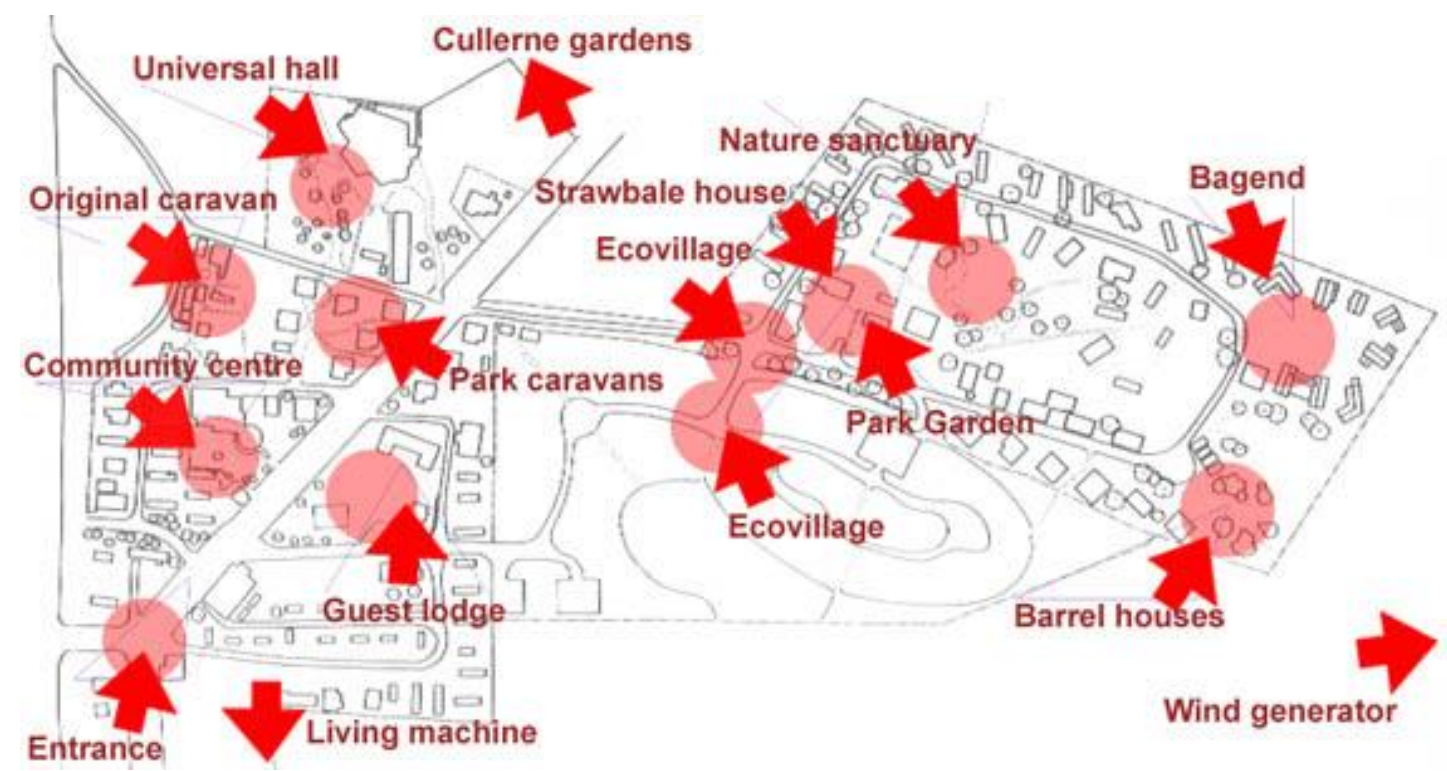

Figura 24. Mapa de localização de espaços e atividades em Findhorn. Fonte: Ecohouse agent, 2017.

O Parque é o local onde a fundação começou, através dos jardins de Eileen Caddy em 1962 e também o principal local de ocupação da fundação. Possui casas ecológicas fixas e móveis, como traillers, que abrigam 300 moradores e 100 visitantes. É nele que estão cerca de 90 estruturas ecológicas ligadas a infraestrutura da vila, como a Máquina Viva (figura 25), estufa responsável pelo tratamento biológico do esgoto e da água utilizada na aldeia. No parque tembém estão localizadas as 4 turbinas eólicas (figura 26), capazes de produzir 140\% da energia necessária para iluminação local, diversos jardins e hortas de vegetais orgânicos que contribuem para manter a conexão entre homem e natureza (figura 27), além de comércios e iniciativas ligados à educação, artes e saúde. (SOARES; LANGNER, 2014, FINDHORN FOUNDATION, 2017).

Outros elementos contribuem para a sustentabilidade e marca de vila ecológica do lugar. Uma caldeira computadorizada é responsável pelo aquecimento da água. Utilizando restos de lenha, distribui a água quente pelas residências e demais edifícios, diminuindo as emissões de carbono em cerca de 80 toneladas por ano. Utiliza aquecimento solar (figura 28) para contribuir com a calefação da água e das residências, 
que tem grande utilização de vidro para facilitar a entrada de luz solar (BRAGA; GONÇALVES, 2011). Tecnologia de ponta é utilizada nas casas ecológicas, que uilizam elementos de infraestrutura verde, como telhado verde. A comunidade recicla todo o lixo produzido no local e trabalha com compostagem para lixo orgânico, reduzindo assim as taxas de produção de resíduos. Não possui grades, é uma comunidade aberta e tem um sistema de compartilhamento de carros com veículos elétricos com zero emissão de carbono. (FINDHORN FOUNDATION, 2017).

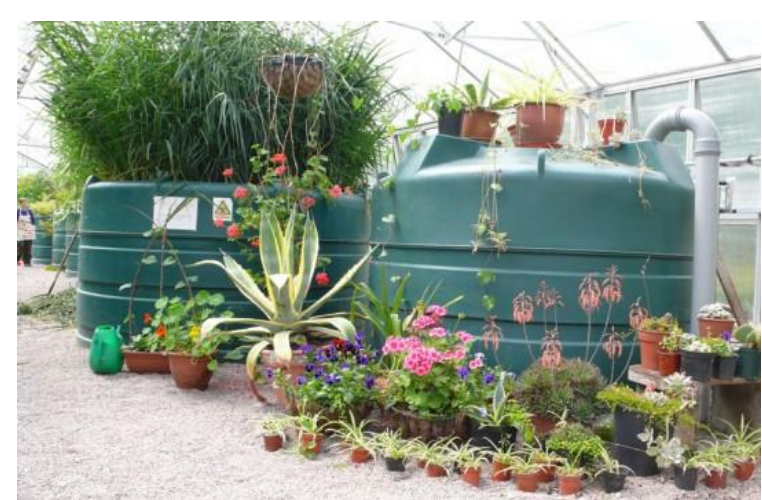

Figura 25. Máquina viva, estrutura responsável pelo biotratamento da água e esgoto local. Fonte: Same same, 2011.

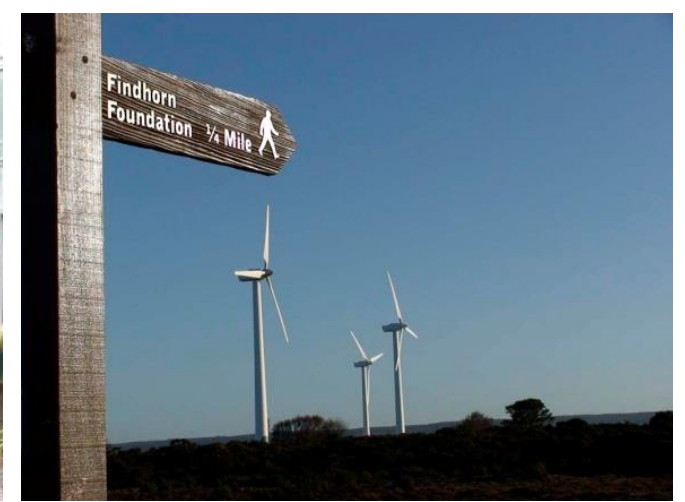

Figura 26. Hélices de energia eólica. Fonte: Findhorn Foundation, 2015.

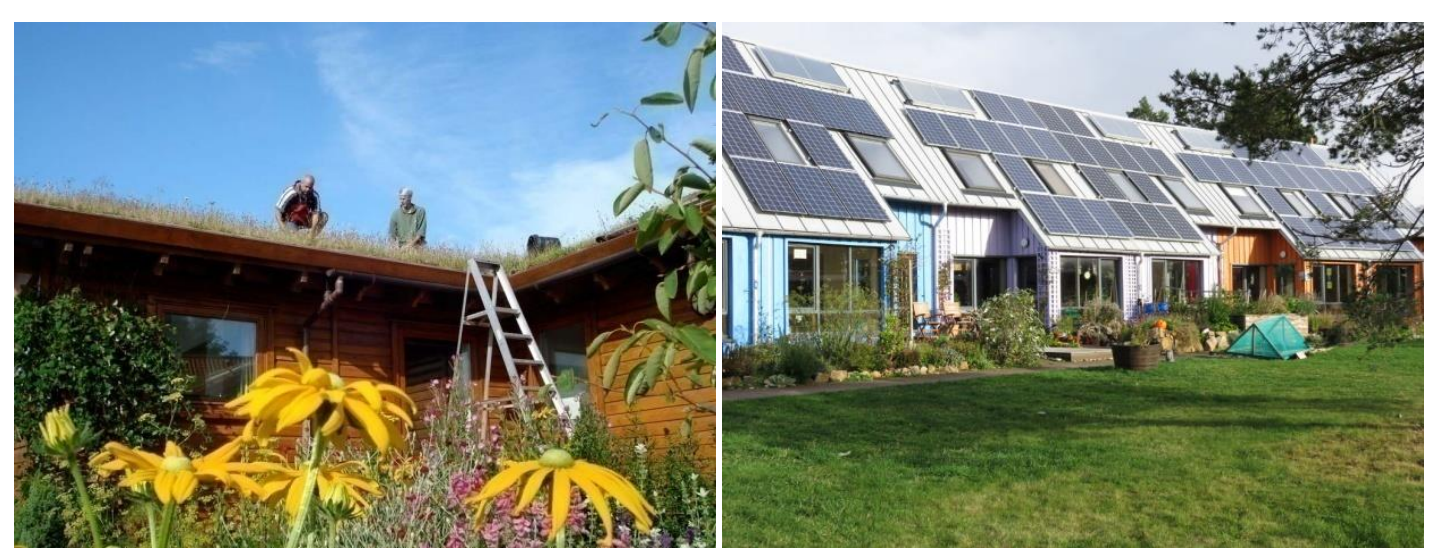

Figura 27. Jardins comunitários. Fonte: Figura 28. Casas com placas solares no Findhorn Foundation, 2017. telhado. Fonte: Findhorn Foundation, 2015.

A ênfasee na criação coletiva levou à busca de soluções mais ecológicas para a construção das residências, que acarretou diversas tentativas e opções de moradias construídas, algumas com madeira de barris de whiskey, como mostra a figura 29, até que chegaram ao 
consenso da madeira com tratamento térmico, figura 30. Com a evolução das técnicas, foi criado o Campo dos Sonhos, área com casas projetadas por arquitetos, confortáveis, ecológicas e coloridas, inseridas em uma área extremamente vegetada, muitas com sua própria produção de hortaliças. Na comunidade também existem residências coletivas. (GREN BUILDING BLOG, 2013).

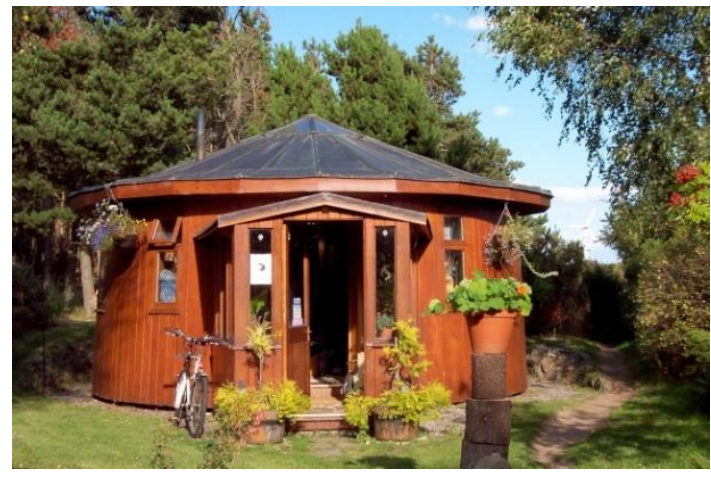

Figura 29. Casa construída com madeira de barris de whiskey. Fonte: Findhorn Foundation, 2017.

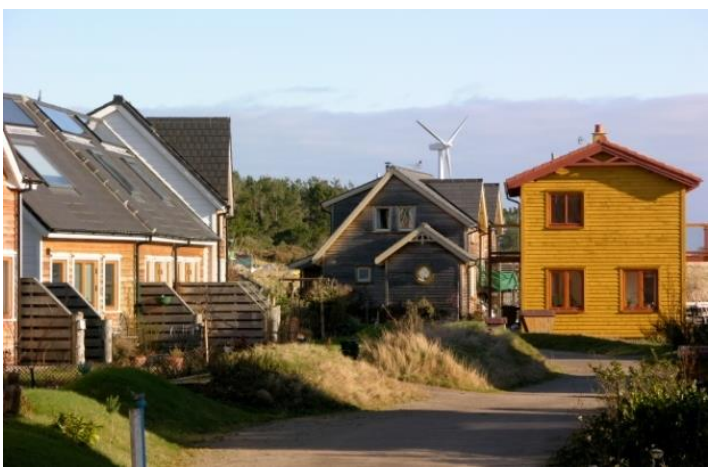

Figura 30. Casa construída com madeira e tratamento térmico. Fonte: Findhorn Foundation, 2017.

Suas ruas são estreitas, sem calçadas e os carros são permitidos. Não há um tipo específico de construção nem restrições para as mesmas, então nota-se uma grande diferença de estilos e também de padrões nas mesmas, que vão desde casas projetadas e bem acabadas, até trailers e cabanas, como mostram as figuras 31 e 32 a seguir.

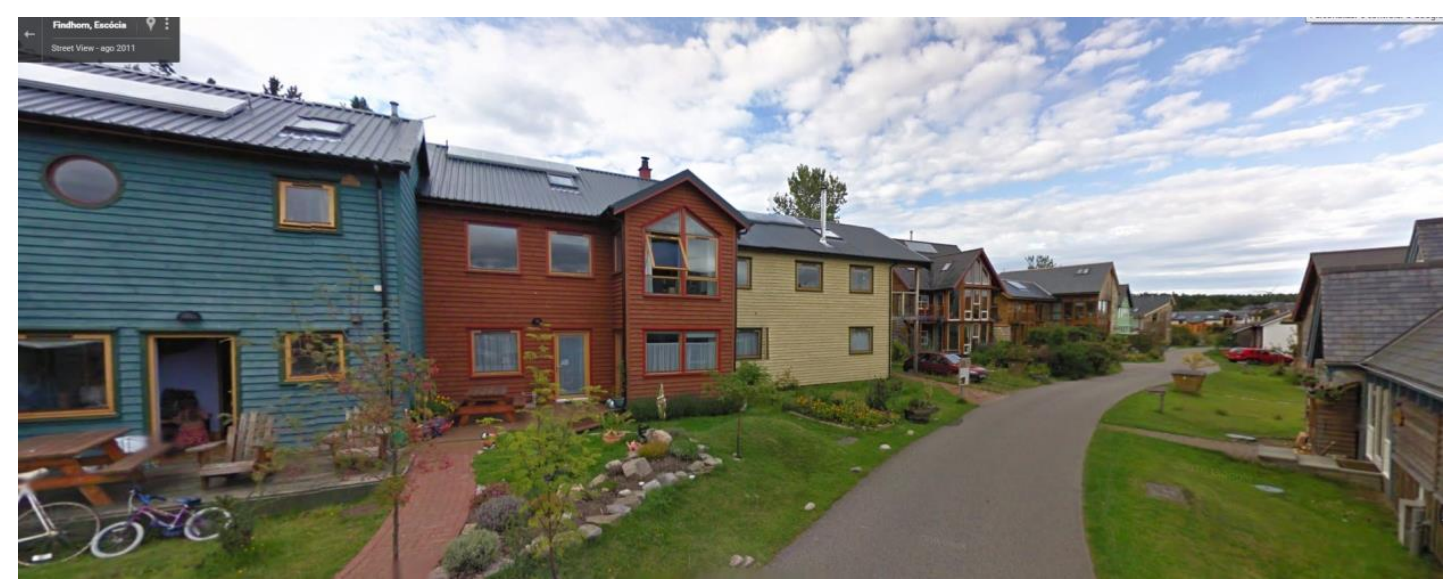

Figura 31. Panorama de uma rua em Findhorn mostrando o estilo de suas residências. Fonte: Google street view, 2017. 
Possui administração própria, um comitê gestor eleito pelos moradores e cada morador contribui com a manutenção e administração do espaço, dos jardins e das construções. As decisões são tomadas coletivamente, com a participação dos moradores. Possui uma moeda própria e quem contribui com trabalho na vila é recompensado com uma quantia fixa, que era de 200 libras em 2001(BRAGA; GONÇALVES, 2011), pagos na moeda local chamada de Eko e com moradia. (SOARES; LANGNER, 2014, RIDDELL, 1990, FINDHORN FOUNDATION, 2017).

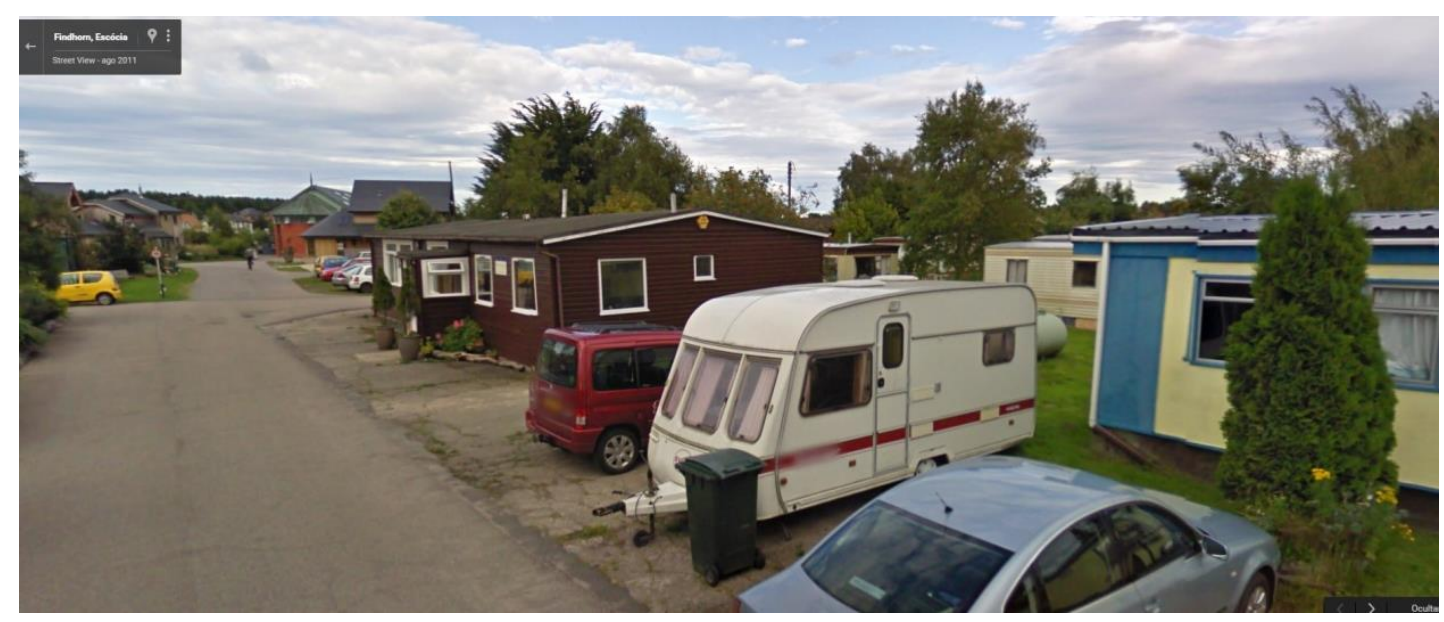

Figura 32. Panorama de uma rua em Findhorn mostrando casas no estilo cabana e mototraillers. Fonte: Google street view, 2017.

Os valores sustentáveis e ecológicos de Findhorn estão expressos através das casas ecológicas, do usos de materiais locais, na beleza da arquitetura e dos jardins, na tecnologia aplicada ao tratamento de esgoto e águas através da Máquina Viva, da geração de eletricidade através das turbinas eólicas e da filosofia de buscar alternativas para um estilo de vida mais saudável, causando o mínimo impacto ambiental. Também são expressos através das iniciativas sociais, econômicas e educacionais da comunidade. Sua pegada ecológica representa metade da média do Reino Unido, sendo que a fundação recebeu da ONU o título de melhor prática de assentamento humano do mundo.

Tais valores ficam claros na tabela 05 que mostra, em verde, os princípios do urbanismo ecológico atendidos pela vila de Findhorn. Fica 
evidente, com tal análise, que as questões de planejamento urbanístico são ausentes no projeto, que fica isolado da cidade, sem se preocupar com questões relativas à mobilidade e densidade. Como boas práticas que ficam desse modelo temos o respeito aos elementos naturais, o incentivo à agricultura urbana e aos jardins coletivos, o uso de energia limpa e renovável, o sistema natural de tratamento de água, a governança verde e a participação coletiva nas decisões comunitárias.

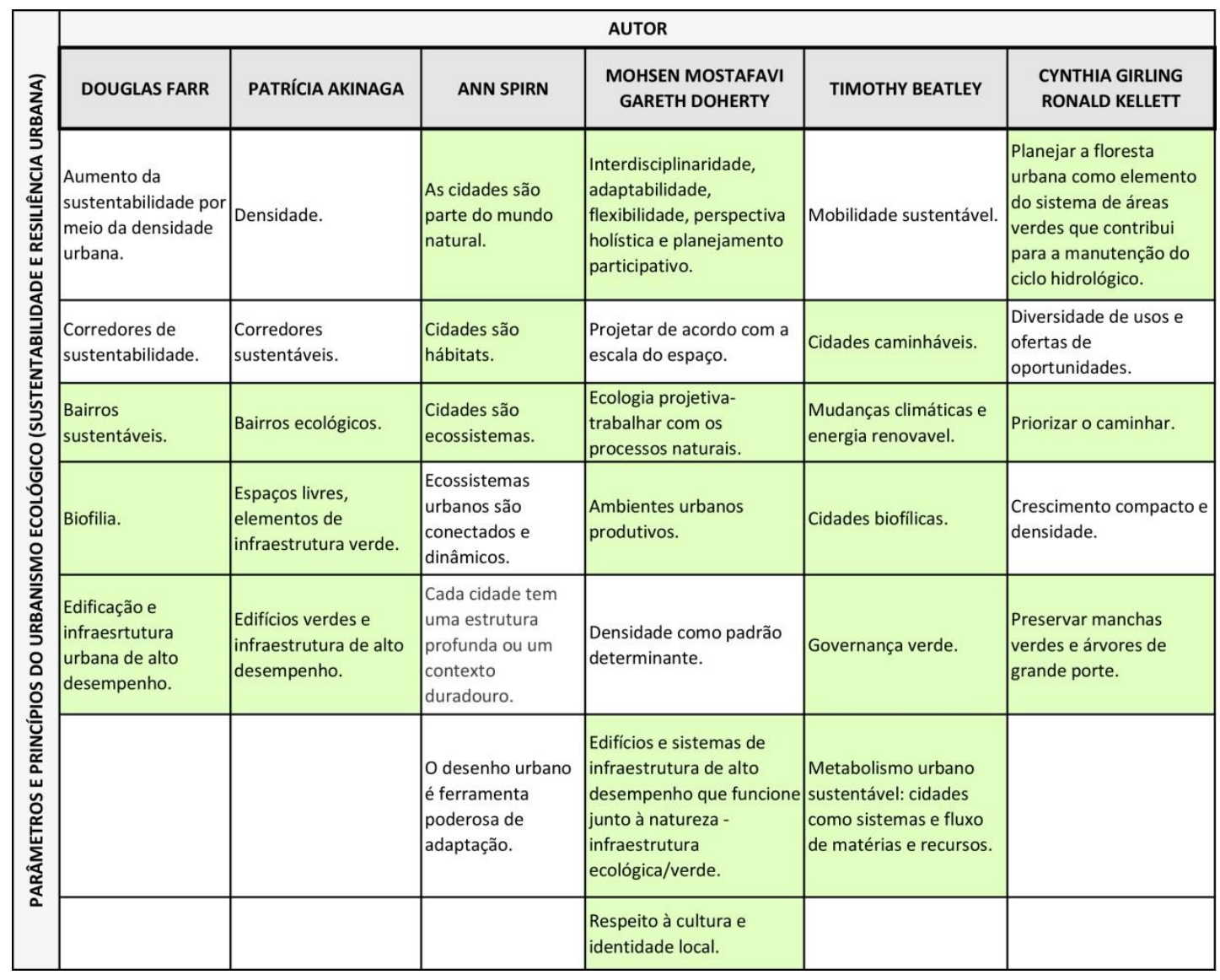

Tabela 05. Tabela dos princípios do urbanismo ecológico mostrando em verde os pontos atendidos no projeto de Findhorn.

\subsubsection{Ecovila Village Homes - EUA}

Village Homes, uma vila de aproximadamente 70 mil m2 nas redondezas da cidade de Davis, na Califórnia, tem sido amplamente considerada pelos estudiosos de comunidades ecológicas como um 
protótipo de ecovila. O projeto foi desenvolvido por Michael e Judy Cobert na década de 1970, com base no plano de Radburn, a primeira cidade jardim da América e concluído no ano de 1982. (GIRLING; KELLET, 2005, SOARES; LANGNER, 2014). Com o lema de "Viver em Paz", a ideia era criar uma comunidade modelo com práticas sustentáveis e produtivas. (ANDRADE, 2003). As imagens do plano geral de projeto (figura 33) e foto aérea de google dos dias atuais (figura 34), podem ser vistas abaixo.

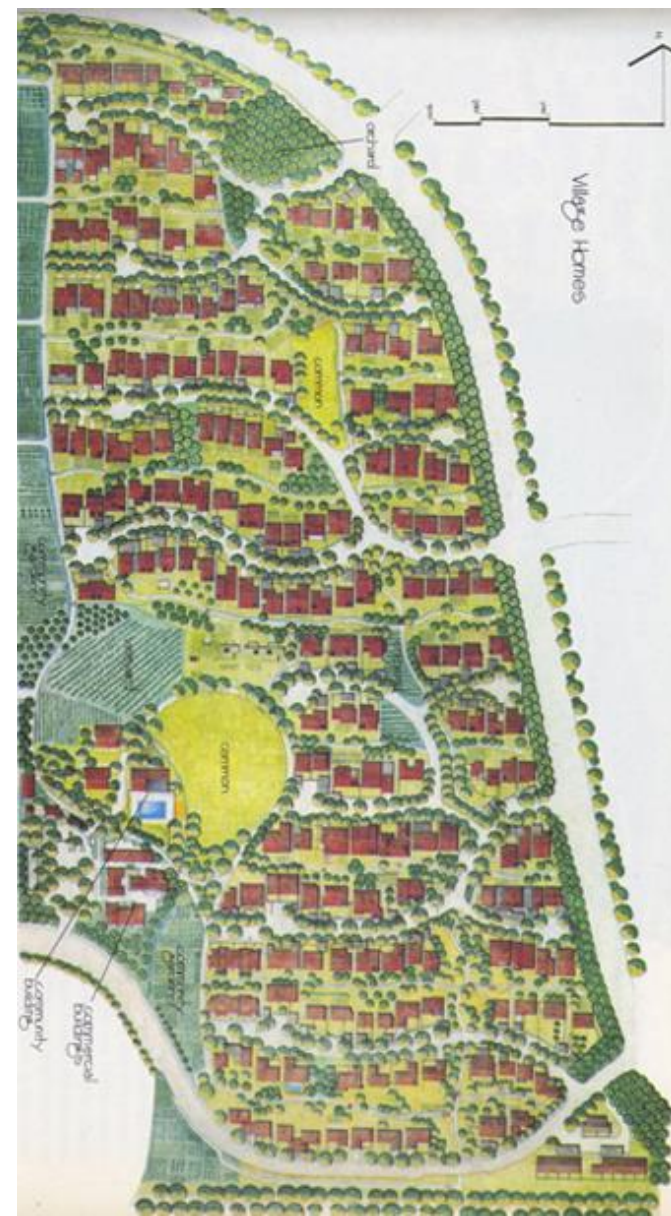

Figura 33. Plano geral do projeto. Fonte: MIT, Urban nature and city design, 2007.

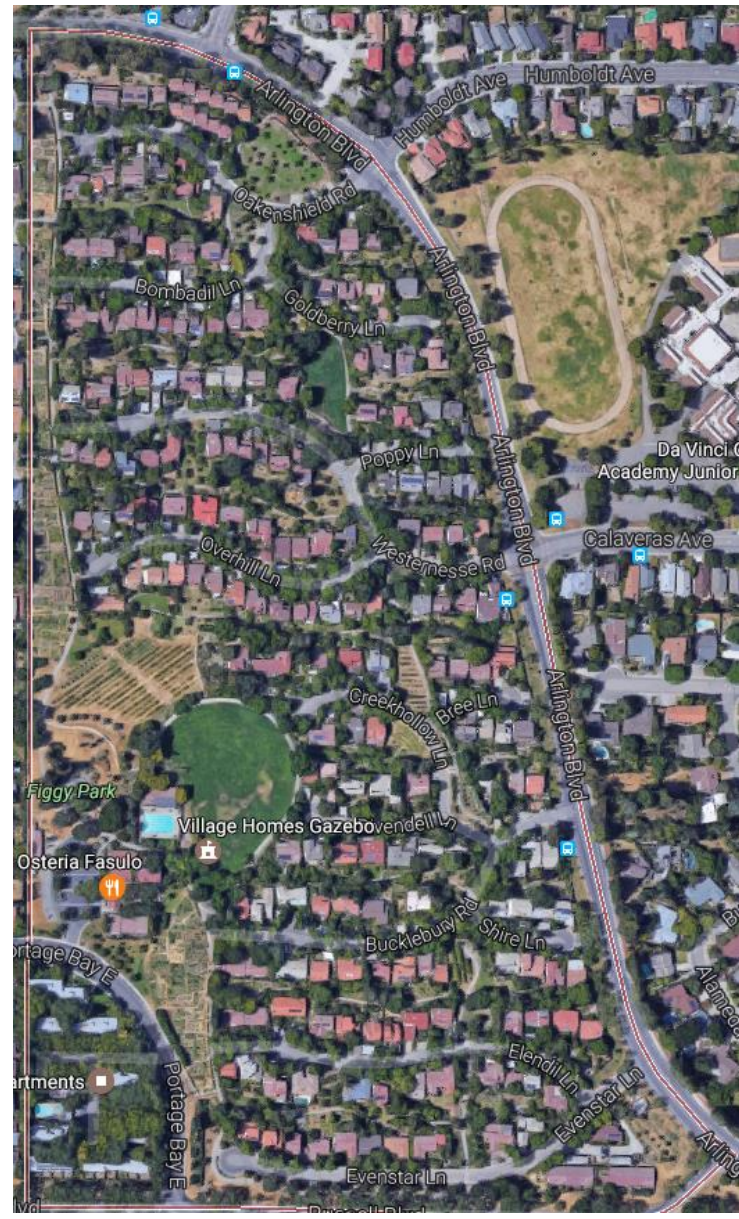

Figura 34. Imagem aérea do Google. Fonte: Google, 2017.

O projeto, de pequena escala, apresenta uma malha verde com conexões de pedestres e ciclistas que se sobrepõe a malha viária, sendo dela distinta, criando uma vasta rede de circulação e fluxo de matéria que se extende através de suas ligações com o entorno, como mostra a figura 35. Apresenta inovações sociais, econômicas e ecológicas, como a diretriz 
de priorização do pedestre, sistema de drenagem natural, jardins produtivos comunitários e utilização de energia solar. (GIRLING; KELLETT, 2005).

Para a circulação foram utilizados princípios bioclimáticos. As ruas estreitas, que forçam os automóveis a diminuirem sua velocidade, tem orientação leste-oeste e, juntamente à arborização das calçadas, contribuem para diminuir a temperatura e propiciar espaços de maior qualidade ao pedestre. Essa rede de passeios e ciclovias entremeadas às áreas verdes, como vemos na figura 36 , interligam todas as áreas da vila e fazem com que a distância máxima a caminhar seja de 5 minutos, com a segurança de não precisar atravessar as ruas. (SOARES; LANGNER, 2014, ANDRADE, 2003, GIRLING; KELLET, 2005).

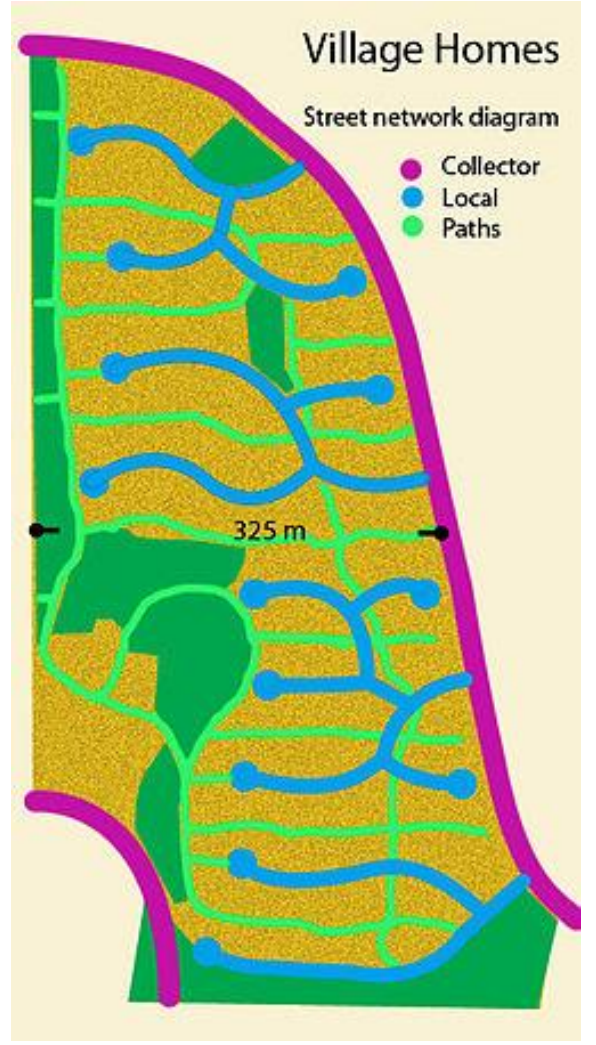

Figura 35 à esquerda. Esquema mostrando em verde claro, as ligações de pedestres e ciclovias em meio às áreas verdes e, em azul, as vias locais. Fonte: Wikipédia, 2017.

Figura 36 abaixo. Imagem do Google mostrando o momento em que uma via de pedestres encontra a rua local, bem como a arborização das vias locais. Fonte: Google street view, 2017.

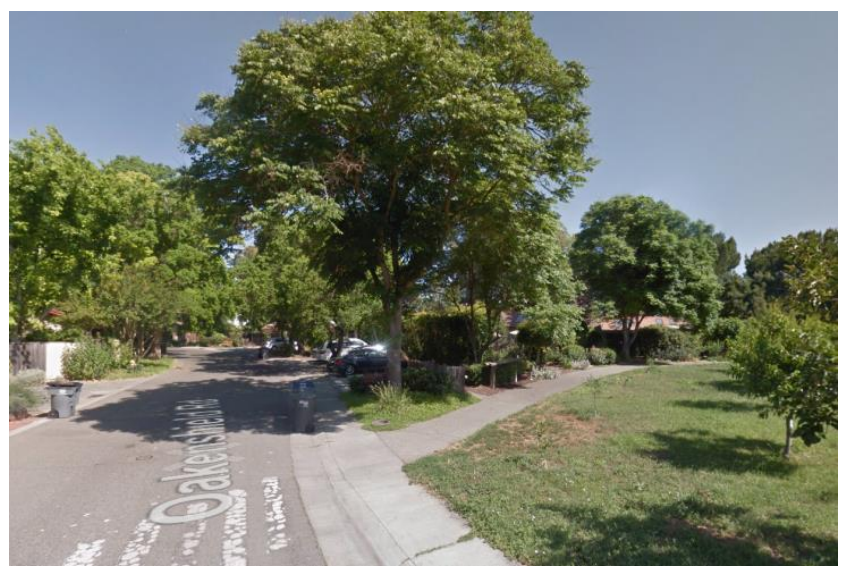

Para melhorar sua eficiência energética, as residências foram colocadas no sentido norte-sul, facilitando a ventilação cruzada e evitando o sol quente do sudoeste, eliminando a necessidade do uso de 
condicionamento mecânico. Todas as casas possuem aquecimento via placas solares, como é possível observar na imagem 32, que atendem $100 \%$ de suas necessidades no verão e 50\% no inverno. (SOARES; LANGNER, 2014).

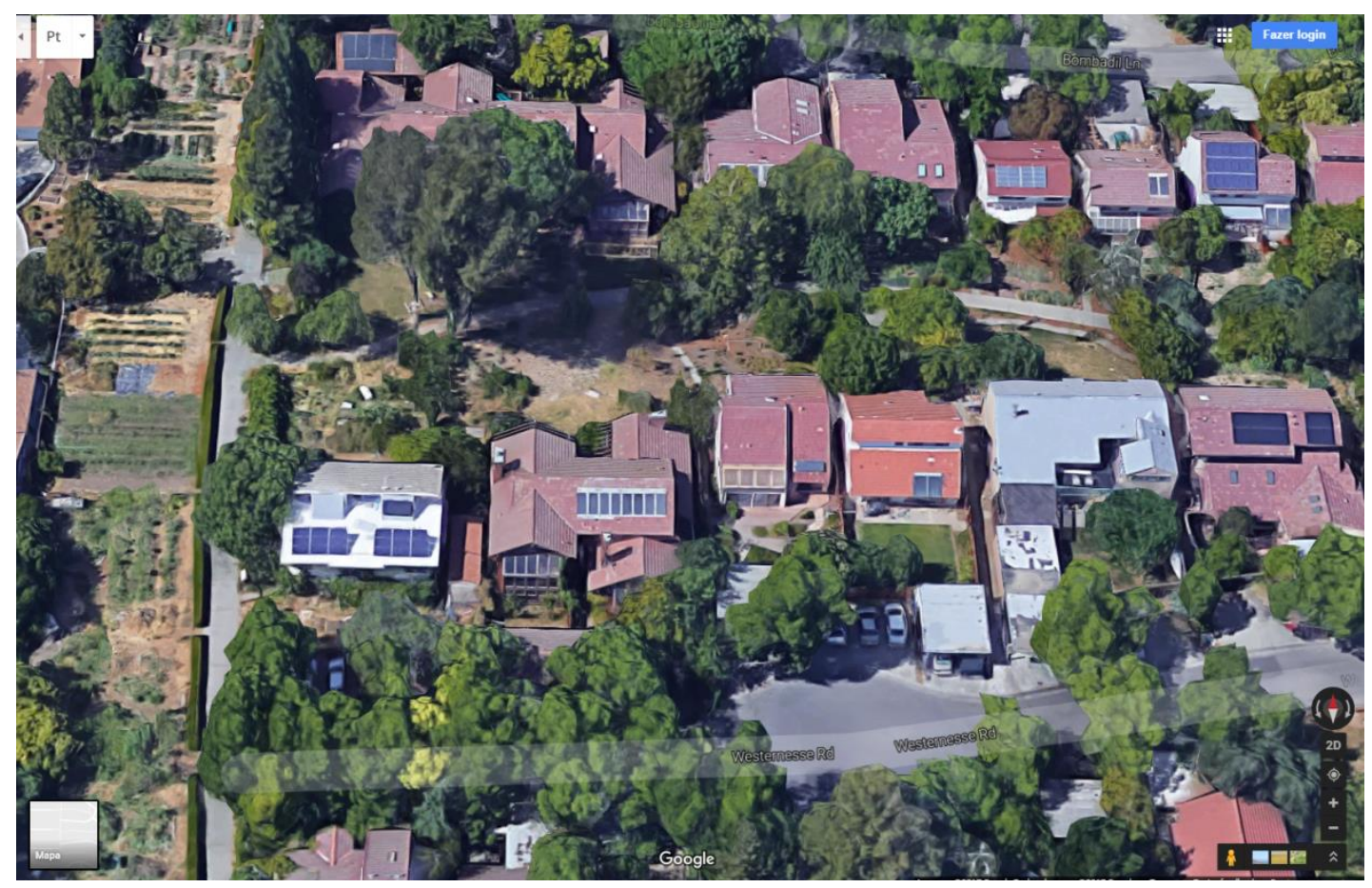

Figura 37. À esquerda cinturão voltado à plantação de frutas e hortaliças. Entre as casas pode-se ver área verde comum e passeio de pedestres e ciclcistas. Sobre os telhados das casas vê-se as placas de captação de energia solar. Fonte: Google, 2017.

Aproximadamente um terço da área é destinada aos espaços públicos, que são a espinha dorsal do projeto, visando a integração dos moradores e que foram projetados em hierarquia. Na escala menor, áreas comuns integram conjuntos de cerca de 8 casas (figura 37). Esses espaços são interligados aos espaços maiores através de caminhos verdes, com estrutura de drenagem natural, exclusivos de pedestres e bicicletas. $\mathrm{Na}$ escala macro os espaços comuns são compostos de praças, áreas de produção de alimentos e jardins comunitários. (SOARES; LANGNER, 2014, ANDRADE, 2003, GIRLING; KELLET, 2005). Isso mostra que os jardins foram pensados não só como elemento de embelezamento mas também como infraestrutura verde, como vê-se nas figuras 38 e 39. 


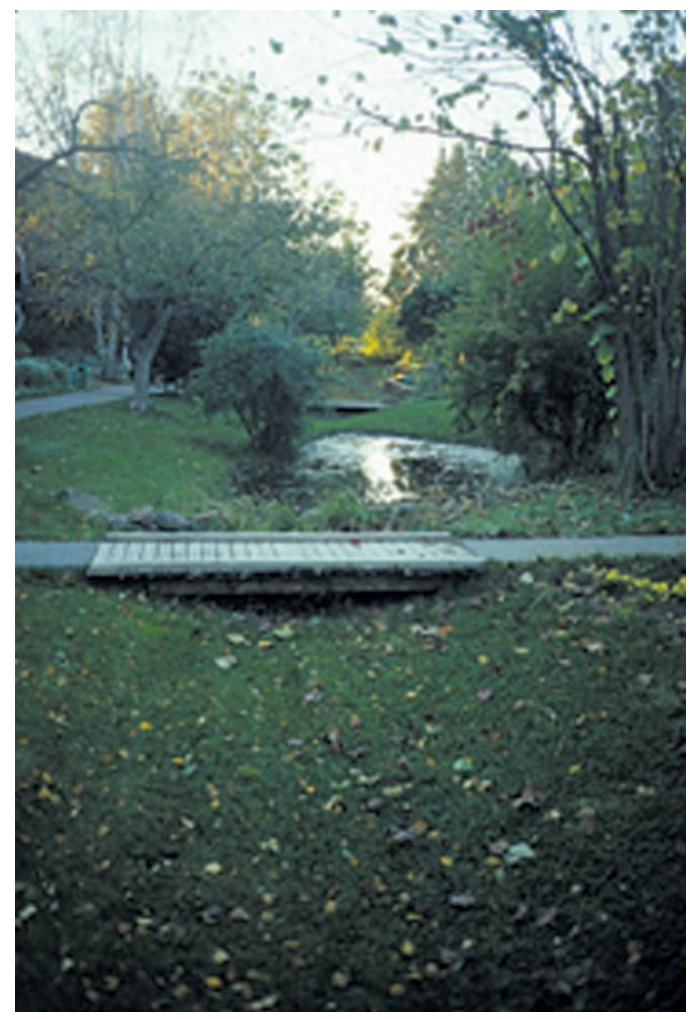

Figura 38. Área verde com biovaleta e bacia de detenção. Fonte: Pacific Horticulture, 2006.

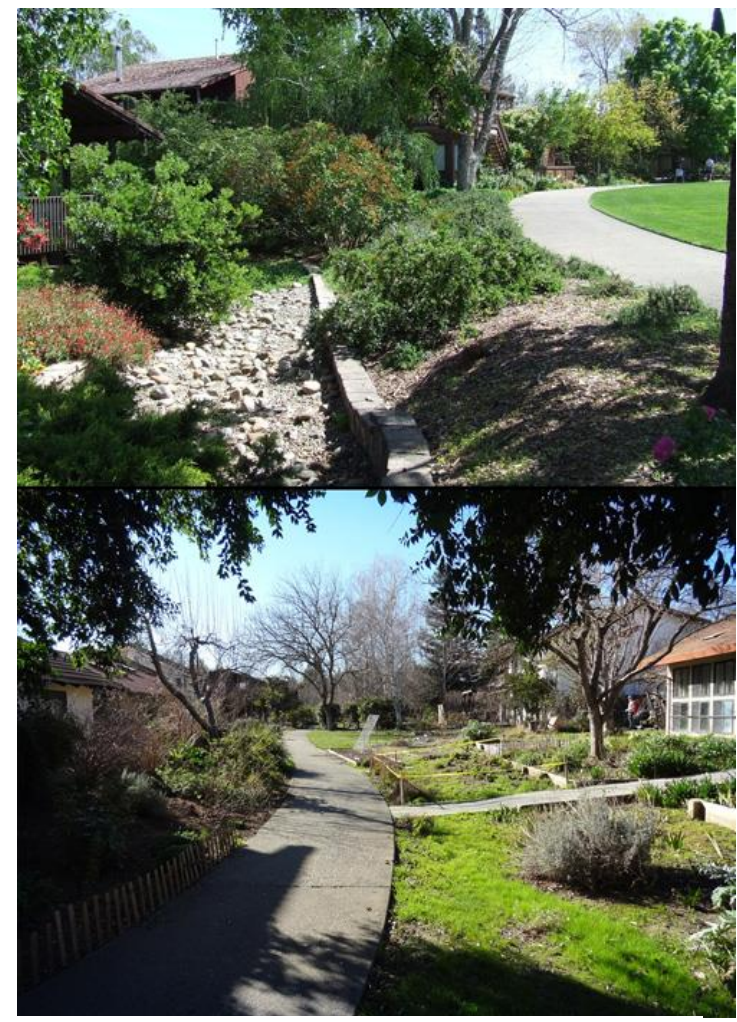

Figura 39. Biovaleta de pedra e valeta gramada para drenagem de águas pluviais. Fonte: Pacific Horticulture, 2006.

Todo o sistema de drenagem de águas pluviais foi projetado de forma natural onde uma rede de biovaletas coleta o excedente de água das chuvas carregando-os para uma lagoa de detenção que permite que a água seja absonvida vagarosamente pelo solo. Esse sistema é interligado ao sistema de córregos existentes, como mostra a figura 40. (ANDRADE, 2003). O sistema se mostra, até os dias de hoje, eficiente e de baixo custo. (GIRLING; KELLET, 2005).

Outras áreas de estar e lazer como playgrounds, uma escola infantil, um restaurante e uma pequena área comercial estão presentes na comunidade. (ANDRADE, 2003, GIRLING; KELLET, 2005). Por não contarem com atividades que suprem as necessidades diárias de seus habitantes, estes tem que pegar a bicicleta ou carro para ter acesso a um 
supermercado ou serviços básicos. Esse constitui um ponto fraco do projeto.

A comunidade possui um sistema de cooperativa onde o lucro com venda dos alimentos produzidos no local (figura 41) é utilizado para a manutenção da comunidade. (ANDRADE, 2003).

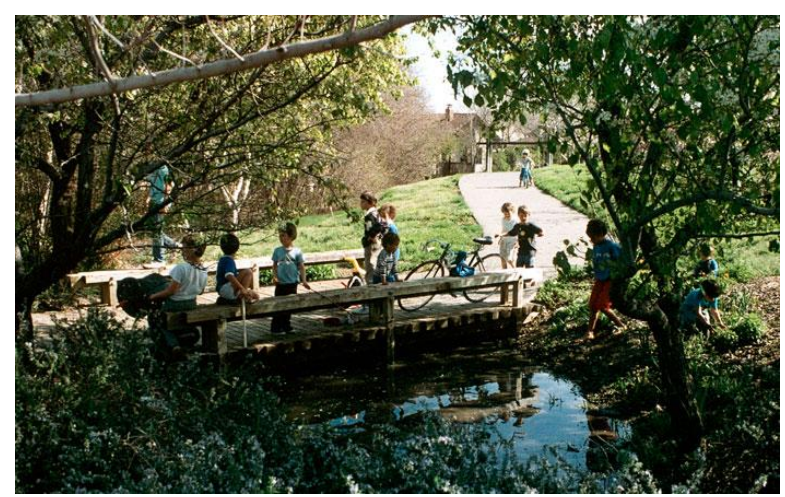

Figura 40. Crianças brincam em área verde onde é possível ver o sistema de drenagem natural. Fonte: PM Press, 2017.

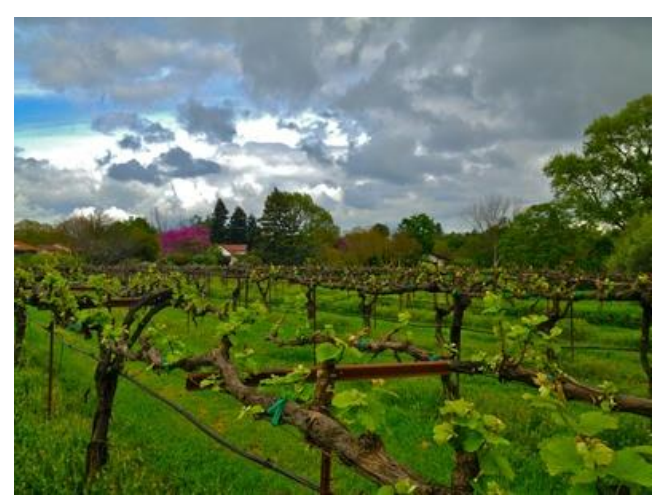

Figura 41. Área destinada à produção de alimentos. Fonte: Localwiki, 2017.

Analisando os princípios do urbanismo ecológico, em verde na tabela 06, podemos ver que Village Davis preenche a maior parte deles, só não cumprindo fatores ligados ao crescimento compacto, adensamento, diversidade de usos e mobilidade, colocando-a numa situação desconectada do entorno e do centro urbano mais próximo, característica essa muito comum aos projetos de ecovilas, que quase sempre ficam apartados da urbanização. Mas em questão aos aspectos de biofilia e infraestrutura verde ela cumpre seu papel, destacando-se como comunidade de cunho natural e ecológico. 


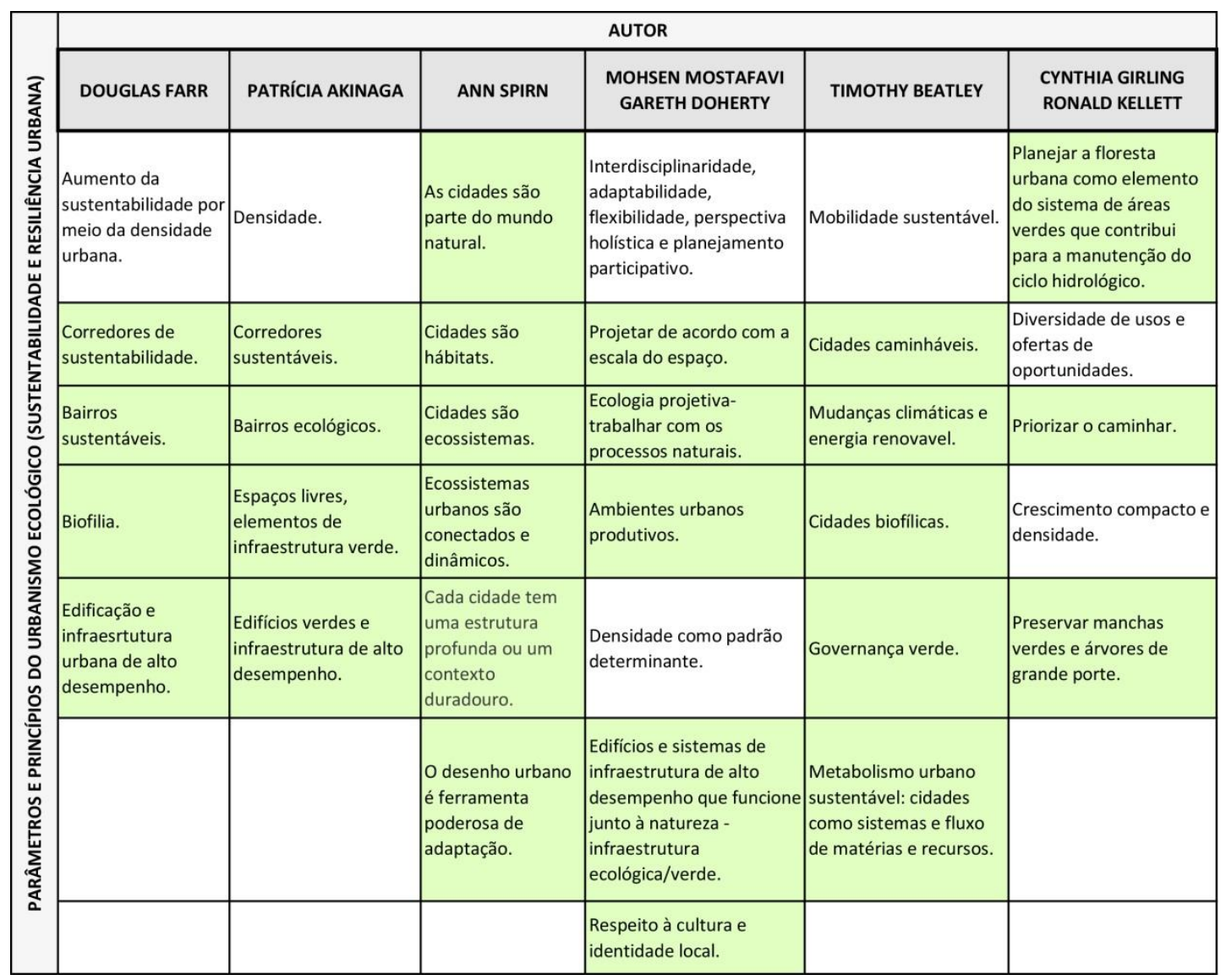

Tabela 06. Tabela dos princípios do urbanismo ecológico mostrando em verde os pontos atendidos no projeto de Village Davis. 


\section{CAPÍTULO 3}

\section{INFRAESTRUTURA VERDE COMO FERRAMENTA PARA O PLANEJAMENTO DA PAISAGEM.}

Infraestrutura verde é um dos conceitos mais utilizados nos últimos anos quando se fala de natureza na cidade. Ele considera que os sistemas naturais, através de seus processos ecológicos e ecossistêmicos, produzem diversos benefícios para o homem e a cidade e por isso podem ser igualados aos demais sistemas de apoio, ou infraestruturas, necessários ao bom funcionamento do espaço urbano. Nesse caso a paisagem é vista como reguladora dos processos ecossistêmicos que servem as necessidades humanas. (CZECHOWSKI, 2015).

Seus princípios abrangem desde a conectividade entre áreas verdes, sendo este fundamental à infraestrutura verde, passando por questões como avaliação do contexto onde a rede será implantada, comprometimento de longo prazo e respeito aos proprietários de terra e outras partes interessadas.

Exerce diversas funções que aqui serão agrupadas em três grandes grupos: a função ambiental, a função cívica e a paisagística. Também apresenta variadas escalas de implantação que vão desde grandes planos regionais a pequenos projetos de jardins residenciais.

\subsection{DEFINIÇÕES DE INFRAESTRUTURA VERDE}

A definição de infraestrutura verde é bem abrangente e inclui desde os fatores naturais, até os sociais e econômicos. A mais aceita e replicada no meio científico é dos autores Benedict e McMahon, que a apresenta como: 
florestas, habitats selvagens e outras áreas naturais; caminhos verdes, parques, áreas de conservação; fazendas, ranchos e florestas; desertos e outros espaços abertos que sustentam espécies nativas, mantém o processo ecológico natural, sustentam fontes de ar puro e reservas de água limpa e contribuem para a saúde e qualidade de vida para as pessoas e comunidades (...)". (BENEDICT; MCMAHON, 2001, p. 1, tradução nossa).

Karen Firehock, sobre o conceito, entende que: "ele é verde poque é parte do ambiente natural e é infraestrutura porque provêm os serviços básicos que todos nós precisamos para uma vida saudável". (FIREHOCK, 2015, p. 2).

Maria de Assunção Ribeiro Franco aponta sua interdisciplinariedade, que engloba áreas relacionadas ao Planejamento Urbano, Arquitetura da Paisagem, Ecologia, Geografia, Biologia, Conservação, Patrimônio e Transportes:

"No planejamento e desenho ambiental, a infraestrutura verde pode ser entendida como uma rede interconectada de áreas verdes naturais e outros espaços abertos que conservam valores e funções ecológicas, sustentam ar e água limpos e ampla variedade de benefícios para as pessoas e a vida selvagem e deverão nortear as ações de planejamento e desenvolvimento territoriais que devem garantir a existência dos processos vivos no presente e no futuro" (FRANCO, 2010, p.141).

Ainda segundo Franco (2010, p. 143), as redes de infraestrutura verde são compostas por "áreas permeáveis ou semipermeáveis, plantadas ou não, que prestam serviços à cidade com algum grau de manejo e gerenciamento público ou privado."

Patrícia Akinaga (2014) coloca que a infraestrutura verde pode ser entendida como conceito e como processo, ambos trazendo benefícios à sociedade. Como conceito, seu planejamento e gerenciamento levam à criação de redes de espaços livres voltados à presenação e recreação, formando uma malha verde. Como processo, auxilia na identificação das áreas a serem preservadas, devendo guiar o crescimento e desenvolvimento urbano. 
Cecília Herzog propõe a questão de trabalhar além dos elementos naturais, com engenharia de alta performance, que ajude a mitigar o impacto da urbanização, como fica claro no trecho abaixo:

"(...) é um modelo que procura mimetizar os processos naturais de modo a minimizar os impactos causados por urbanizações inadequadas ao suporte geobiofísico e possibilitar o planejamento sustentável de novas áreas e empreendimentos. A infraestrutura verde visa mitigar os efeitos da urbanização em diversas escalas e com equipes multidisciplinares, para que os aspectos abióticos, bióticos e sócio-culturais sejam balizadores de planejamentos e projetos integrados de médio e longo prazo." (HERZOG, 2010, p.3).

A autora considera também a importância dos espaços arborizados da cidade e de seus cursos d'água, não só para a ecologia da paisagem, mas também para a questão da qualidade de vida de seus habitantes:

"A infraestrutura verde é composta por redes multifuncionais de fragmentos permeáveis e vegetados, preferencialmente arborizados (inclui rios, canais, ruas e propriedades públicas e privadas) e interconectados, que reestruturam o mosaico da paisagem. Visa manter ou restabelecer os processos naturais e culturais que asseguram a qualidade de vida urbana.(...) Conexão é fundamental para os fluxos de água, biodiversidade e pessoas. A infraestrutura verde proporciona serviços ecossistêmicos ao mimetizar as funções naturais da paisagem, visa conservar e restaurar áreas ecológicas relevantes." (HERZOG, 2010, p.4).

A questão dos elementos de infraestrutura verde construídos também é apontada por Jack Ahern, que define o conceito como:

"sistemas espacial e funcionalmente integrados, rede de paisagens protegidas apoiadas por infraestrutura artificial, natural e híbrida, de ambientes construídos que provém serviços ecossistêmicos e de paisagem múltiplos, complementares para $\bigcirc$ público, para promover sustentabilidade". (AHERN, 2010, p.267, tradução nossa).

Jack Ahern e Paulo Pelegrino (2015) ressaltam a pluralidade de funções e serviços ecossistêmicos, tanto biofísicos como sociais, que são exercidos pelos sistemas de infraestrutura verde, colocando-as como muito mais eficientes do que a infraestrutura cinza convencional, unifuncional, de 
alto custo e também como importantes alavancas de sustentabilidade e resiliência urbana.

Outra importante faceta da infraestrutura verde é colocada pelos autores Czechowski, Hauck e Hausladen (2015), quando salientam a capacidade dos elementos da rede de infraestrutura verde de produzir alimentos saudáveis e energia limpa. Os mesmos autores também mostram seu valor como auxiliar na prevenção de enchentes, armazenamento de água e controladora dos processos naturais que servem o ser humano.

Diante dos conceitos acima explorados, podemos então colocar infraestrutura verde como uma rede conectada de áreas verdes que funciona na forma de sistema, considerando entre essas áreas verdes os elementos naturais e também os projetados, que visam o equilíbrio e conservação dos processos da paisagem, promovendo benefícios econômicos, sociais e culturais ao homem e à cidade. É constituída por projetos de baixo custo e alto desempenho (Herzog, 2010) que funcionam como suporte aos ecossistemas da paisagem urbana e também como provedores de biodiversidade.

\subsection{PRINCÍPIOS DA INFRAESTRUTURA VERDE}

São diversos os princípios contidos na conceituação e planejamento de redes de infraestrutura verde. Alguns autores os classificaram de forma muito eficiente e aqui mostraremos os mais relevantes. Karen Firehock (2015) aponta três princípios fundamentais da infraestrutura verde: suas estratégias protegem espécies animais e vegetais; sua abordagem tende a criar ecossistemas mais resilientes e suas estratégias permitem alcançar múltiplos objetivos de uma única vez.

Para Franco (2010), existem quatro princípios definidores da infraestrutura verde que deveriam nortear o planejamento transformando as funções do espaço urbano, sendo eles a conectividade, o contexto, a 
estrutura e o comprometimento. O primeiro, citado pela grande maioria dos autores e apontado como o mais importante princípio desses sistemas de infraestrutura natural, trata da conexão entre espaços naturais, parques e outros espaços abertos; ela é essencial para o desempenho da função intrínseca dos sistemas naturais e para perpetuar a vida selvagem. Nesse sentido, fortalece a idéia da conectividade apontando a necessidade da ligação linear entre parques arborizados que pode ser feita através de ruas verdes.

A importância da conectividade entre áreas verdes decorre do fato de que quando em conjunto, essas áreas formam um sistema que permite o equilíbrio e pleno funcionamento dos processos ecológicos. Baseia-se na Teoria da Ecologia da Paisagem defendida por Forman e Dramstad (1986). Os princípios dessa teoria mostram a importância de se conectar as diversas pequenas áreas verdes espalhadas no ambiente urbanos entre si e também às matrizes ecológicas. Como colocado pelos autores:

"(...) são princípios simples e holísticos que amarram
território, água, vida selvagem e pessoas. Como
planejadores urbanos devemos costurar essa rede de
mosaicos formados por manchas e corredores (...) para
impedir a paisagem de desmanchar." (DRAMSTAD, OLSON,
FORMAN, 1996, p.5, tradução nossa).

Os autores Mark Benedict e Edward McMahon apresentam dez princípios fundamentais da infraestrutura verde que "fornecem uma abordagem estratégica e uma estrutura para a conservação que possa promover o uso sustentável da terra enquanto beneficia as pessoas e a natureza". (BENEDICT; MCMAHON, 2006, p. 36). São eles:

1. Conexão é fundamental;

2. O contexto importa;

3. Infraestrutura verde deve ser fundamentada em ciência, teoria e prática do planejamento do uso da terra;

4. Infraestrutura verde pode e deveria funcionar como estrutura para conservação e planejamento; 
5. Deve ser projetada e mantida antes do desenvolvimento;

6. É um investimento público que deveria ser financiado a princípio;

7. Infraestrutura verde fornece benefícios para as pessoas e para a natureza;

8. Respeita as necessidades e desejos dos donos de terra e demais interessados;

9. Requer fazer conexões às atividades dentro e fora das comunidades e 10. Comprometimento de longo prazo.

Quando se trabalha com ecologia da paisagem o contexto é extremamente importante, pois a ecologia se baseia em processos e os mesmos não ocorrem isoladamente, dependem da interrelação das partes que compõe o todo, e é daí que decorre o princípio número 2. É importante avaliar o local do projeto e também suas bordas e áreas de influência, bem como os possíveis cenários de um futuro próximo, para que projeto e gerenciamento sejam bem fundamentados. (BENEDICT; MCMAHON, 2006).

A interdisciplinariedade em que se baseia o conceito já foi citada anteriormente e é um dos pontos colocados no terceiro princípio. Para complementá-la fica a importância de se utilizar o trabalho dos grupos de pesquisa dessas áreas e trabalhar com a ciência, de forma integrada, para que os projetos possam tirar proveito dos mais novos estudos e tecnologias. (BENEDICT; MCMAHON, 2006).

Os princípios 4 e 5 estão correlacionados e mostram que os projetos de infraestrutura verde tem base para funcionar como a estrutura de projetos de conservação e também de planejamento, sendo a base desses últimos e direcionando o desenvolvimento, antes que este aconteça, para que possa seguir em direção ambientalmente correta e sustentável. Em relação aos custos, especialistas apontam que as redes de infraestrutura verde deveriam ser financiadas pelo setor público e 
colocadas em igualdade de prioridade com as redes convencionais de infraestrutra, a infraestrutura cinza. (BENEDICT; MCMAHON, 2006).

Os benefícios conseguidos através da implantação desses projetos são tanto das pessoas quanto da natureza. A natureza se beneficia de redes que permitem o bom funcionamento e otimização de seus processos. Para as pessoas os benefícios são inúmeros. Além dos serviços ecossistêmicos já citados no capítulo 1 desse trabalho também tem-se a criação de uma rede de áreas de lazer e recreação, bem como a preservação de áreas importantes à conservação natural como patrimônio ambiental.

Sobre interesses particulares e propriedade das terras, a rede de infraestrutura verde não requer que todos seus elementos sejam de propriedade pública, respeitando assim a propriedade da terra particular. Desde florestas e áreas de preservação até pequenos quintais e ávores nas ruas são importantes para compor a rede, independente de sua propriedade legal. Também são importantes os diversos interesses envovlidos nos projetos, tanto do governo, das instituições de preservação, ONGs e dos proprietários de terra, sejam elas grandes ou pequenas propriedades. Dessa forma, os projetos terão maior apoio e serão mais aceitos pela população, que será sempre tratada como parceira no desenvolvimento desses planos. (BENEDICT; MCMAHON, 2006).

Como os projetos de infraestrutura verde vêem além de fronteiras políticas e funcionam como uma estrutura ecológica, é necessário que se considere, nos mesmos, as atividades que vão além de questões natrurais e que trazem a população para junto dos espaços verdes e de conservação, unindo iniciativas, por exemplo, de mitigação de enchentes, trilhas selvagens, fazendas urbanas e revitalização de terrenos contaminados, em atividades de dentro e fora das comunidades. (BENEDICT; MCMAHON, 2006).

O último princípio fala sobre o comprometimento de longo prazo já que estamos tratando de projetos que precisam de tempo para chegar 
ao seu ápice de funcionamento e para que seus processos atinjam o equilíbrio. Exigem também manutenção permanente e ferramentas que assegurem a continuidade dos projetos para além das gestões do governo. (BENEDICT; MCMAHON, 2006).

\subsection{FUNÇÕES DA INFRAESTRUTURA VERDE}

São diversas as funções dos sistemas de infraestrutura verde. Elas vêm atender às novas demandas da sociedade e do planejamento urbano não setorizado, através de conceitos que promovem a integração entre infraestrutura, tecnologia e natureza. Para melhor entendê-las, esse trabalho as reúne em três blocos sendo eles: ambiental, paisagístico e cívico.

\subsubsection{AMBIENTAL: OS SERVIÇOS ECOSSISTÊMICOS E A PAISAGEM} COMO MÁQUINA

As funções ambientais dos sistemas de infraestrutura verdes estão relacionadas aos serviços ecossistêmicos por eles produzidos. Como já colocado no capítulo 1.3.4, incluem a produção de alimento, água, combustíveis, serviços de regulação do clima, das enchentes, ciclos de nutrientes, benefícios estéticos, de lazer, culturais e espirituais.

Aqui a paisagem é vista como uma máquina com metabolismo em constante processo produtivo, onde $\mathrm{n}$ natural e o construído se desenvolvem na criação de sistemas abertos, que interagem com o seu exterior e caminham na direção da sustentabilidade. (RONCKEN; STREMKE; PULSELLI, 2015). 


\subsubsection{PAISAGÍSTICA: A REVALORIZAÇÃO DA PAISAGEM}

O dicionário apresenta paisagem como "espaço de terreno que se abrange num lance de vista". (FERREIRA, 1988). Já para a filosofia, ciência holística, é vista como o lugar da vida humana e não mais apenas como o espaço natural. (SERRÃO, 2011). É entidade que resulta da interação entre espaço natural e ação humana, não há paisagem sem a apropriação humana. Tem valor muito simbólico de conexão do homem com um ser criador, representa beleza e história, sendo palco de contemplação, apreensão estética que tem exercido, desde o princípio da história, fascínio sobre o homem. (HANNES, VIDOTE, CARAFA, 2016).

Ao longo dos tempos, com a criação das cidades e as mudanças nas relações do homem com a terra e com o espaço natural, a conexão homem e natureza se vê muito enfraquecida e a natureza não é mais vista como provedora de valor estético, cultural, filosófico e espiritual. (HANNES; FREITAS, 2016). Dessa relação deriva parte dos maus tratos aos elementos naturais e até mesmo sua subutilização, reduzindo seu valor à questão estética, de embelezamento do espaço urbano.

A implantação de um sistema de infraestrutura verde visa, entre outros aspectos, intermediar a reconexão do homem com a natureza, solidificando-a através da criação de espaços multifuncionais, experimentais, produtivos, híbridos, de alta performance e em sistemas abertos. (CZECHOWSKI; HAUCK; HAUSLADEN, 2015; MOHSEN; MOSTAFAVI, 2014).

É sabido que o verde valoriza muito as áreas urbanas e melhora a qualidade de vida, prova disso é que seus benefícios são vendidos em panfletos de empreendimentos imobiliários que se multiplicam pela cidade. A infraestrutura vede tem o potencial de multiplicar esses benefícios através da criação de redes de elementos naturais que permeiam todo o espaço urbano transformando a paisagem das cidades e sua forma urbana. É um tipo de desenho que torna visível as operações 
dos processos dos sistemas naturais, contribuindo para a experiência humana de estar conectado a eles. (SPIRN, 1988; SPIRN, 2011). Isso fica bem claro no trecho abaixo, de Kevin Lynch:

O prazer e o significado são necessidades humanas básicas, bem como o senso mental de conexão com a natureza, o aspecto mais profundo da sensibilidade (...) o movimento do sol e das marés, os ciclos de plantas daninhas, insetos e homens, pode também ser celebrado ao longo dos pavimentos da cidade". (Lynch 1981: 257).

A infraestrutura verde traz de volta ao homem o prazer de sentir a simplicidade do bem estar de se estar no contexto da paisagem e reforça seu valor quando escancara sua capacidade produtiva de bens e serviços que são essenciais à vida e à qualidade de vida. Como apontado por Hannes e Freitas:

"Essa reconexão não diz respeito apenas à natureza presente na cidade e sim à natureza da cidade, aquela que já se relaciona com o urbano e se desenvolve junto a ele, adaptada ao mesmo. Propiciar essa mudança de percepção em relação aos elementos naturais e ao seu valor enquanto elementos culturais formadores da paisagem urbana pode ser considerado o maior desafio da infraestrutura verde na atualidade." (2016, p. 1018).

\subsubsection{SOCIAL - URBANA: REDE DE ESPAÇOS LIVRES E MOBILIDADE}

\section{SUSTENTÁVEL}

A função social e urbana dos sistemas de infraestrutura verde está diretamente ligada à criação de redes de espaços livres, multifuncionais que permitam atividades de lazer, esportes, recreação e também que sejam produtivas, com incentivo à instalação de hortas urbanas. Esses espaços também podem, e devem, estar associados às redes de mobilidade sustentável com transporte público de massa que possibilitem a boa circulação das pessoas entre pontos de interesse da cidade e sempre ligados às redes de infraestrutura, verde e cinza, urbana. 
Os espaços da cidade podem contribuir de novas formas na composição dessa rede. Quintais de casas, vasos, tetos verdes e jardins privativos se transformam em jardins comunitários e produtivos, avenidas viram boulevares arborizados, com jardins filtrantes e ciclovias, canteiros centrais ganham pistas de caminhada e biovaletas (AKINAGA, 2014), linhas de alta tensão ganham ciclovias e áreas para desenvolvimento de agricultura urbana. São diversos os espaços urbanos subaproveitados que podem integrar a rede de infraestrutura verde dos bairros e cidades. (FARR, 2013).

Tais atividades aumentam a identidade cultural desses espaços, o sentimento de pertencimento dos cidadãos às comunidades, a participação popular na implantação e planejamento dos mesmos, aumentando e melhorando as relações sociais, a qualidade de vida e trazendo vivacidade a esses locais que também se tornam mais seguros, valorizados e atraentes. A infraestrutura verde pode, assim, trabalhar diretamente no aumento da qualidade de vida dessas pessoas, criando relações reais e significativas entre pessoas e lugares. (WALDHEIM, 2006). São projetos e paisagens que atendem às novas demandas da sociedade. Além disso, esses espaços naturais e construídos permitem uma melhoria da saúde física e mental de seus usuários, promovendo também melhoria em sua qualidade de vida. (COUTTS, 2016).

\subsection{PAISAGENS NATURAIS X PAISAGENS CONSTRUÍDAS}

Já foi apontado, nesse trabalho, que os sistemas de infraestrutura verde utilizam a paisagem como infraestrutura provedora de serviços ambientais ao homem e às cidades. O que se destaca agora é que esses sistemas podem ser naturais, como os rios e matas, ou construídos pelo homem, como as lagoas de contenção e os jardins de chuva. Constituem: 
"soluções multifuncionais e que apresentam desempenho potencializado quando utilizadas em forma de sistema e associadas a outras modalidades de infraestrutura urbana como mobilidade, captação e tratamento das águas urbanas". (HANNES; FREITAS, 2016).

Czechowski (2015) coloca que tais redes variam de estruturas existentes que passam por retrofit, a sistemas de infraestrutura tradicionais integrados aos elementos naturais, criando híbridos, máquinas. Roncken, Stremke e Pulselli (2015), citam as máquinas de paisagem, referindo-se a paisagens que recebem intervenção humana para aperfeiçoar seu funcionamento e produzir ou melhorar os processos que geram serviços ecossistêmicos.

As "paisagens construídas" utilizam a tecnologia e a engenharia para criar elementos que reconstituem, mimetizam os elementos naturais e seus serviços ecossistêmicos. Como exemplo desses elementos pode-se citar os mais conhecidos e utilizados nos projetos espalhados pelo mundo, como os jardins de chuva (figura 42), as biovaletas (figura 43), lagoas pluviais (figura 44), canais naturalizados ou seminaturalizados (figura 45), wetlands (figura 46), telhados verdes (figura 47), muros verdes (figura 48) e outros. Dos elementos naturais podemos citar as áreas verdes, arborização urbana, floresta urbana e recursos hídricos, sendo eles rios, córregos, lagos e áreas alagadas. Os benefícios atrelados a cada um desses elementos podem ser vistos na tabela 07 abaixo.

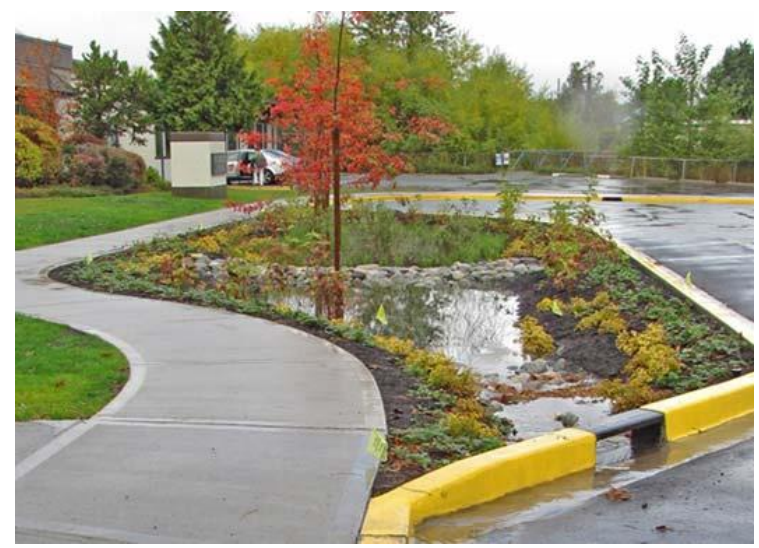

Figura 42. Jardim de chuva na cidade de Seattle. Fonte: Web Atlas of Landscape Architecture of British Columbia, 2009.

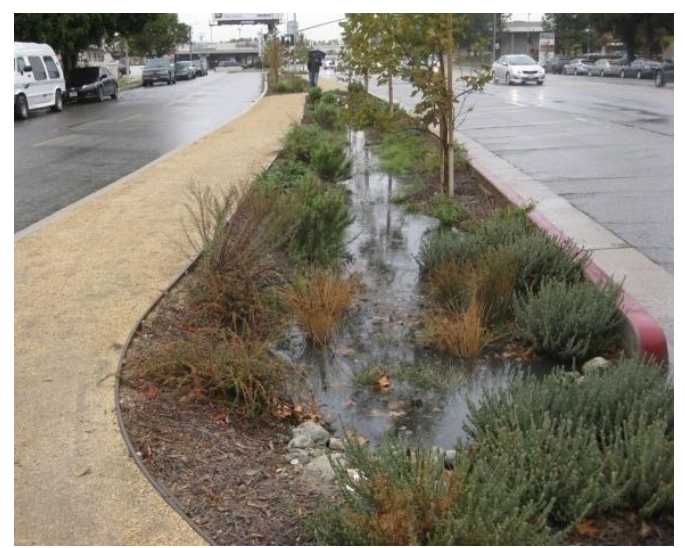

Figura 43. Biovaleta na cidade de Los Angeles. Fonte: Los Angeles Department of Water and Power, 2015. 


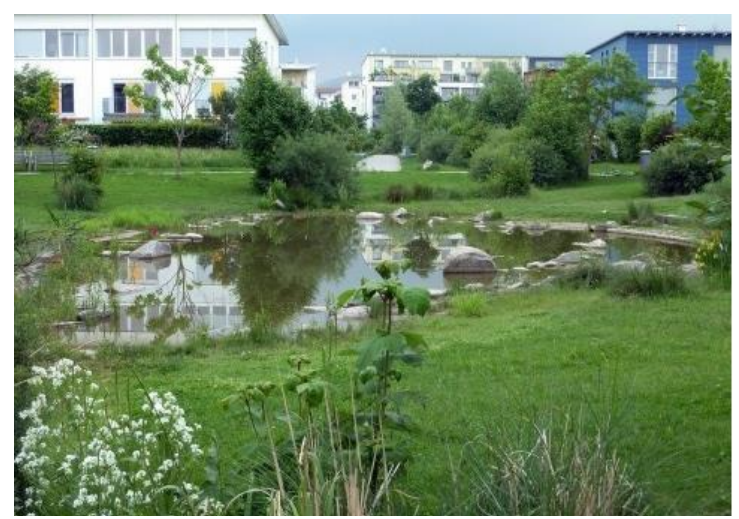

Figura 44. Lagoa pluvial em Frieburg. Fonte: Cecília Herzog, 2011.

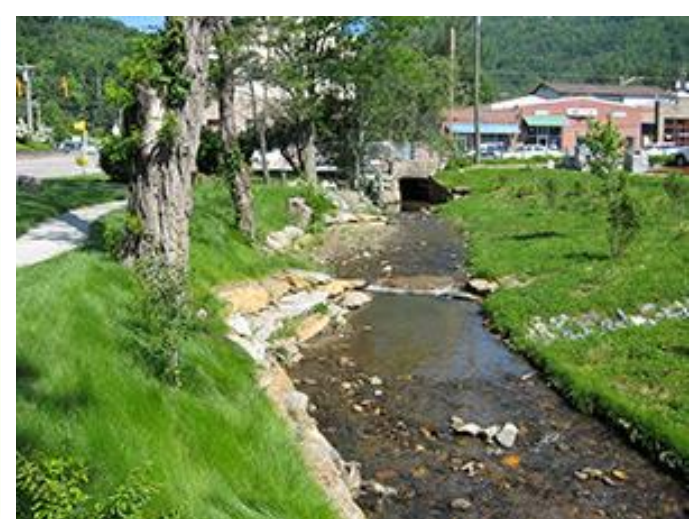

Figura 45. Córrego renaturalizado. Fonte: ASU News, 2013.

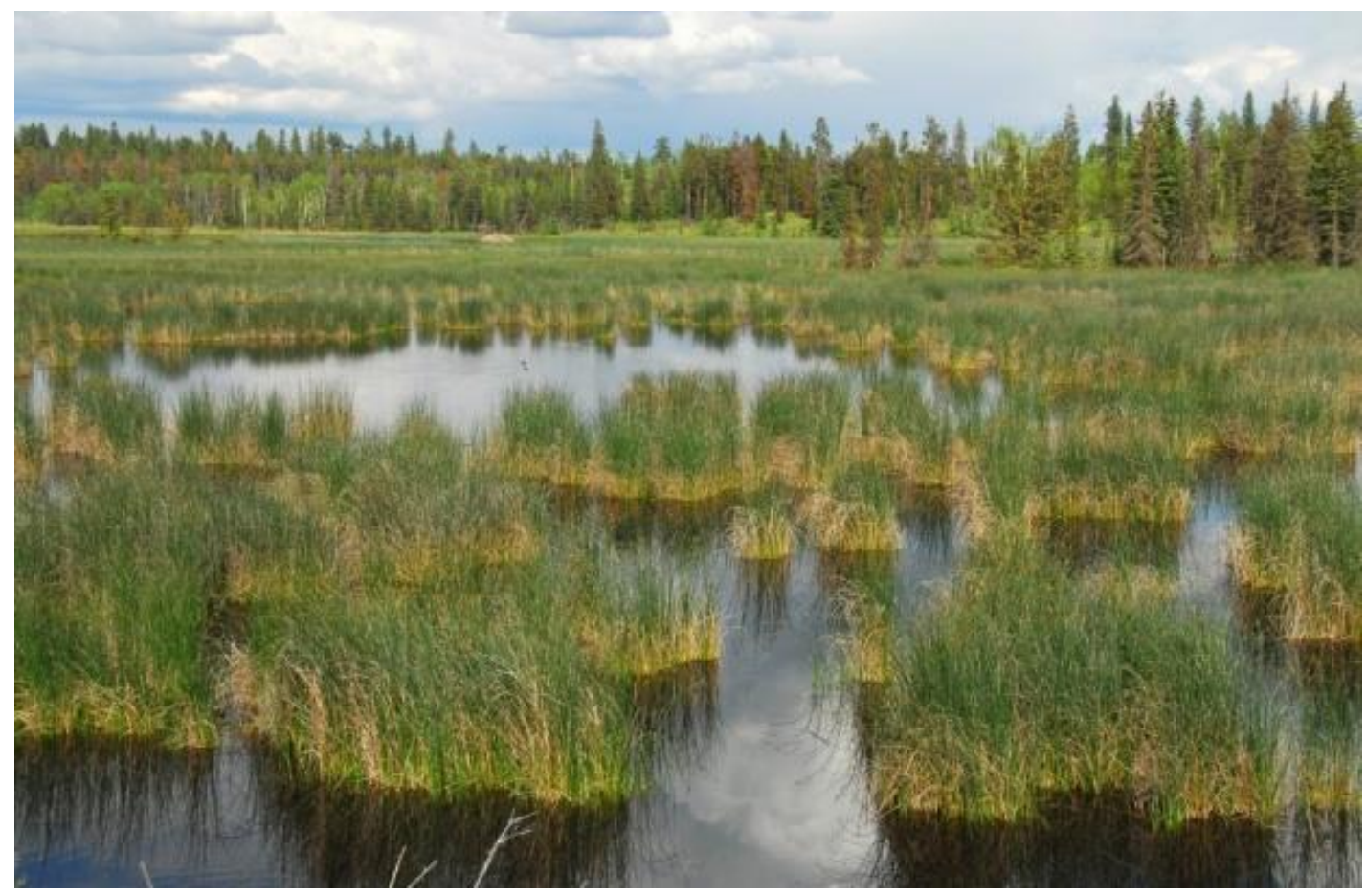

Figura 46. Wetland. Fonte: Great Lakes Inform, 2017.

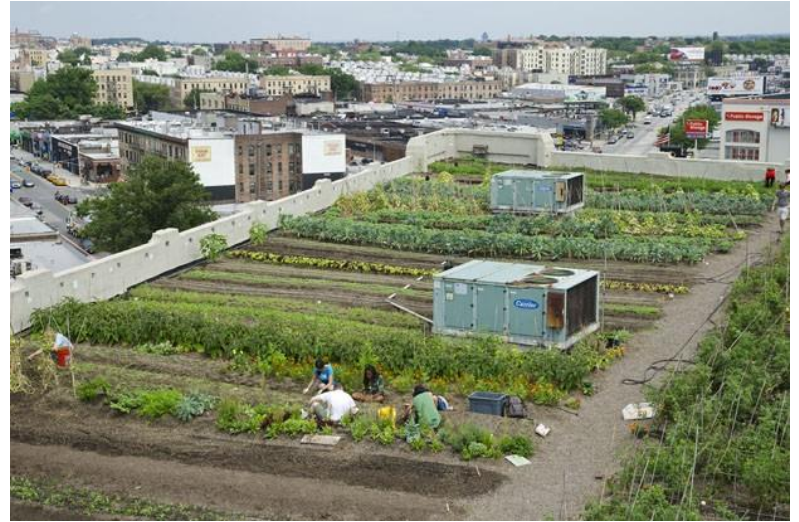

Figura 47. Teto verde com horta. Fonte: Haroldo Castro, Revista Época, 2016.

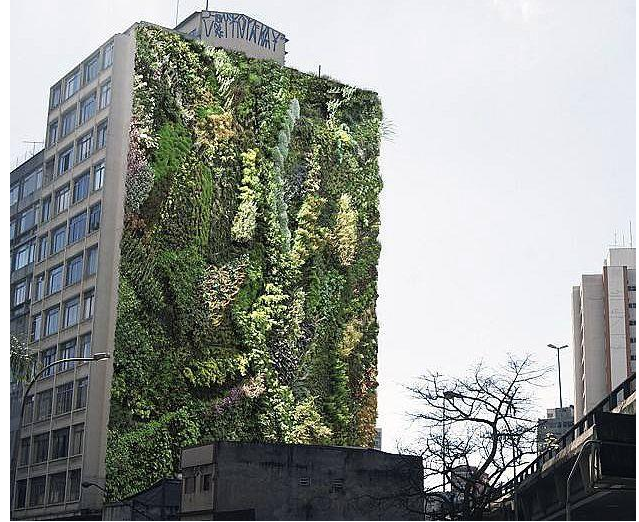

Figura 48. Parede verde próxima ao minhocão, São Paulo. Fonte: Movimento 90, 2016. 


\begin{tabular}{|c|c|c|c|c|c|c|c|c|c|c|c|c|c|c|c|c|}
\hline & 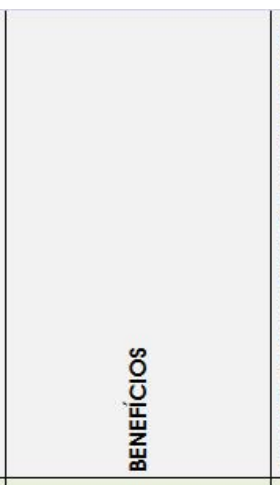 & 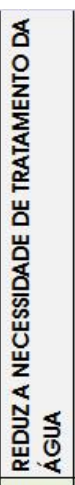 & 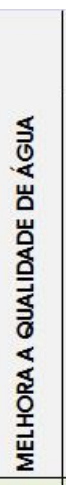 & 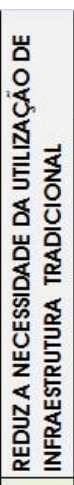 & 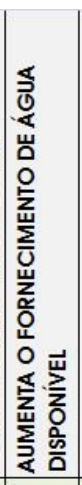 & 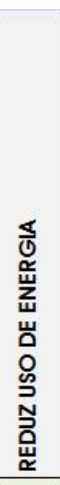 & 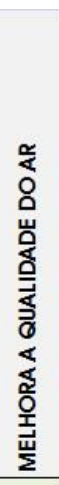 & 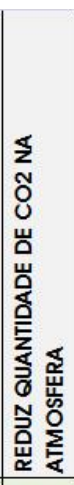 & 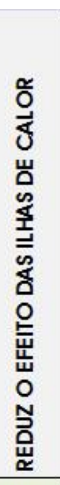 & 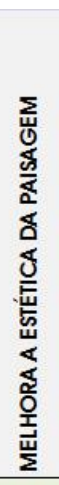 & 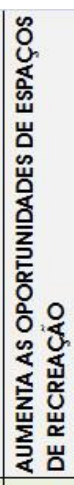 & 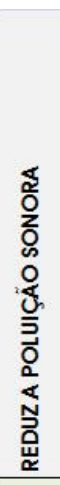 & 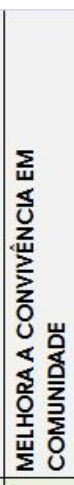 & 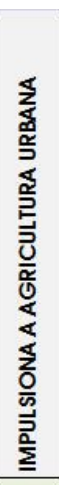 & 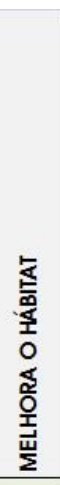 & 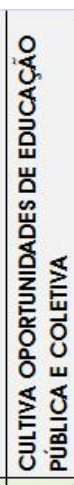 \\
\hline \multirow{8}{*}{8} & JARDIM DE CHU & + & + & + & + & - & + & + & + & + & - & - & - & - & + & + \\
\hline & BIOVALETA & + & + & + & + & - & + & + & + & + & - & - & - & - & + & + \\
\hline & LAGOAS PLUVIAIS & + & + & + & + & - & + & - & + & + & + & - & + & - & + & + \\
\hline & CANAIS NATURALIZADOS & + & + & + & + & - & + & - & + & + & + & - & + & - & + & + \\
\hline & WETLANDS & + & + & + & + & - & + & $1 / 2$ & + & + & + & - & + & - & + & + \\
\hline & TELHADOS VERDES & $1 / 2$ & $1 / 2$ & + & - & + & + & + & + & + & - & + & - & + & + & + \\
\hline & MUROS VERDES & $1 / 2$ & $1 / 2$ & + & $1 / 2$ & + & + & + & + & + & - & + & - & + & + & + \\
\hline & AGRIC & $1 / 2$ & $1 / 2$ & + & $1 / 2$ & 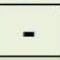 & + & + & + & + & + & + & + & + & + & $t$ \\
\hline \multirow{6}{*}{ 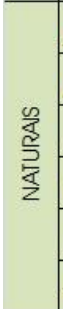 } & ARBORIZAÇĀO & + & + & + & + & + & + & + & + & + & - & + & + & $1 / 2$ & + & + \\
\hline & AREAS VERDES & + & + & + & + & + & + & + & + & + & + & + & + & $1 / 2$ & + & $t$ \\
\hline & CORREGC & + & + & + & + & - & + & - & $1 / 2$ & + & + & - & + & - & + & + \\
\hline & RIOS & + & + & + & + & - & + & - & $1 / 2$ & + & + & - & + & - & + & + \\
\hline & LAGOS & + & + & + & + & + & + & - & + & + & + & - & + & - & + & + \\
\hline & WETLANDS & + & + & + & + & - & + & $1 / 2$ & + & + & + & - & + & - & + & + \\
\hline
\end{tabular}

Tabela 07. Benefícios ligados aos elementos de infraestrutura verde. Com sinal de + estão os que possuem o benefício, 1/2 os que talvez apresentem e - os que não apresentam.

\subsection{ESCALAS DA INFRAESTRUTURA VERDE}

Como já citado anteriormente, a infraestrutura verde abrange as mais variadas escalas, contemplando desde complexas redes regionais de conservação e ecologia da paisagem até elementos singulares como jardins de chuva e telhados verdes. Os autores Benedict e McMahon abordam a questão da seguinte forma:

"(...) O termo significa diferentes coisas dependendo do contexto no qual ele é empregado: pode ser desde o plantio de árvores que tragam benefícios ecológicos em áreas urbanas; para outros se refere a estruturas de engenharia tais como manejo de enchentes ou tratamento de águas projetado para tornar-se 
ambientalmente amigável. No entanto infraestrutura verde pode ter um significado mais ambicioso e abrangente". (BENEDICT; MACMAHON, 2001, p. 1, tradução nossa).

A escala utilizada depende dos objetivos do projeto. (FIREHOCK, 2015). Um projeto que visa proteger as dunas da praia exige uma escala muito maior do que um projeto que visa mitigar enchentes em um único ponto ou terreno da cidade, que também trabalhará em uma escala diferente, menor, do que um projeto de prevenção de enchentes em uma bacia hidrográfica ou rio por completo.

De qualquer forma, para trabalhar em projetos de ecologia da paisagem, que pressupõe a ideia de processos, é necessário que se olhe sempre para uma escala além da trabalhada, considerando os aspectos naturais a ela relacionados, para que se possa determinar como a área se encaixa nos sistemas ecológicos nela envolvidos, como rotas de migração de animais, fluxos d'água, bacias hidrográficas e outros. (FIREHOCK, 2015)

\subsection{INFRAESTRUTURA VERDE COMO FERRAMENTA POTENCIAL}

\section{PARA COMUNIDADES ECOLÓGICAS}

Os sistemas de infraestrutura verde podem agregar diversas características ecológicas e sustentáveis aos projetos de bairros e vilas, bastando avaliar seus elementos, princípios e conceitos para entender como isso é possível. No capítulo 2, ao estudar bairros ecológicos e ecovilas e analisar alguns exemplos dos mesmos, vimos como essas unidades urbanas fazem extensivo uso dos elementos de infraestrutura verde e tomam os mesmos como fatores indutores de sustentabilidade $e$ de planejamento ecológico, como pode ser observado na tabela 08.

O bairro de Vauban faz uso de técnicas de biorretenção das águas das chuvas através do uso de biovaletas, utiliza telhados verdes como forma de amenização climática, tem jardins coletivos que incentivam o convivio comunitário, hortas coletivas que produzem alimentos e são 
cuidadas pelos moradores, tem área de preservação nas margens do curso d'água que está em um de seus limites permitindo assim a conexão desse bairro com outros espaços verdes e perpetuando as trocas ecológicas. Faz também intenso uso de arborização urbana.

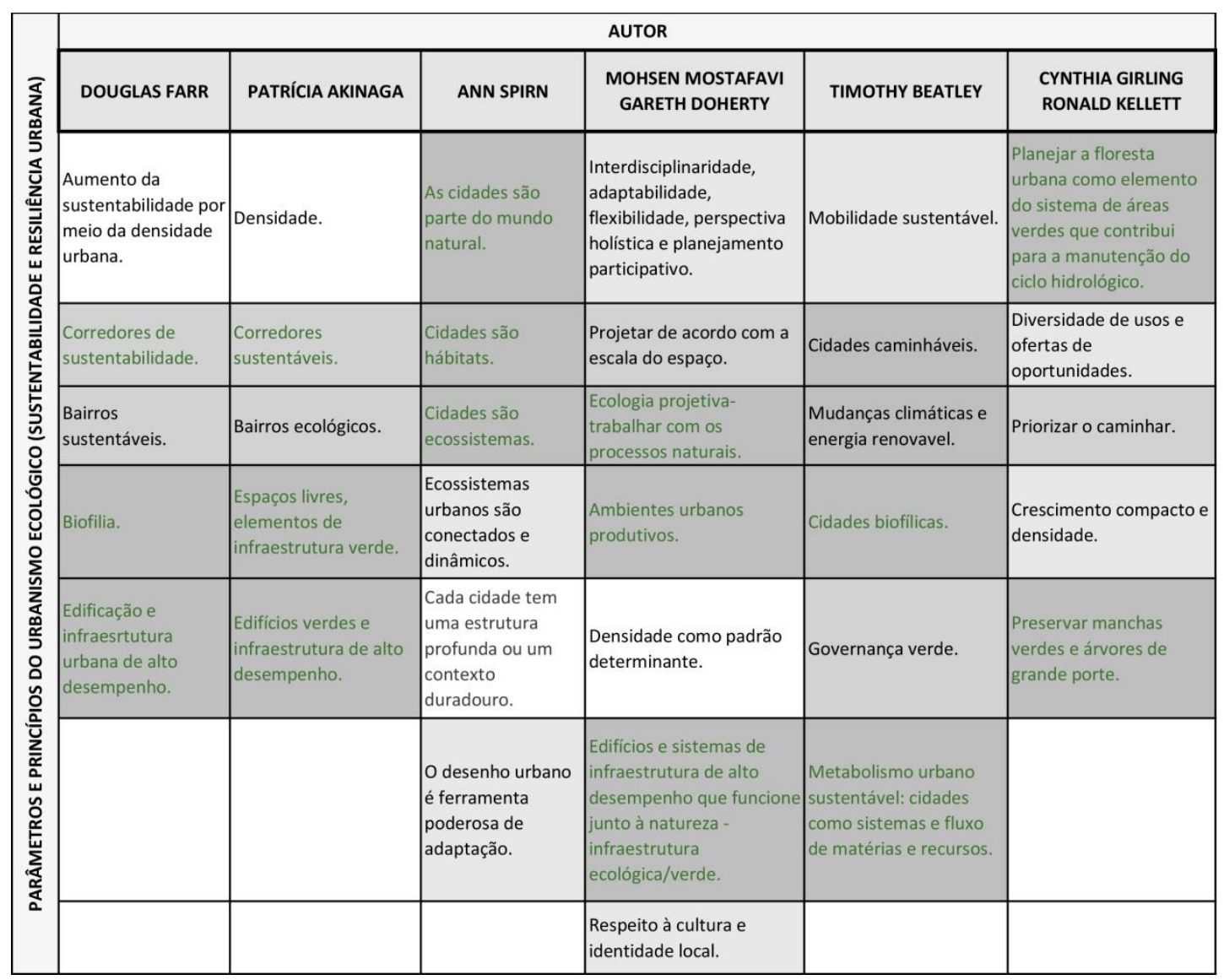

Tabela 08. Princípios do urbanismo ecológico mostrando sua ligação com conceitos de infraestrutura verde e sua utilização nos estudos de caso trabalhados no capítulo 02.

O plano para a remodelação do Southwest District apresenta um capítulo específico que trata do tema infraestrutura verde. Utiliza diversos de seus conceitos e elementos como: captação de água nos telhados, jardins de chuva, biovaletas, superfícies permeáveis que permitem a recarga do lençol freático e contribuem com a diminuição de enchentes, cobertura arbórea que ajuda a reduzir os efeitos da ilha de calor e melhora o habitat da avifauna, criação de corredores verdes ecológicos ligando 
parques existentes e novos, tetos verdes com espécies comestíveis e paredes verdes. Apresenta estratégias específicas para a escala do quarteirão e do distrito, nunca vendo o projeto como limitado e desconexo do entorno e de uma macro escala.

Findhorn tem em sua filosofia a preservação e conexão com os elementos naturais, o que já evidencia seu caráter naturalista. Faz uso de alguns elementos de infraestrutura verde como telhado verde, jardins e hortas comunitárias, preservação da permeabilidade do solo e cobertura vegetal, tratamento biológico do esgoto e da água utilizada na ecovila.

A Ecovila Davis mostra, desde suas ideias iniciais, a preocupação com o planejamento ambiental. Uma das diretrizes principais na criação do projeto foi planejar uma rede exclusiva de passeios de pedestres que conecta as áreas verdes da vila, criando assim um sistema verde interligado que permite o livre fluxo de pessoas, animais e matéria. Essas áreas verdes são compostas de quintais comunitários, praças e áreas de plantio coletivo. Nesses espaços são utilizadas biovaletas que fazem a captação e distribuição das águas das chuvas para lagoas de retenção. A arborização urbana também tem papel de destaque no projeto contribuindo para a amenização das temperaturas nos espaços externos.

Fica assim claro como os projetos analisados misturam os sistemas de infraestrutura verde com elementos tradicionais de infraestrutura dos serviços de energia, água e resíduos para melhorar o ambiente construído, a qualidade de vida e a conexão do homem com a natureza, contribuindo para o desenvolvimento de comunidades mais sustentáveis, equilibradas, resilientes e ecológicas. 
PARTE II. ANÁLISE TERRITORIAL DA PAISAGEM: BACIA DO CÓRREGO DO ÍNDIO E VILA AMÉLIA 


\section{CAPÍTULO 4}

\section{CARACTERIZAÇÃO FÍSICO AMBIENTAL DO TERRITÓRIO}

Para que a ocupação humana e as intervenções urbanas e arquitetônicas na paisagem possam ser realizadas e obtenham sucesso é necessário que se conheça bem o território onde as mesmas irão ocorrer e suas dinâmicas. Diferentes relevos pedem diferentes tipos de ocupação e trato com o suporte físico, bem como diferentes climas impactam diretamente na forma de se construir cidades. O território está em constante dinâmica com os processos ecológicos e esses, por sua vez, o alteram: rios têm suas cheias e secas, meandros mudam de posição alterando a configuração das planícies aluviais, escarpas montanhosas sofrem com deslizamentos e assim por diante.

O movimento do sol e dos ventos, associados à orientação das ruas, dos espaços livres e construídos, criam novas realidades e condições que alteram o clima urbano. A forma de ocupação imposta pelo homem no território, seus padrões de consumo e cultura também tem impacto sobre o solo e elementos naturais da paisagem, o que gera influência direta na saúde humana. Conhecer e respeitar os processos da natureza é fundamental para a segurança e resiliência dos núcleos urbanos.

O ecologicamente correto nunca esteve tão na moda como nos tempos atuais, a era do combate ao aquecimento global. Mas muitas vezes, o que se diz sustentável ou ecológico, não passa de projetos maquiados que incorporam algumas diretrizes paisagísticas diferenciadas, como tetos verdes, paredes verdes, ou também itens isolados de certificações sustentáveis. Como exemplo, podemos citar o bairro planejado Jardim das Perdizes, na Barra Funda, que vende a ideia de bairro sustentável sem apresentar ao menos uma diretriz que considere as características e dinâmicas da área onde está implantado, a várzea do Tietê e seus problemas com enchentes. Isso sem fazer menção ao fato de 
O terreno estar na lista dos contaminados da Companhia Ambiental do Estado de São Paulo, a CETESB. (CETESB, 2015).

O geógrafo José Guilherme Schutzer afirma que, apesar de a questão ambiental ter ganhado enfoque nos últimos anos, os projetos de intervenção no território ainda exibem soluções simplistas, parciais, que não consideram as dinâmicas da paisagem e a relação dessas com o ambiente natural e construído. (SCHUTZER, 2012).

Schutzer coloca que, para melhorar a qualidade ambiental e reestabelecer o equilíbrio entre processos naturais, urbanos e humanos é necessário reconsiderar as questões geográficas e o relevo, propondo a utilização da metodologia de análise do espaço delineada por Ab'Saber (1969) que se baseia em três conceitos: a compartimentação do relevo; a estrutura superficial da paisagem e a fisiologia da paisagem. Dessa análise se origina um mapa de zoneamento ambiental que representa as potencialidades naturais e urbanas de cada compartimento determinado e que pode ser aplicada em escalas diversas. (SCHUTZER, 2012).

\subsection{LOCALIZAÇÃO}

Como unidade de análise esse trabalho adota a escala da bacia hidrográfica, pois entende que ela é a mais indicada para a análise dos processos e dinâmicas da natureza. Assim sendo, trabalharemos a subbacia do córrego do Índio, que tem suas nascentes localizadas na Vila Amélia e Horto Florestal. Essa sub-bacia é contribuinte da bacia do córrego Guaraú, que por sua vez, contribui com a bacia do córrego Cabuçu de Baixo, localizada à margem direita do Tietê, na zona norte do município de São Paulo, como mostra a figura 49. A figura 50 mostra as sub-bacias que formam a bacia do Cabuçu de Baixo, incluindo a sub-bacia do Guaraú, em laranja. 


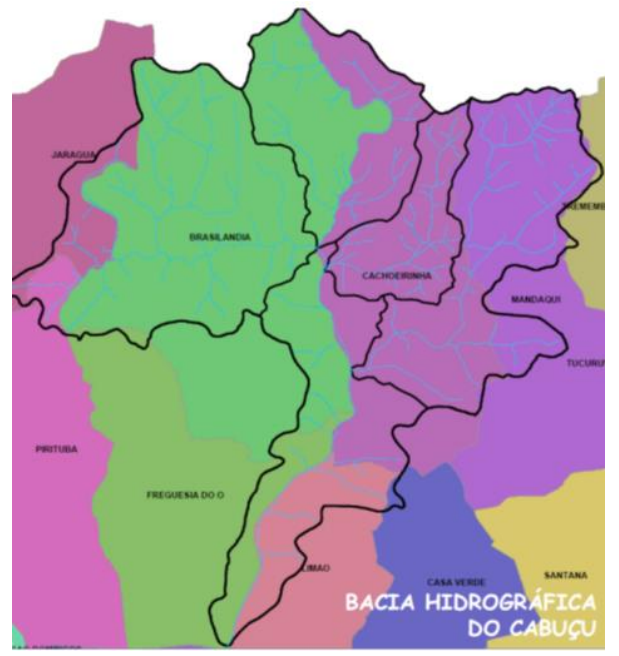

Figura 49. Localização da bacia hidrográfica do córrego Cabuçu de Baixo. Fonte: Bertocco et. al., 2009.

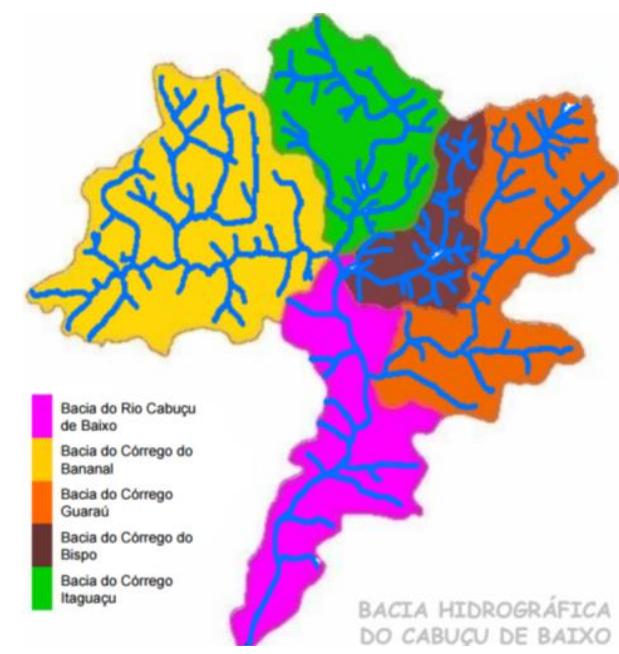

Figura 50. Bacia hidrográfica do córrego Cabuçu de Baixo e suas sub-bacias constituintes, com a sub-bacia do Guaraú em laranja. Fonte: Bertocco et. al., 2009.

A imagem 51 mostra a sub-bacia do córrego do Índio e a bacia do córrego Guaraú, do qual faz parte, sobre imagem satélite da região. Nela podemos observar a Vila Amélia localizada dentro da mancha verde do Horto Florestal. Na imagem 52 podemos observar uma ampliação da imagem anterior com a sub-bacia do córrego do Índio, a Vila Amélia inserida na área do Horto Florestal e uma linha laranja que mostra a divisão das áreas dos distritos do Mandaqui à direita e da Cachoeirinha à esquerda, com o bairro da Vila Amália.

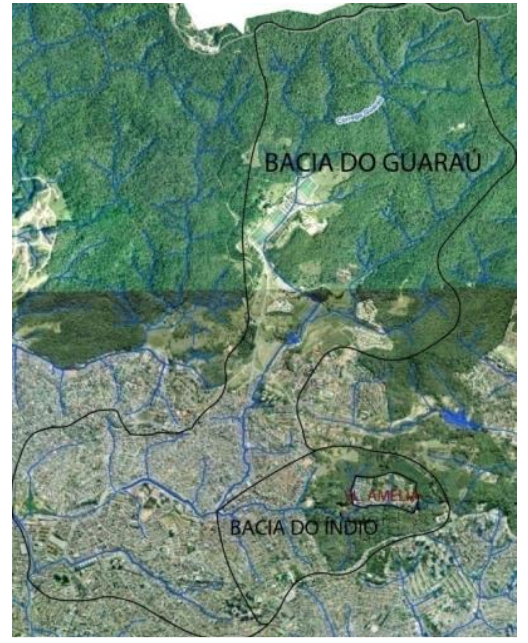

Figura 51 (a esquerda). Bacia do Guaraú e sub-bacia do Índio. Fonte: Trabalho da autora sobre imagem geomapas.

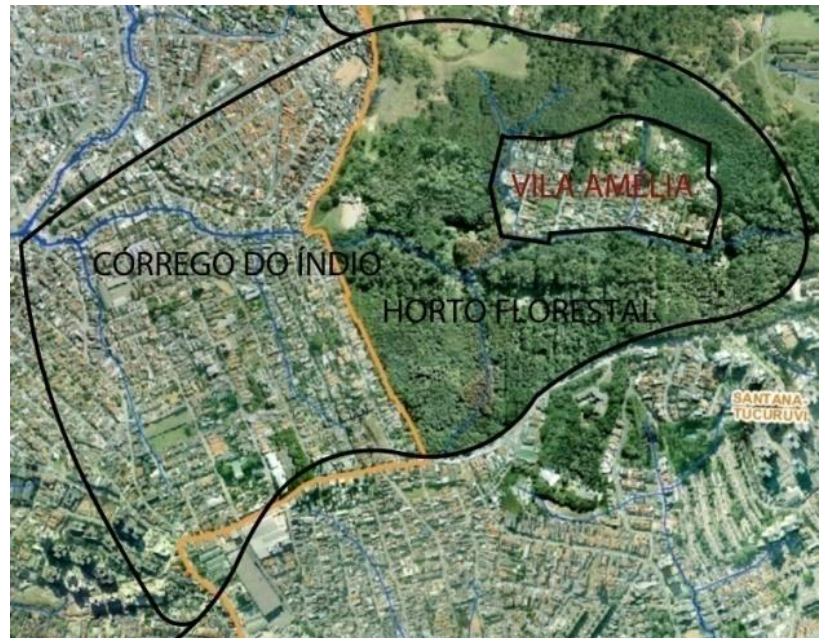

Figura 52 (abaixo). Sub-bacia do Índio, Vila Amélia, Horto Florestal e limite de subprefeituras em laranja. Fonte: Trabalho da autora sobre imagem geomapas. 


\subsection{CLIMA}

A área da bacia hidrográfica do córrego do Índio está inserida na unidade climática natural do clima Tropical Úmido de Altitude do Planalto Atlântico, nas colinas intermediárias e morros baixos do além Tietê, configurando situação topográfica intermediária entre as várzeas aluviais e os topos de morros mais altos, com variação de altitude entre 740 e 820 metros. Essa configuração topográfica acarreta um leve aquecimento na temperatura apresentando médias anuais entre $19,3^{\circ}$ a 19,6 $6^{\circ}$, médias máximas anuais entre $24,9^{\circ}$ a $25,2^{\circ}$ e médias mínimas anuais entre $15,5^{\circ}$ e $15,8^{\circ}$. Por estar associada aos topos de morro, principalmente à área instável da Serra da Cantareira e Jaraguá, essa unidade climática tem altos índices pluviométricos, que variam entre 1350 e 1580 mm. Também favorecem a drenagem noturna de ar frio, criando baixas inversões térmicas que possibilitam considerável dispersão de poluentes. (ATLAS AMBIENTAL DE SÃO PAULO, 2000).

\subsection{COBERTURA VEGETAL}

A área estudada se insere no Domínio Morfoclimático Brasileiro de Mares e Morros no qual predominam florestas tropicais biodiversas, com domínio da biota da Mata Atlântica, que já chegou a ocupar 16\% do território nacional. Hoje contamos apenas com $7,3 \%$ de sua área original. (IBAMA / MMA, 2008). A cobertura vegetal hoje presente no município de

São Paulo é representada por fragmentos de vegetação natural secundária que resistiram e se regeneraram após os distúrbios causados pelo processo de urbanização. (ATLAS AMBIENTAL DE SÃO PAULO, 2000).

Salvo a área pertencente ao Horto Florestal, no restante da área da bacia do córrego do Índio não se encontra considerável presença de vegetação. Cerca de $25 \%$ da área está conformada no subgrupo Urbano 
1 da classificação do Atlas Ambiental do Município de São Paulo (em vermelho na figura 53) que é constituída por regiões com densa urbanização e escassez de vegetação, com grande quantidade de prédios, vias pouco arborizadas e carência de praças e jardins residenciais. Outros 20\% da área compreende o subgrupo Urbano 2 que abrange regiões com densa urbanização e escassez de vegetação, diferenciando-se do grupo Urbano 1 pelo predomínio de bairros residenciais horizontais adensados, com vias ainda pouco arborizadas, também com carência de praças e jardins residenciais. 10\% da área corresponde à ocupação da Vila Amélia e encaixa-se no subgrupo Urbano 3, representado por regiões intensamente arborizadas, bairros jardim e áreas de expansão urbana.
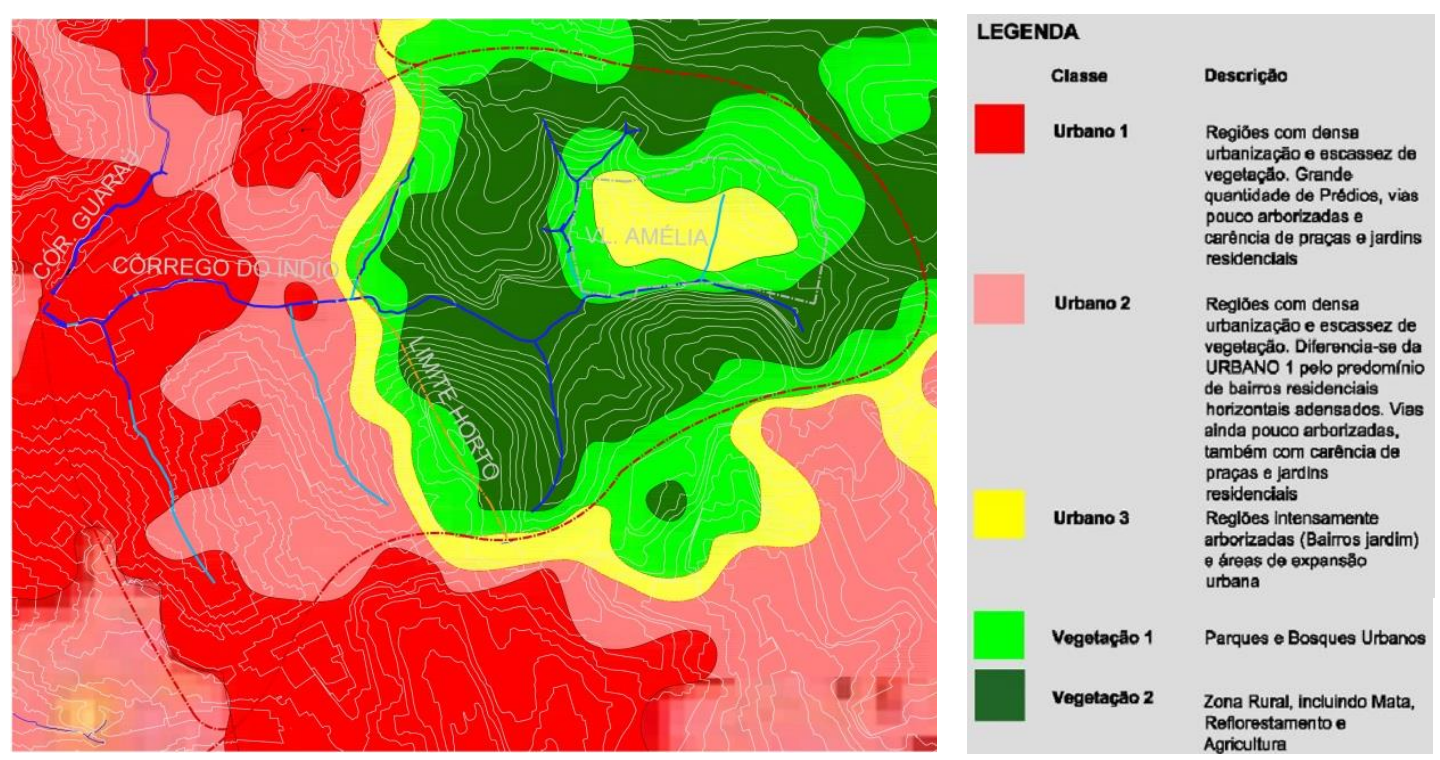

Figura 53. Mapa de distribuição da vegetação do Atlas Ambiental do Município de São Paulo onde a linha tracejada vermelha representa a bacia hidrográfica do córrego do Índio, a linha tracejada laranja mostra o limite do Horto Florestal, a linha tracejada cinza mostra a Vila Amélia. Trabalho da autora sobre imagem do Atlas Ambiental.

O restante da área está compreendida nos limites do Horto Florestal de São Paulo, compreendendo os subgrupos Vegetação 1 e 2 da classificação do Atlas Ambiental, sendo que o primeiro encerra parques e bosques urbanos e corresponde à parte da área do bairro da Vila Amélia. O subgrupo Vegetação 2, classificado como zona rural, incluindo mata, 
reflorestamento e agricultura compõem-se do restante da área correspondente à mata do Horto Florestal nesse recorte. (ATLAS AMBIENTAL DE SÃO PAULO, 2000).

Os mapas do documento "A Vegetação Significativa do Município de São Paulo" (SVMA, 1988), na figura 54, deixam clara a ausência de vegetação na área, que tem como destaque a área verde do Parque Estadual Alberto Lofgren, o Horto Florestal. Além dessa mancha, apenas pequenos fragmentos verdes se fazem presentes, como uma praça marcada com Chr, chácaras remanescentes, entre as ruas Koshun Takara e Santa Lucrécia de Aguiar, hoje já com partes ocupadas por galpões e um conjunto residencial; pequeno conjunto arbóreo na EMEF Osvaldo Quirino Simões e UBS Vila Dionisia (Es), dois pontos com Paineiras (pa) e um trecho de jardins residenciais $(\mathrm{J})$. O mapa mostra ainda duas porções de glebas não ocupadas (Gi) em áreas urbanizadas, mas estas, hoje, já se encontram ocupadas.

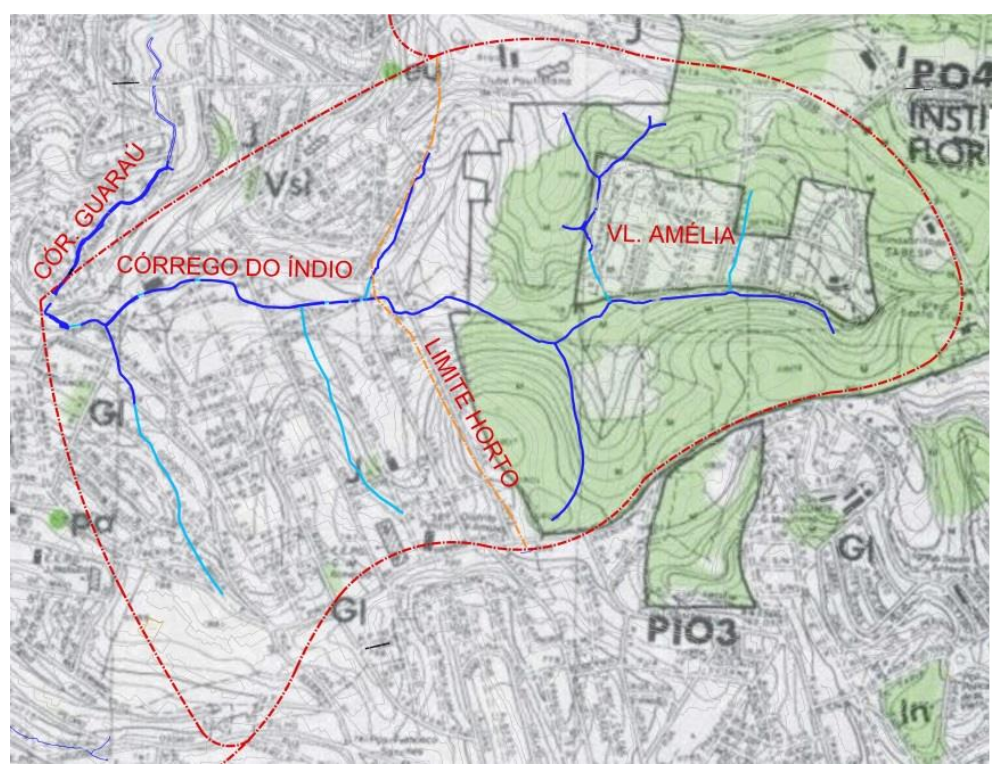

Figura 54. Mapa da Vegetação Significativa do Município de São Paulo onde a linha tracejada vermelha representa a bacia hidrográfica do córrego do Índio, a linha tracejada laranja mostra o limite do Horto Florestal, a linha tracejada cinza mostra a Vila Amélia. Trabalho da autora sobre imagem da Vegetação Significativa de São Paulo.

Em uma comparação entre essa publicação e foto aérea do Google, percebemos que, apesar de apresentar ainda inexpressiva quantidade de cobertura vegetal além da mata do Horto, a situação se mostra um pouco melhor do que nos levantamentos da Vegetação 
Significativa de 1988. É possível perceber maior arborização em jardins residenciais, ao longo dos cursos d'água, nos conjuntos habitacionais e nas escolas.

As áreas de vegetação significativa no entorno consistem na Invernada da polícia Militar, a leste do Horto, fazendo limite com o e mesmo; a sudeste a área da Ama do Mandaqui, o Parque da Juventude e o Campo de Marte; a sudoeste o Cemitério Nova Cachoeirinha e a norte o Parque Estadual da Serra da Cantareira, sendo essa última a mais expressiva. São manchas verdes que poderiam ser conectadas aos fragmentos presentes no recorte de estudo configurando uma matriz verde dos bairros da Casa Verde e Cachoeirinha.

O Horto Florestal, Parque Alberto Loefgren, apresenta considerável cobertura vegetal e muita diversidade de fauna e flora, no meio do qual está inserido o bairro da Vila Amélia. Conserva uma floresta de Araucárias, espécie ameaçada e protegida por lei, exemplares da Mata Atlântica como o jatobá, pau-brasil, carvalho nacional, pau-ferro entre outras, espécies exóticas como o pinheiro do brejo e o eucalipto. (SECRETARIA DO MEIO AMBIENTE, 2016). E o mais importante é que está junto à matriz ecológica da Cantareira, exercendo importante papel como núcleo ecológico na cidade de São Paulo.

\subsection{NASCENTES E CURSOS D'ÁGUA:}

A bacia hidrográfica do córrego do Índio é uma das sub-bacias que formam a bacia do córrego Cabuçu de Baixo e, o córrego do índio, um dos afluentes do córrego do Guaraú, que possui papel no tratamento das águas da cidade de São Paulo devido à estação de tratamento de águas do Guaraú. Apresenta área de drenagem aproximada de $1.539 .000 \mathrm{~m}^{2}$ ou $1,5 \mathrm{~km}^{2}$ de extensão. 
Suas nascentes ficam dentro da área do Horto Florestal, em região coberta de vegetação, próxima à Vila Amélia, Rua Tomé Afonso de Moura e Avenida Santa Inês, estando apenas duas delas em área externa ao parque e, hoje, urbanizadas. Corre pelo limite urbanizado da VI. Amélia, separada desta por muro, que também protege a mata do Horto, passando por seu acesso oeste, na Rua Gal. Isidoro Dias Lopes, onde corre a céu aberto, mas isolado do acesso público por gradil, como vemos na figura 55.

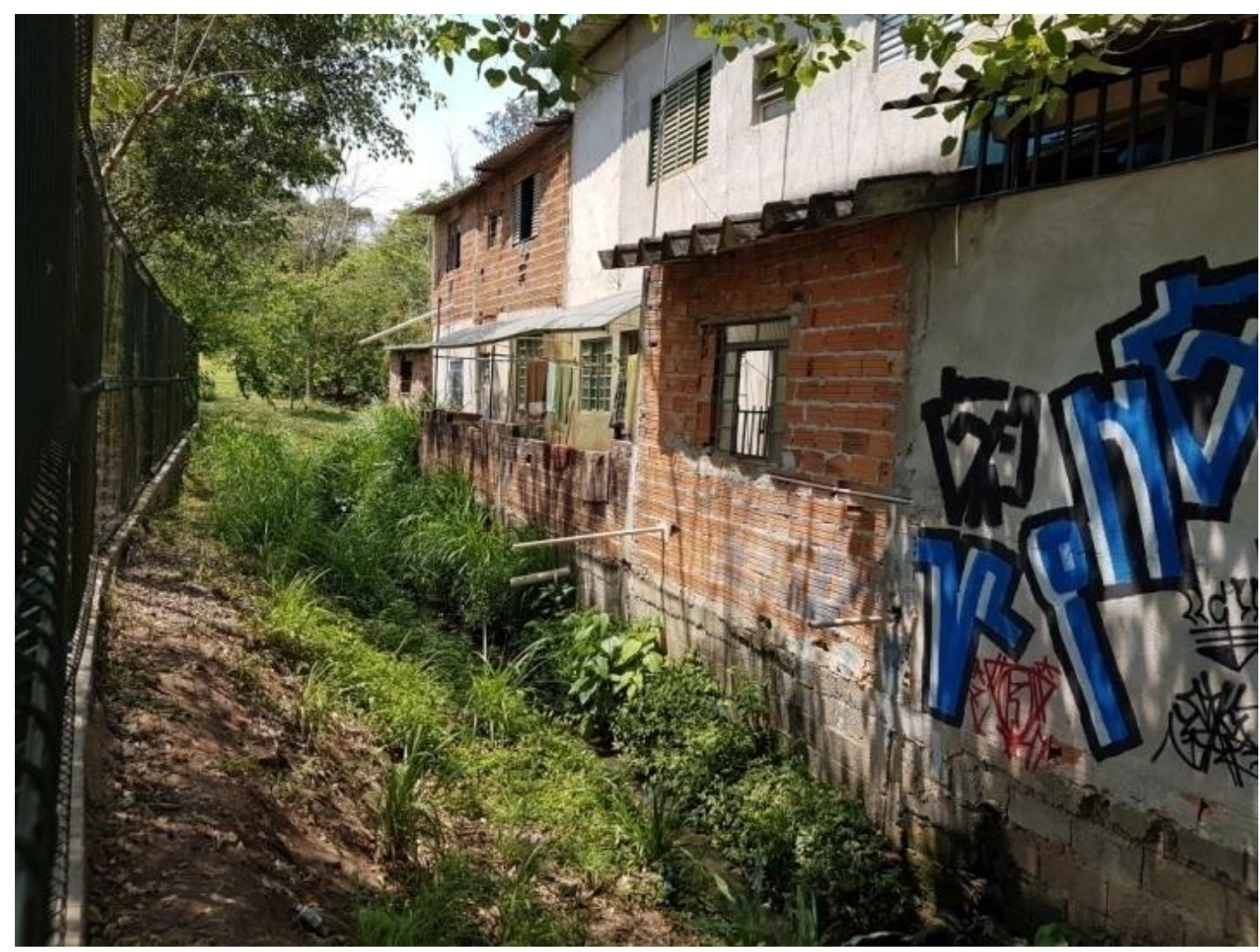

Figura 55. Córrego do índio correndo a céu aberto, mas isolado por grade do contato com os usuários do Parque do Horto Florestal. Foto: Evy Hannes, 2016.

O acesso a esse núcleo de lazer do parque está sobre a confluência do córrego Peri, parcialmente canalizado, com o córrego do Índio. A partir desse ponto segue a céu aberto, em canal de concreto mal acabado, apertado entre construções irregularmente construídas em suas margens de proteção e recebendo descarte de esgoto dessas, como 
mostra a figura 56, por cerca de $300 \mathrm{~m}$. Em seguida, por cerca de mais $350 \mathrm{~m}$, corre em calha de terra (como mostra a figura 57) até a Praça Helvécio Gomes Oliveira, sua confluência com o córrego Guaraú, que nesse trecho corre também a céu aberto desde a estação de tratamento de água do Guaraú.

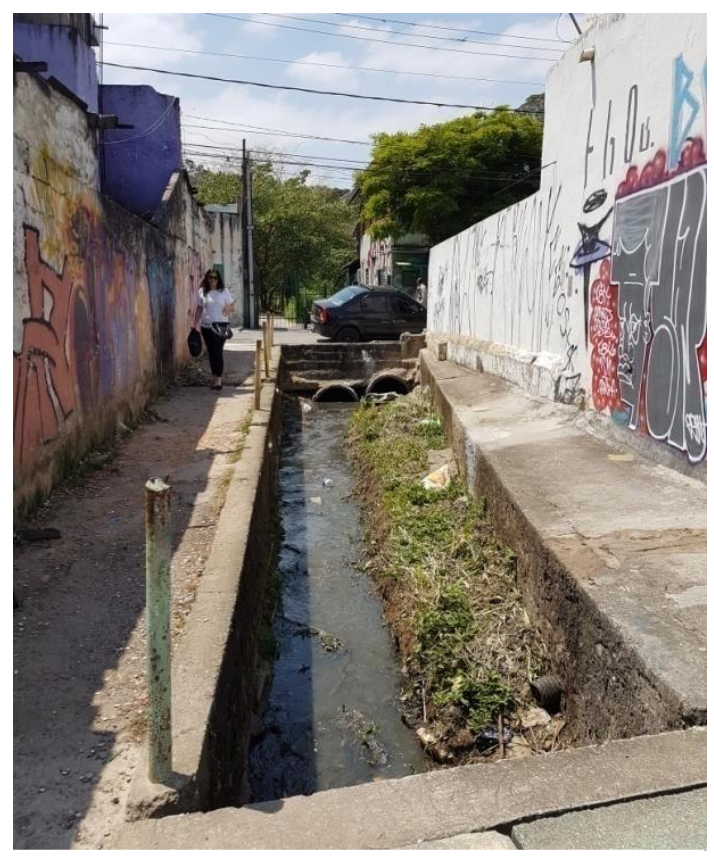

Figura 56. Córrego do índio correndo em calha de concreto em viela entre residências. Foto: Evy Hannes, 2016.

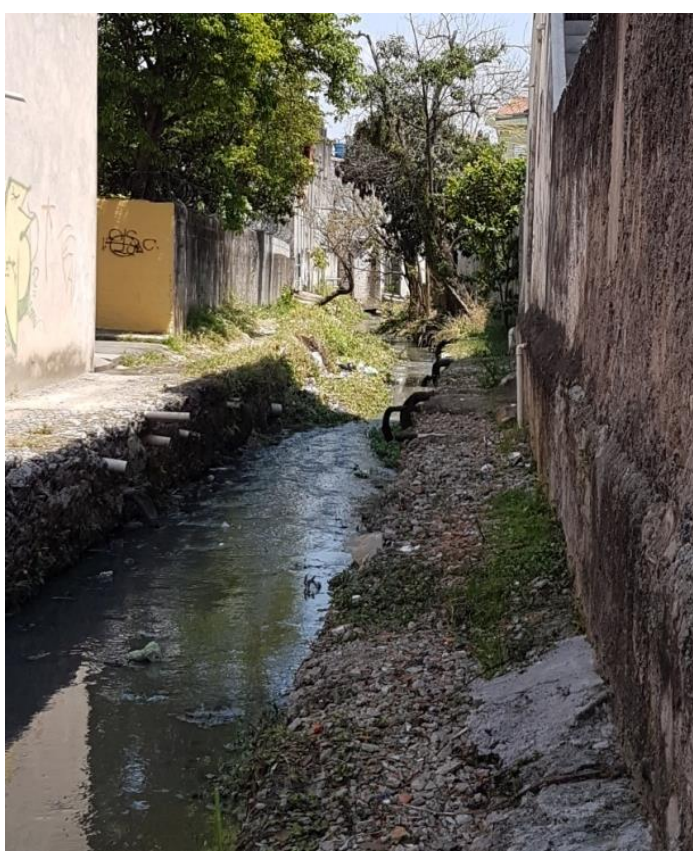

Figura 57. Córrego do índio correndo em calha de terra, não natural, entre residências. Foto: Evy Hannes, 2016.

Não se tem acesso público à suas nascentes que estão em meio à vegetação do parque. Das duas que estão localizadas fora do parque, uma delas possivelmente se encontra sob conjunto de edifícios residenciais construídos nas esquinas das Ruas Said Saad e Torre da Alfândega, como é possível observar na imagem 58 e onde nota-se saída constantemente de água, através de tubos no muro do edifício, que é descartada no passeio e escorre pela sarjeta, como mostra a imagem 08. A imagem 58 mostra carta do Geosampa com cursos d'água originais e topografia em formato de anfiteatro, reforçando a hipótese da localização da nascente nesse ponto. A imagem 59 mostra as patologias e marcas de 
infiltração e umidade nos muros recém construídos da obra, indicando a presença de água em seu interior.

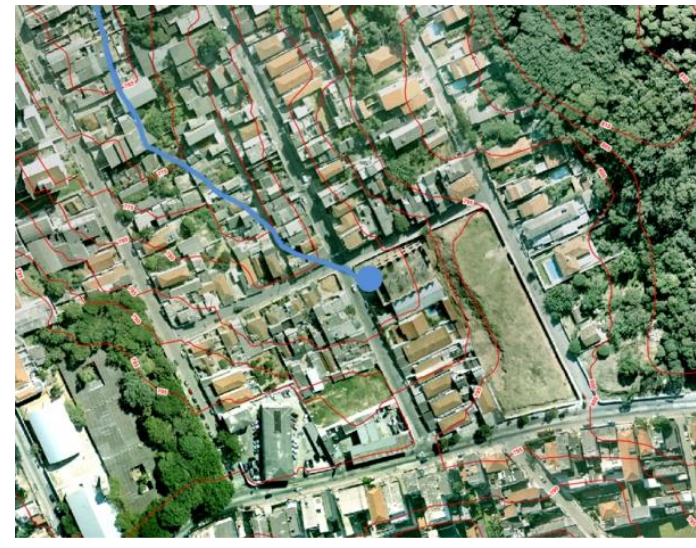

Figura 58. Possível localização de nascente na esquina das Ruas Torre da Alfândega e Said Saad. Foto: Trabalho da autora sobre imagem Geosampa, 2017.

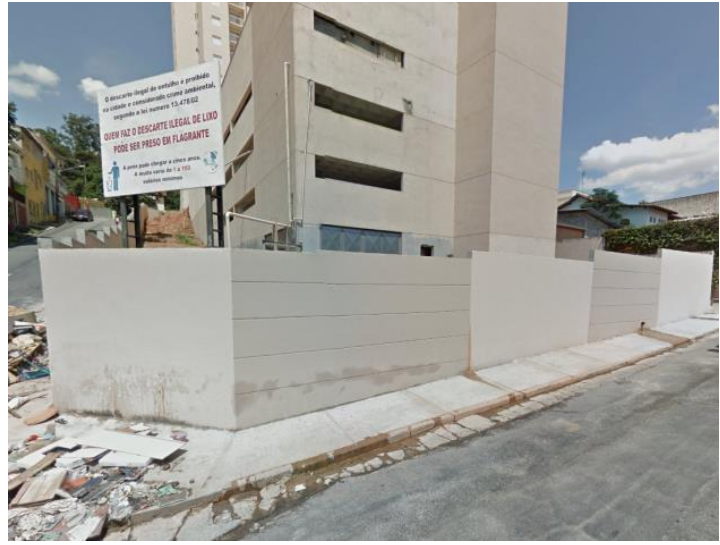

Figura 59. Marcas de infiltração nos muros do edifício e água corrente no passeio na esquina das Ruas Torre da Alfândega e Said Saad. Foto: Google street view, 2015.

A outra nascente localizada externamente aos muros do Parque do Horto Florestal está provavelmente localizada em uma curva da Rua Dr. Alcides Cintra Bueno Filho, como mostra marcação em círculo azul sobre a imagem dos cursos d'água do Geosampa, imagem 60. A topografia em anfiteatro também confirma a hipótese. A figura 61 mostra foto do local.

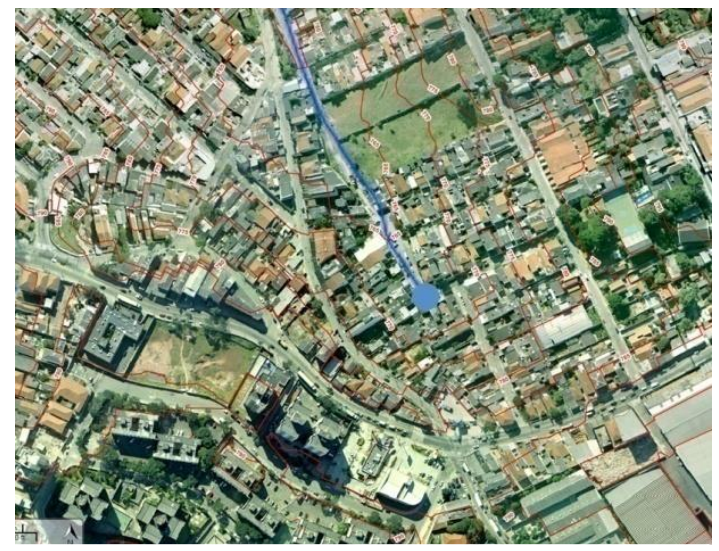

Figura 60. Possível localização de nascente na curva da R. Dr. Alcides Cintra Bueno Filho. Foto: Trabalho da autora sobre imagem Geosampa, 2017.

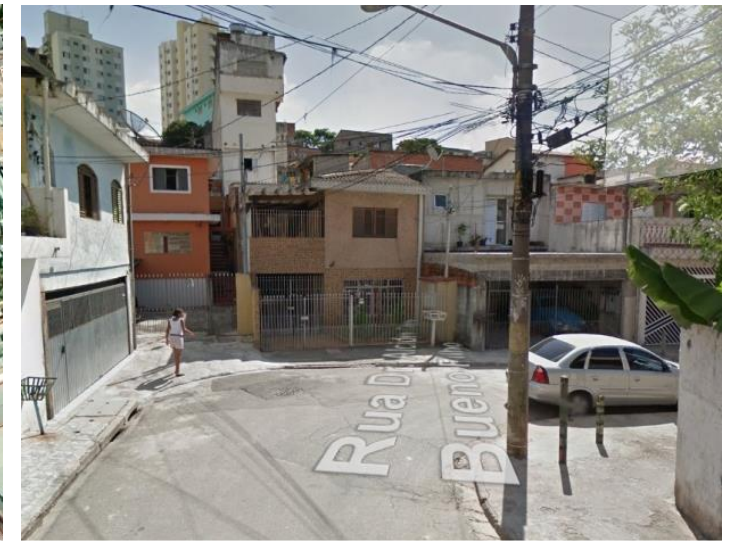

Figura 61. Foto da área da possível localização de nascente na curva da R. Dr. Alcides Cintra Bueno Filho. Foto: Google street view, 2015. 


\subsection{GEOMORFOLOGIA E COMPARTIMENTAÇÃO DA PAISAGEM}

O conceito que define a identificação de domínios morfológicos que apresentam semelhantes formas de relevo e topografia, oriundas de processos de evolução diferenciados, é conhecido como compartimentação topográfica. (Ab'Saber, 1969). Para compor esses compartimentos deve-se também estudar o tipo de vegetação presente no mesmo. Tais formações de relevo são importantes, pois refletem a organização sistêmica formadora da paisagem e que orienta suas principais dinâmicas, além de influenciar a ecologia local. (SCHUTZER, 2012b).

Com base na observação da topografia e mapas geomorfológicos da área analisada, podem-se perceber quatro tipos de compartimentos de relevo na área estudada: outeiros, colinas e espigões secundários; encostas e vertentes das colinas e outeiros; anfiteatros e nascentes; e planícies aluviais, como mostra a figura 63 abaixo.

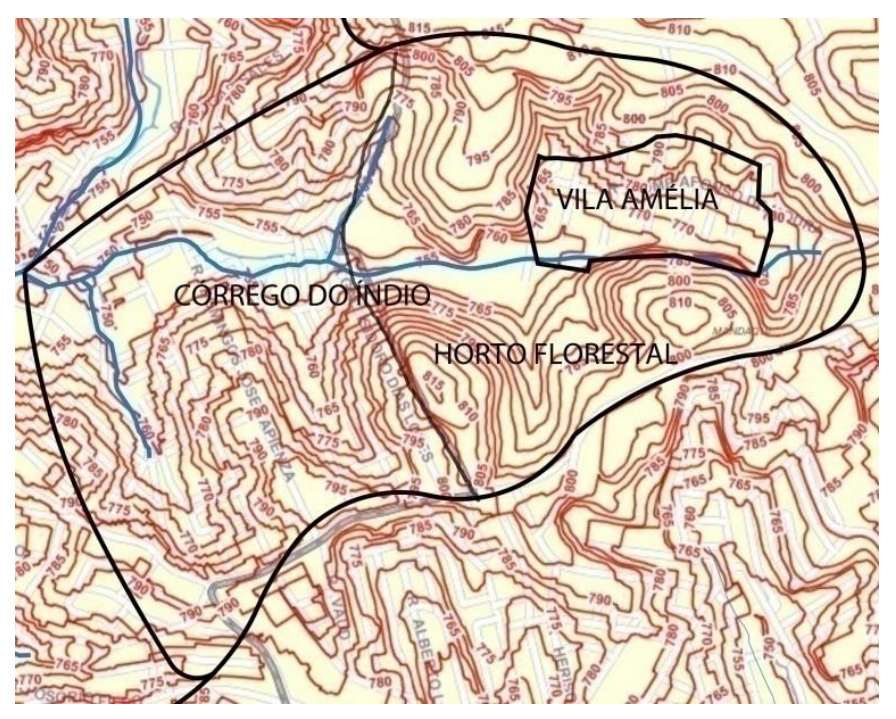

Figura 63. Mapa da topografia da bacia hidrográfica do córrego do Índio. Trabalho da autora sobre imagem Geosampa.

O relevo ao redor da planície aluvial do índio é constituído de outeiros, colinas e pequenos espigões secundários de topo aplainados, vinculados à Cantareira e fazendo limite com o compartimento da serra de mesmo nome, como vemos na figura 63. Enquanto a cota média do 
curso do córrego está por volta de $750 \mathrm{~m}$, os outeiros tem elevação por volta de 785 a 820, sendo esta última cota do espigão secundário, que acompanha a Rua Alto do Sucuriu e é o divisor de águas da bacia do Índio e do córrego Bispo. Na margem esquerda do córrego o divisor de águas fica por conta do espigão secundário por onde passa a Rua Vinte e Oito de Janeiro, que se junta à Av. Parada Pinto, em cota entorno de $785 \mathrm{~m}$, sendo este o divisor entre o córrego do Índio, Água Preta e a bacia do Lauzane, já no Distrito do Mandaqui.

O topo aplainado dos outeiros e espigões secundários favorece a infiltração superficial, que deve ser incentivada a fim de regular o ciclo hidrológico de infiltração e filtragem das águas. Sendo áreas livres de inundações, favorecem $\circ$ assentamento urbano. Tais características confirmam o histórico de ocupação da Zona Norte de São Paulo, que começou pelo topo dessas elevações.

As encostas e vertentes das colinas e outeiros são áreas de declividade média entre 5 a 25\%, com trechos mais íngremes que chegam a $60 \%$ de inclinação, como mostra a figura 64 . Nessas áreas o processo de escoamento superficial é predominante e, portanto, áreas com possibilidade de erosão e deslizamentos quando desprovidas de vegetação ou quando não apresentam elementos de drenagem adequada. (SCHUTZER, 2012). Suas cotas variam entre 820, no topo dos outeiros mais altos a 740, nas partes mais baixas da planície aluvial. São áreas densamente ocupadas, algumas dessas irregularmente, com construções precárias que correm risco de desmoronamento e deslizamento em épocas de chuvas fortes.

É nas encostas mais suaves da área, próximo às nascentes primárias, até o limite da planície aluvial que está localizado o bairro da Vila Amélia. Apresenta declividade padrão de 5 a $25 \%$, variando entre as cotas $760 \mathrm{~m}$ e $790 \mathrm{~m}$, como mostra a figura 65, estando à ocupação limitada por cursos d'água. 


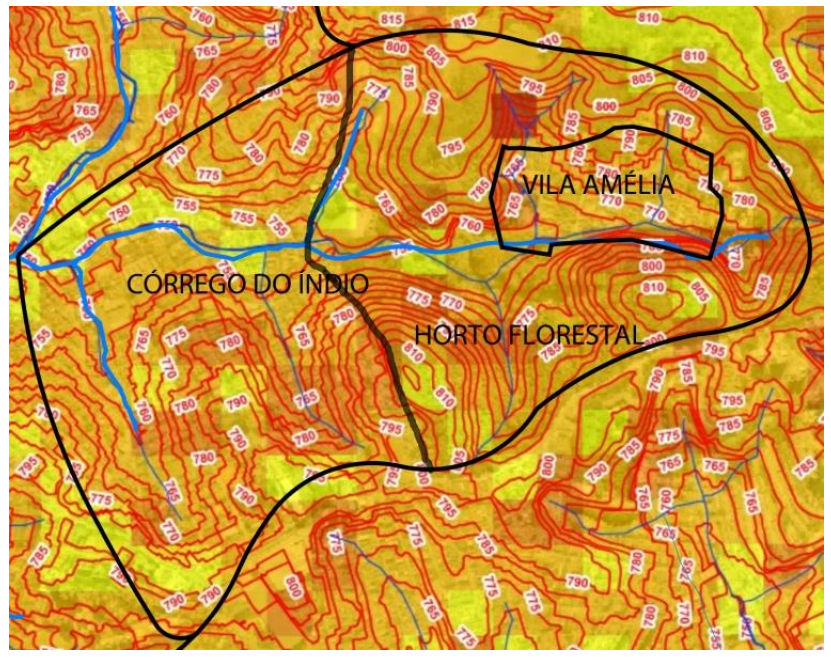

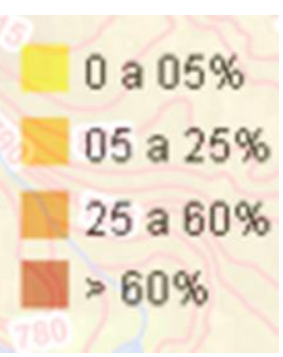

Figura 64. Mapa da topografia mostrando as declividades da bacia hidrográfica do córrego do Índio. Trabalho da autora sobre imagem Geosampa.

As encostas das colinas da área conformam os anfiteatros onde estão as nascentes que formam a bacia hidrográfica do córrego do Índio, algumas delas já suprimidas pela urbanização. Como colocado por Schutzer (2012), "são espaços de natureza por excelência", onde predomina o escoamento superficial, há possibilidades de erosão e deslizamentos e onde a umidade natural deve ser preservada com a manutenção de densa vegetação nos anfiteatros naturais.

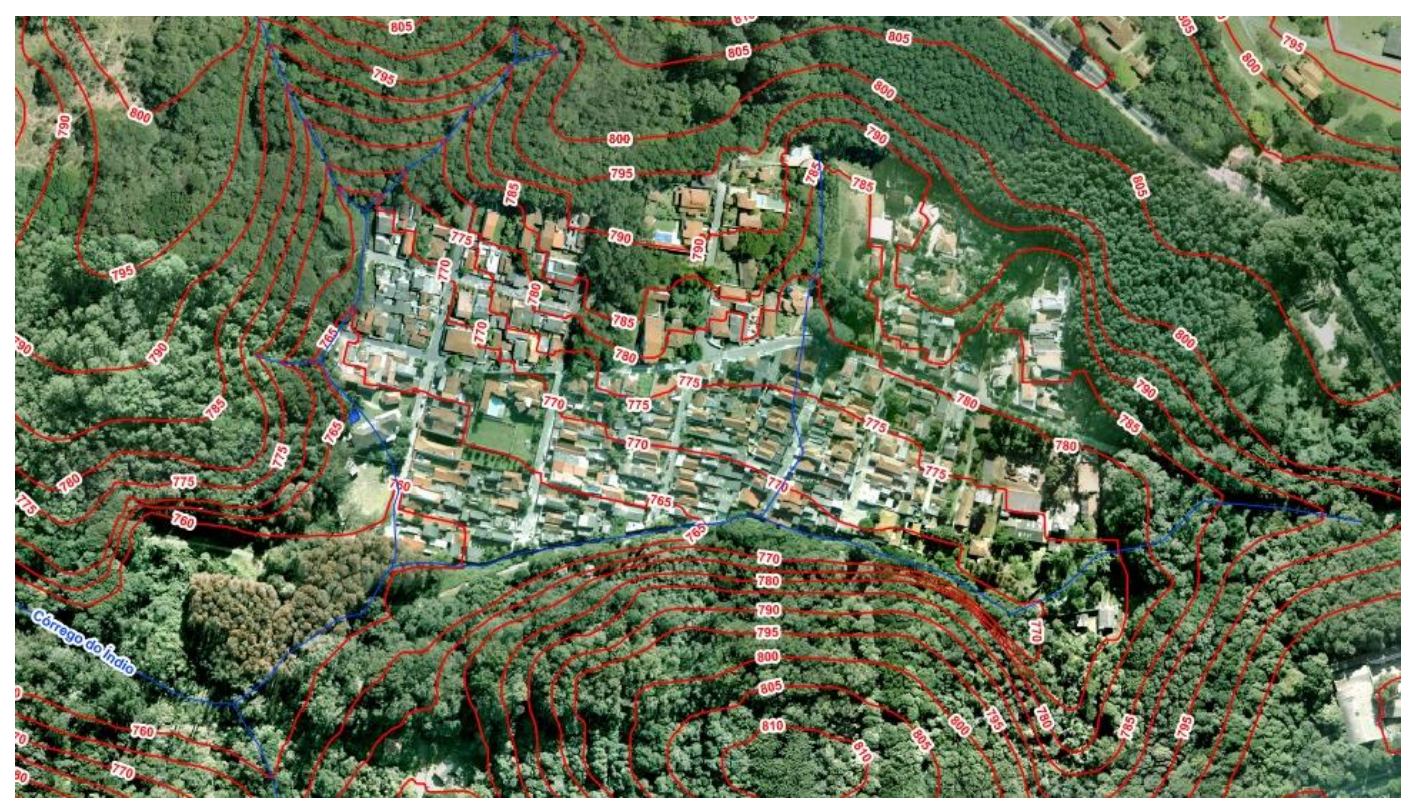

Figura 65. Mapa mostrando a Vila Amélia inserida em meio à vegetação do Horto Florestal, sua topografia, cursos d'água e linhas de drenagem. Trabalho da autora sobre imagem Geosampa. 
As planícies aluviais ou várzeas são as áreas mais baixas e aplainadas, com cotas entre 765 e 740, que recebem as águas da bacia e com elas seus sedimentos, tendo solo úmido e lençol freático superficial, o que restringe sua capacidade de infiltração. São áreas muito sensíveis que devem ser preservadas para o armazenamento de águas nas épocas de cheias e onde a ocupação deve ser evitada. Também constituem áreas de "natureza por excelência" que devem ser ocupadas por parques e densa arborização. (SCHUTZER, 2012).

\subsection{ESTRUTURA SUPERFICIAL}

A estrutura superficial da paisagem, também chamada de epiderme, corresponde à camada superficial do solo, onde os processos geomorfológicos atuam, reconhecendo os tipos de solo que a compõe e suas características, bem como sua dinâmica em relação aos processos naturais e humanos, mostrando sua potencialidade de armazenamento e infiltração de água e estabilidade às atividades humanas. Sua análise tem como resultado informações importantes sobre a capacidade do solo como suporte físico para intervenções urbanas, sua potencialidade como recurso, como por exemplo, qualidade do solo para uso agrícola ou abastecimento de água, e também sua potencialidade como ambiente de preservação. Sua análise deve incluir as transformações produzidas pelo homem, principalmente nas áreas urbanizadas, onde o solo se encontra bastante alterado, já quase não apresentando sua composição natural. (SCHUTZER, 2012).

A região onde se localiza a bacia hidrográfica do córrego do Índio é composta por duas principais formações geológicas: no vale principal do córrego do Índio, não incluindo a sub-bacia do Guaraú, o solo é constituído por areias, argilas e conglomerados de espessura média da planície ou cobertura aluvial e coluvial quaternária; nas demais áreas, é 
formado pelas unidades magmáticas e metamórficas e sua composição é majoritariamente granítica, como mostra a figura 66. (AB'SABER, 2007).

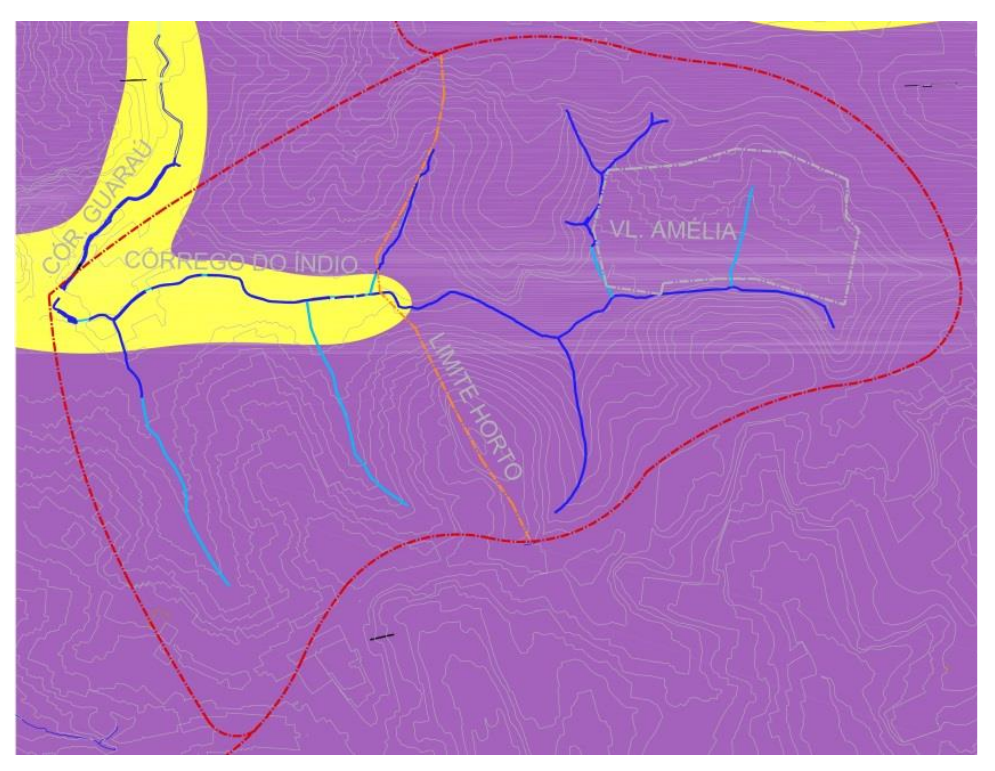

Figura 66. Mapa de composição geológica onde a linha tracejada vermelha representa a bacia hidrográfica do córrego do Índio, a linha tracejada laranja mostra 0 limite do Horto Florestal, a linha tracejada cinza mostra a Vila Amélia, o amarelo representa a cobertura aluvial e coluvial quaternária de areias e argilas e o roxo - embasamento précambriano de unidades magmáticas $e$ metamórficas. Trabalho da autora sobre imagem Atlas Ambiental.

A seção geomorfológica da Serra da Cantareira e Rio Tietê (figura 67), desenvolvida por Aziz Ab'Saber, mostra a formação do solo das baixas colinas e outeiros dos bairros entre a Serra da Cantareira e a planície do rio Tietê, com seu embasamento em granito e camadas mais superficiais em areia, argila e cascalhos.

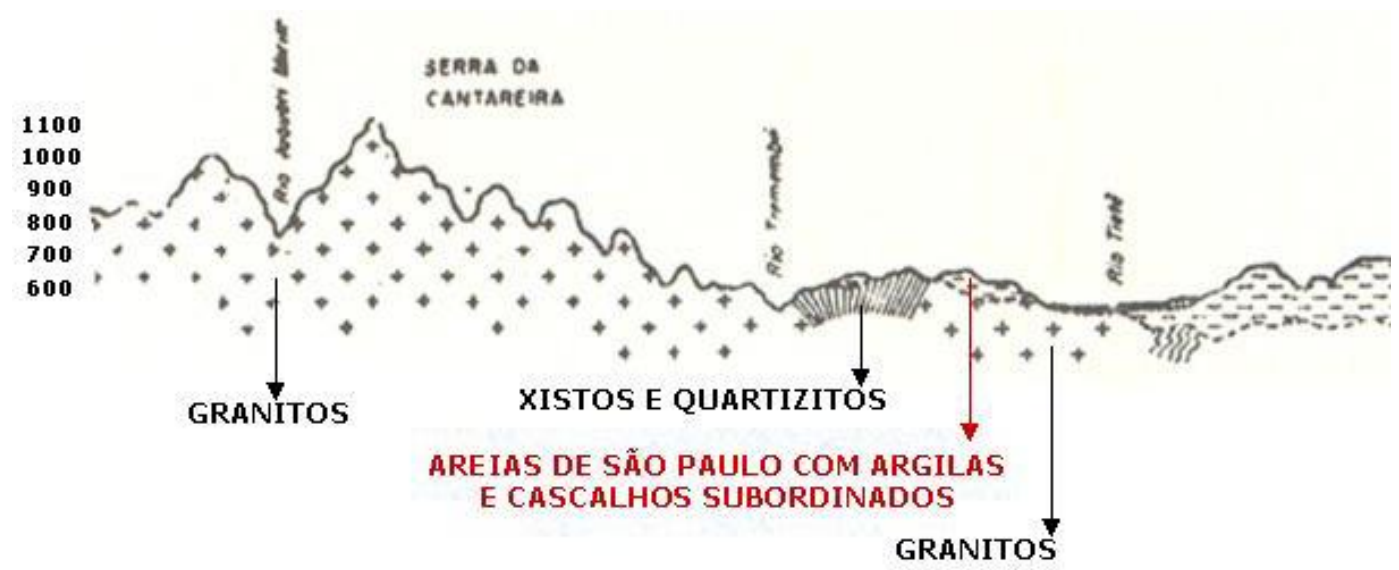

Figura 67. Seção geomorfológica da Serra da Cantareira mostrando a composição de seus solos. Trabalho da autora sobre imagem Aziz Ab'Saber, 2007. 
As planícies aluviais, como a do canal principal do Índio, apresentam como características derivadas de sua geomorfologia, lençol freático raso, solos moles e áreas suscetíveis a inundações. Em seu estado natural, os cursos d'água corriam nas planícies formando meandros alternantes, como mostra a figura 68. São áreas que não apresentam condições propicias à ocupação ou urbanização e que deveriam ser resguardadas a fim de se preservar suas funções ambientais como umidificadoras do ambiente e também como reservas de biodiversidade. (SCHUTZER, 2012, AB'SABER, 2007). Hoje, com a área ocupada pela urbanização, já não se vê mais os meandros naturais dos córregos e percebe-se o agravamento dos problemas de enchentes devido à impermeabilização excessiva do solo e a ocupação das áreas de suas várzeas.

As áreas de composição granítica apresentam como característica baixa capacidade de drenagem e solo profundo firme, constituído pelo maciço cristalino da Cantareira. (SCHUTZER, 2012, AB'SABER, 2007). Os problemas em relação à drenagem se acentuam nos locais onde as encostas são íngremes e favorecem o aumento da velocidade de escoamento superficial, o risco de erosão e o carregamento de sedimentos para as partes baixas do relevo.

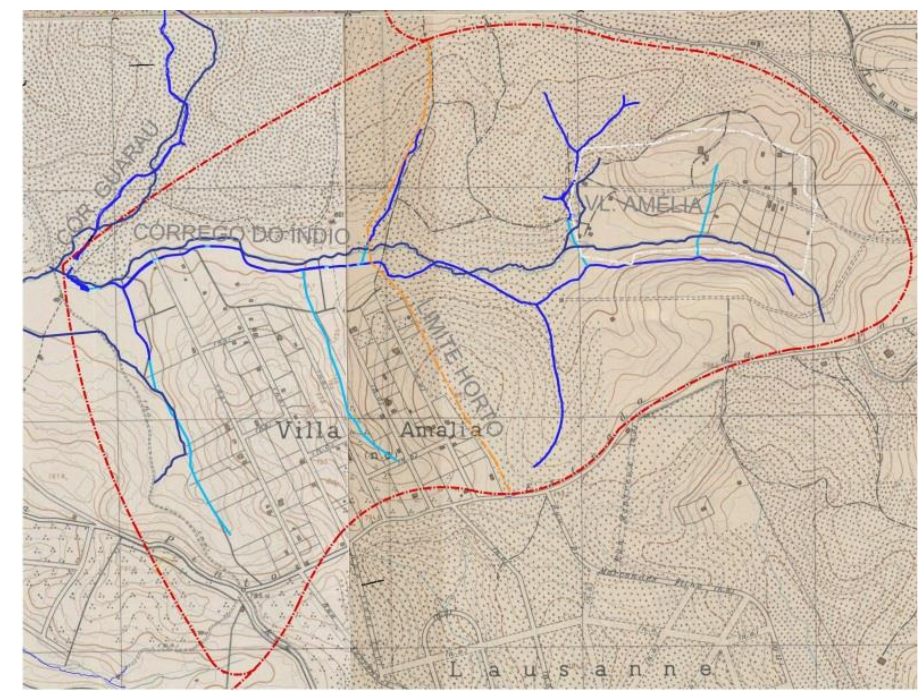

Figura 68. Mapa Sara Brasil onde a linha tracejada vermelha representa a bacia hidrográfica do córrego do Índio, a linha tracejada laranja mostra o limite do Horto Florestal, a linha tracejada cinza clara mostra a Vila Amélia, o azul escuro mostra os trajetos atuais das águas correndo a céu aberto, o azul claro os trajetos canalizados e o azul marinho os trajetos originais. Trabalho da autora sobre imagem Sara Brasil.. 
Por se tratar de topografia movimentada, a urbanização lança mão de inúmeros cortes e aterros sobre o relevo original, para torná-lo passível de ocupação. Esses pequenos lotes, muitas vezes irregulares e com construções precárias, são ainda mais suscetíveis aos perigos de deslizamentos, enquadrando-se, muitas vezes, em áreas de risco e extrema vulnerabilidade.

\subsection{FISIOLOGIA DA PAISAGEM}

A fisiologia da paisagem trata dos processos, metabolismos da paisagem, dos mecanismos que interagem para seu funcionamento. (SCHUTZER, 2012; AB'SABER, 1969). Trata das dinâmicas hídricas e climáticas, bem como das ações antrópicas que influenciam na formação e processos da paisagem, transformando-a e alterando seus ciclos.

As dinâmicas climáticas são alteradas pela urbanização, podendo criar situações de desconforto ambiental e até risco à saúde humana. Fileiras de edifícios criam túneis de vento e sombra excessiva, o excesso de construção aumenta a temperatura, a ausência de vegetação diminui a umidade relativa do ar. Os gases emitidos pelos veículos poluem o ar, comprometendo a saúde dos moradores da cidade. Morros altos barram a circulação de ar, criam inversões térmicas, áreas de várzeas umidificam o ar e contribuem para o crescimento e saúde da vegetação. (SCHUTZER, 2012; SPIRN, 1984).

Em relação às unidades climáticas urbanas, caracterizadas por microclimas específicos originados devido aos impactos que a urbanização causa sobre as dinâmicas do território, a bacia do córrego do Índio compreende 03 unidades: a unidade urbana periférica residencial baixo-favelas, a unidade urbana climática periférica da Zona Norte Parque da Cantareira e a unidade climática urbana central residencial baixo do Limão-Casa Verde, como ilustra a figura 69. As duas primeiras tem alto índice pluviométrico, por volta de 1400 a $1450 \mathrm{~mm}$ ano, e 
recebem ainda as águas escoadas da Serra da Cantareira, o que as caracteriza como áreas com grande potencial de inundações. Esse alto índice de pluviosidade, associado à declividade topográfica, acentua o risco de deslizamentos, colocando em estado de risco principalmente as áreas ocupadas por favelas, que tem construções mais simples. A região localizada na unidade climática da Zona Norte - Parque da Cantareira corresponde diretamente ao bairro da Vila Amélia e ao Horto Florestal, apresentando situação climática privilegiada, devido a estar localizada em altitude mais elevada e em meio à relevante cobertura vegetal. (ATLAS AMBIENTAL DE SÃO PAULO, 2000).

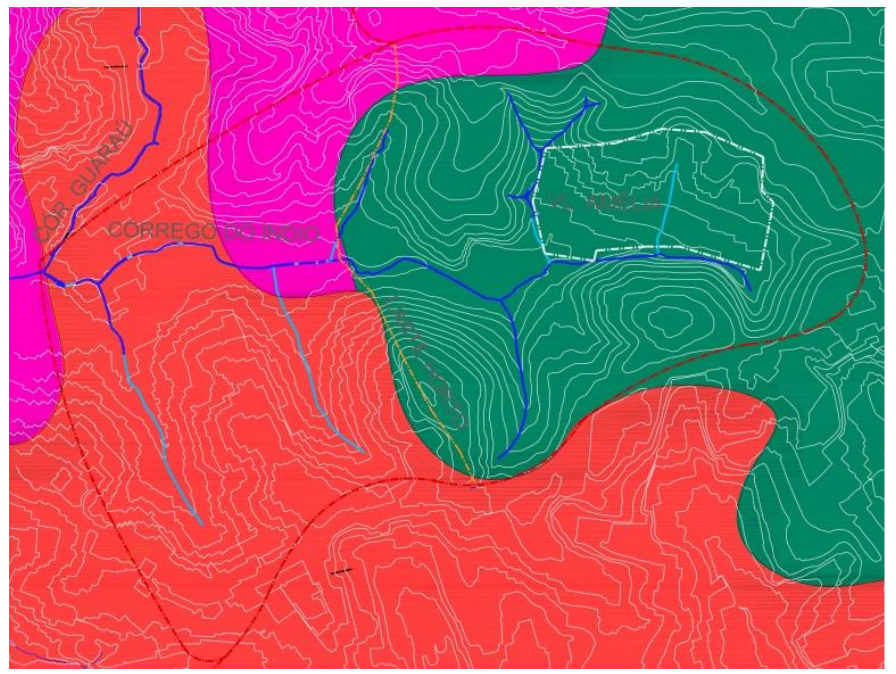

Figura 69. Mapa mostrando a bacia do córrego índio e suas unidades climáticas urbanas onde o vermelho representa a Unidade climática urbana central além Tietê: residencial baixo Limão-Casa verde; o rosa representa a Unidade climática urbana periférica da zona norte: residencial baixo-favelas; e a verde representa a Unidade climática urbana periférica da zona norte: Cantareira. Trabalho da autora sobre imagem do Atlas Ambiental.

Considerando os dados do mapa das llhas de Calor do Atlas Ambiental da Cidade de São Paulo, a área onde está localizada a bacia do córrego do Índio abrange dois espectros de cor da escala de temperatura variando de $29,5^{\circ} \mathrm{C}$ a $30^{\circ} \mathrm{C}$, quarta e quinta maiores na escala, deixando clara a influência da urbanização e falta de arborização na temperatura. Quando adentra os limites do Horto Florestal as temperaturas caem cerca de $1^{\circ} \mathrm{C}$, ficando entorno de $28.5^{\circ} \mathrm{C}$ no bairro da Vila Amélia e diminuindo mais alguns graus em direção à região da Cantareira, devido à presença da vegetação densa da área. (figura 70). 


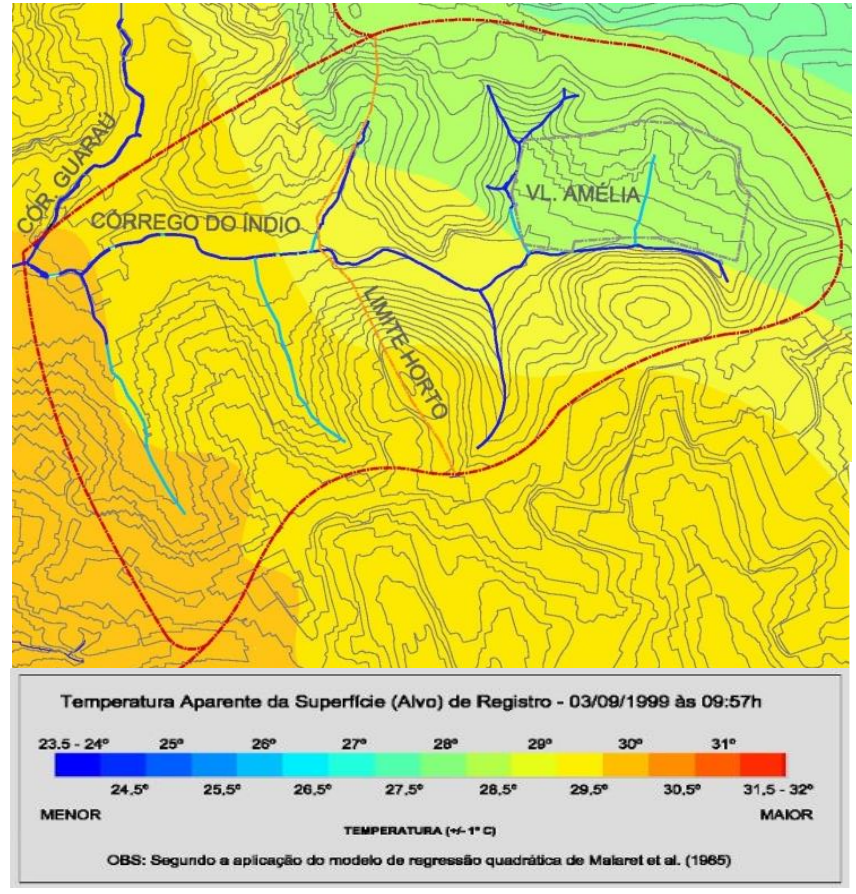

Figura 70. Mapa das llhas de Calor onde a linha tracejada vermelha representa a bacia hidrográfica do córrego do Índio, a linha tracejada laranja mostra o limite do Horto Florestal, a linha tracejada cinza clara mostra a Vila Amélia. Trabalho da autora sobre imagem do Atlas Ambiental.

A bacia do córrego Cabuçu de Baixo, onde está inserida a subbacia do córrego do Índio, tem como divisor de águas os altos da Serra da Cantareira, que é o principal divisor de águas da Bacia do Alto Tietê, ao norte. A Cantareira desempenha papel de "moderador climático", devido à forte presença de água e cobertura vegetal que possui. Sua altitude interfere na circulação de ar, aumentando a quantidade de chuvas e baixando a temperatura local. (SCHUTZER, 2012).

Em relação à hidrodinâmica, o processo de urbanização gerou diversos impactos sobre ás águas da cidade, como a canalização de córregos, supressão de nascentes e ocupação das várzeas. Estes, somados à impermeabilização do solo e à ocupação irregular das margens dos cursos d'água, geraram graves problemas de poluição e enchentes na cidade de São Paulo. Segundo o Atlas Ambiental (2000), o principal ponto de alagamento da bacia do Índio está na confluência dos córregos do Índio e Guaraú, entorno da Praça Helvécio Gomes Oliveira.

Esses alagamentos são fruto da impermeabilização excessiva do solo, da ocupação urbana das áreas de várzea dos córregos e da topografia de colinas ao redor do mesmo que favorece o escoamento 
superficial, que traz consigo resíduos dos processos erosivos das encostas ainda nuas, além da poluição e lixo que se espalham pelas ruas, depositando-os no fundo dos cursos d'água e aumentando o assoreamento destes. Essas águas não conseguem infiltrar e recarregar o lençol freático e também não são armazenadas para outros usos, não colaborando com o ciclo hidrológico local e também agravando os problemas de seca no inverno. Esse processo é agravado já que, devido à ausência de vegetação, a evapotranspiração é muito pequena, o que também diminui a umidade relativa do ar, prejudicando a qualidade ambiental urbana e a saúde humana. Maior infiltração significa maior recarga dos aquíferos e maior surgimento de nascentes, com maior quantidade de água nessas. O processo de infiltração também colabora com a filtragem das águas que vão para o subsolo. (SCHUTZER, 2012; MASCARÓ, 2002).

\subsection{ZONEAMENTO AMBIENTAL: POTENCIALIDADES NATURAIS E} FUNÇÕES AMBIENTAIS NA BACIA DO CÓRREGO DO ÍNDIO

Schutzer (2012) coloca o zoneamento ambiental como o método de leitura do suporte físico e do meio construído que considera suas potencialidades naturais, seus processos e sua capacidade de suporte, em uma tentativa de criar zonas com diretrizes específicas de ocupação que respeitem as dinâmicas dos processos ecológicos e urbanos que as compõe. Tais diretrizes são criadas com base nas características observadas através da análise dos compartimentos do relevo, de sua estrutura superficial e da fisiologia da paisagem.

O produto do zoneamento ambiental é uma carta que mostra as unidades de paisagem resultantes das interações dos fatores citados anteriormente, ressaltando potencialidades e condicionantes de cada unidade, como mostra a figura 71. Essa carta mostra áreas de incentivo à 
percolação, infiltração e filtragem, ao armazenamento de água, à indução de evaporação, indução de evapotranspiração e redução de emissividade de calor. Marca também áreas com restrição ao escoamento superficial, à infiltração, não favoráveis à filtragem, bloqueio de ventos, comportamento do solo, instalação de atividades poluidoras de ventos e do lençol freático. (SCHUTZER, 2012).

O compartimento dos outeiros, colinas e pequenos espigões secundários, com seus topos aplainados, devem incentivar a permeabilidade do solo para que o processo de infiltração possa abastecer o lençol freático e as nascentes. Tal processo também vai combater a super impermeabilização do solo que acarretaria no aumento do escoamento superficial para as encostas, levando sedimento e poluição aos cursos d'água e provocando erosão. Por estarem em cotas mais altas, apresentam boa circulação de ventos, que favorecem a dispersão de poluentes e a refrigeração do ar. O plantio de árvores ajudaria nesse processo de refrigeração e também de umidificação das áreas baixas através dos ventos.

As encostas, vertentes das colinas e outeiros têm processo de escoamento superficial predominante, podendo gerar erosão no solo e deslizamentos, carregando sedimentos para os cursos d'água e contribuindo com as enchentes. Devido a essas características, deve-se incentivar medidas de retenção e diminuição da velocidade do escoamento das águas. 


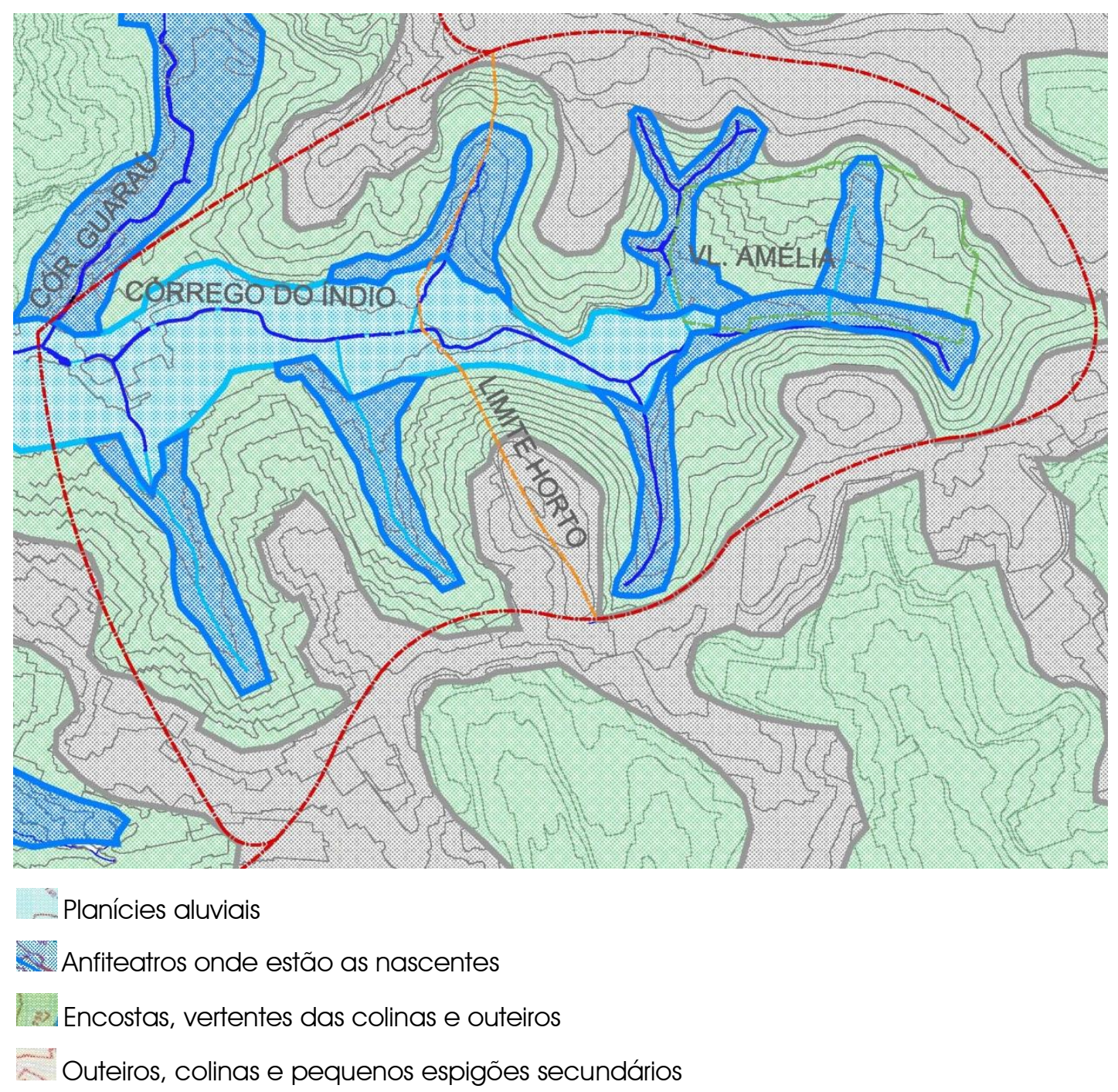

Figura 71. Mapa mostrando o zoneamento ambiental do córrego do Índio onde a linha tracejada vermelha representa a bacia hidrográfica do córrego do Índio, a linha tracejada laranja mostra o limite do Horto Florestal, a linha tracejada verde mostra a Vila Amélia. Trabalho da autora sobre imagem do Geosampa.

É nessa zona ambiental que se localiza a Vila Amélia. Apesar de estar em área onde não se incentiva a ocupação, devido ao risco de deslizamentos, apresenta inclinação até $25 \%$, o que ameniza a questão. O fato de o solo estar bastante impermeabilizado pela abertura de ruas agiliza o carregamento de poluentes e sujeira, que é levado para $O$ córrego pelas águas das chuvas. A ocupação da área não deve ser incentivada, pois se trata de uma ocupação em meio a uma mancha verde de valor ecológico importantíssimo para o município (ver figuras 72 e 73). Incentivar a ocupação vai gerar mais impactos e alterações ao 
funcionamento dos processos ecológicos como perda de habitat, aumento da área de borda, alteração das dinâmicas das populações e outros. Aconselha-se, nessa área, manter a ocupação existente propondo diretrizes de ecologia urbana e infraestrutura verde para amenizar os impactos já causados à área propondo, quando possível, a restauração do equilíbrio ecológico que vai levar à construção de uma ecocomunidade.

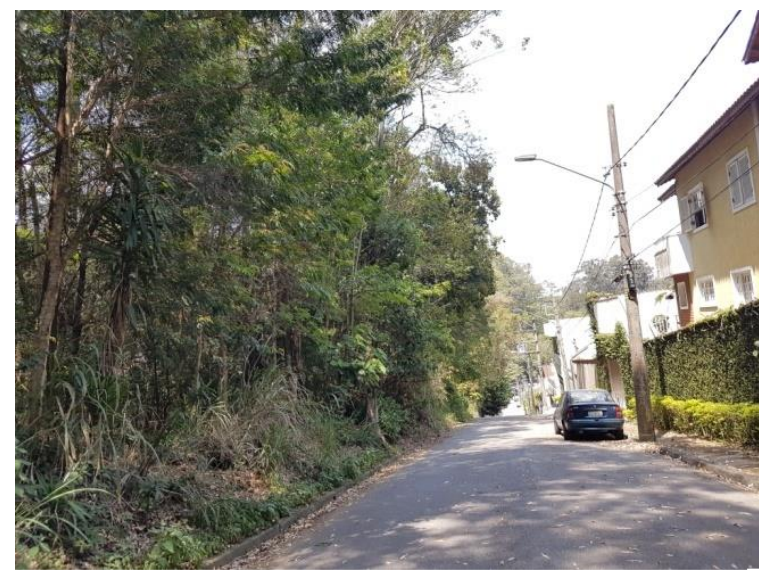

Figura 72. Foto de Rua na Vila Amélia que faz limite com a vegetação do Horto Florestal, nesse ponto com separação em tela metálica que permite a visualização da vegetação em todo seu extrato. Foto: Evy Hannes, 2016.

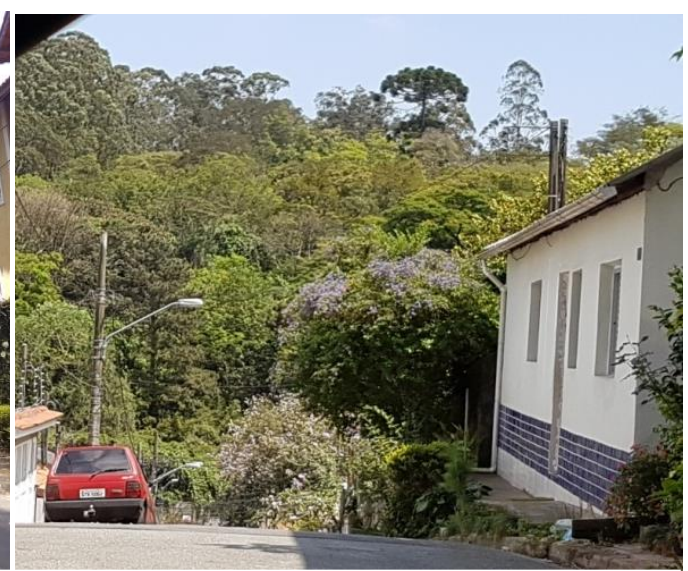

Figura 73. Foto de Rua na Vila Amélia mostrando o visual da vegetação do Horto Florestal ao fundo. Foto: Evy Hannes, 2016.

O compartimento das planícies aluviais ou várzeas, áreas mais baixas e aplainadas, tem como característica solos encharcados devido ao lençol freático que se contra entre 1 a $3 \mathrm{~m}$ de profundidade e que, portanto, não são favoráveis à infiltração. Como já dito anteriormente, são áreas sensíveis e que devem ser destinadas ao desenvolvimento de arborização intensa, criação de parques que utilizem a água como elemento principal, trabalhando sua reconexão com o homem e com a cidade. As wetlands são elementos de grande valor nessas unidades, já que trabalham filtrando resíduos e poluentes carregados pelo escoamento superficial, impedindo-os de poluir os cursos d'água. Bacias de contenção também devem ser incentivadas para ajudar a conter as cheias e evitar 
que as águas extravasem suas várzeas, atingindo as áreas urbanizadas e criando transtornos à vida urbana. Nessas áreas a ocupação não é incentivada, mas quando ela acontecer, deve ser de baixa densidade e de preferência em cotas destacadas do contato com o solo e áreas de transbordo.

Os anfiteatros onde estão as nascentes são áreas importantíssimas para o equilíbrio ecológico do ambiente urbano e devem ser preservadas, contemplando vegetação abundante. São áreas que apresentam escoamento predominante devido à sua alta declividade. A ocupação dessas áreas não deve ser incentivada. 


\section{CAPÍTULO 5}

\section{CARACTERIZAÇÃO MORFOLÓGICA E URBANA DA OCUPAÇÃO: A VILA AMÉLIA}

\subsection{HISTÓRICO DA OCUPAÇÃO}

A história do bairro da Vila Amélia remonta ao século XIX e hoje é envolvida em certa polêmica fundiária, originada devido a erros de documentação de suas terras. Com a desapropriação, em 1983, da Serra da Cantareira para construção do sistema de abastecimento da cidade, o Sítio do Cocho, antigo nome da Vila, ficou fora dos mapas e da documentação dessa desapropriação, pois foi confundido como sendo parte de outra propriedade. Na época, Eugênio Suplicy, dono das terras, não recebeu a indenização do Estado e só se deu conta do erro quando, por conta da implantação do Horto Florestal, teve suas terras contestadas e entrou com ação contra o Governo para reavê-las. Assim foi firmado um acordo entre o proprietário e o Estado, através de uma procuração, onde o Estado adquire parte das terras do Sítio do Cocho para formação do parque Alberto Lofgren. Em meio a essas terras estava a Vila Amélia, já ocupada por moradores que haviam legalmente comprado parte das terras de Suplicy. Esses moradores tem escritura de suas terras e lutam hoje para manter a vila e transformá-la em uma comunidade ecológica. O mapeamento de 1930 e 1943 mostra o loteamento da vila em meio à área do Horto Florestal, como mostram as figuras 74 e 75. Parte da área do parque estadual que circunda a Vila Amélia é conhecida como Arboreto da Vila Amália. 


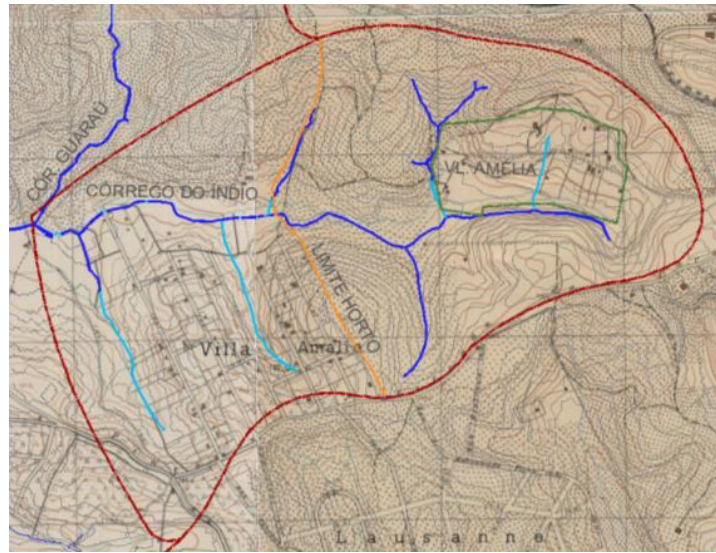

Figura 74. Imagem Sara Brasil de 1930 onde a linha tracejada vermelha representa a bacia hidrográfica do córrego do Índio, a linha tracejada laranja mostra o limite do Horto Florestal, a linha tracejada verde mostra a Vila Amélia. Trabalho da autora sobre imagem do Sara Brasil.

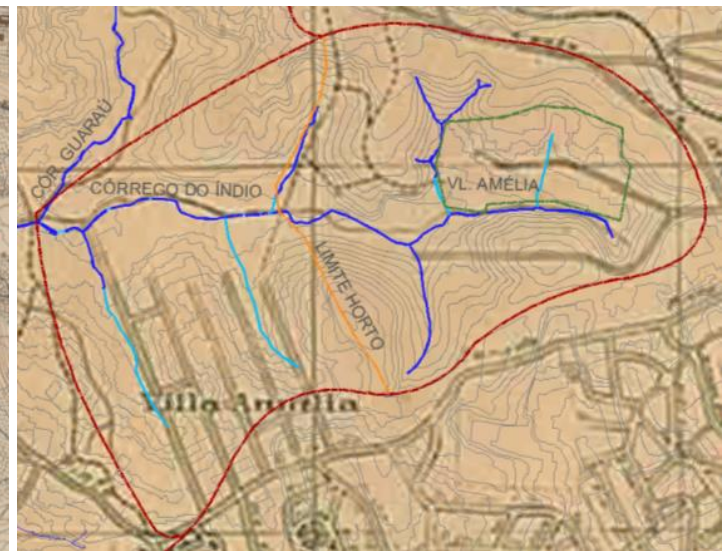

Figura 75. Imagem de 1943 onde a linha tracejada vermelha representa a bacia hidrográfica do córrego do Índio, a linha tracejada laranja mostra o limite do Horto Florestal, a linha tracejada verde mostra a Vila Amélia. Trabalho da autora sobre imagem de 1943.

Em 2010 os moradores construíram muros separando o bairro da mata do entorno, pois estavam sofrendo com assaltos, ficando o bairro, dessa forma, isolado e com único acesso pela Rua Tomé Afonso de Moura, travessa da Av. Santa Inês. Antes da construção desse muro e cercas havia uma trilha que ligava o bairro à Via Amália e ao Jd. Peri.

\subsection{USOS E OCUPAÇÃO TERRITORIAL}

De acordo com o Plano Diretor Estratégico da cidade de São Paulo (2014), a Vila Amélia e o Horto Florestal estão inseridos na Macrozona de Proteção e Recuperação Ambiental, como mostra a figura 76. Essa macrozona refere-se a áreas caracterizadas pela "existência de sistemas ambientais (...) em diferentes estágios de preservação e degradação ambiental" e prevê para ela diretrizes de preservação, conservação, recuperação, que respeitem sua fragilidade ambiental e garantam a manutenção de seus serviços ecossistêmicos, a promoção de atividades compatíveis com o desenvolvimento sustentável, a melhoria dos assentamentos, eliminação das situações de vulnerabilidade social e 
contenção da expansão urbana sobre áreas de interesse ambiental. (PDE, 2014).

O outro trecho da área referente à bacia hidrográfica do córrego do Índio, o bairro da Vila Amália, corresponde à Macrozona de Estruturação e Qualificação Urbana, mostrada em cinza no mapa da figura 76. Para essa área é prevista a convivência mais equilibrada entre componentes urbanos e ambientais, equilíbrio entre uso do solo e infraestrutura urbana, distribuição das ofertas de trabalho pelo território.

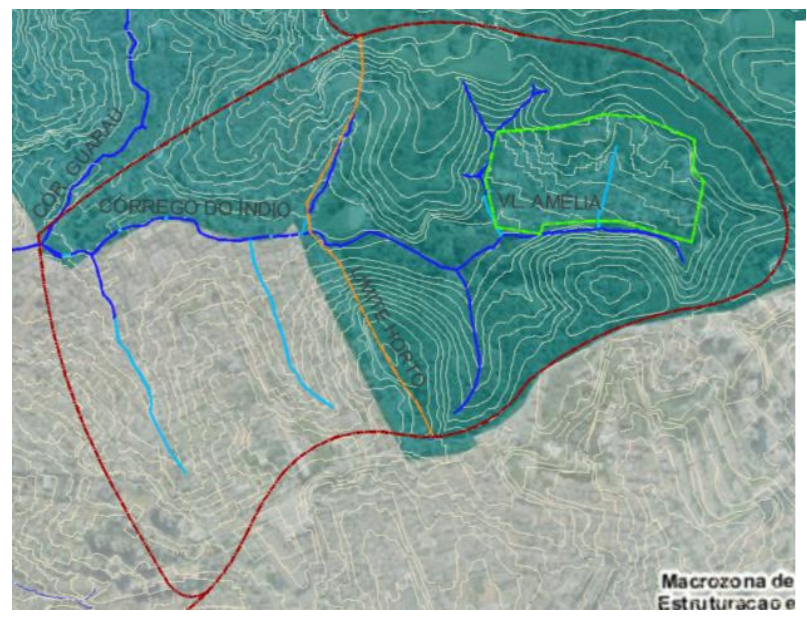

Figura 76. Mapa das Macrozonas do Plano Diretor da cidade de São Paulo onde a linha tracejada vermelha representa a bacia hidrográfica do córrego do Índio, a linha tracejada laranja mostra o limite do Horto Florestal, a linha tracejada verde clara mostra a Vila Amélia, a mancha verde escuro, a Macrozona de Proteção e Recuperação Ambiental e a mancha cinza a Macrozona de Estruturação e Qualificação Urbana. Fonte: trabalho da autora sobre imagem do Geosampa, 2017.

Já em relação às macroáreas, são três as que abrangem a área estudada. Horto Florestal e Vila Amélia estão na Macroárea de Controle e Qualificação Urbana e Ambiental, marcada em verde claro na figura 77. São áreas que ainda possuem vazios intraurbanos, padrão de ocupação predominantemente horizontal e áreas de reflorestamento. Nelas são previstas melhorias das questões ambientais, urbanização e regularização fundiária, contenção da expansão e do adensamento, construção de habitação de interesse social, melhoria do saneamento básico e incentivo à agricultura urbana.

Outras duas macroáreas se fazem presentes na área da bacia do córrego do Índio: a Macroárea de Redução da Vulnerabilidade Urbana e Recuperação Ambiental (amarelo claro na figura 77) e a Macroárea de Redução da Vulnerabilidade Urbana. Na primeira encontram-se muitos 
assentamentos irregulares de baixa renda e baixa qualidade ambiental, prevendo diretrizes de regularização fundiária, construção de habitação de interesse social, minimização dos problemas geológicos nas áreas de vulnerabilidade, proteção das áreas naturais e melhoria das condições de saneamento. Já a segunda macroárea é caracterizada por melhores condições de infraestrutura, como a questão do saneamento básico e apresenta diretrizes muito semelhantes às da área anterior.

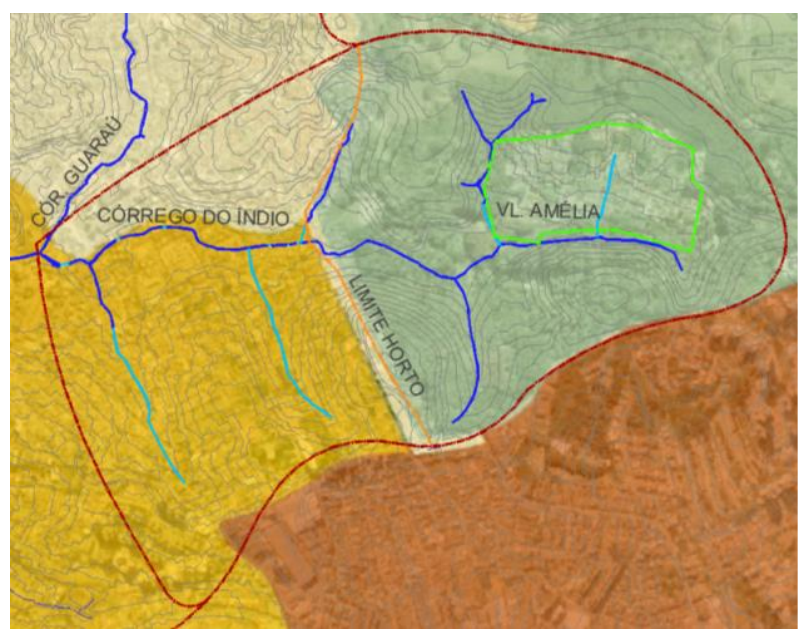

Figura 77. Mapa das Macroáreas do P. D.de São Paulo onde a linha tracejada vermelha representa a bacia hidrográfica do córrego do índio, a linha tracejada laranja mostra o limite do Horto Florestal, a linha tracejada verde claro mostra a Vila Amélia, a mancha amarelo claro, a Macroárea de Redução da Vulnerabilidade Urbana e Recuperação Ambiental, a mancha amarelo escuro a Macroárea de Redução da Vulnerabilidade Urbana e em verde claro a Macroárea de Controle e Qualificação Urbana e Ambiental. Fonte: trabalho da autora sobre imagem do Geosampa, 2017.

Em relação ao uso do solo, a área tem predomínio de ocupação residencial de baixa densidade, com residências de dois andares em sua maioria e de médio/baixo padrão, com alguns imóveis sendo classificados como alto padrão, como mostram as figuras 78 e 79. Apresenta núcleos de comércio e serviço na escala de atendimento às necessidades diárias do bairro, como ilustra a figura 80 . 


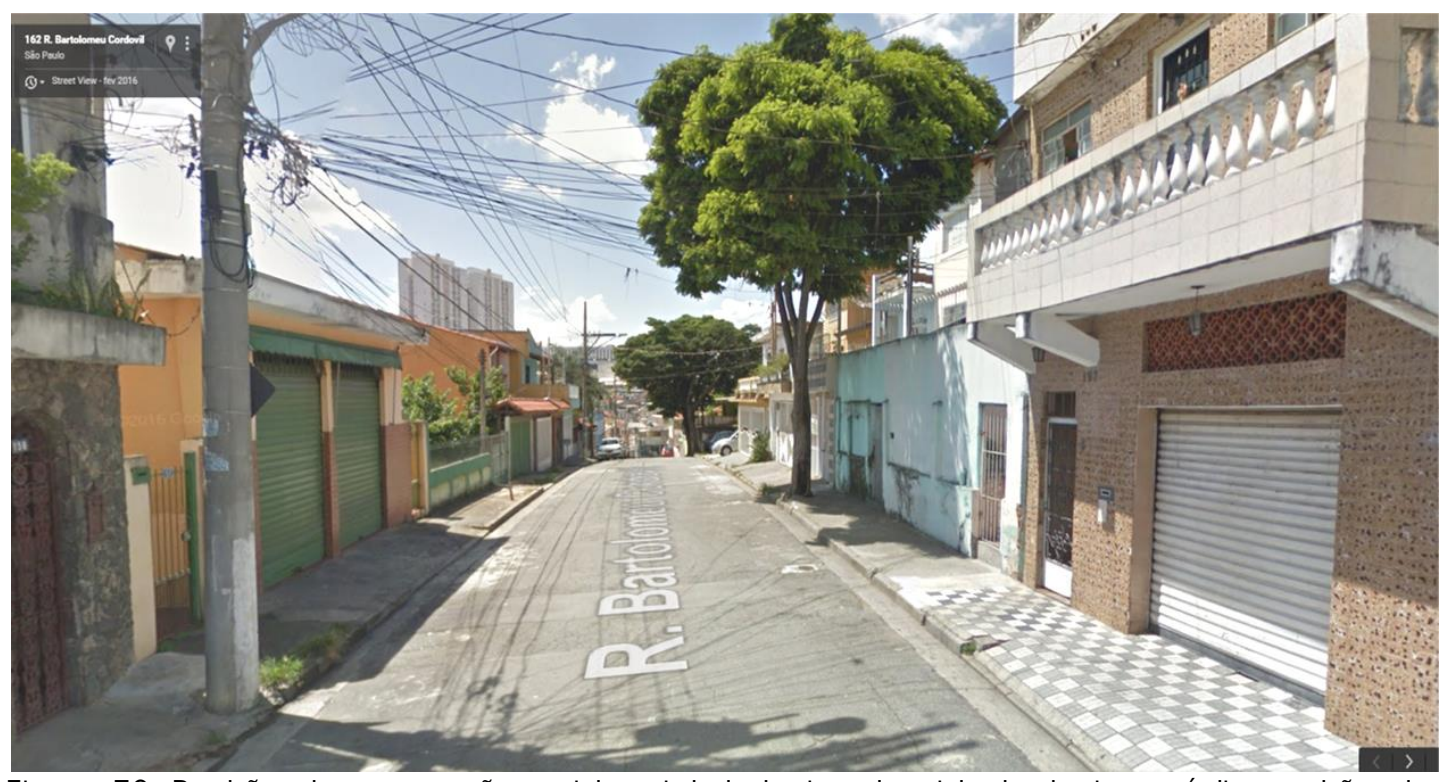

Figura 78. Padrão de ocupação residencial de baixa densidade, baixo-médio padrão da Vila Amália, bairro localizado na bacia do Índio e fora dos limites do Horto Florestal. Fonte: Google street view, 2016.

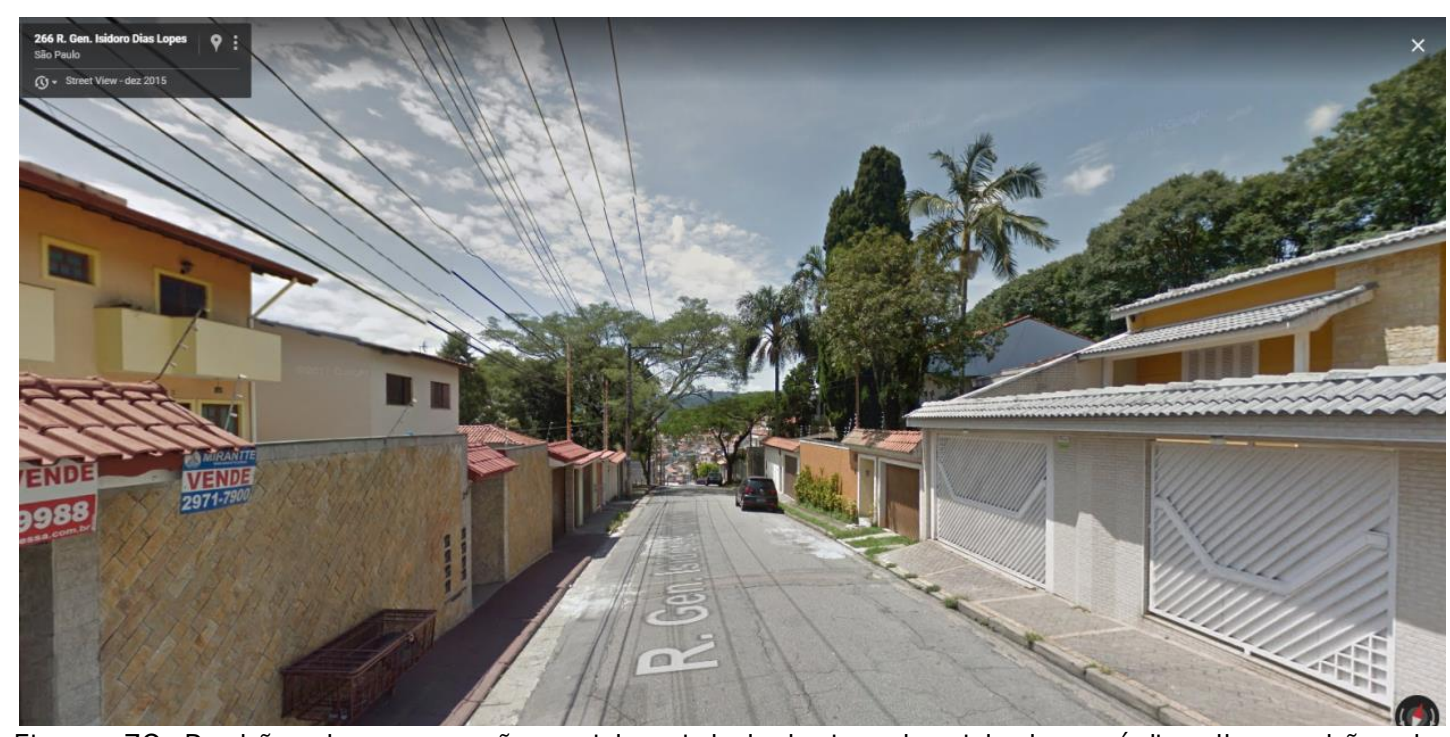

Figura 79. Padrão de ocupação residencial de baixa densidade, médio-alto padrão da Vila Amália, bairro localizado na bacia do Índio e fora dos limites do Horto Florestal. Fonte: Google street view, 2016.

A figura 80 classifica a Vila Amélia com ocupação residencial de médio-alto padrão, não mostrando a existência de comércios e seviços na área. Na vila existem apenas dois pontos de comércio de apoio aos moradores, como mostra a figura 81. A ocupação residencial médio-alto padrão, com alguns terrenos vazios ou construções precárias pode ser visto nas figuras 82,83 e 84 . 


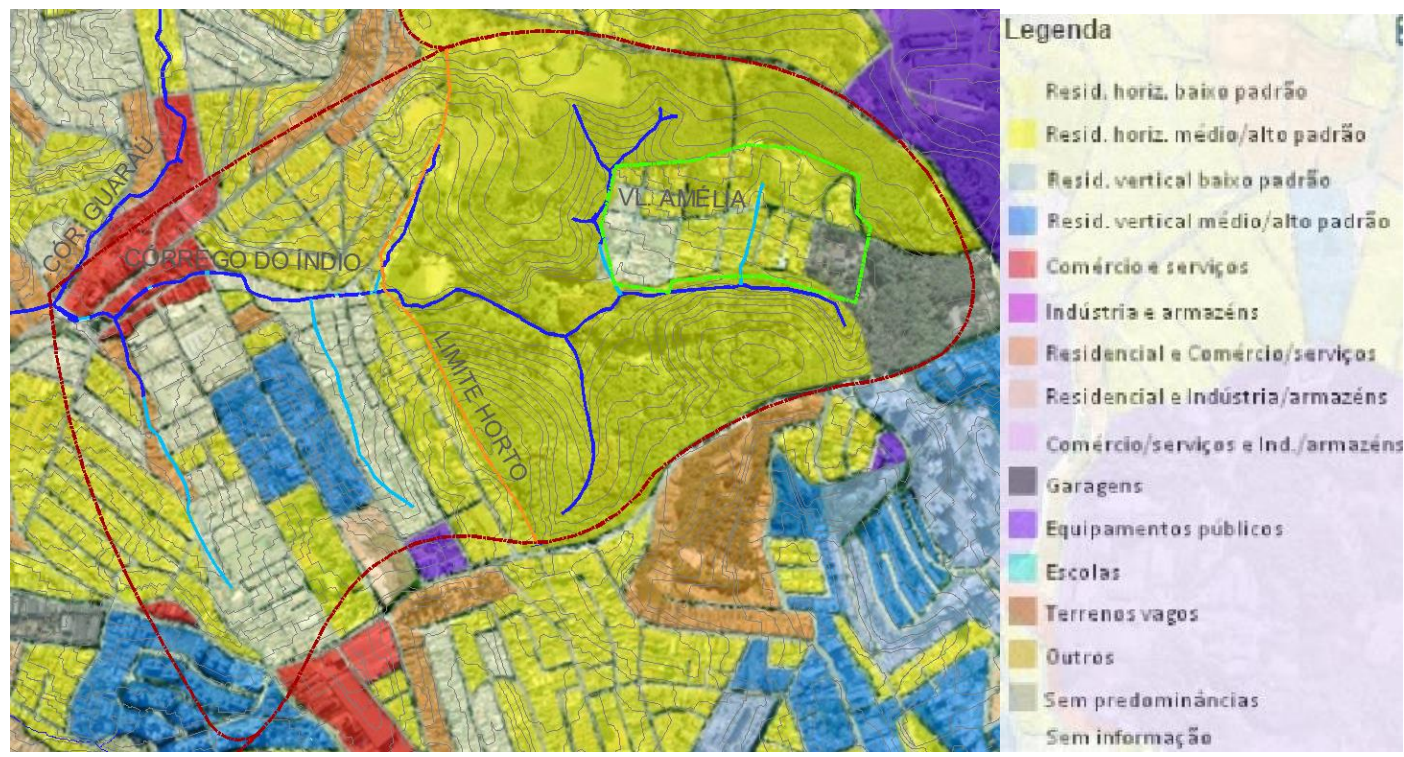

Figura 80. Imagem do Geosampa - uso e ocupação do solo onde a linha tracejada vermelha representa a bacia hidrográfica do córrego do Índio, a linha tracejada laranja mostra o limite do Horto Florestal, a linha tracejada verde clara mostra a Vila Amélia. Fonte: Trabalho da autora sobre imagem do Geosampa, 2014.

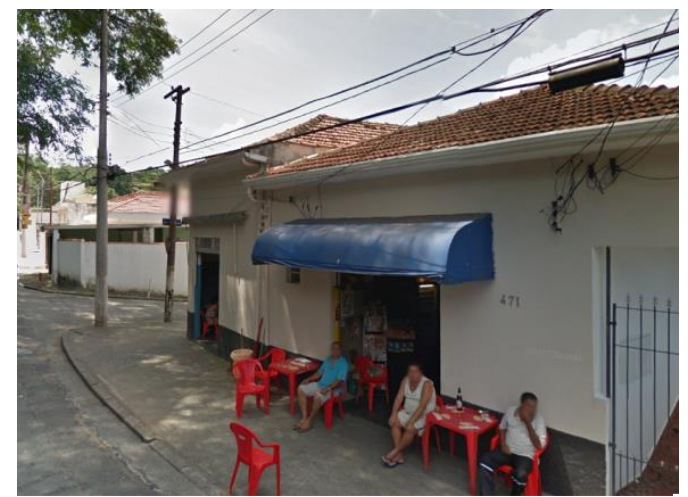

Figura 81. Parte de residência transformada em bar e loja de conveniências. Foto: Evy Hannes, 2016.

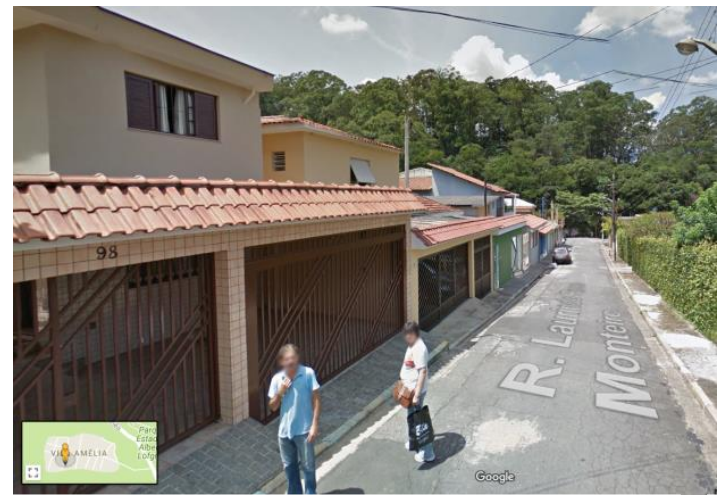

Figura 83. Residência padrão médioalto. Foto: Google Street View, 2011.

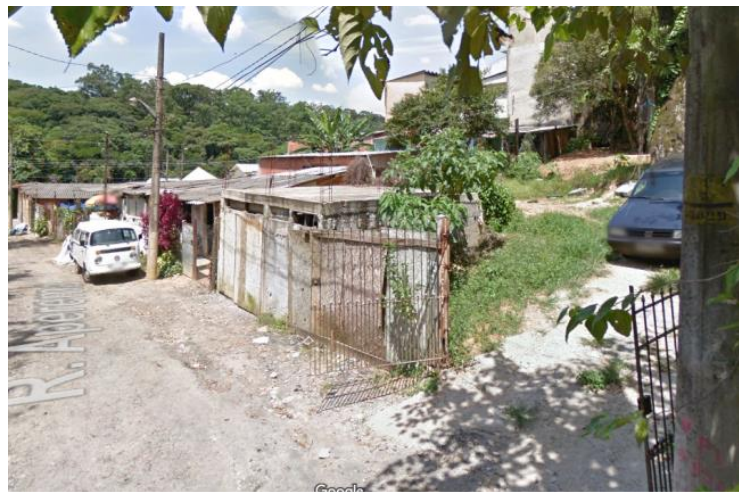

Figura 82. Lote com residência em situação precária. Fonte: Google Street View, 2011.

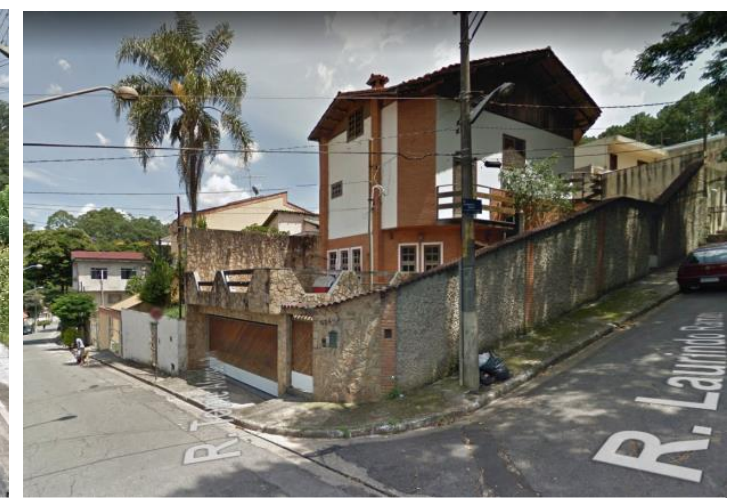

Figura 84. Residência padrão médio-alto. Foto: Google Street View, 2011. 
O novo zoneamento, aprovado em 2017, que pode ser visto na figura 85, classifica a área do Horto Florestal e a Vila Amélia, em seu interior, como ZEP, zona especial de proteção, que são zonas destinadas a parques estaduais e áreas de conservação, o que entra em conflito com a ocupação da Vila Amélia, um bairro residencial, já que nessas zonas apenas são permitidos o ecoturismo, pesquisa e educação ambiental.
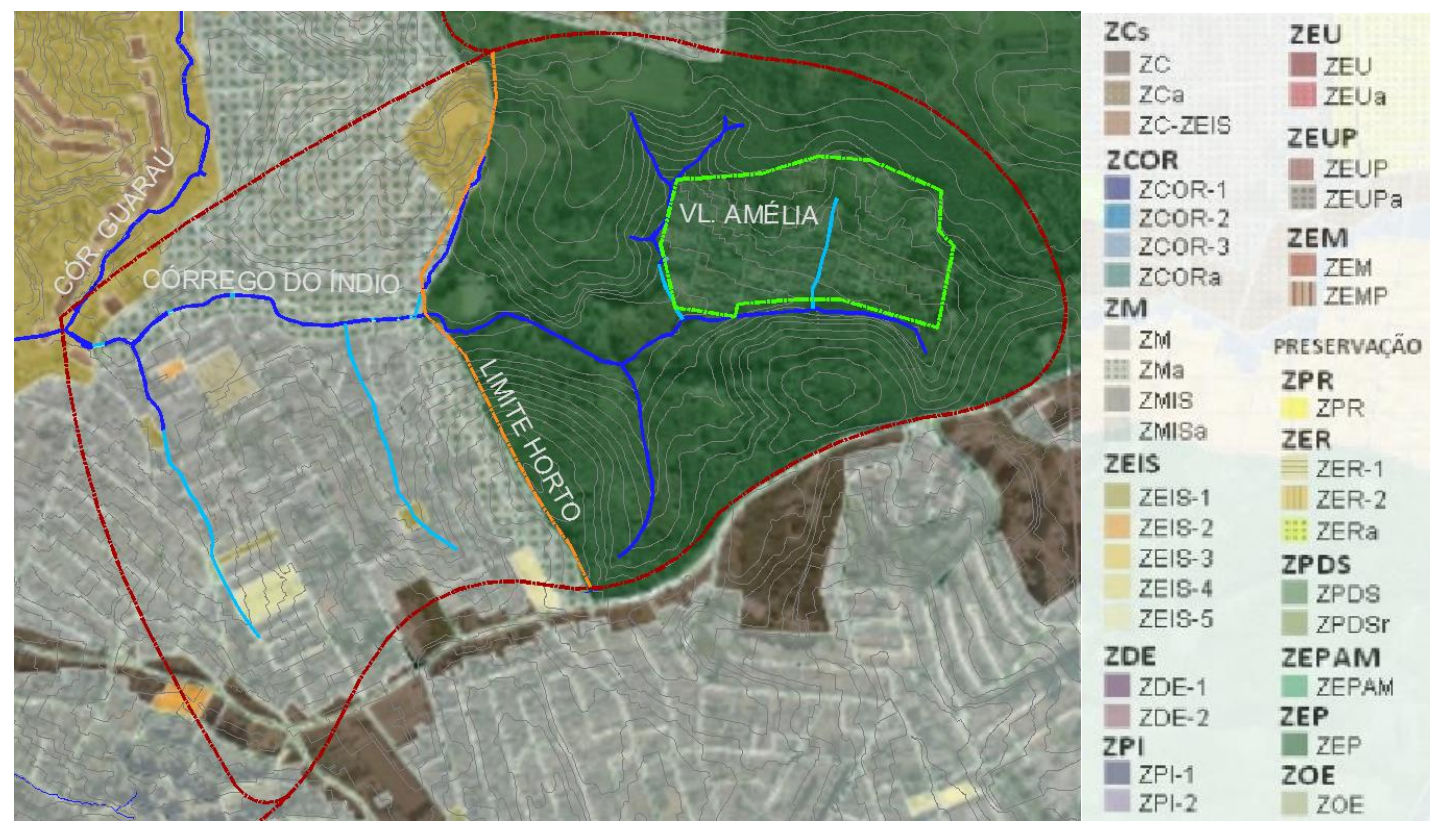

Figura 85. Zoneamento onde a linha tracejada vermelha representa a bacia hidrográfica do córrego do Índio, a linha tracejada laranja mostra o limite do Horto Florestal, a linha tracejada verde clara mostra a Vila Amélia. Trabalho da autora sobre imagem Geosampa 2014.

As demais áreas da bacia são classificadas como zona mista, que permite usos residenciais e não residenciais. Também há na área trechos classificados como ZEIS, áreas especiais de interesse social.

A densidade demográfica na Vila Amélia é baixa, até 92 hab./ha, com aproximadamente 130 unidades residenciais (levantamento da autora in loco, 2016). No trecho fora do parque tem densidade média de 146 a 207 hab./ha, como mostra a figura 86. 


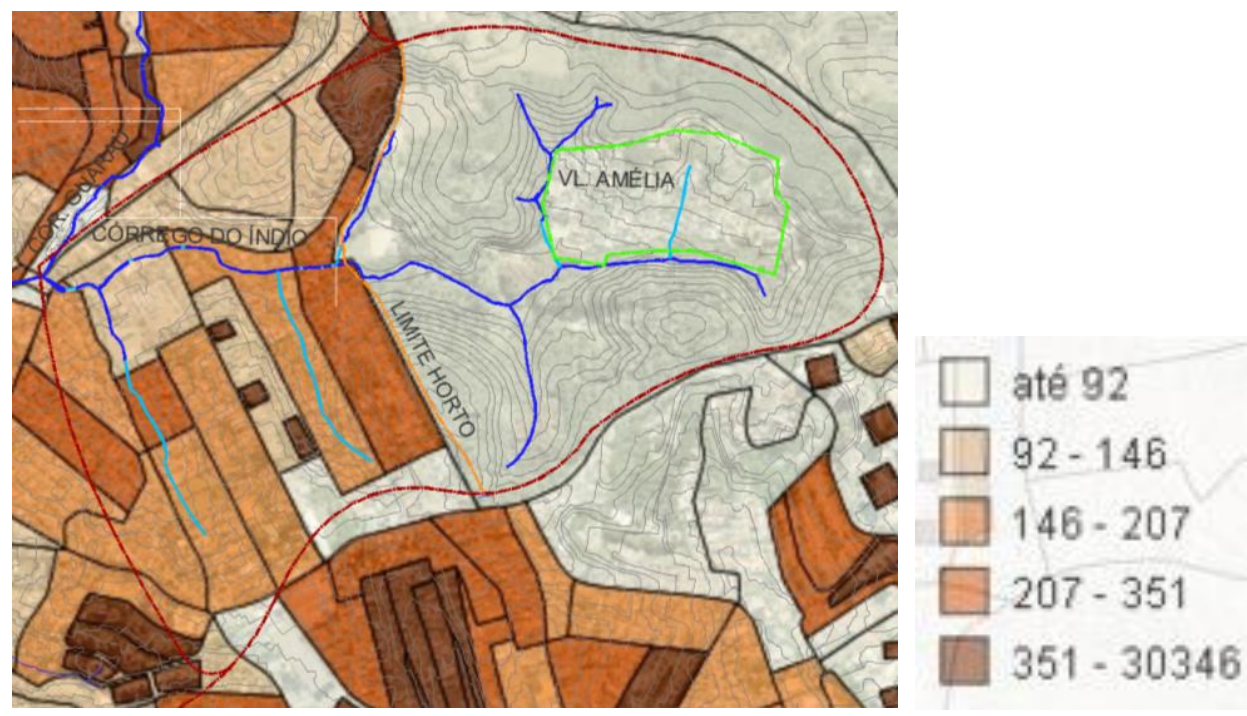

Figura 86. Densidade demográfica onde a linha tracejada vermelha representa a bacia hidrográfica do córrego do Índio, a linha tracejada laranja mostra o limite do Horto Florestal, a linha tracejada verde clara mostra a Vila Amélia. Trabalho da autora sobre imagem Geosampa 2014.

É considerada, em sua maior parte, área de muito baixa vulnerabilidade ambiental, ficando classificada como área de risco, com alta vulnerabilidade, apenas o anfiteatro de uma de suas nascentes, marcado em vermelho na figura 87.
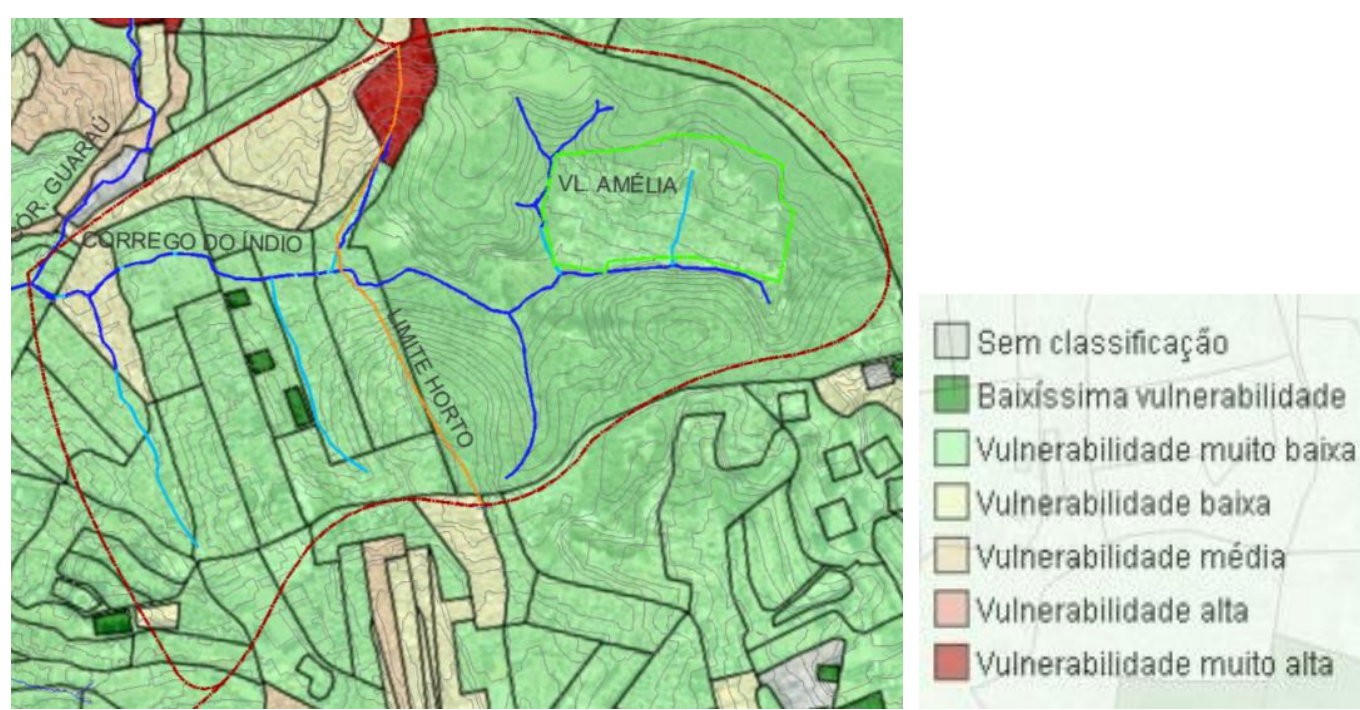

Figura 87. Áreas vulnerabilidade social onde a linha tracejada vermelha representa a bacia hidrográfica do córrego do Índio, a linha tracejada laranja mostra o limite do Horto Florestal, a linha tracejada verde clara mostra a Vila Amélia. Trabalho da autora sobre imagem Geosampa 2014. 


\subsection{INFRAESTRUTURA URBANA}

Em relação à mobilidade urbana, tanto a Vila Amália, quanto a Vila Amélia sofrem com a carência da mesma. Não possuem linhas de metrô, corredores de ônibus, terminais e nem ciclovias, sendo o terminal mais próximo o da Vila Nova Cachoeirinha, a aproximadamente $3 \mathrm{~km}$ de distância. A Vila Amália é servida de algumas linhas de ônibus, cerca de 5 , e a Vila Amélia por uma única linha que adentra seus limites, fazendo ponto final na mesma. Na Av. Parada Pinto, limite do bairro e da bacia hidrográfica, circulam diversas linhas que levam à linha norte sul do metrô e outras regiões da cidade. Importante ressaltar que Vila Amália e Vila Amélia não são integradas urbanisticamente devido à mata do Horto Florestal que fica entre as mesmas, sendo a ligação feita através das avenidas que circulam o Horto Florestal, Av. Parada Pinto e Av. Peri Ronchetti, que se liga à Santa Inês. Essas avenidas são as vias coletoras que ligam o bairro às artérias de maior fluxo da região norte.

O bairro da Vila Amália é dotado de equipamentos urbanos que atendem a escala do bairro como escolas, igrejas, escolas de ensino infantil, fundamental e médio e uma unidade básica de saúde. Possui comércio local e em seu limite um mini shopping center. Não possui hipermercados, sacolões ou feiras livres, equipamentos culturais, esportivos, Já o bairro da Vila Amélia possui apenas dois estabelecimentos comerciais, dois mercadinhos de bairro. Todas as outras necessidades diárias de seus moradores tem que ser atendida fora de seus limites, nos outros bairros da vizinhança.

A região não possui praças ou áreas livres de lazer e recreação além do Horto Florestal, que possui um núcleo de atividades com acesso pela vila Amália, como mostra a figura 88 e outro núcleo com acesso pela Vila Amélia, O Arboreto Vila Amália, que pode ser visto na figura 89, estando os dois desconectados. De forma geral os bairros apresentam 
calçadas estreitas e pouca arborização do sistema viário, o que fica claro nas figuras 83 e 84 .

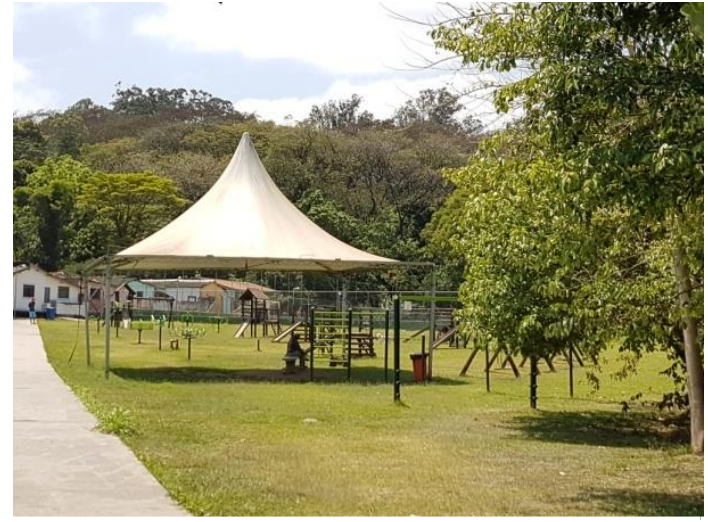

Figura 88. Núcleo de lazer do Horto Florestal com acesso pela Vila Amália. Foto: Evy Hannes, 2016.

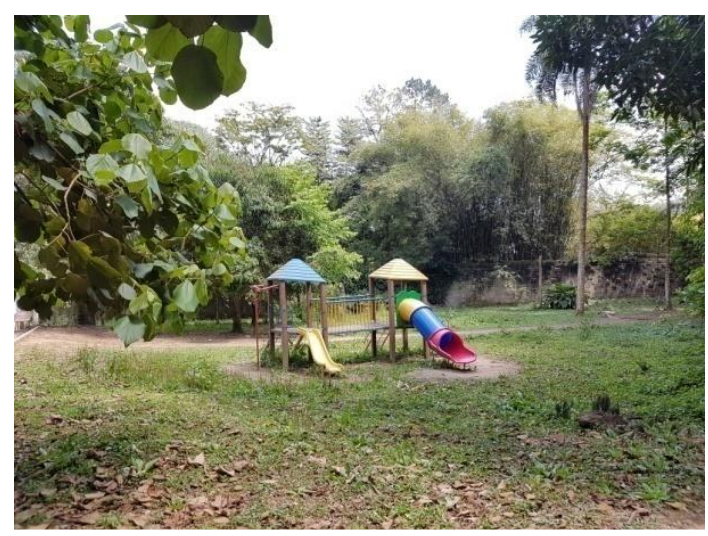

Figura 89. Núcleo de lazer Arboreto Vila Amália do Horto Florestal com acesso pela Vila Amélia. Foto: Evy Hannes, 2016.

A região é dotada de coleta de esgotos, mas mesmo assim algumas residências despejam conteúdo diretamente nos córregos, como se pode ver nas figuras 90 e 91.

Figura 91. Ao lado: despejo de esgoto residencial no córrego do índio. Foto: Evy Hannes, 2016.

Figura 90. Abaixo: despejo de esgoto residencial no córrego do índio. Foto: Evy Hannes, 2016.
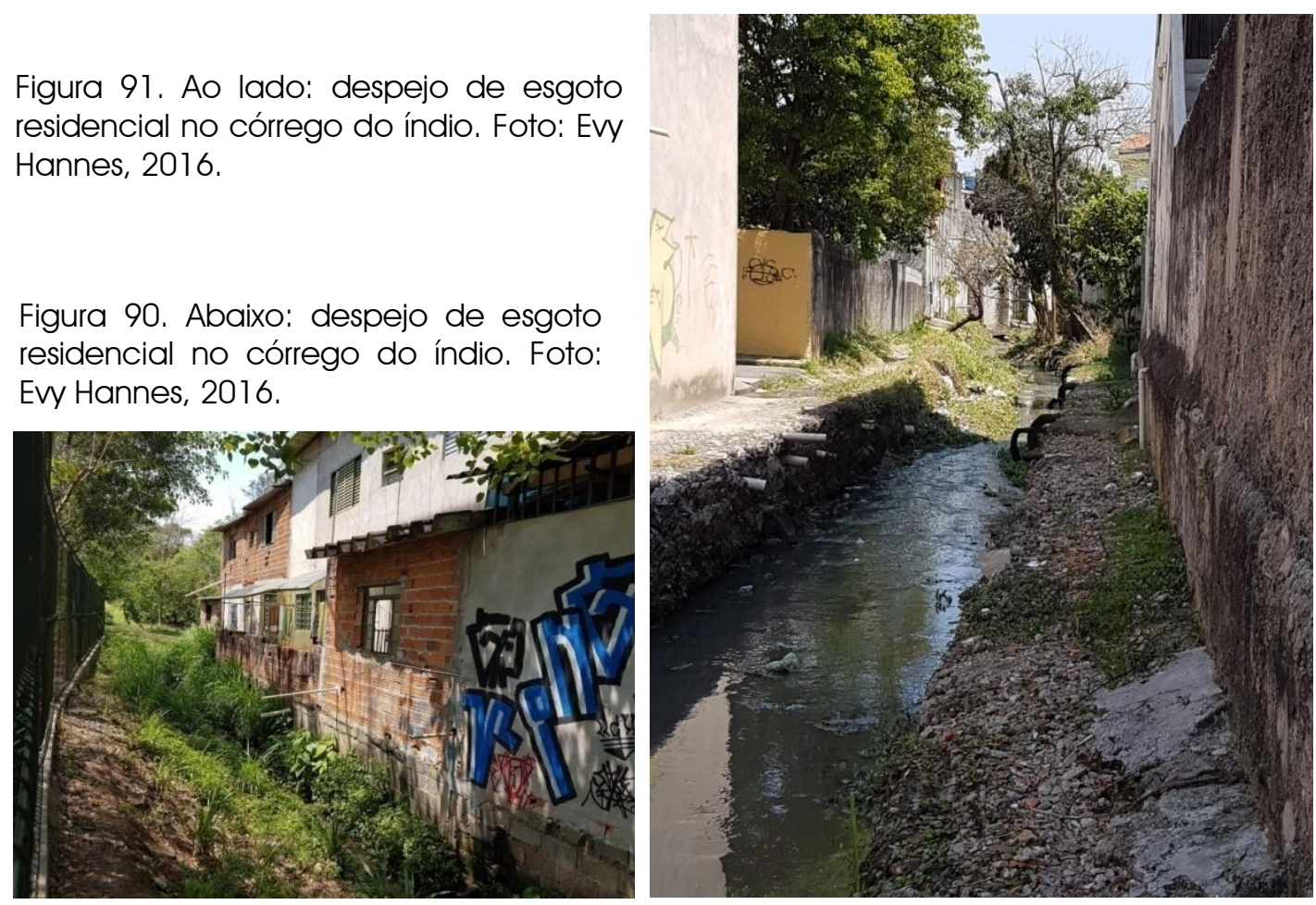
PARTE III. PLANO ECOLÓGICO PARA A BACIA DO ÍNDIO E PARA A VILA AMÉLIA 


\section{CAPÍTULO 6}

\section{DIRETRIZES DE INFRAESTRUTURA VERDE PARA A BACIA DO CÓRREGO DO ÍNDIO}

\subsection{ZONEAMENTO URBANO AMBIENTAL PARA A BACIA DO}

\section{CÓRREGO DO ÍNDIO}

Para que a proposta de diretrizes de intervenção - plano de infraestrutura verde estejam alinhados às características e reais necessidades da área, foi desenvolvido seu zoneamento urbano ambiental que traça os parâmetros resultantes do cruzamento dos dados do zoneamento ambiental, desenvolvido no capítulo 4 com o levantamento das questões urbanas presentes no local, apresentados no capítulo 5. Assim, temos um mapeamento que mostra as características de cada compartimento de paisagem, suas fragilidades, potencialidades e interface com 0 ambiente construído, criando base para 0 desenvolvimento de intervenções alinhadas aos processos naturais e sua capacidade de suporte, gerando menor impacto e desequilíbrio ambiental. Esse mapeamento deve seguir o desenho urbano existente, o desenho das quadras e avaliar as alterações já sofridas pelos elementos naturais e estrutura superficial da paisagem, como cortes, aterros e canalização de cursos d'água. (SCHUTZER, 2012). Foi desenvolvido com base na ideia de recuperação das nascentes e cursos d'água da cidade, propondo parâmetros que permitam a proteção e renaturalização dos mesmos. Essa determinação é possível nessa área devido à sua ocupação de baixa densidade que torna viável o processo de desapropriação de alguns lotes. Essas medidas, sempre que tomadas, serão trabalhadas conjuntas a ações de transferência ou venda de 
potencial construtivo. O resultado desse mapeamento pode ser observado na figura 92.
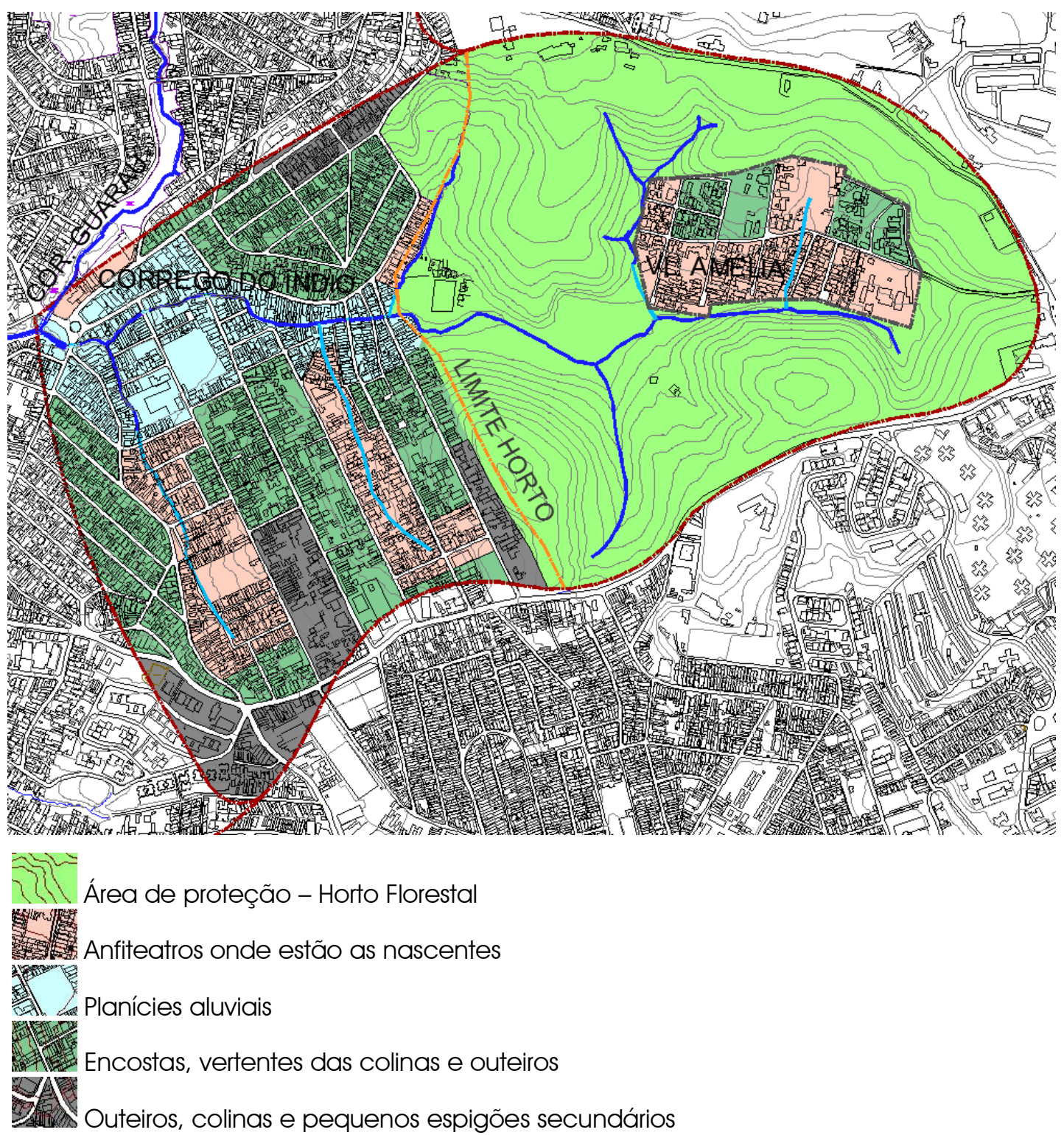

Figura 92. Zoneamento urbano ambiental do córrego do Índio, onde a linha tracejada vermelha representa a bacia hidrográfica do córrego do índio, a linha tracejada laranja mostra o limite do Horto Florestal, a linha tracejada cinza mostra a Vila Amélia, as linhas em azul escuro representam os cursos d'água que correm a céu aberto e as linhas em azul claro os cursos d'água canalizados ou intermitentes. Fonte: Trabalho da autora sobre desenho de Autocad do Geomapas, 2017.

Como estabelecido pelo zoneamento ambiental da bacia do córrego do Índio, no capítulo 4 desse trabalho, o compartimento dos outeiros, colinas e pequenos espigões secundários, deve incentivar a 
permeabilidade do solo para que o processo de infiltração possa abastecer o lençol freático, as nascentes e combater a super impermeabilização do solo, que acarretaria no aumento do escoamento superficial para as encostas. Elementos de infraestrutura verde que contribuiriam para esses processos são os jardins de chuva, as biovaletas e as lagoas de contenção de águas pluviais.

Dessa forma, as diretrizes de desenho ambiental para esse compartimento focam na questão da permeabilidade e arborização. Nos lotes deverá ser aumentada a taxa de permeabilidade para no mínimo $30 \%$ e incentivada a captação de águas pluviais, bem como a arborização dos quintais através de programas de incentivo público. Tais medidas ajudarão a aumentar o abastecimento das águas subterrâneas bem como combater o escoamento superficial nas áreas de encosta, aliviando as cheias das áreas mais baixas. Para as calçadas deve ser utilizado material permeável, como piso intertravado, canteiros grandes, do maior tamanho possível respeitando as normas de acessibilidade, de preferência em forma de jardins de chuva e implantada arborização extensiva. Para o sistema viário, nas ruas locais onde não há fluxo intenso de veículos e não trafegam ônibus e caminhões, pode ser prevista a implantação de ruas compartilhadas ou woonerfs, que utilizam piso permeável e aumentam a área disponível para implantação de jardins e áreas permeáveis. O coeficiente de aproveitamento dos lotes deve ser planejado de forma que os edifícios não formem barreiras à circulação dos ventos, apresentando recuos generosos entre si.

Os anfiteatros onde estão as nascentes, como dito anteriormente, são áreas importantíssimas para o equilíbrio ecológico do ambiente urbano e devem ser preservadas e, portanto, não devem ter sua ocupação incentivada. Devem ser trabalhadas com parques e áreas de lazer terraceadas, contemplando vegetação abundante e protegendo, assim, o entorno das nascentes. No caso de áreas com ocupação já consolidada, deve-se prever o congelamento do potencial construtivo 
como está, impedindo reformas e expansões, mas aumentando esse potencial em caso de transferência de potencial construtivo, incentivando assim a liberação de área para a recuperação das bordas dos cursos d'água e possível renaturalização destes. Áreas ao redor das nascentes devem ser protegidas e desapropriadas para criação de micro áreas de proteção permanente, que podem ser usadas como áreas de lazer pela população.

Nas encostas, vertentes das colinas e outeiros predomina o processo de escoamento superficial, que pode gerar erosão no solo e deslizamentos, carregando sedimentos para os cursos d'água e contribuindo com as enchentes. Devido a essas características, as áreas de solo aparente devem ser arborizadas para que as raízes da vegetação ajudem no controle do escoamento de água e na erosão do solo. Áreas com declividade maior que 60\% devem ser transformadas em áreas de lazer, não devendo ser ocupadas, minimizando os riscos de deslizamento, e devem ter tratamento de drenagem adequados, com terraceamento do solo e biovaletas. Para diminuir a velocidade do escoamento superficial devem ser incentivados 0 uso de pisos drenantes, jardins de chuva, biovaletas e áreas de contenção que segurem as águas por algum tempo antes de as devolverem ao sistema de captação de águas pluviais. Devem ser incentivados tetos verdes e outras formas de retenção de águas nas coberturas dos edifícios.

O compartimento das planícies aluviais ou várzeas tem como característica solos encharcados que não são favoráveis à infiltração. Constituem áreas muito sensíveis que devem ser destinadas a parques e onde devem ser utilizadas wetlands para filtragem das águas e bacias de detenção que ajudem a amenizar o transbordamento dos córregos e rios. A ocupação deve ser evitada, mas caso ocorra, deve ser de baixa densidade, destacada do solo e deve respeitar as áreas de proteção mínima estabelecidas pelo Código Florestal. Para incentivar sua liberação para a construção de parques lineares ao longo das águas, sugere-se 
trabalhar com a venda ou transferência do potencial construtivo desses lotes, que poderia ainda ser aumentado. Para o que está construído, congela-se o potencial construtivo. É interessante que essas áreas, assim como os anfiteatros que contém as nascentes, sejam transformadas em áreas de operação urbana com projetos específicos.

A área de proteção do Parque Estadual foi destacada em uma outra categoria já que segue normas específicas referentes aos compartimentos a que pertence, o das encostas, vertentes das colinas e outeiros e dos anfiteatros onde estão as nascentes.

\subsection{PLANO DE INFRAESTRUTURA VERDE PARA A BACIA DO}

\section{CÓRREGO DO ÍNDIO}

Para iniciar o plano do sistema de infraestrutura verde para o córrego do Índio, foram a princípio identificadas as áreas potenciais para integração dessa rede verde-azul, como praças, áreas livres, jardins privativos, áreas verdes, canteiros e rotatórias de vias públicas, áreas de encostas, córregos a céu aberto, canalizados e arborização urbana. Em seguida, foi feito estudo de desapropriações necessárias para que os trechos canalizados de dois braços de córregos pudessem ser naturalizados e ter suas margens de proteção reconstituídas. Essas áreas, somadas, permitem a criação de um sistema de áreas livres que vai do Horto Florestal ao encontro com o córrego do Guaraú, podendo ser estendida no sentido da matriz ecológica do Parque Estadual da Cantareira e do rio Tietê, potencializando os ganhos ecológicos desse corredor verde e possibilitando a criação de um parque fluvial que reabilite os serviços ecossistêmicos perdidos da região e que também possa funcionar como uma estrutura alternativa de transporte sustentável (bicicletas e caminhar a pé), lazer e integração social de forte caráter simbólico para esses bairros. 
O sistema vai fornecer diversos serviços ecossistêmicos à população, aumentando a qualidade de vida dos moradores da região e ofertando novas áreas de lazer e contemplação da paisagem. Na figura 93 a seguir podem-se observar, em verde mais escuro, as áreas recuperadas nas margens dos córregos, que formam um pequeno parque linear que protege as nascentes e que conta com wetlands para filtragem de águas e bacias de contenção para seu armazenamento em dias mais chuvosos. As áreas de convergência de águas, onde afluentes se unem ao córrego principal, foram ampliadas para permitir seu extravazamento, sendo no encontro entre os córregos do Índio e do Guaraú prevista uma bacia de contenção, em área de melhoria do desenho do sistema viário, para ajudar a impedir os alagamentos constantes do local.

Algumas áreas que se encontram livres de construção foram transformadas em áreas de lazer para a população e podem também ser trabalhadas como jardins e hortas comunitárias. As áreas livres que estejam fora dos compartimentos de proteção, que são os anfiteatros e as planícies aluviais, podem ser trabalhadas como alternativa habitacional de relocação das residências desapropriadas. As vias foram trabalhadas de diferentes formas, intercalando jardins de chuva, biovaletas e piso drenante, dependendo do compartimento ambiental em que estão inseridas. Tanto nas vias, como nas áreas livres, privadas e públicas, é prevista intensa arborização. Para todas as construções incentiva-se o uso de telhados verdes e outras formas de armazenamento e reutilização de águas pluviais.

Para o compartimento dos outeiros, colinas e pequenos espigões secundários, onde se deve principalmente incentivar a permeabilidade do solo, prevê-se o tratamento das vias com jardins de chuva. Calçadas terão a utilização de pisos drenantes. Nos lotes deverá ser mantida taxa de permeabilidade mínima de 30\% em área verde, incentivando-se o aumento desse percentual. Telhados farão a captação das águas pluviais e seu gradual despejo nas áreas permeáveis. 
Nas encostas, vertentes das colinas e outeiros, onde predomina 0 processo de escoamento superficial, as vias serão tratadas com biovaletas que diminuam a velocidade desse escoamento, permitindo também alguma infiltração. Calçadas terão pisos drenantes. As vias mais locais serão transformadas em woonerfs, permitindo a criação de mais áreas de infiltração, com jardins de chuva, que contribuam para diminuir o volume do escoamento superficial. Lotes seguirão o percentual mínimo de 30\% de área permeável e edificações terão incentivos para captação de águas pluviais e utilização de telhados verdes.

Os anfiteatros onde estão as nascentes, áreas de grande importância ecológica, serão restaurados. Nascentes serão protegidas, arborizadas e transformadas em mini áreas de proteção permanente. Os leitos dos córregos serão renaturalizados.

O compartimento das planícies aluviais constitui a área natural de alagamento dos cursos d'água e deve ser recuperado. O plano prevê a recomposição de parte da várzea do córrego do Índio com a criação do corredor verde da várzea do Índio. Como dito anteriormente, serão criadas wetlands ao longo do curso d'água e bacias de contenção em áreas livres.

Para a área do Parque Estadual Alberto Lofgren, que circunda a Vila Amélia, é prevista a criação de trilhas elevadas ao longo dos cursos d'água e suas nascentes (em vermelho na figura 94), para que os visitantes possam ter contato com essas águas, admirando a beleza do elemento natural e entendendo seu valor como parte desse conjunto ecológico de grande valor, despertando assim a vontade de protegê-lo e contrubuir com sua conservação. 


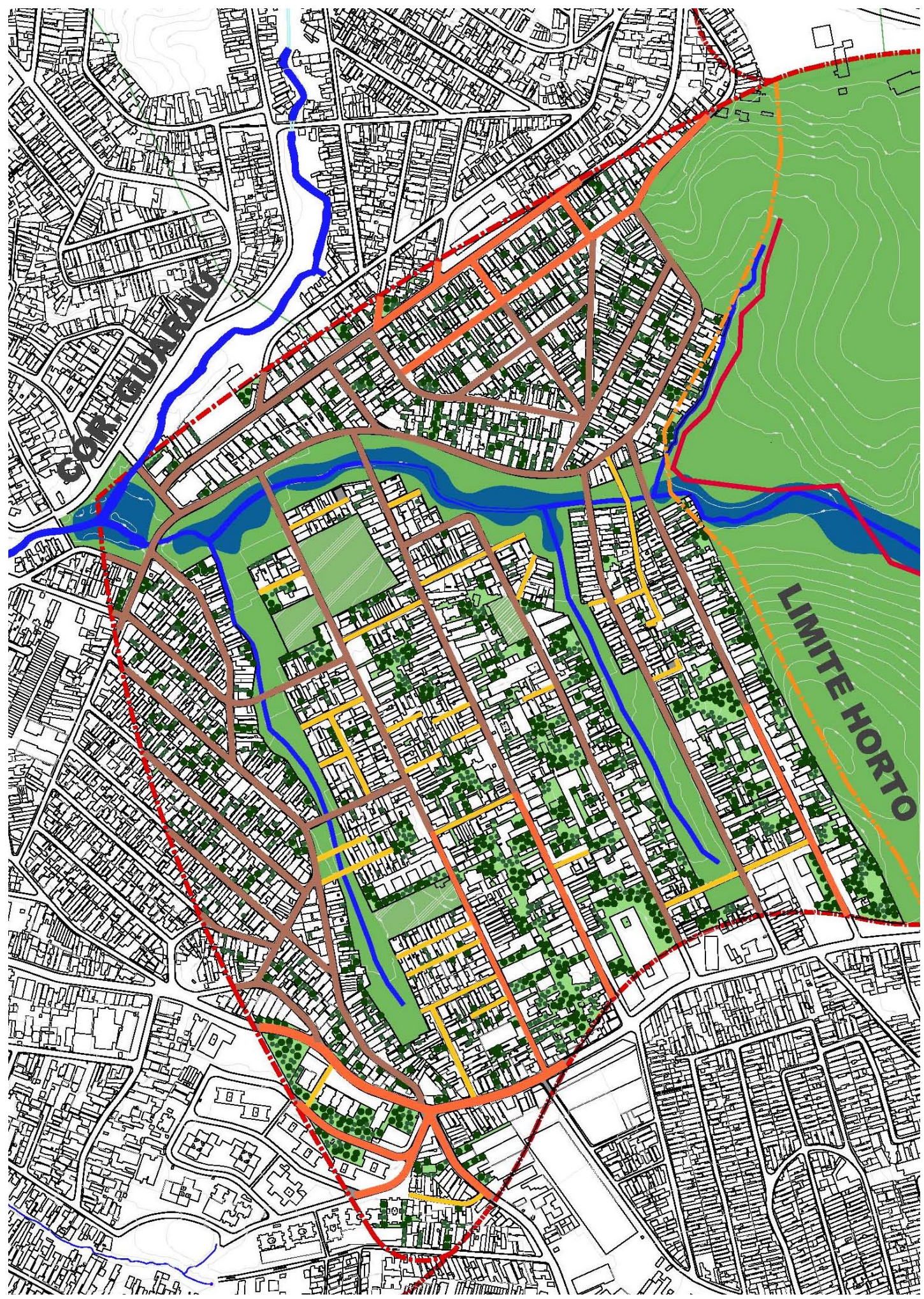

Figura 93. Plano de infraestrutura verde para a bacia do córrego do Índio, onde a linha tracejada vermelha representa a bacia hidrográfica do córrego do Índio, a linha tracejada laranja mostra o limite do Horto Florestal, o laranja representa jardins de chuva, o amarelos os woonerfs, o marrom as biovaletas, o verde escuro os corredores verdes ao longo das águas e o verde claro as áreas livres de usos coletivo. Os pontos verdes mostram a arborização que pode ser implantada nos lotes particulares. Trabalho da autora sobre base Geosampa. 
A criação de um manual de infraestrutura verde poderia ajudar e incentivar os moradores a transformar seus lotes com a adoção de medidas como a implantação de tetos verdes, paredes verdes, jardins de chuva, arborização e hortas. São medidas simples e que, adotadas no coletivo, contribuiriam bastante para a transformação do bairro em uma região mais sustentável.

A gestão das áreas verdes e do parque fluvial ficará a cargo da Prefeitura Municipal, do DEPAVE e das Subprefeituras da Casa Verde e de Santana, que deverão firmar acordo de cooperação para trabalhar as águas comuns às suas jurisdições. Os coletivos e a comunidade local também terão papel importante no quesito manutenção e cuidados dessas áreas, atuando como fiscais e parceiros dos órgãos públicos.

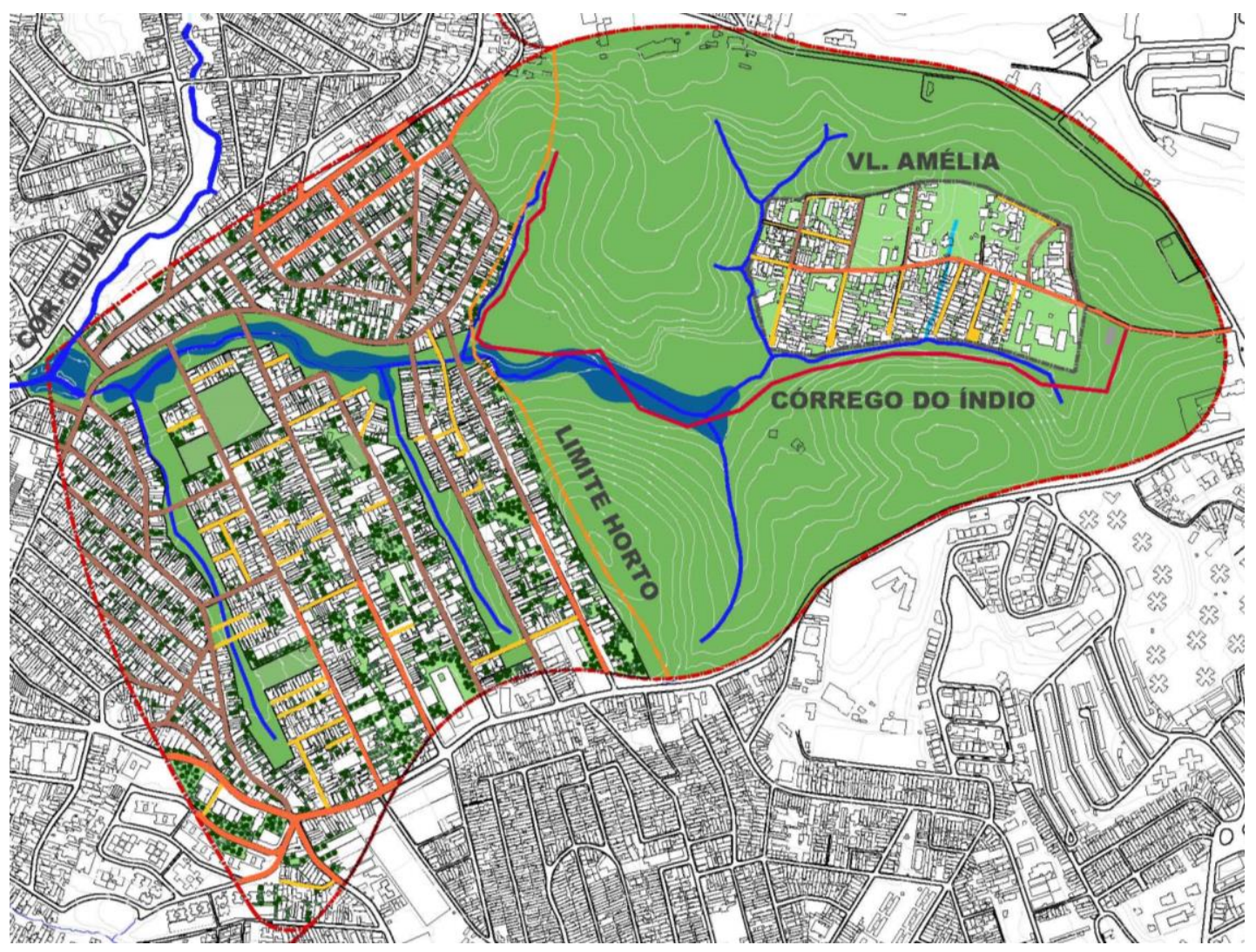

Figura 94. Plano de infraestrutura verde para a bacia do córrego do Índio onde a linha tracejada vermelha representa a bacia hidrográfica do córrego do Índio, a linha tracejada laranja mostra o limite do Horto Florestal, a linha tracejada cinza o limite da Vila Amélia, o vermelho mostra as novas trilhas elevadas ao longo dos cursos d'água. Trabalho da autora sobre base Geosampa. 


\section{CAPÍTULO 7}

\section{DIRETRIZES DE INFRAESTRUTURA VERDE PARA A ECOVILA AMÉLIA}

\subsection{ZONEAMENTO URBANO AMBIENTAL PARA A VILA AMÉLIA}

A figura 95, a seguir, apresenta o zoneamento urbano ambiental da Vila Amélia e mostra que nela existem dois compartimentos diferentes: anfiteatros onde estão as nascentes e encostas das colinas e outeiros. Independente das características de cada compartimento e do que seu zoneamento ambiental sugere, é necessário ressaltar que a comunidade encontra-se inserida em meio à área de proteção do Horto Florestal, área de densa vegetação, com diversas nascentes que, portanto, deve seguir diretrizes que minimizem o impacto causado às mesmas. Assim, deve ser proibido o adensamento da área, que deveria ser caracterizada como zona especial de baixa densidade e proteção ambiental pelas leis de zoneamento. Nela deve ser trabalhada intensamente a arborização e o aumento da permeabilidade do solo, que deve ser de no mínimo $30 \%$, incentivando-se índices maiores através de contrapartidas.

Como colocado anteriormente, no compartimento das encostas, vertentes das colinas e outeiros, que equivale a cerca de 30\% da área da vila, predomina o escoamento superficial, que deve ser combatido através de medidas ligadas ao aumento da permeabilidade do solo e contenção das águas da chuva. A declividade média do local é de $25 \%$, o que não configura área de risco de deslizamentos e tem grande potencial para aplicação de conceitos de infraestrutura verde e ecologia urbana, como jardins de chuva e biovaletas, que farão 0 trabalho de retardar 0 escoamento superficial. 
Os outros cerca de $70 \%$ do território da Vila Amélia fazem parte do compartimento dos anfiteatros onde estão as nascentes, áreas valiosíssimas para o equilíbrio ecológico já que são responsáveis pelo abastecimento e proteção das nascentes. Essas áreas deveriam ser trabalhadas como parques, com as bordas dos cursos d'água protegidas, mas se encontram ocupadas, em um dos lados de suas margens, na Vila Amélia. Do outro lado dessas margens está o Parque do Horto Florestal. Uma nascente encontra-se protegida no interior da vila e corre canalizada para o córrego do Índio.

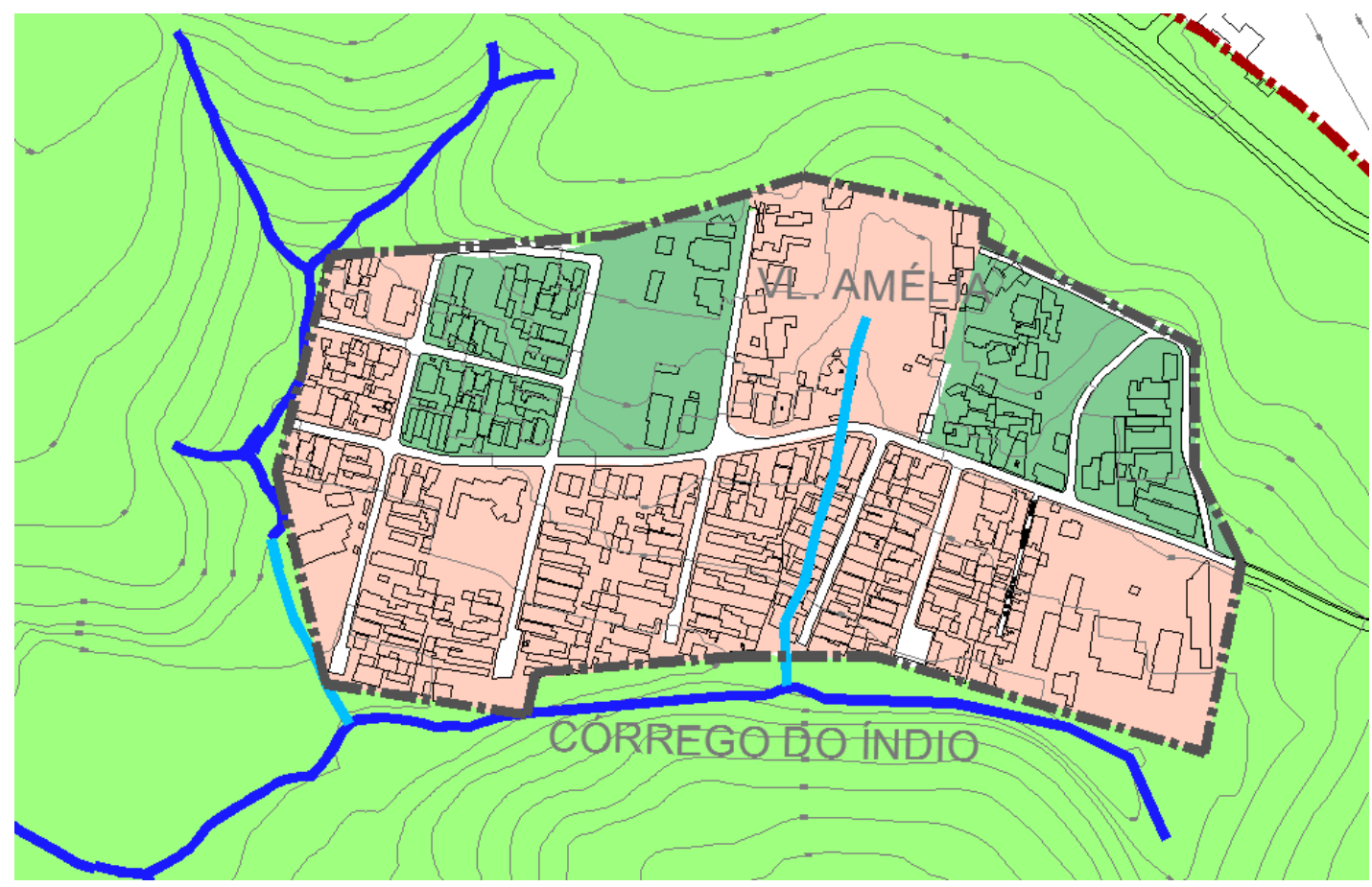

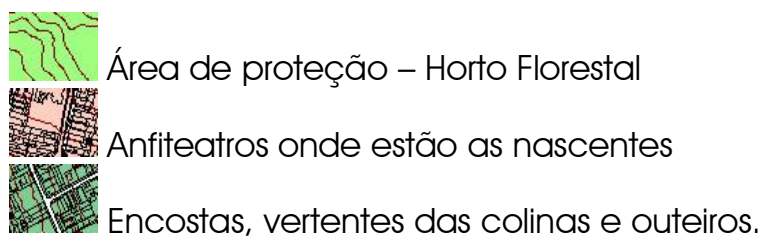

Figura 95. Zoneamento ambiental da Vila Amélia. As linhas em azul escuro representam os cursos d'água que correm a céu aberto e as linhas em azul claro os cursos d'água canalizados ou intermitentes. Fonte: Trabalho da autora sobre desenho de Autocad do Geomapas, 2017.

Considerando o atual estado de consolidação dessa comunidade, o que deve ser feito é congelar o potencial construtivo como se encontra, 
incentivando medidas que aumentem a permeabilidade do solo, aumentem a vegetação e que devolvam as águas pluviais limpas aos cursos d'água. Despejo de esgoto e águas não tratadas nos córregos deverão ser revertidos.

\subsection{PLANO DE INFRAESTRUTURA VERDE PARA A ECOVILA AMÉLIA}

O plano de infraestrutura verde para a Vila Amélia, ilustrado pela figura 96, foi desenvolvido com base nas questões levantadas pelo zoneamento ambiental urbano da área, que compreende dois compartimentos de paisagem: os anfiteatros onde estão as nascentes e as vertentes e encostas das colinas e outeiros e também com base nos desejos se seus moradores, que querem transformar o local em uma ecovila e que foram expressos através de seu representante, Sr. Roberto Lobo, que gentilmente os compartilhou conosco. Devido ao número reduzido de residências existentes no local e ao fato de, apesar de chegarem próximas à borda dos cursos d'água, estes terem a margem oposta protegida pela massa arbórea do Parque Estadual, não foram consideradas desapropriações ao longo destes. O córrego canalizado será mantido assim já que sua nascente encontra-se protegida dentro de uma propriedade particular.

Na vila não existem áreas públicas, estando as áreas livres disponíveis distribuídas entre os quintais das residências e as vias. São nessas áreas que o plano terá um de seus focos principais. A Rua Tomé Afonso de Moura, via única de acesso à vila Amélia, será a única que terá piso de asfalto, mas ele será trocado por asfalto drenante. As demais ruas serão transformadas em ruas compartilhadas, ou woonerfs (figura 97), e terão calçamento de piso intertravado, drenante. Nelas não haverá separação entre leito carroçável e calçada, prezando a boa convivência entre pedestres e diferentes modais de transportes e transformando as ruas em locais sombreados e bem agradáveis, funcionando também como 
áreas de estar. As vias pertencentes ao compartimento das encostas, marcadas em marrom na figura 96, tem inclinação maior e terão biovaletas implantadas em seu comprimento que retardarão o escoamento das águas e ajudarão a fazer uma primeira filtragem destas. As demais terão jardins de chuva que ajudarão no aumento da permeabilidade do solo. Em todas as vias serão plantadas árvores e a fiação será subterrânea, para evitar conflitos com a arborização e também riscos para a avifauna.

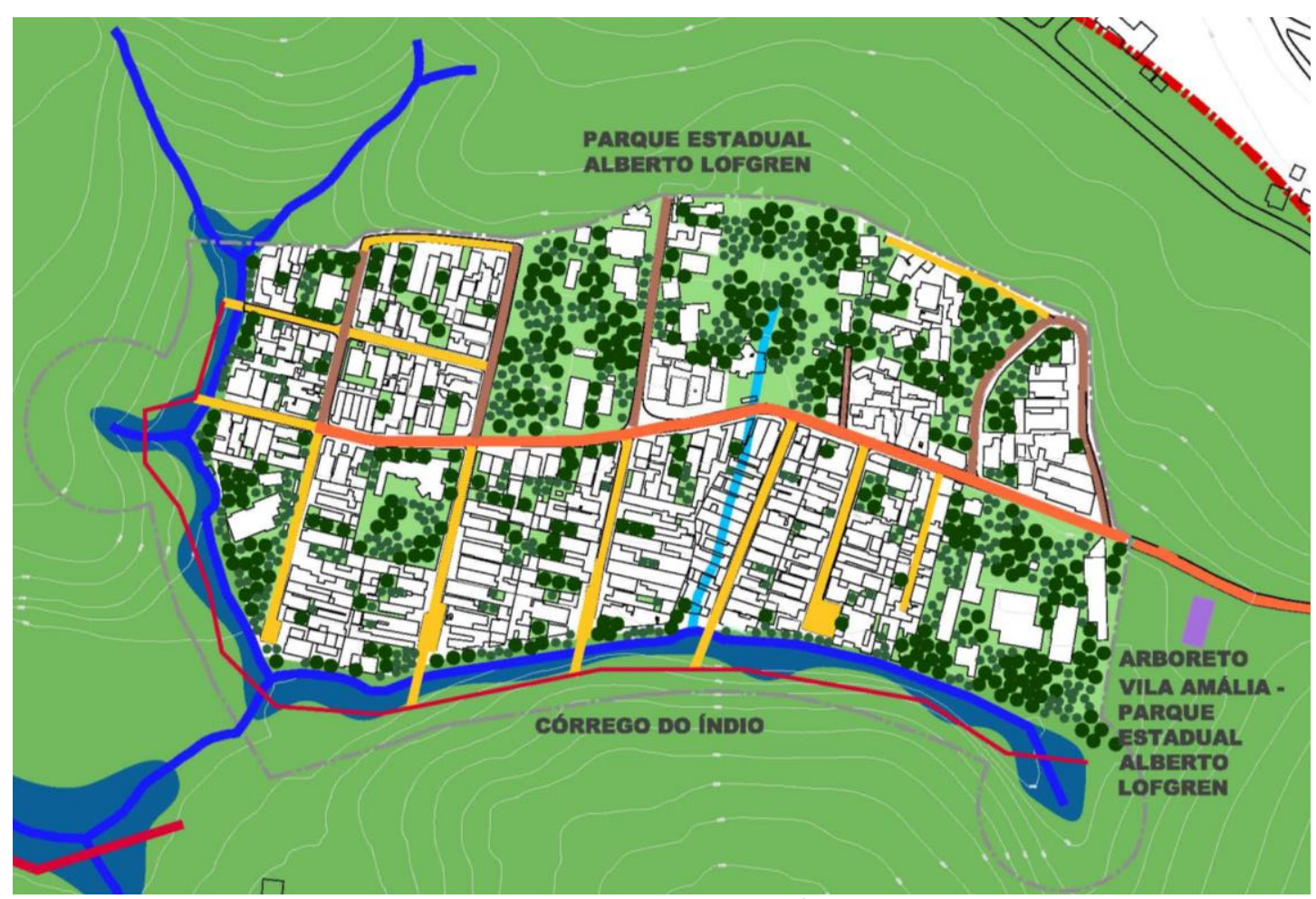

Figura 96. Plano de infraestrutura verde para a Vila Amélia onde o laranja representa a via estrutural da comunidade que receberá tratamento de jardins de chuva e piso drenante, o amarelo representa as ruas que terão jardim de chuva, o marrom mostra o tratamento com biovaletas, o verde escuro as áreas protegidas do parque estadual, o verde claro as áreas livres que deverão ser arborizadas e permeabilizadas, o azul escuro os cursos d'água que correm a céu aberto, o azul claro o curso d'água que corre canalizado sob residências, em vermelho a pista de caminhada elevada em meio a mata e ao longo das águas e em cinza tracejado o novo perímetro do cercamento da área. Trabalho da autora sobre base Geosampa.

Para os quintais particulares será imperativo transformá-los em gramados drenantes e o aumento da permeabilidade existente será incentivada através de contrapartidas. Esses espaços também deverão 
receber o plantio de árvores e serão incentivadas práticas ligadas à agricultura urbana e a implantação de paredes verdes. Telhados verdes também são bem vistos, bem como a captação e reuso de águas pluviais. O potencial construído dessas residências será congelado, não sendo autorizado nenhum tipo de construção extra dentro da Vila Amélia.

A área do núcleo Arboreto Vila Amália, ao lado direito da vila, como mostra a figura 96, terá papel importante no planejamento da ecocomunidade. Será utilizado como local de experiências, núcleo de apoio e centro comunitário, escola de educação ambiental, centro de compostagem, área para desenvolvimento de hortas coletivas (estas já em estágio de implantação na data de desenvolvimento deste trabalho Outubro de 2017) e área de lazer.

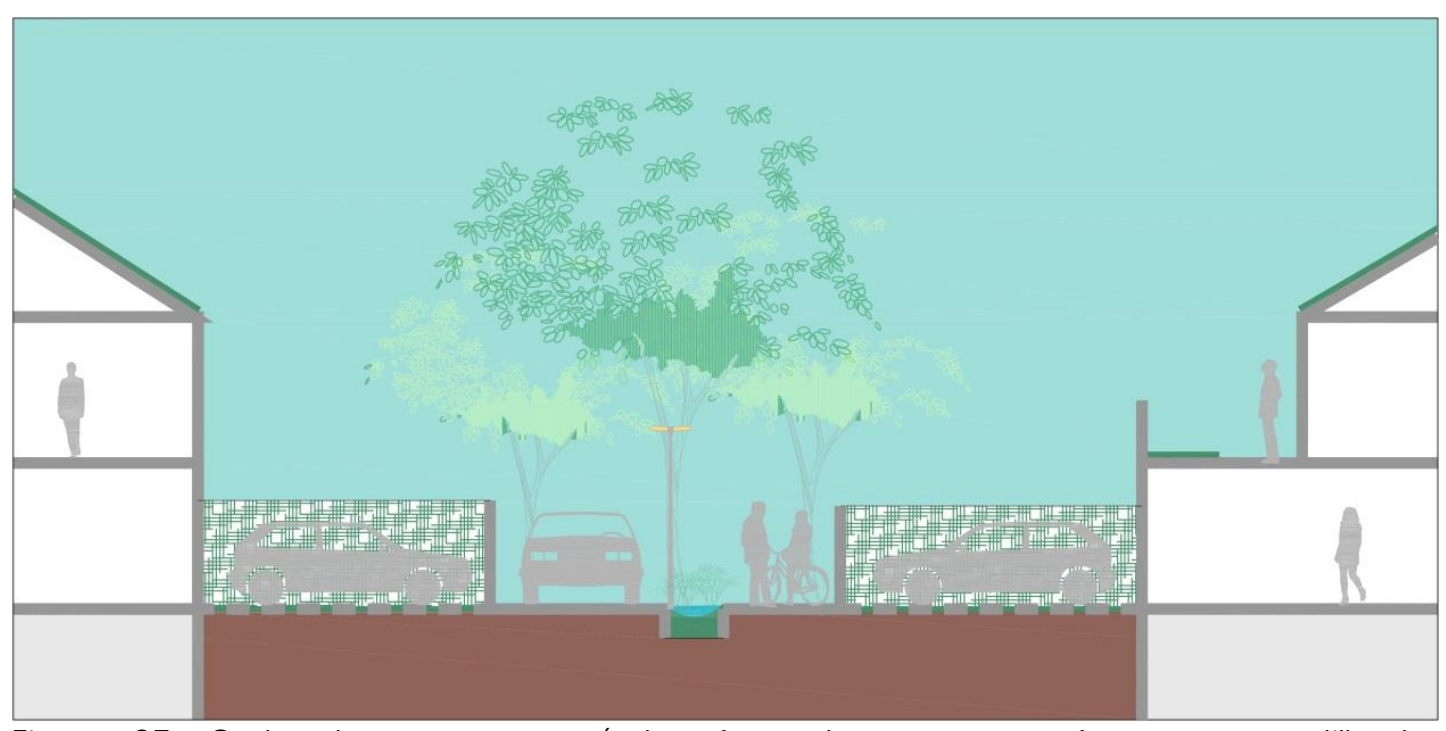

Figura 97. Corte de rua que será transformada em woonerf, rua compartilhada, mostrando os telhados verdes, paredes verdes, piso drenante, arborização e biovaletas.

O segundo foco do plano será a criação do parque fluvial do córrego do Índio, já citado no plano para a bacia do córrego no capítulo 6.2, que terá um trecho dentro do perímetro da Vila Amélia. Também foi dito anteriormente que os moradores da vila construíram um muro em seu perímetro na tentativa de melhorar a segurança do local, já que bandidos se escondiam na mata para assaltar os moradores. O muro é um elemento importante para a comunidade e por isso será mantido, mas na 
forma de alambrados, que permitam a visão do verde exuberante que cerca a área e em posição recuada, adentrando a área do Parque Estadual e permitindo a recuperação do córrego e o tratamento adequado de suas margens. O gradil respeitará os afastamentos estipulados pelo Código Florestal, de 30m nas margens do córrego e 50m de raio ao redor das nascentes. O parque fluvial contará com trilhas elevadas de $700 \mathrm{~m}$ de comprimento e acessíveis, que permitam caminhar ao longo das águas, constituindo importante espaço de lazer que os moradores carecem e também construindo forte simbolismo de valorização e de proteção das águas, bem como dos benefícios que ela pode agregar à qualidade de vida da comunidade. A figura 98 ilustra a situação pretendida.

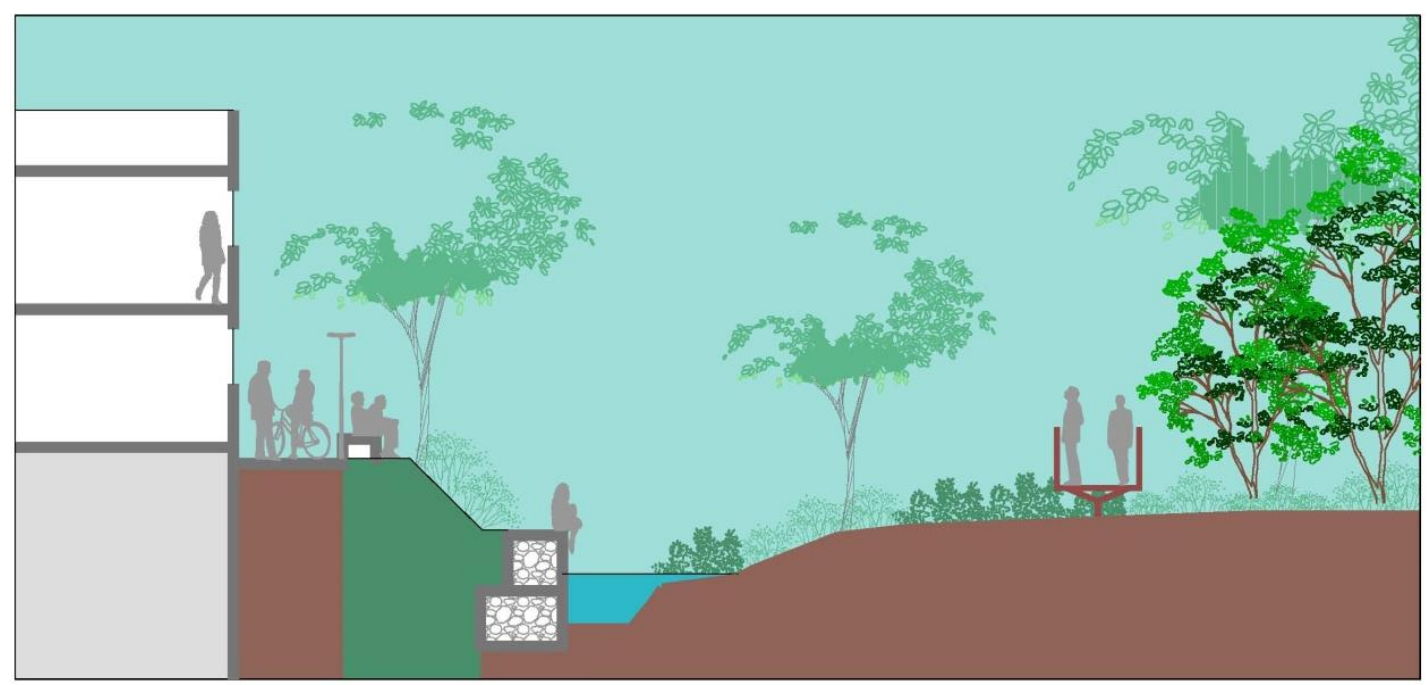

Figura 98. Corte ilustrando o cenário pretendido com a implantação do parque fluvial do córrego do Índio que mostra área de lazer entre as construções e as margens do curso d'água e a trilha elevada em meio à vegetação. Trabalho da autora.

A gestão desses espaços será compartilihada pelo Instituto Florestal, que cederá a área para a construção do parque fluvial e que tem grande interesse na recuperação desses cursos d'água e proteção das nascentes, entre a Subprefeitura de Santana-Casa Verde, responsável por toda a área do Parque Estadual, e pela AMOVA, Associação dos moradores da Vila Amélia, que atuarão como fiscais do novo espaço de lazer, ajudando na sua conservação e limpeza. 


\section{CONSIDERAÇÕES FINAIS}

Seria a infraestrutura verde uma ferramenta capaz de reestruturar os espaços urbanos e de potencializar a formação de comunidades ecológicas? Após as análises desenvolvidas nessa dissertação, é possível dizer que sim. A infraestrutura verde, como instrumento que desenha e transforma a paisagem através da gestão dos serviços ecossistêmicos produzidos pelos elementos naturais, pode funcionar como estrutura do desenho urbano para a construção de cidades mais equilibradas, que considerem a capacidade de suporte dos ecossistemas locais e as dinâmicas dos elementos que compõem os diferentes compartimentos de paisagem do mosaico urbano.

Com o desenvolvimento das pesquisas no ramo da ecologia e do urbanismo ecológico, torna-se evidente que usufruir da paisagem, de seus fragmentos verdes e de suas águas de maneira estética, apenas como componentes de embelezamento das cidades, não é mais aceitável, uma vez que se sabe que, trabalhando em conjunto, através da formação de uma rede, eles tem sua performance ampliada, podendo fornecer diversos benefícios aos sistemas urbanos.

Além disso, a grande aceitação do urbanismo ecológico por todo o mundo demonstra que a população apoia e necessita dessa nova forma de urbanismo, que prioriza o equilíbrio entre natural e construído, proporcionando melhor qualidade de vida. Nesse contexto, as ecocomunidades surgem como modelo que busca uma resposta aos desafios ambientais, econômicos, sociais e que pode se apresentar como alternativa viável para os problemas relativos à alimentação, transportes, habitação e infraestrutura urbana, enfrentados pelas grandes cidades do século XXI.

Com base nesses novos paradigmas, surgem diferentes padrões de ecocomunidades relativos a diversas escalas do urbano, todos 
carregando conceitos referentes a tecnologia verde, desenvolvimento econômico e social, ecologia humana, bioregionalismo, projetos focados na escala do pedestre, participação comunitária e desenvolvimento sustentável. Os estudos sobre bairros ecológicos e ecovilas desenvolvidos nessa dissertação mostram que a infraestrutura verde é parte importante de sua estruturação, tendo papel fundamental no que diz respeito ao trato com os elementos naturais e à forma de trabalhar os processos urbanos em consonância com os processos da natureza, gerando respostas sempre positivas destes e obtendo as melhores performances dos dois sistemas, que trabalharão em conjunto.

A Vila Amélia mostrou-se ser uma área de grande potencial para aplicação dos questionamentos dessa pesquisa na medida em que, através da implantação de princípios ecológicos e de infraestrutura verde, adquire traços de uma ecocomunidade que muito se assemelha aos conceitos aqui estudados de ecovilas, com caráter mais vernacular, naturalista, de comunhão com a natureza e a sociedade, que surge da evolução de experiências e anseios comunitários, em área reclusa, na borda do espaço urbano da cidade de São Paulo. Já o bairro da Vila Amália, que constitui o restante da área pertencente à bacia hidrográfica do córrego do Índio, apresenta perfil mais urbano e características que Ihe permitem constituir um protótipo de bairro ecológico.

Com isso, fica expresso como a questão central desta pesquisa: o estudo do conceito de infraestrutura verde, apoiado nas teorias de desenho ambiental, ecologia urbana e ecologia da paisagem, analisando a sua aplicabilidade ao bairro da Vila Amélia e sua potencialidade como ferramenta para a constituição de uma ecocomunidade, pode contribuir para o avanço dos estudos científicos sobre comunidades ecológicas e o uso da infraestrutura verde para a sua formação, colaborando com o desenvolvimento de instrumentos que possam auxiliar a criação de cidades mais sustentáveis e resilientes. 


\section{REFERÊNCIAS BIBLIOGRÁFICAS}

AB'SABER, Aziz Nacib. Geomorfologia do Sítio Urbano de São Paulo. 1 ed. Cotia: Ateliê Editorial, 2007.

Um conceito de geomorfologia a serviço das pesquisas sobre o Quaternário. In: Geomorfologia, 18. São Paulo, IGEOG/ USP, 1969.

ADLER, Frederick R.; TANNER, Colby J. Ecossistemas urbanos: princípios ecológicos para o ambiente construído. São Paulo: Oficina de Textos, 2015.

AHERN, Jack F. From fail-safe to safe-to-fail: sustainability and resilience in the new urban world. Landscape Architecture \& Regional Planning: UMASS, v. 100, 2011.

- Green Infrastructure for Cities: The Spatial Dimension. In: NOVOTNY, V.; BROWN, P. (Org.). Cities of the Future: Towards Integrated Sustainable Water Landscape Management. Londres: IWA Publishing, 2007. pp. 267-283.

Greenways as Strategic Landscape Planning: theory and

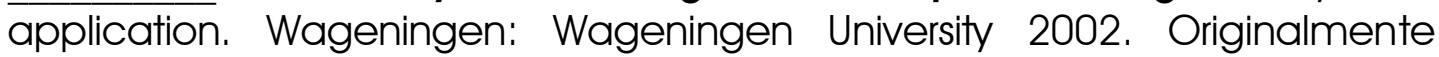
apresentado como tese de Pós-doutorado, Wageningen University, 2002.

. Greenways as a planning strategy. In: FABOS, J.; AHERN, J.(ed.). Greenways: the beginning of an international movement, p.131-55. Amsterdam: Elsevier, 1996.

AKINAGA, Patrícia. Urbanismo Ecológico: do princípio à ação: o caso de Itaquera, São Paulo, SP. 2014. 206 p. Tese (Doutorado em Arquitetura e Urbanismo) - Faculdade de Arquitetura e Urbanismo da Universidade de São Paulo, São Paulo 2014.

ALBERTI, Marina. Advances in Urban Ecology. New York: Springer, 2008.

ALBERTI, M.; MARZLUFF, J. M. Ecological resilience in urban ecosystems: Linking urban patterns to human and ecological functions. Urban Ecossystems, Kluwer Academic Publishers. Seattle: n. 7, p. 241-265, 2004. Disponível em:

$<$ http://www.springerlink.com/content/w2k2705776j6t84n/>. Acesso em 21 de jun. de 2014. 
AMERICAN SOCIETY OF LANDSCAPE ARCHITECTS. Landscape architect's handbook of professional practice. McLean, Va.: American Society of Landscape Architects, 1981.

ANDRADE, L. M. S. O conceito de Cidades-Jardins: uma adaptação para as cidades sustentáveis. Vitruvius. São Paulo: Romano Guerra Editora. 042.02, ano 04, nov 2003. Disponível em: <http://www.vitruvius.com.br/revistas/read/arquitextos/04.042/637>. Acesso em: 02 jan 2017.

ANDRADE, Daniel C.; ROMEIRO, Ademar R. Capital Natural, Serviços Ecossistêmicos e Sistema Econômico: rumo a uma Economia dos Ecossistemas. Texto para discussão 159, Instituto de Economia da Unicamp, 2009.

AQUINO, Gerdo. et al. Landscape Infrastructure: Case Studies by SWA. Basel: Birkhauser; London: Springer, 2011.

AUSTIN, Gari. Green Infrastructure for Landscape Planning: Integrating Human and Natural System. Oxford: Routledge, 2014.

BAGGETHUN, Erik G.; GROOT, Rudolf de; LOMAS, Pedro L.; MONTES, Carlos. The history of ecosystem services in economic theory and practice: From early notions to markets and payment schemes. Ecological Economics n.69, p.1209-1218, dec. 2009.

BANCO INTERAMERICANO DE DESENVOLVIMENTO. Sustentabilidade Urbana na América Latina e Caribe. Liderando o Desenvolvimento Sustentável nas Cidades. Washington: BID, 2001.

BARTON, H. Sustainable Communities: The Potential for Eco Neighbourhoods. London: Earthscan Publications, 2000.

BEATLEY, Timothy, Green Urbanism. Washington: Island Press, 2000 Green Cities of Europe. Washington: Island Press, 2012.

BENEDICT, Mark A.; MCMAHON, Edward T. Green Infrastructure: Linking Landscapes and Communities. Washington: Island Press, 2006.

Green Infrastructure: Smart Conservation for the 21st Century. Washington: Sprawl Watch Clearing House, 2002.

BERKES F.; COLDING, J.; FOLKE, C. (eds). Navigating Social-Ecological Systems. Building Resilience for Complexity and Change . Cambridge: Cambridge University Press, 2003. 
BOLUND, Per; HUNHAMMAR, Sven. Ecosystem services in urban areas. Ecological Economics, n. 29, p.293-301, 1999.

BRASIL. Ministério do Meio Ambiente. Convenção sobre diversidade biológica. Brasília, DF, 1994, artigo $2^{\circ}$.

BRUNDTLAND, G. H. (ed.). Our Common Future: The World Comission on Environment and Development. Oxford: Oxford Press, 1987.

CAPEL, H.; URTEGA, L. Las nuevas geografias. Barcelona: Salvat Ediciones Generales, 1991, 94p.

CAPRA, F. O Ponto de Mutação. São Paulo: Cultrix, 1982, 447p.

CHOAY. F. O urbanismo. Utopias e realidades, uma antologia. São Paulo: Editora perspectiva, 2005.

CIDADE, Lucia Cony F. A Questão Ambiental Urbana: Perspectivas de Análise. In: $V$ Encontro nacional da ANPUR, 1993, Belo Horizonte. Encruzilhadas das modernidades e planejamento. Belo Horizonte, v.5, p. 290-301.

COMMITTE ON ASSESSING AND VALUING THE SERVICES OF AQUATIC AND RELATED ECOSSYSTEMS. Valuing Ecossystems Services: Toward Better Environmental Decision Making. Washington: The National Academies Press, 2004.

CONSELHO DE AVALIAÇÃO ECOSSISTÊMICA DO MILÊNIO (CAEM). Ecossistemas e bem estar humano. Estrutura para uma avaliação. São Paulo: Editora SENAC São Paulo, 2005.

CORMIER, Nathaniel S.; PELLEGRINO, Paulo Renato Mesquita. Infraestrutura Verde: uma estratégia paisagística para a água urbana. Paisagem e ambiente: ensaios: FAUUSP. São Paulo, n. 25, p.127-142, 2008. Disponível em: <http://www.espiral.fau.usp.br/arquivos-artigos/2008-Nate\&Paulo.pdf $>$. Acesso em: 07 jun. 2014.

CONSTANZA, R. et. al. The Value of the World's ecossystem Services and Natural Capital. Nature 387, p. 253-260, mai. 1997.

COUTTS, Christopher. Green infrastructure and public health. New York: Routledge, 2016.

CZECHOWSKl, Daniel et al. (Org.). Revising Green Infrastructure: concepts between nature and design. New York: CRC Press, 2015. 
DAILY, Gretchen C. Nature's Services: Societal Dependence on Natural Ecosystems. Washington: Island Press, 1997.

DAILY, Gretchen C., ALEXANDER, Susan; EHRLICH, Paul R.; GOULDER, Larry; LUBCHENCO, Jane; MATSON, Pamela A.; MOONEY, Harold A.; POSTEL, Sandra; SCHNEIDER, Stephen H.; TILMAN, David; WOODWELL, George M. Ecosystem Services: Benefits Supplied to Human Societies by Natural Ecosystems. Issues in Ecology, No. 2, 1997.

DALE, Virginia $H$. at. al. Ecological Principles and Guidelines for Managing the Use of Land. Ecological Applications: ESA Reports. Washington, Vol. 10, N. 3, p. 639-670, 2000. Disponível em: <http://www.esa.org/policyStatements/LandUsePosition.pdf>. Acesso: em 10 jul. 2014.

D'AVILA, Márcio R. Bairros ecológicos na Alemanha. In: IV Encontro Nacional e II Encontro Latino-americano sobre Edificações e Comunidades Sustentáveis. 2007. Mato Grosso do Sul. Disponível em: < http://www.elecs2013.ufpr.br/wp-

content/uploads/anais/2007/2007_artigo_049.pdf >. Acesso em: 15 nov 2016.

DRAMSTAD, Wenche E.; OLSON, James D.; FORMAN, Richard T. T. Landscape Ecology Principles in Landscape Architecture and Land-Use Planning. Cambridge: Harvard University Graduate School of Design, Island Press and ASLA, 1996.

DUANY, A.; SPECK, J.; LYDON, M. The Smart Growth Manual. New York: Mc Graw Hill, 2010.

ECKBO, Garret. Landscape for living. New York: Architectural Record, 1950.

ELMQVIST, Thomas. Ecossystems, Ecossystems Services, and Social Systems in Urban Landscapes. Introduction. NIEMELÄ, Jari. (ed.) Urban Ecology. Patterns, Processes and Applications. Oxford: Oxford University Press, 2011.

FABIETTI, E.G; FABIETTI, G. What Is Sustainability? A Review of the Concept and Its Applications. 2013. Integrated reporting: concepts and cases that redefine corporate accountability. Springer, 2013. p. 21-40.

FARR, David. Urbanismo Sustentável: Desenho urbano com a Natureza. Porto Alegre: Bookman, 2013.

FERREIRA, Aurélio Buarque de Holanda, (1988). Dicionário Aurélio Básico da Língua Portuguesa. Rio de Janeiro: Nova Fronteira. 
FINDHORN FOUNDATION. Ecovillage. Disponível em: < https://www.findhorn.org/aboutus/>. Acesso em: 16 jan 2017.

FIREHOCK, Karen. A short history of the term green infrastructure and selected literature. Green Infrastructure Center, Charlotesville, 2010. Disponível em: <http://www.gicin.org/pdfs/Gl\%20history.pdf> Acessado em: 02 jun. 2004.

FORMAN, Richard T. T. Land Mosaics: The Ecology of Landscapes and Regions. Cambridge: Cambridge University Press, 1995.

- Urban Ecology: Science of cities. Cambridge: Cambridge University Press, 2014.

FORMAN, Richard T. T.; GODRON, Michel. Landscape Ecology. New York: John Wiley \& Sons, Inc., 1986.

FRANCO, Maria de Assunção Ribeiro. Desenho Ambiental: Introdução à Arquitetura da Paisagem com o Paradigma Ecológico. São Paulo: Annablume, 1997.

Paulo: Annablume, 2001.

Planejamento Ambiental para a Cidade Sustentável. São Infraestrutura verde em São Paulo: $O$ caso do corredor verde Ibirapuera - Villa Lobos. Revista Labverde: FAUUSP. São Paulo, n. 1, p. 134154, out. 2010.

GALLOPIN, G. Sostenibilidad y desarrollo Sostenible: un enfoque sistémico. Division de Desarollo Sostenible y Assentamientos Humanos, Chile, 2003.

GIOVANNONI, E.; FABIETII, G. What Is Sustainability? A Review of the Concept and Its Applications. Integrated reporting: concepts and cases that redefine corporate accountability. Springer, 2014. p. 21-40.

GIRLING, C.; KELLETT, R. Skinny Streets and Green eighborhoods. Washington: Island Press, 2005.

GIROT, Christophe. Four Trace in Landscape Architecture. In: CORNER, James, Recovering Landscape: Essays in Contemporary Landscape Theory. New York: Princeton Architectural Press, 1999.

$\begin{array}{lccc}\begin{array}{l}\text { GLOBAL ECOVILLAGE } \\ \text { sustainable }\end{array} & \begin{array}{c}\text { NETWORK. } \\ \text { world. }\end{array} & \begin{array}{c}\text { Connecting Communities } \\ \text { Disponível }\end{array} & \text { for a } \\ \text { em: }\end{array}$


$<$ http://gen.ecovillage.org/en/article/what-ecovillage >. Aceso em: 05 jan 2017.

GOLDMAN, Rebecca L. Ecosystem Services: How People Benefit from Nature. Environment, Science and Policy for Sustainable Development, sepoct. 2010. Disponível em: $<$ http://www.environmentmagazine.org/Archives/Back\%20lssues/SeptemberOctober\%202010/ecosystem-services-full.html>. Acesso em: Acesso em: 07/10/2016.

GONÇALVES, D. N. O futuro mais simples. Revista National geograpgic Brasil, p.135-143, Outubro 2011. Disponível em: < http://samesame.com.br/wp-content/uploads/201 1/1 1/NG139-134-135arrastado 1.pdf >. Acesso em 15 jan 2017.

GROOT, Rudolf S. de; WILSON, Matthew A.; BOUMANS, Roelof M. J. The Dynamics and Value of Ecosystem Services: Integrating Economic and Ecological Perspectives. A typology for the classification, description and valuation of ecosystem functions, goods and services. Ecological Economics, Special Issue, v. 41, p.393-408, 2002.

HANNES, E. O Parque da Juventude: Inserção Ambiental e Sustentabilidade. Revista Labverde: FAUUSP. São Paulo, n.8, p.140-156, jun. 2014.

. Espaços abertos e espaços livres: um estudo de tipologias. Revista Paisagem e Ambiente (FAU-USP), n.37, p. 121-144, 2016.

HANNES, E.; VIDOTIE, C.; CARAFFA, M. Conexão Esmeraldas: uma proposta de reformulação da paisagem dos bairros Jaçanã e Tremembé. In: BOUCINHAS, C. et. al. Libro del $2^{\circ}$ Encuentro Internacional La Formación Universitaria y la Dimensión Social del Profesional: a 46 años del Taller Total en la UNC. Córdoba: Universidad Nacional de Córdoba, 2017.

HARDI, P.; ZDAN, T. Assessing Sustainable Development: Principles in Practice. Winnipeg: International Institute for Sustainable Development, 1997.

HERZOG, Cecília P. Cidades para todos: (re)aprendendo a conviver com a natureza. Mauad x Inverde: Rio de Janeiro, 2013.

HERZOG, Cecília Polacow; ROSA, Lourdes Zunino. Infraestrutura verde: sustentabilidade e resiliência para a paisagem urbana. Revista LabVerde, FAUUSP, São Paulo, n.1, out. 2010, p.91-115. 
HOBBS, Richard J. The role of corridors in conservation: solution or bandwagon? Trends in Ecology \& Evolution, v.7, n. 11, p. 389-392, nov 1992.

HOUGH, Michael. City Form and Natural Process. New York: Routledge, 1989.

Design with city nature: an overview of some issues. In: PLATT, R. H., ROWNTREE, R. A. e MUICK, P. C. (Org.). The Ecological City. Amherst: The Univerisity of Massachusetts Press, 1994, p. 40-48.

JELLICOE, Geoffrey and Susan. The Landscape of Man. New York: Thames and Hudson Inc., 1987.

JONGMAN, Robert; KAMPHORST, Dana. Ecological Corridors in Land Use Planning and Development Policies. National approaches for ecological corridors of countries implementing the Pan-European Landscape and Biological Diversity Strategy. Netherlands: Concil of European publishing, 2002.

JOSS, S.; COWLEY, R.; TOMOZEIU, D. Towards the "ubiquitous eco-city": An analysis of the internationalization of eco-city policy and practice. Urban Research \& Practice, vol.6, p. 54-74, 2013.

KAMP, I. V.; LEIDELMEIJER, K.; MARSMAN, G.; HOLLANDER, A. Urban environmental quality and human well-being: Towards a conceptual framework and demarcation of concepts; a literature study. Elsevier: Landscape and urban planning, v.65, n. 1-2, p5-18. 2003. Disponível em: $<$ http://www.tlu.ee/ arro/Happy\%20Space\%20EKA\%202014/env\%20quality \%20and\%20wellbeing.pdf>. Acesso em: 02 jun. 2016.

KATES, R.W; PARRIS, T.M; LEISEROWITZ, A. A. What is sustainable development? Goals, indicators, values and practice. Environment: Science and Policy for Sustainable Development, v.47, n. 03, 2005, p. 8-21.

KIHSLINGER, Rebecca; WILKINSON, Jessica; McELFISH, James M. Biodiversity Corridors in Sustainable Urbanism: Urban Design with Nature. New York: John Wiley \& Sons, Inc., 2007.

KURATH, S. Designing Integral Urban Landscapes: On the End of Natureans the Beginning of Cultures. In: CZECHOWSKI, Daniel et al. (Org.). Revising Green Infrastructure: concepts between nature and design. New York: CRC Press, 2015.

LAURIE, Michael. An Introduction to Landscape Architecture. New York: Elsevier Science Publishing CO, 1978. 
LELÉ, S. M. Sustainable Development: A Critical Review. World Development, Great Britain, vol. 19, n06, 1991, p. 607-621.

LIKENS, G.E. The Ecosystem Approach: Its Use and Abuse. In: Kinne O. (ed) Excellence in ecology. Book 3. Oldendorf/ Luhe: International Ecology Institute, 1992.

LIMA, C. P. C. S. Sobre a paisagem. In: $4^{\circ}$ Congresso Internacional de Arquitetura Paisagística, 2016, São Paulo.

MANN, William A. Landscape Architecture: An Illustrated History in Timelines, Site Plans and Biography. New York: John Wiley and Sons, 1993.

MASCARÓ, J. L.; MASCARÓ L. E. A. R. Vegetação Urbana. Porto Alegre: UFRGS, Finep, 2002.

MCDONNELL, Mark J.; PICKET, S. T. A. (eds). Humans as Components of Ecosystems: Subtle Human Effects and the Ecology of Populated Areas. New York: Springer-Verlag, 1993.

MCDONNELL, Mark J. The history of Urban Ecology. In: NIEMELÄ, Jari. (ed.) Urban Ecology. Patterns, Processes and Applications. Oxford: Oxford University Press, 2011

MCHARG, lan L. Design with Nature. New York: Natural History Press, 1969.

MEBRATU, D. Sustainability and sustainable development: historical and conceptual review. Environmental Impact Assessment Review, v. 18, n.6, p.493-520, 1998.

MELL, lan. Green Infrastructure: concepts, perceptions and its use in planning: Developing Green Infrastructure planning in the UK, Europe and North America. Liverpool: Lambert Academic Publishing, 2012.

MINISTÉRIO DO MEIO AMBIENTE. IBAMA / MMA. Ecossistemas Brasileiros: Mata Atlântica. Disponível em: <http://www.ibama.gov.br/fauna/> . Acesso em 15 de Setembro de 2008, 19:12.

MOSTAFAVI, Mohsen; DOHERTY, Gareth; (Org.). Urbanismo Ecológico. Barcelona: Ed. Gustavo Gili, 2014.

NATIONAL CAPITAL PLANNING COMISSION. The SW Ecodistrict. A vision plan for a more sustainable future. Washington: NCPC, 2013. 
NAVEH, Z.; LIEBERMAN, A. S. Landscape Ecology - Theory and Application. New York: Springer-Verlag, 1984.

NEWTON, Norman T. Design on the land: the development of landscape architecture. Massachusetts, The Belknap Press of Harvard University Press, 1971.

NIEMELÄ, Jari. (ed.) Urban Ecology. Patterns, Processes and Applications. Oxford: Oxford University Press, 2011.

NUCCl, João Carlos. Origem e desenvolvimento da ecologia da paisagem. Revista Geografar, Faculdade de Geografia da Universidade Estadual do Paraná, Curitiba, v. 2, n. 1, jan-junho/2007, p. 77-79. Disponível em:

http://www.geoplan.net.br/material_didatico/Nucci_Eco_Paisagem_2009.p df. Acesso em: 01 jun. 2016.

$\mathrm{NUCCl}$, J. C. et.al. Método para o Mapeamento da Qualidade Ambiental Urbana. Anais do XI Simpósio Brasileiro de Geografia Física Aplicada, 2005 - USP. p. 393-403.

ODUM, Eugene P. Fundamentos da Ecologia. Lisboa: Fundação Calouste Gulbenkian, 2001.

OLMSTED, F.; BEVERIDGE, C.; SCHUYLER, D. Creating Central Park, $1857-$ 1861. Baltimore: Johns Hopkins University Press, 1983.

ORTEGA, Julia Martin; FERRIER Robert C.; GORDON, Lain J,; KHAN Shahbaz. Water Ecosystem Services, A Global Perspective. Cambridge: Cambridge University Press, 2015.

ORGANIZAÇÃO DAS NAÇÕES UNIDAS NO BRASIL. Objetivos do Desenvolvimento do Milênio. 17 Objetivos para transformar nosso mundo. 2015. Disponível em: < https://nacoesunidas.org/pos2015/agenda2030/>. Acesso em: 03 dez 2016.

PANZINI, Franco. Projetar a natureza, Arquitetura da paisagem e dos jardins desde as origens até a época contemporânea. São Paulo: Editora SENAC São Paulo, 2013.

PELLEGRINO, Paulo; AHERN, Jack; BECKER, Newton. Green infrastructure: Performance, Appearance, Economy, and Working Method. In: CZECHOWSKI, Daniel et al. (Org.). Revising Green Infrastructure: concepts between nature and design. New York: CRC Press, 2015.

PICKET, S.T.A., PARKER, V. T., FIEDLER, P. L. The new paradigm in ecology: Implications for conservation biology above the species level. In: FIEDLER, 
P. L.; JAIN, S. K. (eds.) Conservation Biology. New York: Chapman and Hall, 1992.

PICKET, S. T. A.; CADENASSO, M. L. Landscape ecology: Spatial Heterogeneity in Ecologycal Systems. Science, vo. 269, p. 331-334, jul. 1995.

PICKET, S. T. A.; CADENASSO, M. L.; GROVE, J. M. Resilient Cities: meaning, models, and metaphor for integrating the ecological, socio-economic, and planning realms. Landscape and urban Planning, n.69, p.369-384, 2004.

PICKET, Steward. et al. Urban Ecological Systems: Linking Terrestrial, Ecological, Physical, and Socioeconomic Components of Metropolitan Areas. Annual Review: Ecology, Evolution and Systematics. Vol. 32, p. 127$157,2001$.

PINTÉR, L.; HARDI, P.; MARTINUZZI, A.; HALL, J. Bellagio Stamp: Principles for sustainability assessment and measurement. Elsevier, Jounal of Ecological indicators, n. 17, 2012, p. 20-28.

PREFEITURA DE SÃO PAULO. Geosampa: Mapa Cartográfico da Cidade de São Paulo. São Paulo, 2016. 1 mapa. Escalas variam.

RIDDELL, C. The Findhorn Community: Creating a Human Identity for the 21 st Century. Findhorn, Findhorn Press, 1990.

ROCHA, Carlos Frederico. BERGALLO, Helena G.; SLUYS, Monique Van; ALVES, Maria Alice S.; JENKINS, Clinton. Corredores Ecológicos e Conservação de Biodiversidade: Um Estudo de Caso na Mata Atlântica. In: ROCHA et. Al. Biologia da Conservação. São Paulo: Rima, 2006.

https://www.researchgate.net/profile/Helena De Bergallo/publication/21677

5744_Corredores_ecolgicos_e_conservao_da_biodiversidade_um_estudo_ de_caso_na_Mata_AtIntica/links/56132df00̄8aēa34aa929c505.pdf

RONCKEN, P.A.; STREMKE, S.; PULSELLI, R. M. Landscape Machines: Designerly Concept and Framework for an Evolving Discourse on Living System Design. In: CZECHOWSKI, Daniel et al. (Org.). Revising Green Infrastructure: concepts between nature and design. New York: CRC Press, 2015.

ROSELAND, M. Dimensions of the eco-city. Cities, vol. 14, n. 4, p. 197-202, 1997.

ROUSE, David C.; OSSA, Ignacio F. Bunster. Green Infrastructure: A Landscape Approach. Chicago: American Planning Association, 2013. 
RUANO, M. Ecourbanism: Sustainable Human Settlements. 60 Case Studies. Barcelona: Gustavo Gill, 1999.

SAHTOURIS, Elisabet. Gaia: do caos ao cosmos. São Paulo: Interação, 1991.

SÃO PAULO (Município). Secretaria Municipal de Desenvolvimento Urbano: Subprefeitura Butantã. Zoneamento da Cidade de São Paulo. Disponível em:<http://www.prefeitura.sp.gov.br/cidade/secretarias/desenvolvimento_ur bano/legislacao/planos_regionais/index.php?p=1759>. Acesso em: 16 jul. 2015.

Plano Diretor Estratégico. Disponível em: <http://gestaourbana.prefeitura.sp.gov.br/plano-diretor/>. Acesso em: 16 jun. 2014.

. Secretaria Municipal do Verde e Meio Ambiente / Secretaria Municipal de Planejamento Urbano. Atlas Ambiental do Município de São Paulo. São Paulo: SVMA, 2004.

- Secretaria Municipal do Verde e Meio Ambiente / Secretaria Municipal de Planejamento Urbano. Vegetação Significativa do Município de São Paulo. São Paulo: SVMA, 1988.

SÃO PAULO (Estado). Secretaria Estadual do Meio Ambiente. Parque Alberto Loefgren - Horto Florestal. São Paulo: SMA, 2016. Disponível em: < http://hortoflorestal.sp.gov.br/conheca-o-horto/>. Acesso em: 28 out 2016.

- Companhia Ambiental do Estado de São Paulo. Relação de áreas contaminadas. São Paulo, 2015. Disponível em: < http://areascontaminadas.cetesb.sp.gov.br/relacao-de-areas-

contaminadas/>. Acesso em 10 out 2016.

- Departamento de Águas e Energia Elétrica. Piscinões cumprem papel das várzeas ocupadas desordenadamente. São Paulo, 2015. Disponível em: < http://www.daee.sp.gov.br/index.php?option =com_content\&view =article\&i $\mathrm{d}=60$ :piscinoes-home\&catid=38: piscinoes > . Acesso em 05 out 2016.

SARTORI, S; LATRÔNICO, F; CAMPOS, L. M. S. Sustentabilidade e desenvolvimento sustentável: uma taxonomia no campo da literatura. Revista Ambiente e sociedade: ANPPAS. São Paulo, v. XVII n. 1, 2014, p. 1-22.

SCHMIDT, Edgar et al. Método para o mapeamento da qualidade ambiental urbana. In: Anais do XI Simpósio Brasileiro de Geografia Física Aplicada - 05 a 09 de setembro de 2005 - Universidade de São Paulo. p. 
393-404.

Disponível

em:

http://www.geografia.ufpr.br/laboratorios/labs/arquivos/SCHMIDT\%20et\%20al \%20(2005).pdf. Acesso em: 27/1 1/2007.

SCHUTZER, José Guilherme. Cidade e meio ambiente: A Apropriação do Relevo no Desenho Ambiental Urbano. São Paulo: Editora da Universidade de São Paulo, 2012.

Dispersão urbana e apropriação do relevo na macrometrópole de São Paulo. 2012. 328 p. Tese (Doutorado em Geografia Física) - Faculdade de Filosofia, Letras e Ciências Humanas da Universidade de São Paulo, São Paulo, 2012.

SERRÃO, Adriana Veríssimo, (2011). Filosofia da paisagem. Uma antologia. Lisboa: Centro de Filosofia da Universidade de Lisboa.

SCHUTZER, J. G. et al. A Preservação de Nascentes em áreas urbanas consolidadas: Microáreas de Proteção Ambiental como instrumento urbanístico para um zoneamento ambiental do solo urbano. In: III Seminário Nacional APPURBANA, 2014, Belém. A Dimensão Ambiental da Cidade. Belém, v.3, p. 1-20.

SPIRN, Anne Whiston. The Granite Garden: Urban Nature and Human Design. New York: Basic Books, 1984.

Ecological Urbanism: a framework for the design of resiliente Cities. In: PICKET, S. T. A.; CANDENASSO, M. L.; MCGRATH, B. P. Resilience in Ecology and Urban Design. New York: Springer Verlag, 2013.

SWAFFIELD, Simon. Theory in Landscape Architecture. A reader. Philadelphia: University of Pennsylvania Press, 2002.

US REGIONAL ASSOCIATION OF THE INTERNATIONAL ASSOCIATION FOR LANDSCAPE ECOLOGY. What is Landscape Ecology? - Richard Forman. Disponível em: < http://www.usiale.org/what-landscapeecology/forman>. Acesso em: 07/10/2016.

VITOUSEK, Peter M.; MOONEY, Harold A.; LUBCHENCO, Jane; MELILLO, Jerry M. Human Domination of Erath's Ecossystems. Science, New Series, vol. 277, n. 5325, p.494-499, jul. 1997.

WALDHEIM, Charles (Org.). The Landscape Urbanism Reader. New York: Princeton Architectural Press, 2006.

WILLIAMSON, S. Karen. Growing with Green Infrastructure. Doylestown: Heritage Conservancy, 2003. 
WORLD ENVIRONMENT COMMISSION ON DEVELOPMENT. Report of the World Commisson on Environment and development: Our Common Future. Oxford and New York: Oxford University Press, 1987.

WU, Jianguo. Making the Case for Landscape Ecology: An Effective Approach to Urban Sustainability. Landscape Journal, v. 27, n. 1, p. 41-50, 2008.

WU, Jianguo, HE, Chunyang; HUANG, Ganlin; YU, Deyoung. Urban Landscape Ecology: Past, Present and Future. In: NIEMELÄ, Jari. (ed.) Urban Ecology. Patterns, Processes and Applications. Oxford: Oxford University Press, 2011.

WU, Jianguo, HOBBS, Richard. Key issues and research priorities in landscape ecology: An idiosyncratic Synthesis. Landscape Ecology, n. 17, p.355-365, 2002. 